\title{
REVISTA
}

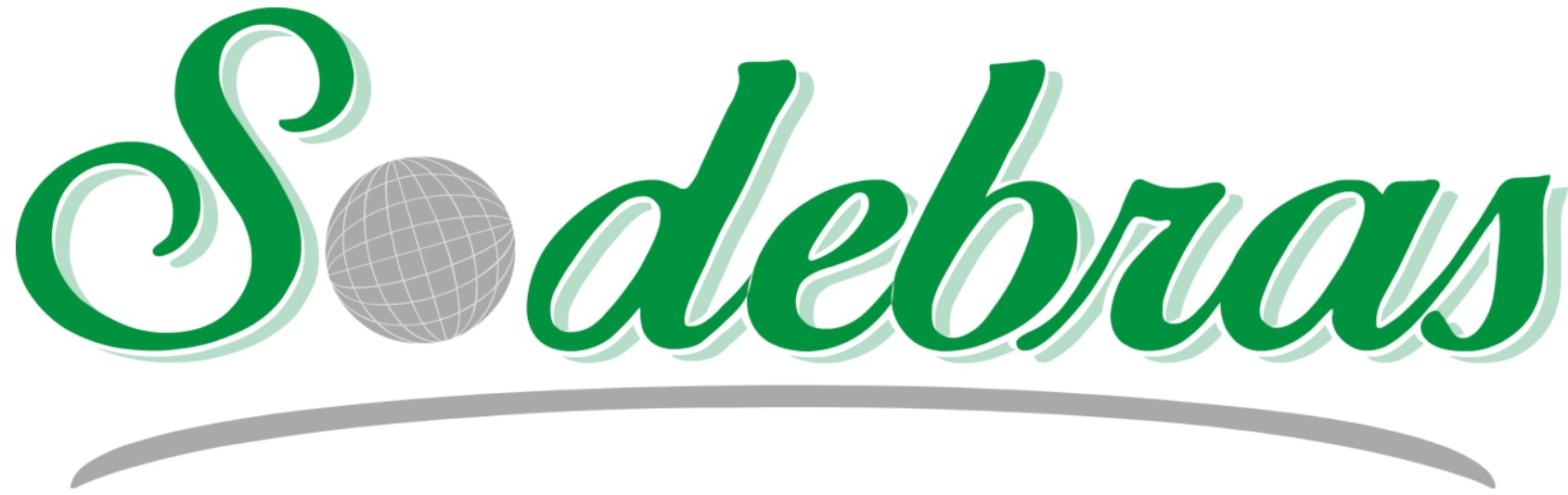

SOLUÇÕES PARA O DESENVOLVIMENTO DO PAÍS 


\title{
ARTIGOS PUBLICADOS
}

\author{
PUBLICAÇÃO MENSAL \\ Nesta edição
}

PERCEPÇÃO DOS STEKAHOLDERS SOBRE A IMPLANTAÇÃO DE NOVO MODELO PEDAGÓGICO EM UMA INSTIITUIÇÃO DE ENSINO PROFISSIONAL NO ESTADO DE MINAS GERAIS

PERCEPTION OF STEKAHOLDERS ABOUT THE IMPLEMENTATION OF A NEW PEDAGOGICAL MODEL IN A VOCATIONAL EDUCATIONAL INSTITUTION IN THE STATE OF MINAS GERAIS - Adriana

Damasceno; Fernando Oliveira De Araujo; Chrystyane Abreu

A DERIVA TRANSDISCIPLINAR DA PSICOLOGIA ENQUANTO PRÁTICA SOCIAL

THE TRANSDISCIPLINARY DRIFT OF PSYCHOLOGY AS A SOCIAL PRATICE - Guilherme Augusto Souza Prado; Marcos Antonio De Sousa Rodrigues Moura; Elaine Soares De Freitas Leitão; Willian Dos Santos Souza

ELABORAÇÃO DE E-BOOK FACILITADOR PARA A REDAÇÃO DE PATENTES

ELABORATION OF FACILITATOR E-BOOK FOR PATENT WRITING - Leandro Rafael De Abreu; Vanessa Ishikawa Rasoto; Paulo Rogério Pinto Rodrigues; Cláudia Crisostimo

PANORAMA HISTÓRICO-CONCEITUAL DA ISO 9001: UMA ANÁLISE A PARTIR DE SUAS REVISÕES

ISO 9001 HISTORICAL-CONCEPTUAL OVERVIEW: AN ANALYSIS FROM ITS REVIEWS - Marina Muniz

Do Couto Soares; Iale Carine Silva De Oliveira; Sueli Menelau

ECONOMIA CRIATIVA E SUSTENTABILIDADE NA GRANDE CUIABÁ/MT

CREATIVE ECONOMY AND SUSTAINABILITY IN GRANDE CUIABÁ/MT - Antônio Ananias Mota Júnior;

Raquel Martins Fernandes; Rodrigo Ribeiro De Oliveira; Maria Geni Pereira Bilio

EPIDEMIOLOGICAL PROFILE OF MAXILLOFACIAL TRAUMA IN A TEACHING HOSPITAL IN BRAZIL Rodrigo Lemos Alves; Izabelly Linhares Ponte Brito; Vicente De Paulo Teixeira Pinto; Francisco Cesar

Barroso Barbosa

UM MODELO DE INFRAESTRUTURA DE MICROSSERVIÇOS PARA ALGORITMOS DE AGRUPAMENTO DE FLUXOS CONTÍNUOS DE DADOS

A MICROSERVICE INFRASTRUCTURE MODEL FOR STREAMING DATA CLUSTERING ALGORITHMS -

Giuliano Oliveira De Macedo; Jonathan Andrade Silva; Dionisio Machado Leite Filho

DESENVOLVIMENTO DE ATIVIDADE EXPERIMENTAL UTILIZANDO INDICADOR ÁCIDO-BASE

EXTRAÍDO DE FLORES DA PAISAGEM COTIDIANA

DEVELOPMENT OF EXPERIMENTAL ACTIVITY USING ACID-BASE INDICATOR EXTRACTED FROM DAILY LANDSCAPE FLOWERS - Carlos Da Silva Lopes; Maria De Fátima Vaz Xavier; Lara Oliveira Paiva

Ribeiro; Karen De Vasconcelos Feitosa

GERAÇÃO COMPARTILHADA DE ENERGIA ELÉTRICA ATRAVÉS DE CONSÓRCIOS E COOPERATIVAS

SHARED GENERATION OF ELECTRICITY THROUGH CONSORTIUMS AND COOPERATIVES - Allana De Moura Netto; Jair Urbanetz Junior; Américo Vicente Teixeira Leite 
MODELING AND SIMULATION OF A STOCK BANK IN BATTERIES WITH PHOTOVOLTAIC GENERATOR Márcio Augusto Teles Da Cruz; João Batista Dias

MODELAGEM, SIMULAÇÃO E IMPLANTAÇÃO DE SISTEMA FOTOVOLTAICO PARA ALIMENTAÇÃO DE DISPOSITIVO DE MONITORAMENTO REMOTO DE DRENAGEM ELÉTRICA

MODELING, SIMULATION AND IMPLEMENTATION OF A PHOTOVOLTAIC SYSTEM FOR POWERING REMOTE MONITORING DEVICE OF ELECTRIC DRAINAGE - Márcio Augusto Teles Da Cruz; João Batista Dias

DESENVOLVIMENTO DE FERRAMENTA PARA OTIMIZAÇÃO DO MÉTODO DE REDUÇÃO DE RISCOS CONTRATUAIS EM EMPREITADAS NA CONSTRUÇÃO CIVIL

DEVELOPMENT OF TOOL FOR OPTIMIZING THE METHOD OF REDUCING CONTRACTUAL RISKS IN CIVIL CONSTRUCTION CONTRACTORS - Mônica Miranda De Carvalho; Ana Regina Santos De Camargo;

Adriana De Paula Lacerda Santos

OTIMIZAÇÃO DE FROTA DE EMPILHADEIRA: UM ESTUDO DE CASO

FORKLIFT FLEET OPTIMIZATION: A CASE STUDY - Mariana Og Gallo Esteves; Nilo Antonio De Souza Sampaio; José Glênio Medeiros De Barros; Antonio Henriques De Araujo Junior

REDUÇÃO DE PERDAS ATRAVÉS DA DIGITALIZAÇÃO DE PROCESSOS NO CONTEXTO DA INDÚSTRIA 4.0

WASTE REDUCTION THROUGH DIGITALIZATION OF PROCESSES IN THE CONTEXT OF INDUSTRY 4.0

- Marcos Ronaldo Albertin; Jusicleiton Santos Pereira; Heráclito Lopes Jaguaribe Pontes

AVALIAÇÃO DE INDICADORES EMPRESARIAIS ATRAVÉS DA ANÁLISE FATORIAL EXPLOTARÓRIA E TEORIA DE RESPOSTA AO ITEM

EVALUATION OF BUSINESS INDICATORS USING EXPLORATORY FACTOR ANALYSIS AND ITEM RESPONSE THEORY - Marcos Ronaldo Albertin; Marcos Charles Pinheiro Baltazar; Heráclito Lopes Jaguaribe Pontes 


\section{Área: Interdisciplinar}

\begin{tabular}{|l|l|}
\hline $9-13$ & PERCEPÇÃO DOS STEKAHOLDERS SOBRE A IMPLANTAÇÃO DE NOVO \\
& MODELO PEDAGÓGICO EM UMA INSTITUIÇÃO DE ENSINO PROFISSIONAL NO \\
& ESTADO DE MINAS GERAIS \\
& $\begin{array}{l}\text { PERCEPTION OF STEKAHOLDERS ABOUT THE IMPLEMENTATION OF A NEW } \\
\text { PEDAGOGICAL MODEL IN A VOCATIONAL EDUCATIONAL INSTITUTION IN } \\
\text { THE STATE OF MINAS GERAIS } \\
\text { Adriana Damasceno; Fernando Oliveira De Araujo; Chrystyane Abreu }\end{array}$ \\
\hline $9-18$ & $\begin{array}{l}\text { A DERIVA TRANSDISCIPLINAR DA PSICOLOGIA ENQUANTO PRÁTICA SOCIAL } \\
\text { THE TRANSDISCIPLINARY DRIFT OF PSYCHOLOGY AS A SOCIAL PRATICE } \\
\text { Guilherme Augusto Souza Prado; Marcos Antonio De Sousa Rodrigues Moura; Elaine } \\
\text { Soares De Freitas Leitão; Willian Dos Santos Souza }\end{array}$ \\
\hline
\end{tabular}




\title{
Revista SODEBRAS - Volume 15 $\mathrm{N}^{\circ} 178$ - OUTUBRO/ 2020
}

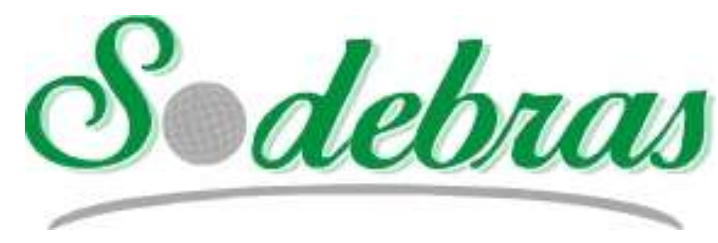

\section{PERCEPÇÃO DOS STEKAHOLDERS SOBRE A IMPLANTAÇÃO DE NOVO MODELO PEDAGÓGICO EM UMA INSTITUIÇÃO DE ENSINO PROFISSIONAL NO ESTADO DE MINAS GERAIS}

\section{PERCEPTION OF STEKAHOLDERS ABOUT THE IMPLEMENTATION OF A NEW PEDAGOGICAL MODEL IN A VOCATIONAL EDUCATIONAL INSTITUTION IN THE STATE OF MINAS GERAIS}

\author{
ADRIANA DAMASCENO ${ }^{1}$; FERNANDO OLIVEIRA DE ARAUJO²; CHRYSTYANE ABREU ${ }^{3}$ \\ $1 ; 2$ - UFF; 3 - CEFET/RJ \\ adrianadcba@gmail.com,fernandoaraujo@id.uff.br,chrystyane.abreu@cefet-rj.br
}

\begin{abstract}
Resumo - Mudanças organizacionais precisam ser acomodadas junto a distintas partes interessadas. Assim, identificar a percepção de distintos stakeholders acerca da implantação de novo modelo pedagógico em uma instituição de ensino profissionalizante é uma questão a ser apreciada. Para tanto, foi realizada pesquisa bibliométrica para compreensão de achados teóricos sobre o tema e pesquisa descritiva a partir da coleta de dados, através da aplicação de questionário, em 05 unidades distintas da referida instituição. A amostra totalizou 37 docentes e 06 supervisores, sendo possível verificar em que medida suas percepções complementam ou contrapõem os achados teóricos. As percepções dos stakeholders apresentaram apoio ao projeto, a partir da concordância com o modelo pedagógico implantado, que permitiram ganhos consideráveis em seus processos de trabalho, além de melhora no desenvolvimento de competências $e$ habilidades dos alunos. $O$ estudo possibilitou ainda $a$ identificação dos principais métodos e ferramentas utilizados em sala de aula, com objetivo de contribuir com a formação profissional do alunado.
\end{abstract}

Palavras-chave: Educação Profissional. Metodologias Ativas. Gestão de Mudanças.

Abstract - Organizational changes need to be accommodated with different stakeholders. Thus, identifying the perception of different stakeholders about the implementation of a new pedagogical model in a vocational education institution is an issue to be appreciated. For this purpose, a bibliometric research was carried out to understand theoretical findings on the topic and descriptive research based on data collection, through the application of a questionnaire, in 05 different units of that institution. The sample totaled 37 professors and 06 supervisors, being possible to verify to what extent their perceptions complement or oppose the theoretical findings. The perceptions of stakeholders showed support for the project, based on the agreement with the implemented pedagogical model, which allowed considerable gains in their work processes, in addition to improving the development of students' skills and abilities. The study also made it possible to identify the main methods and tools used in the classroom, in order to contribute to the student's professional training.

Keywords: Professional Education. Active Methodologies. Change Management.

\section{INTRODUÇÃO}

Com as constantes mudanças inerentes aos ambientes organizacionais e a necessidade de as empresas se adequarem, visando ao atendimento de suas demandas específicas, a gestão tradicional de projetos organizacionais que tinha como principais indicadores orçamento, cronograma, escopo e qualidade, passa também a considerar o gerenciamento de benefícios, priorizando o atendimento das reais necessidades do cliente final (KERZNER, 2016).

Para minimizar as resistências às mudanças, bem como alcançar as intenções almejadas, na elaboração do projeto, uma das estratégias fundamentais é associar os objetivos do projeto aos dos stakeholders (CARLI, 2015). Por isso, a necessidade de identificar e entender a percepção dos stakeholders sobre o projeto a ser implantado e os impactos que podem trazer aos seus objetivos (RIBEIRO \& ARAUJO, 2018).

Segundo Carli (2015), é importante conhecer os grupos envolvidos no projeto e a expectativa de valor de cada um, de maneira segmentada, considerando a necessidade de aceitação, motivação e engajamento.

Esse pressuposto compõe também a gestão de mudança de um projeto, pois quanto mais alinhados os stakeholders estiverem, em relação aos resultados propostos pelo projeto e os seus objetivos pessoais e profissionais, menor a resistência às mudanças e maior aderência aos novos processos necessários ao projeto implantado.

Em uma organização de educação profissional o alinhamento entre os objetivos dos stakeholders e suas dinâmicas comportamentais tem sido percebido como condição para se manter no mercado, motivando e engajando seus stakeholders nos projetos para adequação dos modelos pedagógicos adotados, com vista a ampliar os conceitos e as abordagens do aprendizado, considerando além dos conceitos técnicos as experiências do cotidiano de cada indivíduo.

Com isso, as ações profissionais possuem um saber que pode ser identificado a partir da reflexão na ação. $O$ profissional faz reflexões em relação ao modo como transita pelas situações cotidianas e suas práticas e de modo consciente analisando essas ações, pode encontrar novas 
soluções para problemas de aprendizagem, o que o conduz a elaborar novas estratégias de atuação, através do exercício do pensamento crítico em novas situações que vão surgindo em seu dia a dia (FONTANA; FAVERO, 2013).

Diante desse cenário, a instituição de ensino pesquisada, implementa um projeto para novo modelo pedagógico baseado em metodologias ativas para o processo de ensino aprendizagem.

Com isso, a pesquisa ora apresentada tem como principal objetivo responder as seguintes questões: Quais as distintas percepções dos stakeholders, envolvidos em um projeto de implantação de novo modelo pedagógico? Quais os impactos em seus comportamentos? E ainda como ocorreu à condução da gestão da mudança nos processos pedagógicos das unidades de ensino analisadas?

A pesquisa realizada é relevante por possibilitar a compreensão de como alguns dos stakeholders chave de um projeto, apresentam suas manifestações de apoio, resistência e/ou neutralidade, em relação a implantação do projeto, os impactos em seus comportamentos a partir da implantação e as ações realizadas pela instituição na gestão da mudança.

Além disso, a pesquisa pode ser inspiradora, para outras instituições de ensino profissional, em relação a mudança de paradigma sobre a estrutura curricular oferecida, no sentido de aderir um modelo pedagógico fundamentado nas metodologias ativas de ensino aprendizagem, com o propósito de melhorar as ações contributivas para a formação dos alunos.

\section{REVISÃO DA LITERATURA}

\section{1 - Modelo Pedagógico}

O modelo pedagógico proposto pela instituição de ensino pesquisada nesse trabalho, propõe que o processo de ensino seja realizado, utilizando as metodologias ativas para garantir o lugar do aluno, como principal agente da construção do seu saber, apoiado e conduzido pelo professor/orientador.

A partir dessa proposta, é relevante uma reflexão preliminar acerca do que são metodologias ativas de ensino. Para isso, Araújo (2015) defende que metodologias ativas não possui um único precursor, pois foi constituída entre os séculos XVIII e XIX, utilizando-se dos conceitos primários da biologia e psicologia, sendo admitida na educação, mais precisamente no contexto escolar, a partir da segunda metade do século XIX, início do século XX, e disseminada com maior amplitude através do movimento New school, que surgiu na Inglaterra e contou com teóricos escolanovistas como W. James, J. Dewey, A. Ferrière e E. Claparède.

Segundo Shön (2000), as metodologias ativas consideram a aprendizagem a partir da ação-reflexão-ação, como estímulo no processo de ensino-aprendizagem, para incentivar o aluno ao envolvimento mais efetivo na busca pelo conhecimento.

Uma das bases conceituais da metodologia ativa é o conceito da ação-reflexão-ação, que está como núcleo da aprendizagem, pois é construído a partir do fazer e analisar o próprio fazer, instituindo a relação com a prática profissional adotada no mercado de trabalho, além de utilizar de forma produtiva, as experiências que o aluno traz do seu contexto social a favor do desenvolvimento das competências necessárias para cada profissão (SENAC/DN, 2015).
Com isso, o processo de aprendizagem considera as diferentes perspectivas, que podem ser usadas para a produção de mudanças e transformação social, e maior tolerância à diversidade, como defende Lara et al. (2019).

Mas a metodologia que torna o aluno protagonista na busca pelo conhecimento, não deve descartar a experiência prática do professor, que para conduzir o processo de ensino de forma eficaz, precisa promover condições para que o aluno consiga perceber a relação da teoria com a prática, adotada no ambiente fora da sala de aula.

Nesse sentido, Ruskovaara e Pinkala (2014) ressalta a importância da experiência de mercado que o docente traz, em disciplinas que dependem do conhecimento do ambiente organizacional, para criar um cenário favorável a aplicação de metodologias que proporcionem a relação da teoria à prática.

Contreras e Menoyo (2019) observam que o professor precisa ser capaz de utilizar as metodologias contribuintes com o desenvolvimento de habilidades e competências dos alunos, considerando a relação desses indivíduos com a sociedade onde atuarão enquanto profissionais. Isso poderá fazer a diferença no perfil desses profissionais, que ingressam no mercado com uma visão mais ampla e integrada do papel das organizações no ambiente em que estão inseridas.

Para Da Costa (2016), uma das formas apontadas na metodologia ativa de ensino e que pode ser utilizada pelo professor para desenvolver as competências necessárias em seus alunos, é a proposição de situações problema, que refletem o contexto real das organizações, a serem solucionados pelos discentes de maneira colaborativa entre seus pares. Mas a autora ressalta que para atividades como essa, proposta no modelo pedagógico, o professor precisa ainda, conhecer previamente as características dos seus alunos, incluindo o contexto sociocultural e de desenvolvimento, podendo assim, propor atividades que sejam estimulantes e que proporcionem a percepção do alunado sobre sua capacidade de resolver situações, relacionando a teoria com a prática, absorvendo de maneira mais eficaz o conteúdo apresentado.

Solucionar os problemas propostos através de um estudo de caso, por exemplo, também é uma forma de aprender fazendo, desenvolvendo o fazer profissional, destacado por Rocha (2017) como atividade para colocar em prática o resultado de pesquisas realizadas pelos alunos, em busca de informações relevantes, sobre o conteúdo abordado, para junto com suas percepções de vida, promover a construção do seu saber.

Rocha (2017) observa também que tanto para o docente quanto para os alunos, a aprendizagem deve ser um processo contínuo e que proporcione o prazer pela investigação de conteúdo para formar o conhecimento e quando $\mathrm{o}$ aluno se percebe protagonista dessa ação e responsável pela sua formação, consegue também se perceber enquanto profissional no mercado de trabalho.

$\mathrm{O}$ uso de metodologias ativas é analisado por Ruskovaara e Pihkala (2014), como instrumento eficaz no processo de aprendizagem de disciplinas desenvolvidas para incentivar o perfil empreendedor dos alunos, integrando a teoria e a prática, através de atividades em diferentes ambientes e melhorando a percepção do aluno sobre sua relação com o mercado. Para os autores, os métodos de ensino mais tradicionais tendem a limitar o ambiente de aprendizagem, a sala de aula. 
Cavenett (2017) aponta ainda que a mudança na metodologia de ensino, com foco no aluno enquanto o agente mais importante de sua formação, ocorre também em função da demanda latente do mercado de trabalho, por profissionais com competências e habilidades que precisam ser desenvolvidas junto com a aprendizagem do conteúdo técnico. Nesse sentido, o aluno é incentivado pelo professor a utilizar as habilidades formadas em seu contexto de vida, para busca e melhor compreensão do conteúdo proposto, além de desenvolver competências que serão aplicadas no ambiente de trabalho, com maior facilidade de adaptação, atendendo as expectativas das organizações, que anseiam por profissionais capazes de aliar o conhecimento técnico ao comportamento adequado à sua função.

Palumbo e Manna (2019) afirma que para as instituições de ensino implantarem mudanças necessárias para atender ao mercado, precisam desenvolver a capacidade de absorver as pressões dos Stakeholders e conduzir o processo de transição de forma eficaz.

Contudo, qual a percepção de Stakeholders envolvidos na implantação de um modelo pedagógico com essa proposta? Silva et al. (2019) em sua pesquisa sobre a inclusão de uma disciplina, no curso de medicina da Universidade do Pará, onde houve a estratégia de utilizar as metodologias ativas, conclui que, os Stakeholders envolvidos, sejam alunos ou professores, ainda se sentem inseguros com o método. A pesquisa revela também que os alunos sabem do seu protagonismo no desenvolvimento das competências, porém ainda não entendem que o professor deve atuar como facilitador do processo de aprendizagem e não como ator principal.

Por outro lado, Gioiosa e Kinkela (2018) afirmam que o uso de modelo pedagógico com as metodologias ativas pode ter menor resistência do Stakeholders envolvidos quando o processo é disseminado e observado, enquanto aliado para o desenvolvimento das competências exigidas pelos empregadores ao buscar um profissional. E ainda, que o conforto dos alunos e absorção do conteúdo técnico, quando são submetidos a uma ou mais ferramentas de metodologias ativas, melhora a cada dia, tornando-os mais preparados para o exercício da profissão.

Nesse sentindo, Salam et al. (2019) corrobora que a percepção dos Stakeholders envolvidos em projetos desenvolvidos nas instituições de ensino, utilizando a prestação de serviços à comunidade, como ferramenta para colocar em prática a teoria abordada em sala de aula, faz com que o envolvimento dos alunos seja mais efetivo e proporcione novos sentidos para a aprendizagem, maior engajamento e desenvolvimentos de competências necessárias a cada profissão.

Salam et al. (2019), destaca também, que os alunos submetidos ao uso de metodologias ativas, como por exemplo, participar de projetos desenvolvidos para a comunidade, através da prestação de serviço com propósito social, colocando em prática a teoria abordada em determinas disciplinas, reconhecem que a oportunidade é benéfica ao processo de aprendizagem e se envolvem mais nesse processo, pois reconhecem ainda que a experiência da prestação de serviço, é uma possibilidade real de aprendizado.

\section{METODOLOGIA}

O estudo foi realizado em cinco unidades, distribuídas por cinco regionais do estado de Minas Gerais, onde a instituição de ensino profissionalizante pesquisada está localizada, com foco em dois stakeholders, docentes e supervisores pedagógicos, envolvidos no projeto para implantação do novo modelo pedagógico, dos cursos de aprendizagem profissional, técnicos e livres, oferecidos pela instituição.

Para coleta de dados através das fontes primárias, foi elaborado questionário para pesquisa online a ser aplicado através da SurveyMonkey, por se tratar de amostra com dispersão geográfica, distribuída em cinco regiões do Estado de Minas Gerais, em que atua a instituição pesquisada.

A aplicação do questionário foi realizada em duas etapas, a saber: 1) contato prévio com os responsáveis pelas unidades da instituição pesquisada; 2) apresentação da pesquisa e envio do link, gerado na ferramenta SurveyMonkey, o questionário para coleta das respostas dos sujeitos pesquisados.

Neste estudo, foi realizado pré-teste com um docente e um supervisor pedagógico, de uma das unidades selecionadas para realização da pesquisa. Essa ação contribuiu na identificação de possíveis melhorias a serem realizadas no questionário.

Os dois participantes da pesquisa, um de cada conjunto de respondentes, expressaram não sentir dificuldades para responder o questionário.

No questionário destinado aos supervisores pedagógicos foi sugerida a alteração da questão relacionada a mudança nos critérios de avaliação dos docentes, tornando-a aberta para permitir a descrição dos critérios pelos respondentes.

Foram aplicados dois modelos de questionários, um para os docentes e outro para os supervisores pedagógicos. Os dois tipos de respondentes eram colaboradores da instituição no momento em que responderam à pesquisa de maneira espontânea, no período de 06 de outubro de 2019 a 08 de dezembro de 2019.

Como critério para seleção dos respondentes, foi utilizado $100 \%$ dos docentes e supervisores pedagógicos, atuantes nos cursos técnicos, oferecidos em cinco unidades, uma de cada regional da instituição pesquisada, no estado de Minas Gerais.

Participaram da pesquisa 37 docentes e 6 supervisores pedagógicos, das unidades selecionadas, resultando no percentual de respondentes, em relação ao total de profissionais, conforme sistematizado na Tabela 1 .

Tabela 1 - Percentual de respondentes por total de profissionais

\begin{tabular}{|c|c|c|}
\hline Regional & $\begin{array}{l}\% \text { dos docentes } \\
\text { respondentes atuantes nos } \\
\text { cursos técnicos }\end{array}$ & $\begin{array}{l}\% \text { dos supervisores pedagógicos } \\
\text { respondentes atuantes nos cursos } \\
\text { técnicos }\end{array}$ \\
\hline Capital & $40 \%$ & $0 \%$ \\
\hline Norte/Leste & $100 \%$ & $100 \%$ \\
\hline Sul & $100 \%$ & $100 \%$ \\
\hline Triângulo & $100 \%$ & $100 \%$ \\
\hline Zona da Mata & $100 \%$ & $67 \%$ \\
\hline Total & $\mathbf{8 8 \%}$ & $73 \%$ \\
\hline
\end{tabular}

Após a coleta os dados podem ser tratados em 3 etapas: seleção, etapa em que ocorre a análise detalhada das respostas obtidas; a codificação, etapa da categorização dos dados, conforme critérios estabelecidos na pesquisa; e tabulação, etapa em que se disposição os dados em tabelas, para avaliação da relação entre os dados e cálculos estatísticos e apresentação dos resultados. 


\section{RESULTADOS E DISCUSSÃO}

O projeto implantado na instituição de ensino pesquisada propõe uma metodologia de ensino/ aprendizagem, que considera como uma de suas principais características, a utilização das experiências de cada indivíduo em seu contexto de vida, pessoal e profissional, isso vale tanto para o docente, quanto para o aluno.

\section{1 - Percepção dos docentes}

Em 2016 a unidade estadual de Minas Gerais implantou o projeto em suas cinco regionais, sendo que $62 \%$ dos respondentes participaram da implantação do projeto.

Dos participantes na implantação do projeto, $92 \%$ responderam à questão relacionada ao recebimento de treinamento sobre o modelo pedagógico, antes da implantação do projeto, na unidade em que atuam como docente. As respostas estão ilustradas na Figura 1, onde é possível observar o percentual de satisfação dos docentes em relação ao treinamento realizado.

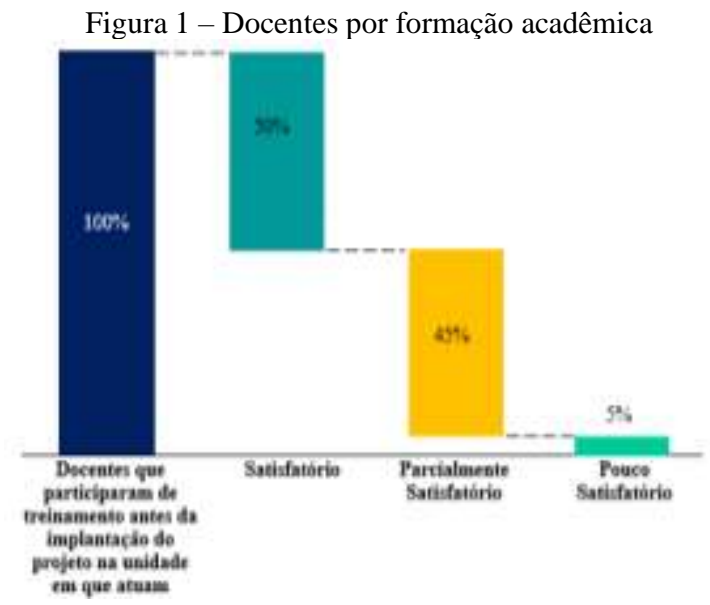

Fonte: Os autores.

Em relação à percepção dos docentes sobre o modelo pedagógico proposto no projeto, $57 \%$ concordam totalmente, conforme ilustra na Figura 2, o que pode sugerir apoio ao modelo implantado.

Figura 2 - Percepção dos docentes sobre o modelo pedagógico

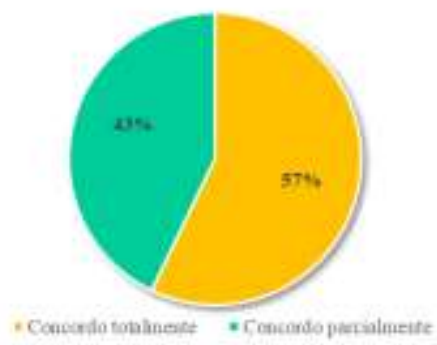

Fonte: Os autores.

Uma das características do modelo pedagógico é a constante necessidade de adequação da didática que $\mathrm{o}$ docente utiliza em sala de aula. A adequação ocorre com frequência, em função do perfil de cada turma, conhecimentos e habilidades a serem desenvolvidas nos alunos, de acordo com a proposta de cada disciplina.

Diante disso, os respondentes da pesquisa, avaliaram quais as principais mudanças ocorridas na didática adotada em sala de aula, a partir da implantação do projeto na instituição. Os resultados obtidos nessa questão encontramse ilustrados na Figura 3.

Figura 3 - Principais métodos utilizados na didática de ensino a partir do projeto

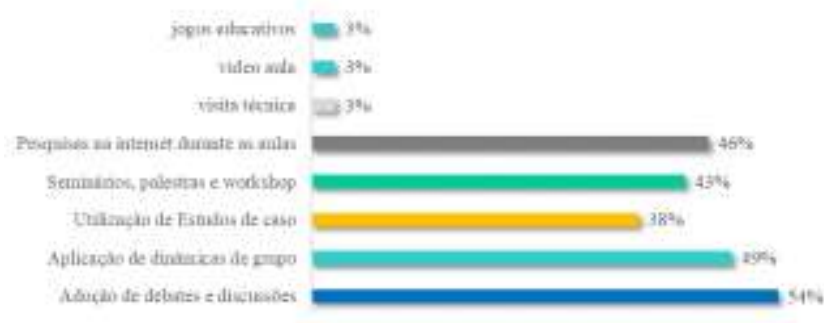

Fonte: Os autores.

Como resultado, percebe-se um equilíbrio na utilização de alguns dos métodos de ensino/ aprendizagem pelos docentes.

\section{2 - Percepção dos docentes}

O papel do supervisor pedagógico na implantação do projeto, está diretamente ligado a orientação dos docentes sobre o novo modelo desenvolvido, incentivando a adoção das práticas propostas.

Para isso, desde a contratação dos docentes, treinamento, acompanhamento e avaliação da didática de ensino adotada em sala de aula, consideram as metodologias ativas propostas no projeto implantado, como fator direcionador da prática pedagógica na instituição pesquisada.

A partir dessa perspectiva, este tópico tem o objetivo de identificar o perfil dos supervisores pedagógicos, a percepção sobre o modelo pedagógico adotado pela instituição e em relação as principais mudanças ocorridas na forma de avaliação dos docentes, a partir da implantação do projeto.

Antes da implantação do projeto, $50 \%$ dos respondentes participaram de treinamento sobre o modelo pedagógico, na unidade em que atuam como supervisores. As respostas estão ilustradas na Figura 4, onde é possível observar também o percentual de satisfação dos supervisores em relação ao treinamento recebido.

Figura 4 - Participação no treinamento antes da implantação do projeto

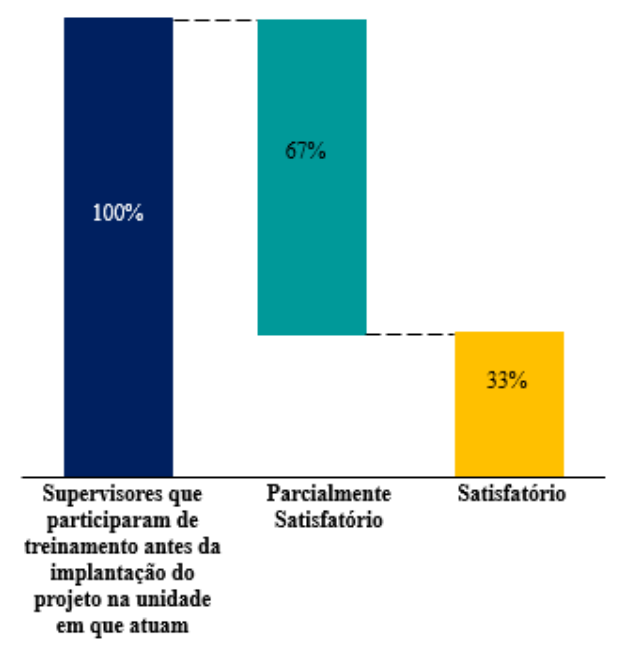

Fonte: Os autores. 
Outra questão relevante respondida pelos supervisores é sobre o modelo pedagógico proposto, resultando em $83 \%$ de concordância em relação ao projeto implantado, conforme apresentado na Figura 5.

Figura 5 - Percepção dos supervisores em relação ao modelo pedagógico

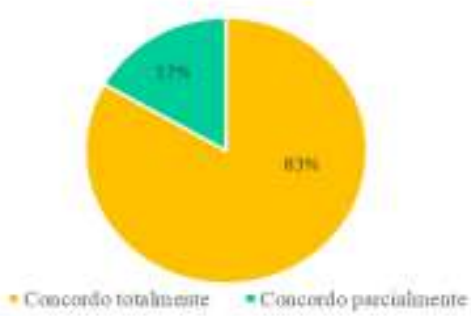

Fonte: Os autores.

A concordância com o modelo pedagógico proposto pela instituição pode impactar a forma como o supervisor conduz a equipe em relação a adoção das práticas de ensino, abordadas em sala de aula a partir da implantação do projeto.

O acompanhamento do corpo docente de cada unidade, pelo supervisor, passa ainda pela promoção de ambiente favorável ao compartilhamento das práticas pedagógicas, adotadas pelos os docentes, gerando a troca de experiências e enriquecimento do conhecimento sobre o tema.

Além do acompanhamento das práticas pedagógicas adotadas pelos docentes, troca de experiências, dentre outras questões, as reuniões pedagógicas também permitem a identificação dos principais métodos, utilizadas pelos docentes em sala de aula a partir da implantação do modelo pedagógico.

Nesse sentido, a Figura 6 apresenta os principais métodos utilizados pelos docentes, sendo possível observar que na percepção dos supervisores, diferentes métodos são empregados na mesma proporção pelos docentes.

Figura 6 - Principais métodos utilizados pelos docentes, na percepção dos supervisores pedagógicos
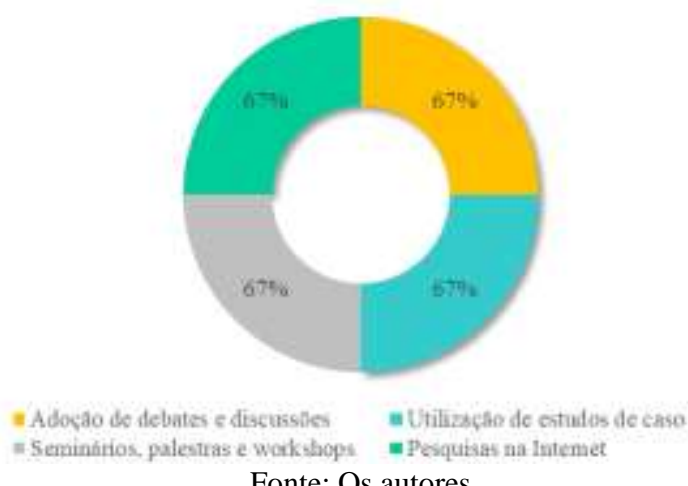

Fonte: Os autores.

A utilização de variados métodos para disseminação de conteúdo pelos docentes é apontada também por Ruskovaara e Pihkala (2014) como fator que pode proporcionar aos alunos a interação com a realidade do mercado, estimulando o perfil empreendedor, exigido pelas organizações. A adoção das práticas pedagógicas baseadas em metodologias ativas, requer do supervisor pedagógico, atenção especial na avaliação dos docentes, em função da identificação do perfil profissional que atendam alguns critérios imprescindíveis, para aplicação das diretrizes propostas no projeto implantado.

Alguns dos supervisores participantes da pesquisa relataram suas percepções sobre as mudanças nos critérios de avaliação utilizados, após a implantação do projeto, conforme descrito na Tabela 2, onde os respondentes estão identificados pelas siglas S01, S02, S03 e S04.

Tabela 2 - Relato dos supervisores sobre critérios de avaliação

\begin{tabular}{c|l|l|l}
\hline Identificação & \multicolumn{1}{|c|}{ Mudanças ocorridas } & \multicolumn{1}{|c}{ Relato } \\
\hline S01 & $\begin{array}{l}\text { Sobre a periodicidade das } \\
\text { avaliações. }\end{array}$ & $\begin{array}{l}\text { "O modelo de avaliação tradicional foi alterado, hoje } \\
\text { os docentes entendem que a avaliação acontece a todo } \\
\text { momento e de diversas formas" }\end{array}$ \\
\hline S02 & $\begin{array}{l}\text { Em relação a experiência prática na } \\
\text { ára da disciplina ministrada, e } \\
\text { conhecimento em metodologias } \\
\text { ativas. }\end{array}$ & $\begin{array}{l}\text { "Avaliamos se o docente tem o perfil profissional de } \\
\text { acordo com os cursos em que atuará, com experiência } \\
\text { prática na área e conhecimento em metodologias } \\
\text { ativas." }\end{array}$ \\
\hline S03 & $\begin{array}{l}\text { Necessidade de avaliar o processo } \\
\text { adotado pelo docente, para } \\
\text { organizar sua atuação em sala de } \\
\text { aula. }\end{array}$ & $\begin{array}{l}\text { "A avaliação é pautada no desempenho do docente } \\
\text { considerando: planejamento, procedimentos avaliativos } \\
\text { aplicados, gestão de sala de aula e prática } \\
\text { pedagógica." }\end{array}$ \\
\hline S04 & $\begin{array}{l}\text { Alinhamento de expectativas com o } \\
\text { docente. }\end{array}$ & $\begin{array}{l}\text { "O projeto trouxe a necessidade de modificar a forma } \\
\text { de avaliação, incluindo também o feedback mais } \\
\text { constante e eficiente". }\end{array}$ \\
\hline
\end{tabular}

Fonte: Os autores.

A partir dos resultados destacados na pesquisa empírica, cabe ressaltar que a implantação do novo modelo pedagógico, gerou uma série de alterações nos processos pedagógicos adotados pela instituição, devido a busca por adequação do ambiente acadêmico, para preparação de profissionais melhor preparados para o mercado de trabalho.

A percepção dos respondentes, docentes e supervisores pedagógicos pode ser utilizada como fator contributivo para avaliação dos resultados do projeto implantado, considerando o do modelo pedagógico adotado e a identificação das necessidades de melhoria nos processos pedagógicos da instituição pesquisada.

O resumo dos principais pontos abordados na pesquisa, encontra-se na Figura 7, permitindo a observação dos achados mais relevantes.

Figura 7 - Principais pontos percebidos pelos respondentes

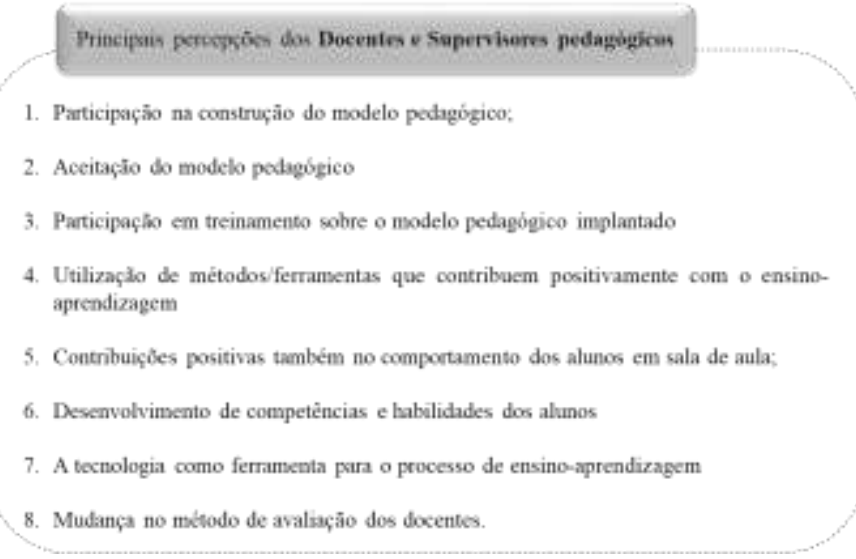

Fonte: Os autores.

A maioria dos respondentes concorda com o modelo pedagógico proposto. Essa concordância contribui para a influência que exercerão sobre sua implantação e resultados 
projetados (YANG et al., 2009; ZAMCOPÉ et al., 2012; OFFENBEEK \& Vos, 2015; AALTONEN e KUJALA, 2016; ESKEROD \& LARSEN, 2017).

O fato de concordarem com o projeto, também faz com que as chances de os resultados serem positivos aumente, uma vez que esses stakeholders tem a missão de aplicar o modelo com os alunos da instituição pesquisada, garantindo o sucesso do projeto.

Em relação as limitações da pesquisa, é importante ressaltar que não contempla os alunos da instituição, por ser focada em avaliar a implantação do projeto, investigando as percepções dos stakeholders em relação as mudanças ocorridas a partir desse movimento, que foi executado em três anos.

Diante disso a instituição optou por finalizar as turmas em andamento, que adotavam a antiga proposta pedagógica e utilizar o novo modelo somente para as novas turmas, iniciadas após a implantação do projeto, Diante disso, os alunos matriculados nos cursos técnicos em 2019, período de aplicação da pesquisa, não possuem informações necessárias para comparação entre os modelos, bem como a geração de percepções em relação as mudanças ocorridas a partir da implantação do projeto

\section{CONCLUSÃO}

O objetivo desta pesquisa consiste em identificar a percepção de distintos stakeholders, acerca da implantação de novo modelo pedagógico. Para isso, foi realizada pesquisa em uma instituição de ensino profissionalizante, utilizando como amostra dois dos stakeholders, envolvidos no projeto. Como resultado foi possível identificar o perfil dos stakeholders selecionados; quais impactos em seus comportamentos a partir da implantação do novo modelo pedagógico proposto pela instituição pesquisada; manifestações de resistência e/ ou de apoio dos stakeholders, em relação a implantação do projeto; as principais mudanças nos métodos utilizados para ensinoaprendizagem pelos docentes em sala de aula e método adotado para gestão da mudança.

Sobre o perfil dos docentes o resultado da pesquisa apontou, que além da formação acadêmica em diferentes áreas do conhecimento e que podem ser complementares no exercício do ensino-aprendizagem. Já a prática pedagógica utilizada pelos docentes em sala de aula, teve como principal alteração, a inclusão de métodos para ensinoaprendizagem que como: pesquisa sobre o conteúdo na internet durante as aulas, estudos de caso, debates e discussões em grupos e preparação de workshops, dentre outras sugeridas pelo modelo proposto.

Em relação aos supervisores pedagógicos, o que mais se destacou foi $67 \%$ terem acompanhado a implantação do projeto, as mudanças ocorridas e resultados obtidos, manifestando concordância com o modelo pedagógico adotado.

Por fim, observou-se ainda nos resultados da pesquisa, que em relação a gestão da mudança, foi realizado treinamento com os stakeholders, antes da implantação do projeto. Contudo, não foram identificadas outras estratégias para gestão da mudança e que poderiam contribuir com o aumento do índice de concordância com o modelo pedagógico proposto e sucesso do projeto.

É importante citar ainda que, mais ações para identificação das percepções sobre o projeto e dificuldades encontradas pelos stakeholders, podem garantir à instituição pesquisada conhecimento mais amplo sobre os desafios futuros em relação ao modelo pedagógico.

\section{REFERÊNCIAS}

AALTONEN, K.; KUJALA, J. Towards an improved understanding of project stakeholder landscapes. International Journal of Project Management. v.34 (8), p. 1537-1552, 2016.

ARAÚJO, J. C. S. Fundamentos da metodologia de ensino ativa (1890-1931). $37^{\mathrm{a}}$ Reunião Nacional da ANPED. Florianópolis: UFSC, 2015.

CARLI, E. Gestão de Mudanças aplicada a projetos: Ferramentas de Change Management para Unir PMO e CMO. Rio de Janeiro: Brasport, 2015.

CAVENETT, S. Authentically enhancing the learning and development environment. Australasian Journal of Engineering Education. v.22, n.1, p. 39-53, 2017.

CONTERAS, M. F. S.; MENOYO, M. A. Place-based education: An approach for a sustainable curriculum in higher education. Bordon Revista de Pedagogia. v.71, n.2, p. $155-174,2019$.

DA COSTA LOBATO, C. Estratégias metodológicas de ensino-aprendizagem na educação a distância: um estudo de caso no instituto federal do Amapá. Universidade Federal Rural do Rio de Janeiro Biblioteca Central / Seção de Processamento Técnico. f.125, 2016.

ESKEROD, P.; LARSEN, T. Advancing project stakeholder analysis by the concept 'shadows of the context. International Journal of Project Management. v. 36 (1), p. 161-169, 2018.

FONTANA, M. J.; FÁVERO, A. A. Professor reflexivo: uma integração entre teoria e prática. Revista de Educação do IDEAU, v. 8, n. 17, jan./jun. 2013.

GIOIOSA, M. E.; KINKELA, K. Classroom exercises with technology and communication skills: students' perceptions. Journal of International Education in Business. v. 12, n.1, p.2-13, 2018.

KERZNER, H. Gestão de projetos: as melhores práticas [recurso eletrônico] / Harold Kerzner; tradução: Christiane de Brito; revisão técnica: Fábio Giordani. 3. ed. Porto Alegre: Bookman, 2016.

LARA EMO et al. O professor nas metodologias ativas e as nuances entre ensinar e aprender: desafios e possibilidades. Interface comunicação, saúde e educação. v.23, 2019. Disponível em: 〈https://www.interface.org.br〉. Acesso em: 26. Jun.2019.

OFFENBEEK, M. A. G. V.; VOS, J. F. J. An integrative framework for managing project issues across stakeholder groups. International Journal of Project Management. v. 34 (1) p. 44-57, 2016.

PALUMBO, R.; MANNA, R. Making educational organizations able to change: a literature review. International Journal of Educational Management. v.33, n.4, p. 734-752, 2019.

RIBEIRO, P.; ARAUJO, F. Inovação na indústria farmacêutica brasileira: Confrontação perceptual entre 
regulados e agentes Reguladores. Revista SODEBRAS [on line], v. 13, n. 150, p. 83-89, 2018. Disponível em: http://www.sodebras.com.br/edicoes/N150.pdf. Acesso em jul./2020.

ROCHA, M. O. Interdisciplinaridade e aprendizagem significativa no contexto da educação profissional e tecnológica do estado do Paraná. Dissertação (Mestrado em Educação). São Paulo: PUC-SP: 2017.

RUSKOVAARA, E.; PINKALA, T. Entrepreneurship Education in Schools: Empirical Evidence on the Teacher's Role. The Journal of Educational Research. v.0, p. 1-14, 2014.

SALAN et al. Technology integration in service-learning pedagogy: A holistic framework. Telematics and Informatics. v.38, p. 257-273, 2019.

SCHÖN, D. A. Educando o profissional reflexivo: um novo design para o ensino e a aprendizagem / Donald A. Schön; trad. Roberto Cataldo Costa. Porto Alegre: Artes Médicas Sul, 2000.

SENAC. DN. Concepções e princípios. Rio de Janeiro: 2015. 34 p. (Coleção de Documentos Técnicos do Modelo Pedagógico Senac, n.1).

SILVA et al. Percepção do Estudante de Medicina sobre a Inserção da Radiologia no Ensino de Graduação com Uso de Metodologias Ativas. Revista Brasileira de Educação Médica. v. 43, n.2, p. 95-105, 2019.

YANG, C. \& SU, Y. The relationship between benefits of ERP systems implementation and its impacts on firm performance of SCM. Journal of Enterprise Information Management, v. 22 (6) p. 722-752, 2009.

ZAMCOPÉ et al. Construction of a model for corporate sustainability assessment: A case study in the textile industry. Gestão e Produção. v.19(2), p. 303-321, 2012.

\section{COPYRIGHT}

Direitos autorais: Os autores são os únicos responsáveis pelo material incluído no artigo.

Submetido em: $24 / 08 / 2020$

Aprovado em: 29/09/2020 


\title{
A DERIVA TRANSDISCIPLINAR DA PSICOLOGIA ENQUANTO PRÁTICA SOCIAL
}

\section{THE TRANSDISCIPLINARY DRIFT OF PSYCHOLOGY AS A SOCIAL PRATICE}

\author{
GUILHERME AUGUSTO SOUZA PRADO ${ }^{1}$; MARCOS ANTONIO DE SOUSA RODRIGUES MOURA ${ }^{1}$; \\ ELAINE SOARES DE FREITAS LEITÃ ${ }^{1}$; WILLIAN DOS SANTOS SOUZA ${ }^{1}$ \\ 1 - UNIVERSIDADE FEDERAL DO DELTA DO PARNAÍBA \\ guispra@gmail.com; marcosantoniosrmoura@gmail.com; elainesoares30@hotmail.com; szawillian@gmail.com
}

\begin{abstract}
Resumo - O presente trabalho propõe uma caracterização da Psicologia como prática social e como campo de dispersão desde os estudos e tensionamentos realizados por Foucault, Deleuze e Guattari no que tocam a complexidade do campo transdisciplinar da produção de subjetivação. Realizamos uma revisão bibliográfica buscando os atravessamentos e relações de transversalização entre clínica e política nas práticas psicológicas e na proposição de estratégias locais e singulares, que se ocupam da construção de novas maneiras de viver e da produção da saúde.
\end{abstract}

Palavras-chave: Transdisciplinaridade. Transversalidade. Psicologia. Prática Social. Produção de Subjetividades.

\begin{abstract}
The present essay proposes a characterization of Psychology as a social practice in relation of transdisciplinarity since the studies realized by Foucault, Deleuze and Guattari on the complexity of the transdisciplinary field of subjectivity production. In this context, we conducted a bibliographic review focused on the theme of cross-cutting and transversalization relations between clinic and politics in the context of psychological practices and in proposing local and singular strategies that are concerned with the construction of new ways of living and the production of health.
\end{abstract}

Keywords: Transdisciplinarity. Transversality. Psychology. Social Practice. Production of Subjectivities.

\section{INTRODUÇÃO}

Nos últimos anos no Brasil, temos acompanhado um aumento progressivo das publicações que articulam a Psicologia, enquanto campo de dispersão e prática social, à filosofia da diferença, notadamente ao pensamento de Foucault, Deleuze e Guattari (CAVALCANTE et al., 2016; GOMES et al., 2019; HUR, 2013). Tais atravessamentos indicam uma reafirmação da Psicologia como uma prática concomitantemente social e analítica (GUATTARI, 2002) e como um campo em contínua dispersão, não unificável em torno de um objeto ou método unificados.

Ao se dedicar à constituição do saber psicológico, Garcia-Roza (1977) destaca que a história deste saber é descontínua e não-progressiva, o que tem algumas consequências para a organização de seu campo disciplinar. A primeira delas é que não se pode falar em continuidade e progresso a não ser no interior de cada teoria ou sistema psicológico. Segundo, assim como a positividade da psicologia prescinde do aval de cientificidade, a emergência da noção de comportamento deve ser destituída do posto mítico que marcaria a passagem da era pré-científica para a ciência psicológica.

Portanto, à medida em que forma um conjunto aditivo e não uma unidade teórica estrutural sistemática e homogênea, deveríamos tratar de Psicologias, que em suas variadas histórias compõem um espaço de dispersão constituído mais por diferenças que por identidades. Logo, assumimos que, embora a Psicologia tenha uma história (institucional) relativamente curta, ela tem um passado (enquanto campo de dispersão) inegavelmente longo e que seu caráter de dispersão é positivamente constitutivo, dela e de seus procedimentos.

Com isso, nos dispomos a tematizar a deriva transdisciplinar da Psicologia como prática social e como campo de dispersão a partir das suas intercessões, suas perturbações desviantes e criadoras com o pensamento de Foucault, Deleuze e Guattari e as ressonâncias da noção de transversalidade nela.

\section{METODOLOGIA}

Para o presente ensaio, utilizamos o método bibliográfico, que se caracteriza como uma pesquisa autônoma que se utiliza de dados e informações de obras já existentes e auxilia na análise e interpretação de um tema específico dando corpo a um campo de problematizações a fim de servir de base para os outros tipos de estudos.

Assim, o presente ensaio de revisão bibliográfica e abordagem qualitativa teve como preocupação fundamental explorar a partir das discussões de autores como Foucault, Deleuze e Guattari impasses e pontos de convergência em torno da proposição de uma Psicologia em relação de transdisciplinaridade com campos externos a ela.

\section{RESULTADOS E DISCUSSÃO}

\section{1 - Complexidade e transdisciplinaridade}

O campo disciplinar da Psicologia enquanto ciência moderna visa lidar com um terreno complexo - que trataremos aqui, como plano de produção de subjetividades entendido como complicado, o qual se tenta simplificar através de recursos como atomização e quantificação ou abordagens que recorrem a metáforas fenomenológicas, funcionalistas ou estruturalistas, dentre outras recortes da multiplicidade (FIGUEIREDO, 1991). Reduzir um terreno complexo a caracteres elementares de acordo com os 
princípios fragmentação do conhecimento e dicotomização da realidade em ideias claras e distintas (como sujeito-objeto, parte-todo, razão-emoção, simples-complexo, unidademultiplicidade, particular-universal, etc.) é tido como um ganho metódico na busca pela verdade desde Descartes (1973).

O método de produção de verdade cartesiana tem como instrumento a dúvida hiperbólica e como garantia o status normativo da lógica matematizada - salvaguarda um conhecimento tido como desinteressado. Ele propicia a submissão do corpo e da natureza ao conhecimento e ao controle numa busca supostamente asséptica, que se esquiva da determinação material do sujeito que conhece (FOUCAULT, 2000) em prol de neutralizar as interferências do subjetivo ou da consideração do probabilístico, fontes de ideias confusas.

O que é tido como confusão e se torna alvo de simplificações, contudo, é a própria complexidade constituinte da realidade e do plano de produção de subjetividades. Nesse âmbito, a noção de transdisciplinaridade emerge frente ao questionamento e à inviabilização da dicotomização fragmentária da matéria sistematicamente em um mesmo nível.

A noção de transdisciplinaridade emerge como interferência, entre distintos planos organizativos da realidade e ou entre suas categorias operativas, que faz necessária outra ordem de respostas aos problemas das ciências exatas. Ao mudarmos os modos de ler uma situação ou problema, acionamos outras dimensões que levam a formas distintas de resposta.

Assim, quando a Física Quântica comprova que o quanton é composto simultaneamente de ondas e corpúsculos, dois aspectos estruturantes e inconciliáveis da Física Clássica (de matriz newtoniana), esta entra em crise e leva a tiracolo os axiomas da identidade ( $\mathrm{X}$ é igual a $\mathrm{X}$ ), da não contradição ( $\mathrm{X}$ não é não-X) e do terceiro excluído (não há $\mathrm{Y}$, que seja ao mesmo tempo, $\mathrm{X}$ e não-X). Tais axiomas ordenam sistematicamente num mesmo nível as fronteiras da matéria e funcionando na lógica de disjunção exclusiva ou...ou .

Frente a tal crise, em 1931, Gödel propõe o teorema da indecidibilidade, onde traz que uma proposição indecidível (como a especificação de um quanton) dentro de um sistema lógico formalizado complexo põe em xeque a consistência do sistema. Numa situação dessas de inconsistência, Morin (1996) argumenta que, não encontrando a prova em si, um sistema pode recorrer a outro metassistema para prová-lo como a Física Clássica requer a Física Quântica. Contudo, quando esse metassistema auxiliar mostra suas falhas, buscar a verdade torna-se um jogo aberto e indefinido no qual a própria lógica se torna insuficiente e as divisões disciplinares, obsoletas, requerendo uma abordagem transdisciplinar que comportem situações e respostas, indecidíveis ou contraditórios (NICOLESCU, 2002).

Por outro lado, a fragmentação das dificuldades metódicas em quantas partes sejam necessárias para resolvêlas é base para a divisão disciplinar do conhecimento e seus efeitos práticos são desastrosos, como podemos averiguar com a disfuncional disjunção da Psicologia, enquanto prática social, da ética relegada ao campo da filosofia aplicada. Se a simplificação inerente ao princípio da fragmentação acarreta na descontextualização de toda ação, inclusive da de produção de saber, as grades curriculares fazem das disciplinas esquemas que bloqueiam o fluxo das relações existentes em uma realidade complexa.

Embora emerjam de diferentes contextos, a complexidade, enquanto modo de inteligibilidade e a transdisciplinaridade se articulam de maneira complementar. O pensamento complexo sistematizado por Morin (2007) parte da dinamicidade e instabilidade das relações entre partes e todo. Ele se expressa, portanto, com o paradoxo de que o todo é maior e menor do que a soma das partes, uma vez que os efeitos de realidade do conjunto são irredutíveis à soma de suas parcelas, assim como a totalização pretendida ao final do processo de conhecimento desconsidera ou obnubila as qualidades das partes. A esse respeito, Deleuze e Guattari (2011) falam do todo ao lado das partes, evidenciando o caráter não unificante e não totalizante da relação entre todo e partes, e um tipo de comunicação que se dá por transversais e preserva a diferença em cada dimensão.

Para Morin (2007), o paradoxo do uno e do múltiplo implica na íntima relação entre o todo e as partes e na interdependência entre eles e entre os diferentes sistemas que fragmentam e escamoteiam a realidade complexa do mundo. A natureza ativa da realidade se expressa na interligação dinâmica entre todas as coisas, que são no máximo parte de um contínuo. O exemplo paradigmático da árvore, cuja partição em raízes, tronco e folhas é estranha à realidade de seus processos vitais, é análoga à da biologia do organismo humano em sistemas funcionais, insuficiente para explicar seus processos de saúde-adoecimento.

Desta maneira, toda e qualquer parte é compreensível apenas desde as inter-relações que estabelece com a dinâmica do todo e a multiplicidade de elementos e sistemas interagentes expressa um recorte específico dos diversos níveis da realidade. Logo, assumir o desafio da multiplicidade abre a possibilidade de reordenamento dos distintos níveis e sistemas de apreensão e intervenção junto à realidade.

Piaget (1972) tematiza tal reordenamento nos termos de interdisciplinaridade e transdisciplinaridade, tratando a epistemologia genética como método interdisciplinar que aspira chegar - quando viável - à transdisciplinaridade, enquanto metassistema total que comportaria dentro de si as conexões sem fronteiras estáveis entre as disciplinas, reunindo Física, Biologia e Psicologia. Para o suíço, entretanto, só é possível a interdisciplinaridade enquanto colaboração de setores heterogêneos entre os quais as interações estabeleçam reciprocidade nas trocas. Recorrendo a analogias interdisciplinares, como no caso da epistemologia genética, que conjuga história das ciências, Psicologia e Biologia para pensar os processos de aprendizagem, ele busca estruturas mais profundas que os fenômenos tais quais se apresentam nos limites do observável dado pela fragmentação das ciências. Já o transdisciplinar corresponderia a uma teoria geral metassistêmica, capaz de englobar as estruturas operatórias e de regulação aos sistemas probabilísticos, conectando a diversidade de possibilidades e respostas através de transformações reguladas e definidas.

Nicolescu (1999) resolve arriscar-se na aventura da transdisciplinaridade, referindo-a como aquilo que está entre, o que atravessa e o que está além das grades disciplinares. Concentrando-se nos dois primeiros sentidos, ele articula o conhecimento transdisciplinar à dinâmica múltipla das diferentes dimensões da realidade e se apoia no conhecimento disciplinar, ao passo que ambos não antagonizam entre si, mas se complementam. 
Entre as disciplinas, se visa alcançar distintos níveis de realidade assumindo a totalidade e a causalidade concebidas em circuitos multirreferenciais capazes de comportar a instabilidade dinâmica. A dinamicidade instável da realidade é causa e objeto das sugestivamente denominadas teorias do caos, que colocam a desordem e a incerteza como desafio que atravessa distintas disciplinas, obrigando-as a incluir a probabilidade e a irreversibilidade em seus procedimentos (SOMMERMAN, 2011).

Tal postura transdisciplinar, crítica à concepção de conhecimento sistematizado linear e unidimensionalmente, requer atenção maior à dimensão conectiva das composições da realidade, exatamente como aparece com a noção de rizoma de Deleuze e Guattari (1994), enquanto rede de conexões implicadas mutuamente. $\mathrm{O}$ conhecer enreda articulando transversalmente o contexto relacional entre o todo e as partes.

\section{2 - Transversalidade e multiplicidade}

No entanto, para buscar um sentido deleuzo-guattariano de transdisciplinaridade, é imprescindível retomar a noção de transversalidade enquanto modo de articulação e potencial reordenamento de distintos níveis, desde e com a qual se atravessam distintos binarismos que organizam a apreensão da realidade. Guattari (1989) propõe a transversalidade como tradução dos graus de abertura necessários à deriva inventiva das práticas sociais que ocorre a medida em que diversos atores tomam posição no processo de produção da realidade, o que indica a superação dos níveis e sistemas de organização restritos às bases e códigos de hierarquização verticais e identificação horizontais. Assumindo que não há um equivalente geral para os processos de subjetivação (uma vez que classe social, diagnóstico psiquiátrico ou gênero não determinam de antemão, necessária e irrevogavelmente um sujeito), transversalizar implica decifrar sistemas de modelização que incidem e arrastam a subjetividade de acordo com referentes e níveis específicos.

A noção de transversalidade faz eco aos acontecimentos disruptivos de Maio de 1968, quando, no embalo do slogan da canção tropicalista, é proibido proibir, o pensamento político e filosófico, atento à derrocada dos modelos de vida e organização social pós-guerra e aos modos de subjetivação em ebulição, não pôde evitar entrar em colapso e deriva.

$\mathrm{Na}$ linha dos que tremeram frente ao caráter disruptivo do acontecimento confundindo-o com a barbárie, Adorno (1997) não titubeou em chamar a polícia quando estudantes ameaçaram invadir o prédio onde dava aulas numa rebelião estudantil no ano seguinte, em 1969. O caráter disruptivo dos movimentos que bradavam a insuficiência das formas de organização da vida e da sociedade também não passou incólume aos algozes militares que interrogaram Caetano Veloso na sua prisão junto a Gil. Os cantores e compositores brasileiros foram presos sob a acusação de fragmentação dos costumes e valores morais.

Estranho emparelhamento que coloca o filósofo da escola de Frankfurt ao lado e na mesma categoria que os militares do regime ditatorial brasileiro. Estrategicamente, o desconcerto em colocar um dos pilares da teoria crítica freudo-marxista ao lado dos interrogadores autoritários, borrões da nossa história marcada pela baixeza de seus atos, traz uma análise transversal dos impasses e atravessamentos entre política e subjetivação.

Essa situação de embaraço possibilita lançar um outro olhar para o tema do fascismo, e mostra a insuficiência de restringi-lo a um corte vertical, que separa em dois lados os grandes nomes da história política. Nesse sentido, vemos a necessidade de interrogar o tema na intimidade e na ligeireza do cotidiano, inclusive no dia-a-dia dos progressismos. Os pequenos fascismos tomam de assalto tanto os funcionários da verdade, que se colocam como proprietários da legitimidade política, como os burocratas da revolução. São figuras que defendem o ascetismo da inspeção dos códigos e condutas e os baluartes das formas consideradas corretas de pensar e discursar politicamente (FOUCUALT, 1996).

Ao provocar rachaduras nessas categorias assépticas, coloca-se em xeque a própria separação entre disciplinas e a dicotomia objetivo-subjetivo que as fundamenta. A partir disso, podemos observar uma moral intelectual do pequeno fascismo que se ocupa com as grandes divisões binárias da realidade (como civilização e barbárie), só elas capazes de enunciar legitimamente a verdade sobre sua época, os homens e a história para com isso manter a política longe do desejo a fim de realizá-la de portas fechadas, por uma vanguarda de escolhidos ou iluminados, que se iluminam e se alternam - eventualmente - entre si.

Destarte, se de um lado há aqueles que operam a manutenção de um certo estado de coisas, por outro, há aqueles que assumiram não apenas os slogans que visam criticar tal situação, mas uma certa atitude de contestação indecodificável. Assumiam a descodificação como novo princípio ético-estético-político. Posição talvez apenas ensaiada por Marcuse (ADORNO, 1997) - que escreve carta repreendendo e rompendo com Adorno -, pelos próprios tropicalistas, e levada adiante por, dentre outros, um filósofo dedicado à produção de diferença na realidade, Gilles Deleuze, e pelo psicanalista e militante de diversos movimentos políticos, Félix Guattari.

Ao analisar a correspondência de Deleuze (2018), vemos a importância e os detalhes deste encontro marcado pela noção de transversalidade. Prontamente, o filósofo identifica a importância desta noção para superar a dicotomia entre inconsciente individual e inconsciente coletivo, de maneira a avançar na construção de um arcabouço capaz de articular marxismo e psicanálise, e também na construção de uma posição crítica capaz de lançar questionamentos sobre uma visão hegemônica que pautava uma certa etiqueta de pensamento e ação da esquerda submetida ao crivo de inteligibilidade da luta de classes e à tutela da ação partidária (FOUCAULT, 1996). Uma pergunta-chave agita este encontro: como o nível socioeconômico interfere no do psiquismo, das formações do desejo, do inconsciente e viceversa? O militante Guattari (2004, p. 126) interroga se a revolução social - a exequível, ou planejável, pelo menos deve ou pode esmagar o desejo? Ambos, junto a Foucault (1996), se perguntam o que liga tão intimamente a exploração social e a repressão psíquica.

Em seu curso sobre a obra foucaultiana, Deleuze (2014) recebe Guattari e ambos planteiam o tema da transversalidade como resposta à emergência de novos tipos de luta e novos tipos de subjetivação insubordinados e irredutíveis à luta de classes e às estratificações por ela ordenadas. Deleuze (2014, p. 151) ainda acrescenta que "uma relação transversal poderia se definir como aquela que por sua natureza une termos, agentes heterogêneos, e cujas funções são heterogêneas". Uma vez que os modos de luta e subjetivação emergentes instituintes, poderíamos dizer - atravessam diagonalmente os diferentes sistemas de homogeneidade, eles extrapolam toda 
análise sistemática, que opera com sistemas homogêneos através de uma tendência de homogeneização global.

No entanto, a questão-chave não é a heterogeneidade atualizada em singularidade absoluta, ou a diferença que, como estado de coisa, está sujeita a recapturas, instrumentalizações ou despotencializações, mas a heterogeneidade processual, a realidade virtual e a potência de cada composição. Estas são irredutíveis ao sistema e inconvenientes, portanto, à análise sistemática. Por isso, Deleuze (2014, p. 152) propõe que a análise "sistêmica, por oposição à sistemática, seria o estudo dos sistemas em desequilíbrio, seria o estudo das relações transversais entre sistemas, isto é, das relações que vão de um heterogêneo, enquanto tal, a outro". A sistemática dialética supõe um conjunto homogêneo e opera axiomas de identidade, nãocontradição e do terceiro excluído, entretanto, ela não alcança o âmbito sistêmico da complexidade, onde os elementos são heterogêneos entre si e as relações entre eles, transversais.

Esta transversal sistêmica analisa e enreda conexões mutuamente implicadas sintetizadas com a noção de rizoma, definida por Deleuze e Guattari (1994, p. 28) desde as "comunicações transversais entre linhas diferenciadas embaralham as árvores genealógicas". Os autores ilustram tais comunicações com duas imagens. Uma delas podemos ver nos vírus, que causam gripes polimórficas, as quais se inscrevem na morte e na evolução da espécie humana. Os vírus são seres transversais, de passagem entre níveis, perpassam e fazem comunicar registros distintos, como as cadeias de DNA do morcego, do pangolim e do humano. A outra imagem seria a da viagem rizomática que, tal qual a literatura estadunidense, prescinde de fundamento, fim ou começo porque parte e se move do meio e entre as coisas para instaurar uma lógica pragmática do $e$, da transpassagem.

A pragmática transversal busca alcançar o plano, noção a partir da qual podemos trabalhar com as instabilidades e heterogeneidades ao invés de buscar a estabilidade e homogeneidade (BARROS; PASSOS, 2000). O plano é onde tudo se comunica (e se compõe ou não), a despeito dos níveis da forma, função ou espécie, nos quais a pragmática transversal opera produzindo cortes e conexões. Uma vez que "traçar uma linha sobre um plano fornece um outro ponto de vista sobre o conjunto de uma situação, um critério imanente que permite analisar os agenciamentos seguindo seus dois pólos, desterritorialização e estratificação (instituições)" (ZOURABICHVILI, 2000, p. 32). Traçar linhas transversais é a operação cartográfica de constituição de um plano problemático como o da microbiologia evolutiva e do campo da saúde no contingenciamento de uma pandemia - como vemos em algumas das pesquisas que apontam para os desafios o futuro a partir do acontecimento da pandemia de coronavírus - ou da subjetivação maquínica de corte e conexão que atravessam diferentes níveis de realidade que articulação entre clínica e política para a Psicologia.

A pergunta sobre os atravessamentos entre subjetividade e política é reposicionada frente aos desafios de lidar com psicose na clínica de La Borde e na formulação de um pensamento sem imagem que se presta à ontologia da diferença e do devir assumidos por Deleuze e Guattari (2011) e elaborados nos termos de uma esquizoanálise. Enquanto articulação transversal clínico-política, ela toma como adversário-chave a compreensão sistemático-estrutural da realidade e do psiquismo.

A concepção que liga o psiquismo à formação políticosocial ecoa em outras searas do saber psi. Especialmente no cruzamento com o tema da saúde mental, Laing (1978) formulou um entendimento da política da experiência, tomando a loucura como um fato socialmente engendrado, produzido e valorado, e partem da ideia de que a liberdade é terapêutica. Em suma, trata-se de buscar a dimensão transcendental do louco sem fetichizar o delírio mas colocando em xeque a própria função de normalização dos saber-poder, sua tendência de remeter toda novidade e irrupção ao campo do desvio e referenciá-la a um interdito ou a uma ordem (seja ela moral ou estrutural, ligada às noções de incapacidade ou de perigo, de inadequação ou ilegitimidade), que está sendo atacada. E a pergunta que não cala a Deleuze e Guattari (2011) é acerca da produção da esquizofrenia. A esquizofrenia enquanto processo que tem modalidades de transcrição e registro próprias, irredutíveis ao intimismo da interioridade psicológica e a seu correlato coextensivo na ordem familiar.

Com a abordagem esquizoanalítica, o psiquismo, o inconsciente e o desejo são liberados das amarras das estruturas, que não descem às ruas - como grafitado em Paris, em 1968 -, nem são capazes de explicar o desejo com seus jogos de substituição dos particulares, de trocas de posições (DELEUZE, 2014), com suas leis e seus interditos.

Tomando a concepção pragmática, transversalista e produtiva da subjetividade, como inconsciente-fábrica ou máquina que agencia a expressão linguística à matéria nãosemiotizada, assim como agencia os territórios existenciais cristalizados ao incorporal do sentido e às aberturas de transvaloração (GUATTARI, 2002), a psicanálise militante e a clínica institucional compreendem a esquizofrenia por aquém e além da triangulação edípica e do familiarismo.

Segundo esta perspectiva, os processos de ontogênese e sociogênese são imanentes. Caso não fossem, os fatores socioeconômicos só atingiriam o inconsciente mediante a alocação do sujeito na estrutura da família. Como se o exterior (político e econômico) só pudesse incidir sobre as formações do inconsciente e do desejo - entendidos enquanto propriedades da subjetividade entendida como interioridade psicológica - sob a mediação pai/mãe num reposicionamento bi-unívoco ao invés de simplesmente binário.

Édipo e a família não incidem ao nível das premissas, dos processos de subjetivação, mas ao do produto e das conclusões que se atualizam sob a forma sujeito. A ideia é que Édipo não é condição estruturante, mas estrutura formalizada, uma vez que o familiarismo não funciona como uma mediação inconsciente geral, ele é generalizado a partir das conclusões, onde incide. Generalizações que servem a uma imagem moral-religiosa do inconsciente, definido como imoral, criminoso ou em relação à lei e a sua transgressão.

Entretanto, compreende-se que o psiquismo não obedece à grade da família, nem podemos aplicar as próprias grades socioeconômicas de maneira determinística a ele, e se o fazemos é apenas de maneira secundária. Com esta nova formulação do problema, entende-se que os mecanismos socioeconômicos incidem sobre o inconsciente e o psiquismo não de maneira sistemática estruturante, mas sistêmica e maquinicamente - na acepção que lhe confere Deleuze (2014). O psiquismo é considerado uma máquina que maquina, que processa e produz a realidade simultaneamente em diferentes níveis, para aquém e além das suas cadeias associativas ou significantes (que são cortadas pelas máquinas) ou das suas linhas costumeiras (Deligny, 2015).

Enquanto operador conceitua, a noção de máquina é proposta por Guattari (2004) em detrimento à de estrutura. 
Com ela, se justifica a reconfiguração do problema da articulação entre clínica e política: não é a estrutura da sociedade que se reveste da estrutura familiar, nem o contrário. Trata-se antes de um funcionalismo do material (que perpassa sistemicamente distintos níveis) que das estruturas das formas (colocadas em um mesmo nível sistemático de homogeneidade). Com isso, nos cabe seguir as linhas materiais detectando nelas as funções a fim de fazê-las funcionar materialmente, produzindo novas formas de subjetividade e de sociabilidade, que não se subordinam necessariamente a algum recorte, binarismo ou estratificação capaz de abarcar a totalidade de sua realidade.

Pois a máquina, é "excêntrica ao fato subjetivo. $\mathrm{O}$ sujeito nela, se acha alhures. [...] O surgimento da máquina marca uma data, um corte, não homogêneo a uma representação estrutural" (GUATTARI, 2004, p. 310) e sua definição reverbera na concepção de um inconsciente maquínico, no lugar de um inconsciente representacional ou estrutural que seria propriedade individual ou coletiva. Neste contexto, vemos como, por um lado, o conceito de fantasma coletivo formulado por Oury (2009) para a psicoterapia institucional como crítica à redução individualista e imaginária do fantasma é uma ressonância importante para a esquizoanálise. Por outro, com a elaboração do qualificativo maquínico, se redefine o psiquismo pelo entre e pelos atravessamentos, como interação instável e multirreferenciada de uma diversidade de intensidades e componentes semióticos que produzem as múltiplas figuras e níveis da realidade e não apenas da realidade subjetiva, que derivaria exclusivamente de conteúdos representativos no esquema estruturalista (GUATTARI, 1989).

Embora produza uma variedade infinita de universos, o inconsciente maquínico dispõe de maneiras muito singulares seus conteúdos e de seus sistemas de intensidades e, assim como não há sintaxe universal capaz de sistematizar tais disposições, as relações inconscientes não dependem de estruturas universais que se desenrolariam em um mesmo nível. Consequentemente, o inconsciente não é o homogêneo em todo o mundo e varia enormemente no decorrer da história. Ele não diz respeito somente ao passado ou à retração no imaginário, mas pode produzir aqui e agora e se abrir para o futuro e com isto, deve-se colocar em questão as noções basilares de neutralidade e universalidade da clínica psicológica fundamentada na cura-padrão, uma vez que elas operam em configurações, dispositivos e situações muito particulares.

Uma vez considerando o inconsciente e o próprio psiquismo como um território suscetível, embora não irredutível, às interações sociais e econômicas que se desenrolam na história, a subjetividade é conceituada a partir do plano de produções histórico-políticas que tem como resto, como efeito, o sujeito. Por isso, Deleuze e Guattari (2011) tratam de subjetividade maquínica, assentada em processos de produção de modos de existência, engendramento de formas de distribuir o sensível nas formas de agir, sentir e dizer o mundo.

Portanto, se a subjetividade é processo e produto, o sujeito é apresentado como máquina de corte e conexão conect-cut - em distintos níveis (familiar, social, histórico, etc.). Pois a realidade é composta de máquinas ligadas umas às outras por fluxos, que emitem fluxos e os cortam. $\mathrm{O}$ exemplo elementar é o seio materno, máquina que produz leite acoplada por uma boca, uma máquina de comer ligada a ela. Logo, todo sujeito é um bricoleur, que produz realidade com as máquinas que se acoplam a ele.

A heterogeneidade maquínica dos processos de subjetivação atrela práticas discursivas e não-discursivas, que agem mutuamente umas sobre as outras. Ao nível desta composição heterogênea, a noção de máquina desejante serve à desconstrução do modelo edipiano da subjetividade e à formulação de uma psiquiatria materialista, que tem como foco a materialidade social, política e afetiva do desejo e da história provocando uma reorientação direcionada às noções de intensidade e de excesso - e posteriormente, assignificante e agramatical (DELEUZE; GUATTARI, 1997) - para a abordagem do tema da subjetividade.

\section{CONCLUSÃO}

Com o que vimos até o momento, seria demasiadamente audacioso requerer ao campo disciplinar da Psicologia que ele abarcasse a complexidade do plano de produção de subjetividades. Atento a isso, François Ewald (1984, p. 90) nos provoca da seguinte maneira:

quer fazer psicologia? Deleuze e Guattari dizem: aprenda a história, percorra as grandes formações da historia universal - "selvagens, bárbaros, civilizados" -, espolie a biblioteca do arqueólogo, do etnólogo, do economista, empanturre-se de literatura e de arte, estão aí as disciplinas do desejo, as disciplinas que relatam no seu conjunto e na diversidade as produções do desejo.

Transversalizar é imprescindível à Psicologia, portanto, à medida em que implica no atravessamento de diferentes níveis e sistemas de entendimento e de realidade.

A partir da dimensão pré-subjetiva, assignificante, intensiva e excessiva que produz a realidade é que temos, por fim, a formulação de uma clínica transdisciplinar como coloca Rauter (2012, 2015). Trata-se, contudo, de uma abordagem irredutível à aplicação de um corpo teórico que a sustentaria. No entanto, isto não quer dizer que a abordagem transdisciplinar seja um novo elixir disposto a resolver as lacunas das demais abordagens. Com a abordagem transdisciplinar, o que está em causa é a problematização da prática clínica, a proposição de estratégias locais e singulares, que se ocupam da construção de novas maneiras de viver e da produção da saúde. Desvencilhada das modelos universalizantes e totalizantes que tendem a tomar a produção de subjetividadade sob um nível sistemático centrado na pessoa, no comportamento ou no inconsciente, etc., com a transdisciplinaridade, a Psicologia pretende extrapolar a intimidade e a individualização do sofrimento.

Logo, assume-se que não há lei sistemática, estrutura nivelante ou falta constituinte capaz de definir a produção psíquica e social. É a produção incessante por cortes e conexões que acaba por organizar o plano subjetivo e social. Por isso, na vida e na política a questão é administrar os encontros, uma empreitada trágica, sem ponto de apoio onde se fundamentar ou garantias de sucesso.

Trata-se de travar pequenas guerrilhas na direção da expansão da vida, de encarar e enxertar na vida distintos níveis de realidade, de forjar outras dobras de subjetividade, capazes de se desvencilhar do ressentimento e seus correlatos da introspecção estéril e da culpa. Seguindo esta linha, Rauter (2012) usa, para introduzir a Clínica do esquecimento, a situação do atraso de um cliente como acesso transversal a dimensões subjetivas outras presentes em seu cotidiano (o trânsito, o corte de cabelo, a biblioteca), deixadas de lado no 
campo da análise do passado, da interiorização e hiperconsciência de si. Com isto, ela faz um apelo à plasticidade do presente a transformar o passado para ultrapassá-lo enquanto apego ao vivido em prol da potência de em novos possíveis agenciáveis no presente.

Destarte, desembaraçada da sistematização disciplinar ao nível do psicológico, a clínica transdisciplinar aborda a produção de subjetivação como um plano aberto a partir da dispersão dos saberes, tomando de empréstimo, recortando e manuseando fragmentos de outros campos do saber numa bricolagem. Com ela, há uma deflação da técnica, enquanto aplicação de conhecimentos a situações previamente concebidas, em prol de uma pragmática transversal, da improvisação com ferramentas capazes de interferir na composição heterogênea e na produção de efeitos de subjetivação.

Entretanto, este devir transdisciplinar não implica ocupar ou lutar pelo lugar de outro saber, não é imitar ou fazer de conta que tem as capacidades e características de outros saberes (DELEUZE; GUATTARI, 1997); não é tomar o lugar, mas provocar, desde seu próprio lugar, mutações dos lugares, no seu, também e sobretudo. Provocação difícil na medida em que requer da Psicologia abrir mão de seus lugares de conforto e reconhecimento, a intimidade e a privacidade, o particular e o privado. Fazer comunicar conjuntos heterogêneos de modo a evitar sobrepor, destacar, extrair ou impor suas próprias noções e operadores. Em outros termos, o devir transdisciplinar da Psicologia não incorre em fazer associações interpostas, uma vez que não se trata, em absoluto, de refazer ou criar novas psicossocologias, psicopedagogias, psicofisiologias, etc. pois

uma linha de devir não se define nem por pontos que ela liga nem por pontos que a compõem: ao contrário, ela passa entre os pontos, ela só cresce pelo meio, e corre numa direção perpendicular aos pontos que distinguimos primeiro, transversal à relação localizável entre pontos contíguos ou distantes. Um ponto é sempre de origem. Mas uma linha de devir não tem nem começo nem fim, nem saída nem chegada, nem origem nem destino. (...) Uma linha de devir só tem um meio. O meio não é uma média, é um acelerado, é a velocidade absoluta do movimento. Um devir está sempre no meio, só se pode pegá-lo no meio. Um devir não é um nem dois, nem relação de dois, mas entre-dois, fronteira ou linha de fuga, de queda, perpendicular aos dois (DELEUZE; GUATTARI, 1997, p. 95-6).

Uma abordagem transdisciplinar da subjetivação é definida não por aquilo que liga, não por seus elementos, mas pelas próprias ligações. Por isso, se define e cresce por elas, que estão no meio, ora acelerando, ora atrasando as conexões entre diferentes níveis da realidade, a qual tende a se apresentar em bloco, especialmente em situações de sofrimento. Assim, traçar transversal e sistemicamente o plano clínico das linhas de multinível de subjetivação já tem o papel de analisador. Com isso, a clínica transdisciplinar ora se dedica mais aos aspectos de resistência e subjetivação, ora observa os aspectos verticais de determinação e/ou horizontais de identificação. A questão fundamental são as ligações, corte e conexão.

$\mathrm{Na}$ suspensão da natureza e da unidade total e própria ao sujeito, a clínica não deixa de ser uma atividade construtivista que presume um desconstrutivismo, uma potencialização da dimensão disruptiva que atravessa e conjuga o sujeito. Pois a desintegração do mundo dos objetos e da temporalidade objetal obstaculiza toda pretensão à totalidade sistemática que fundamenta qualquer objetividade. A atividade de desconstrução é essencial para fazer sobressair o múltiplo substantivo, uma vez que toda subjetivação, sob qualquer instância total ou unitária, não é mais que efeito da multiplicidade que atravessa e constitui a existência.

Tal caráter paradoxalmente construtivista, expresso pelo conectivo $e$, corrobora para tornar obsoleto o interdisciplinar como ligação localizada entre um ponto e outro, em prol de fazer atravessar, passar entre e, quiçá, além, como nos desafiava Nicolescu (1999). O prefixo trans carrega consigo, mais que o sentido de passagem (localizável, como diagonal que articula dois pontos), o sentido de fazer passar e passar entre, de movimento contínuo e de simultaneidade entre os distintos níveis. Logo, é preciso salientar que se

a diagonal libera-se da vertical e da horizontal como coordenadas; da mesma forma, a transversal liberase da diagonal como ligação localizável de um ponto a outro; em suma, uma linha-bloco passa no meio. (...) então, a linha não vai de um ponto a outro, mas entre os pontos ela corre numa outra direção que os torna indiscerníveis. A linha tornou-se a diagonal que se libera da vertical e da horizontal; mas a diagonal já se tornou a transversal, a semi-diagonal ou a direita livre, a linha quebrada ou angular, ou então a curva, sempre no meio delas mesmas. (DELEUZE; GUATTARI, 1997, p. 102)

Atravessando passagens, se fazendo nos meios, a clínica transdisciplinar cria suas próprias coordenadas, novos referentes, outras medidas, meios e operadores para si questão de encontro, na clínica e na política. A proposta fundamental é de que a clínica é tão mais profícua nas interfaces com o que não é eminentemente clínico - no sentido da interioridade psíquica e da intimidade privada. Ela opera na dispersão das inúmeras maneiras de se trabalhar clinicamente a produção de subjetividade, partindo da amplificação dos referenciais e do repertório das práticas, sem a preocupação de formar um campo de saber homogêneo em si mesmo.

Na clínica transdisciplinar, concebida como plano que sintetiza processos existenciais e modos de subjetivar, acompanhamos a deriva destes processos, preferencialmente como verbos no infinitivo, seguindo as indicações das cartografias de Deligny (2015). Ela é a aposta na aproximação da Psicologia com os movimentos de deriva e diferenciação inerentes ao viver, cujas intervenções tomam como horizonte as condições criação de possíveis e o engendramento do novo para os impasses da subjetividade, tomada como experiência no sentido de travessia transformadora.

Consequentemente, o trabalho clínico passa a ser o trabalho de acompanhar, dar passagem ou contenção aos fluxos de diferentes níveis que produzem realidade, que produzem efeitos variados no real. Logo, o plano da clínica psicológica se estende da profundidade do sujeito e sua história pessoal aos efeitos de superfície da multiplicidade cotidiana que compõem fluxos e dobras de subjetividade. Ele não se atém a uma imagem fotográfica do que seria o sujeito, o mundo ou o pensamento para assumir o primado do movimento cinematográfico sobre a estática da fotografia.

Por um lado, a transdisciplinaridade pode ser pautada articulando variados níveis de realidade através do elo da abertura com o teorema de Gödel, que assume a incerteza 
lógica de nosso pensar e a incompletude empírica de nosso saber para abrir diferentes perspectivas de compreensão e explicação da realidade, as quais propiciam soluções e resultados indecidíveis ou contraditórios. Por outro, articular o indecidível e o caos com a criação de modos de vida e a maquinação de subjetividades define os novos funcionalismos e construtivismos de uma abordagem transdisciplinar da clínica (RAUTER, 2012; 2015). Este outro funcional-construtivismo se aproxima da criação num sentido vital e político e na pergunta sobre como funciona cada maquinação entre níveis mais que sobre o que ela é ou significa sob certo nível ou sistema de realidade.

Por fim, a formulação de uma abordagem ética clínicopolítica transdisciplinar para a Psicologia atravessa diferentes níveis, impossíveis de totalizar, de compreender, abarcar ou dar conta em um mesmo sistema ou disciplina. Ela requer, antes, uma rede de conexões mutuamente implicadas, capazes de acessar as dimensões múltiplas e a potência de produção de mundos do cotidiano. Com isto, visa desfazer os fetichismos da diferença em si e da singularidade absoluta em prol dos movimentos aberrantes, de diferenciação e de singularização que nos fazem estranhar a diferença em si.

Para a clínica transdisciplinar, os diversos impasses da vida que mobilizam saúde e subjetivação são respondidos na articulação de saídas múltiplas uma vez que frente à homogeneidade do paredão das repetições e ao incontornável dos acontecimentos, nos cabe administrar encontros a fim de produzir uma estranha diferença em cada um deles.

\section{REFERÊNCIAS}

ADORNO, T. Carta de Adorno a Marcuse. Frankfurt am Main, 5 de maio de 1969. Jornal Folha de São Paulo. Caderno Mais!. 1997.

BARROS, R. B.; PASSOS, E. A construção do plano da clínica e o conceito de transdisciplinaridade. Psicologia: Teoria e Pesquisa, Brasília, v. 16, n.1, 2000.

CAVAlCANTE, L.M.; SILVA, A.K.; GOMES, C. A. R.; HÜNING, S. Foucault e a Psicologia no Brasil: interlocuções e novas perspectivas. Revista Polis e Psique, Porto Alegre, v. 6, n. 2, p. 146-165, 2016.

DELEUZE, G. Curso sobre Foucault - Tomo III: La Subjetivación. Buenos Aires: Cactus Editorial, 2014.

Cartas e outros textos. São Paulo: n-1, 2018.

DELEuZE, G; GUATTARI, F. Mil Platôs: Capitalismo e Esquizofrenia Vol. 1. Rio de Janeiro: Editora 34, 1994.

. Mil Platôs: Capitalismo e Esquizofrenia. Vol. 2. Rio de Janeiro: Editora 34, 1995.

O anti-Édipo: Capitalismo e esquizofrenia I. Rio de Janeiro: Editora 34, 2011.

DELIGNY, F. O aracniano e outros textos. São Paulo: n-1 Edições, 2015

DESCARTES, R. Discurso do método. In: col. Os

Pensadores. São Paulo: Abril Cultural, 1973.

EWALD, F. A Esquizo-análise. In: ESCOBAR, C. O Dossier. Rio de Janeiro: Taurus, 1984.

FIGUEIREDO, L. C. Matrizes do pensamento psicológico. Petrópolis: Vozes, 1991.
FOUCAULT, M. O anti-Édipo: uma introdução à vida não fascista. In: PELBART, P. P. \& ROLNIK, S. (orgs.) Cadernos de subjetividade (número especial sobre Deleuze). São Paulo: Núcleo de Estudos e Pesquisas da Subjetividade da PUC/SP, 1996.

FOUCAUlt, M. As Palavras e as Coisas. São Paulo: Martins Fontes, 2000.

GARCIA-ROZA, L. A. Psicologia: um espaço de dispersão do saber. Rádice, Rio de Janeiro, v. 1, n. 4, p. 20-26, 1977.

GOMES, C. A. R. et al. Diálogos da Psicologia com Michel Foucault. Fractal, Rev. Psicol. Rio de Janeiro, v. 31, n. 1, p. 20-26, Apr. 2019.

GUATTARI, F. Cartografias esquizoanalíticas. Buenos Aires: Manantial, 1989.

\section{Caosmose. São Paulo: Editora 34,2002}

A Transversalidade. In: GUATTARI, F. Psicanálise e transversalidade: ensaios de análise institucional. Aparecida: Ideias e Letras, 2004.

HUR, D. Esquizoanálise e política: proposições para a Psicologia Crítica no Brasil. Teoría y crítica de la psicología 3, 264-280, 2013.

LAING, R-D. A política da experiência e a Ave-doParaíso. Petrópolis: Vozes, 1978.

MORIN, E. Introdução ao pensamento complexo. 3. ed. Porto Alegre: Sulina, 2007.

Brasil, 1996.

Ciência com consciência. Rio de Janeiro: Bertrand

NADAUD, S. Fragmento(s) subjetivo(s). Un viaje hacia las islas encantadas nietzscheanas. Buenos Aires: Cactus, 2017.

NICOLESCU, B. O manifesto da transdisciplinaridade. São Paulo: Triom, 1999.

OURY, J. O Coletivo. São Paulo: Hucitec, 2009.

RAUTER, C. A clínica do esquecimento. Niterói: Editora da UFF: 2012

Clínica Transdisciplinar: Afirmação da multiplicidade em Deleuze/ Spinoza. Revista Trágica: estudos de filosofia da imanência, Rio de Janeiro, vol. 8, n 1, p. 45-56, jan./abr. 2015.

SOMMERMAN, A. Complexidade e transdisciplinaridade. NUPEAT-IESA-UFG, v.1, n.1, jan./jun., 2011.

PIAGET, J. L'Epistémologie des relations interdisciplinaires. In: PIAGET, J. Transdisciplinarité Problèmes d'enseignement et de recherche dans les Universités. Paris: O.C.D.E., 1972

ZOURABICHVILI, F. Vocabulário de Deleuze. Rio de Janeiro: Relume-Dumará, 2000.

\section{COPYRIGHT}

Direitos autorais: Os autores são os únicos responsáveis pelo material incluído no artigo.

Submetido em: 21/09/2020 Aprovado em: 15/10/2020 


\section{Área: Ciências Humanas e Sociais}

\begin{tabular}{|c|l|}
\hline 6-2 & $\begin{array}{l}\text { ELABORAÇÃO DE E-BOOK FACILITADOR PARA A REDAÇÃO DE PATENTES } \\
\text { ELABORATION OF FACILITATOR E-BOOK FOR PATENT WRITING } \\
\text { Leandro Rafael De Abreu; Vanessa Ishikawa Rasoto; Paulo Rogério Pinto Rodrigues; } \\
\text { Cláudia Crisostimo }\end{array}$ \\
\hline 6-2 & $\begin{array}{l}\text { PANORAMA HISTÓRICO-CONCEITUAL DA ISO 9001: UMA ANÁLISE A PARTIR } \\
\text { DE SUAS REVISÕES } \\
\text { ISO 9001 HISTORICAL-CONCEPTUAL OVERVIEW: AN ANALYSIS FROM ITS } \\
\text { REVIEWS } \\
\text { Marina Muniz Do Couto Soares; lale Carine Silva De Oliveira; Sueli Menelau }\end{array}$ \\
\hline 6-3 & $\begin{array}{l}\text { ECONOMIA CRIATIVA E SUSTENTABILIDADE NA GRANDE CUIABÁ/MT } \\
\text { CREATIVE ECONOMY AND SUSTAINABILITY IN GRANDE CUIABÁ/MT } \\
\text { Antônio Ananias Mota Júnior; Raquel Martins Fernandes; Rodrigo Ribeiro De } \\
\text { Oliveira; Maria Geni Pereira Bilio }\end{array}$ \\
\hline
\end{tabular}




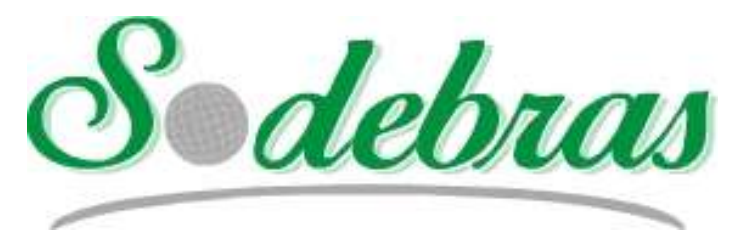

\author{
Revista SODEBRAS - Volume 15 \\ $\mathrm{N}^{\circ} 178$ - OUTUBRO/ 2020
}

\title{
ELABORAÇÃO DE E-BOOK FACILITADOR PARA A REDAÇÃO DE PATENTES
}

\author{
ELABORATION OF FACILITATOR E-BOOK FOR PATENT WRITING
}

\author{
LEANDRO RAFAEL DE ABREU ${ }^{1}$; VANESSA ISHIKAWA RASOTO; \\ PAULO ROGÉRIO PINTO RODRIGUES ${ }^{3}$; CLÁUDIA CRISOSTIMO ${ }^{4}$ \\ 1, 3, 4 - UNIVERSIDADE ESTADUAL DO CENTRO-OESTE (UNICENTRO); 2 - UNIVERSIDADE \\ TÉCNOLÓGICA FEDERAL DO PARANÁ (UTFPR) \\ labreu001@gmail.com; vrasoto@gmail.com; prprodrigues@gmail.com; claudia@unicentro.br
}

\begin{abstract}
Resumo - Este artigo apresenta um e-book para auxiliar pesquisadores a redigirem pedidos de patente. A elaboração do guia levou em conta as orientações relativas a dificuldades encontradas por pesquisadores e foi elaborado a partir da Lei de Propriedade Industrial e nas IN do INPI em vigência. Obteve-se avaliação de alguns usuários que responderam o questionário, como forma de validação. Como resultado, obteve-se o guia prático, para ampla utilização que pode ser utilizado em cursos e para alunos e pesquisadores que queiram redigir patente. Com isso, a proposta deste trabalho foi alcançada, que foi a disponibilização do e-book, de modo permanente em sites de Agências, e poderá ser utilizado amplamente por pesquisadores.
\end{abstract}

Palavras-chave: Propriedade Industrial. Propriedade Intelectual. Guia Prático.

Abstract - This article presents an e-book to assist researchers in
writing patent applications. The preparation of the guide took
into account the guidelines regarding difficulties encountered by
researchers and was prepared based on the Industrial Property
Law and the NI of INPI in force. An evaluation was obtained
from some users who answered the questionnaire as a form of
validation. As a result, the practical guide was obtained, for wide
use that can be used in courses and for students and researchers
who want to write a patent. With that, the purpose of this work
was achieved, which was the availability of the e-book,
permanently on Agency websites, and can be used widely by
researchers.

Keywords: Industrial Property. Intellectual Property. Practical Guide.

\section{INTRODUÇÃO}

A inovação pode melhorar o desempenho de empresas, aumentar a capacidade inovativa, proporcionar melhorias em processos de produção, permitir o desenvolvimento de produtos e novas práticas organizacionais, além de aperfeiçoar a capacidade empresarial de adquirir e criar novos conhecimentos (OCDE, 2005; PUFFAL, RUFFONI \& SCHAEFFER, 2012).

Como explica Dos Santos e Dos Santos (2017), se por um lado, a preocupação com a proteção do conhecimento proveniente de suas pesquisas ou atividades é de extrema importância, uma vez que envolve elementos capazes de resultar em inovação, tecnologias ou bens comercializáveis, totalmente passíveis de cópia ou imitação por empresas, institutos de pesquisa ou até mesmo de universidades de outras partes do mundo. Por outro lado, o desenvolvimento de tecnologias passíveis de patenteamento e de comercialização contribui também para a geração de recursos adicionais principalmente para as Instituições de Ensino Superior (IES), o que pode levar ao aumento de receitas e, com isso, viabilização de investimentos em projetos de interesse dos pesquisadores, muitas vezes não contemplados por repasses governamentais.

Corroborando com esse argumento, Guimarães (2018) completa que o processo para a obtenção da carta patente, no Brasil, é longo e tortuoso, possui uma série de passos e um período mínimo de duração. Isso gera alguns problemas os quais muitos dos pesquisadores ou criadores de inovação não estão inicialmente preparados para enfrentar. E ainda complementa dizendo que a burocracia não é o problema, mas sim a estrutura e a demanda.

A capacitação dos responsáveis por gerir a inovação em empresas e universidades requer cuidados importantes, uma vez que está relacionada à tomada de decisões estratégicas e ao controle das atividades a serem realizadas para a manutenção da propriedade industrial. A instituição deve valorizar a cultura da inovação e investir nas áreas correlatas à gestão da propriedade, verificando a importância desse setor na organização (SILVA, et al., 2018).

As empresas têm alto custo para produção, obtenção, depósitos e manutenção dos ativos intangíveis e, dessa forma, necessitam de maior atenção e valorização da área de propriedade industrial. Portanto, é importante fazer investimentos e dispender esforços, também por parte do governo, que deve se posicionar como um facilitador dos trâmites relacionados à Propriedade Industrial (SILVA; et al., 2018).

A Propriedade Industrial surge num contexto mercadológico gradativamente competitivo entre as organizações, uma vez que aquelas que utilizam a tecnologia em busca de soluções para os problemas ganham cada vez mais força no mundo capitalizado. Para se chegar à inovação, é preciso todo um processo de pesquisa em busca da geração de propriedade intelectual, para, posteriormente, levar o produto ao mercado (SOARES; GOMES, 2017).

Haja vista a necessidade em proteger suas criações e pesquisas por parte dos pesquisadores e universidades por muitos motivos, e que a geração de inovação no Brasil é 
quase que prioritariamente efetivada por pesquisadores das instituições acadêmicas, fica a necessidade dessas instituições se especializarem em registros de marcas, pedidos de patentes e demais formas de proteção para auxiliar e efetivar segurança a esse bem tão importante.

O sistema de propriedade intelectual de um país é criado para garantir a propriedade ou a exclusividade resultante da atividade intelectual nos campos industrial, científico, artístico e literário. Dentro deste sistema, as patentes apresentam-se como um importante mecanismo de troca. Aceita-se oferecer o privilégio da proteção contra a concorrência, no curto prazo, em troca dos frutos da inovação a longo prazo (JÚNIOR; DA SILVEIRA MOREIRA, 2017).

O termo Backlog significa, de forma geral, a acumulação de trabalho em determinado intervalo de tempo, tem sido muito empregado quando o assunto é propriedade intelectual e industrial. Nessa área de conhecimento, backlog refere-se a um obstáculo que atrasa a concessão de patentes no país, podendo ser entendido como a quantidade de pedidos de patentes pendentes por mais tempo do que a duração pretendida, por examinador. Este é um problema encontrado não somente no Brasil, mas também em todo o mundo (GUEDES; SARTORI, 2017).

O INPI tem assistido a um atraso crônico no processamento de pedidos de patentes. Mesmo com dificuldades, o tempo de concessão de patentes no Brasil saltou quatro anos em uma década, atingindo 10,8 anos em 2013. Instituições de propriedade intelectual de vários países já buscaram diversas soluções para o tema. Alguns obtiveram sucesso, conseguindo diminuir, significativamente a quantidade do backlog, e outros, como o Brasil, estão buscando meios com vistas à redução desse problema (GUEDES; SARTORI, 2017).

Com o advento da Lei de Inovação em 2004, a Propriedade Intelectual e Industrial passou a ter mais relevância nas universidades, devido à criação dos NIT, que são órgãos responsáveis pelas questões relativas ao licenciamento, proteção e transferência das inovações tecnológicas (VASCONCELOS; SANTOS, 2019).

Mesmo com obstáculos e algumas diferenças na maneira como cada uma das formas de cooperação é realizada, todas se configuram pela união de duas ou mais organizações, buscando atingir objetivos que, possivelmente, individualmente não conseguiriam (KUHL, 2012).

Considerando os iniciais interessados das inovações criadas, os pesquisadores, a dificuldade enfrentada por eles, pela proteção das patentes e em contrapartida a pouca clareza sobre o funcionamento do sistema de pedidos, abrese uma oportunidade para desenvolver o presente trabalho. Com o objetivo de oferecer aos pesquisadores um material que atenda às suas necessidades em auxiliar no processo de proteção de suas patentes, o presente trabalho propõe a criação de um e-book instrucional denominado "Manual Prático de Redação de Patentes para Pesquisadores".

Esse guia tem linguagem simplificada e direta, com foco na facilitação aos criadores de inovação que queiram solicitar o pedido de suas patentes, ou dar início à escrita dos documentos essenciais, sem a dependência da assessoria de um procurador ou agente de propriedade industrial. Por sua vez, o processo de depósito do pedido de patente é de responsabilidade do Núcleo de Inovação Tecnológica (NIT), quando tratar-se de um pesquisador vinculado a uma
Instituições de Ciência e Tecnologia, ICT pública. Como a utilização dos meios digitais como ferramenta de compartilhamento de conhecimento está cada vez mais comum, buscou-se que o e-book fosse compartilhado em mídias digitais, de forma gratuita para que possa abranger um universo maior de usuários.

O Objetivo geral deste estudo é desenvolver um ebook com informações importantes referentes à redação de patentes direcionado aos pesquisadores criadores de inovação. Os objetivos específicos são:

a) levantar informações referentes aos documentos essenciais para o depósito de Patentes no INPI;

b) selecionar o conteúdo e as formas de apresentação e identidade visual do guia prático;

c) desenvolver o e-book.

\section{METODOLOGIA}

Para o desenvolvimento do e-book "Manual Prático de Redação de Patentes para Pesquisadores" foi utilizado a metodologia de concepção e desenvolvimento de material educativo digital proposto por Falkembach (2005). Esse modelo de construção de material digital envolve a definição do tipo de usuário que vai interagir com a aplicação; a criação da identidade visual (interface) e o conteúdo a ser acessado.

Com o objetivo de conhecer em profundidade os elementos que influenciam os pesquisadores $e$ as necessidades para a redação de patente, utilizou-se a abordagem qualitativa. A pesquisa qualitativa, segundo Gonçalves e Meirelles (2002, p. 46), é mais adequada para a "investigação de valores, atitudes, percepções e motivações do público pesquisado, com a preocupação primordial de entendê-los, em toda a sua profundidade".

Nesta abordagem, empregou-se a natureza de pesquisa descritiva, modalidade mais adequada para descrever as características do fenômeno investigado bem como as necessidades empíricas do processo de redação. Para Gonçalves e Meirelles (2002), os estudos descritivos têm por finalidade caracterizar uma situação, grupo ou indivíduo, identificando a frequência e a forma com que certo fenômeno ocorre ou com que está relacionado a algum outro.

Para a coleta de dados, foram utilizados dados secundários, obtidos dos sites, leis, documentos do NIT e cursos ofertados pelo NIT.

Sendo assim, o e-book foi desenvolvido com as seguintes etapas:

$1^{\circ}$ ) Etapa de Análise e Planejamento - nessa fase foi realizada uma pesquisa interna com o objetivo de identificar o perfil dos usuários que buscam depositar suas patentes e que são atendidos pela Novatec (Agência de Inovação Tecnológica da Unicentro) e suas dificuldades.

Essa etapa foi importante para definir o perfil inicial do público que utilizaria o e-book, de forma que o conteúdo fosse alinhado com as necessidades e interesses desses usuários. Além disso, foi percebido, a partir de cursos ofertados pela Novatec e conversas com palestrantes e responsáveis pelas patentes no NIT, que os pesquisadores têm dificuldade em fazer a redação das patentes, justamente por terem normas diferentes dos artigos científicos.

$2^{\circ}$ ) Etapa de Modelagem - nessa fase definiu-se o conteúdo, o formato de disponibilização, a forma de navegação e ainda a interface com a identidade visual do material. 
$3^{\circ}$ ) Etapa de Implementação - nessa fase foi realizada a lapidação do conteúdo em textos e estruturação do guia. Posteriormente, foi realizada a transferência desses textos para o e-book e efetivada a montagem de todo o material.

$4^{\circ}$ ) Etapa de Avaliação - nessa fase foram realizados testes para verificação de erros e funcionalidade do e-book em diferentes dispositivos (celulares, desktops etc.).

$5^{\circ}$ ) Etapa de Disponibilização - pretende-se realizar a oferta e postagem do e-book com o objetivo de divulgar amplamente e disponibilizar na web o material.

$6^{\circ}$ ) Etapa de Validação: como forma de obtenção de feedback, após a disponibilização do acesso, foram realizadas algumas perguntas a usuários em forma de questionário com cinco perguntas fechadas em escala Likert, de 5 pontos após a leitura do e-book, além de 1 pergunta aberta, com vista a conferir aos pesquisadores a oportunidade de dar sua opinião e contribuir com o aperfeiçoamento constante do material.

As questões para a validação foram as seguintes:

Questão 1 - O que você achou do e-book? Esta questão visa avaliar a qualidade do material disponibilizado;

Questão 2 - O texto é de fácil entendimento? Tem o intuito de verificar o grau de entendimento/dificuldade do usuário em relação ao conteúdo;

Questão 3 - O material conseguiu explicar ou tirar dúvidas referentes à redação da sua patente? Visa verificar se o guia é autoexplicativo;

Questão 4 - Você se imagina conseguindo montar os documentos essenciais do pedido de patente da sua invenção com a utilização desse e-book? Avalia a utilidade do material, bem como a praticidade em utilizá-lo;

Questão 5 - Você indicaria esse e-book para outra pessoa? Questão importante para a disseminação do conteúdo e do conhecimento, bem como o nível de aceitação por parte do usuário;

Já a questão 6 foi uma questão aberta que deixou espaço aos pesquisadores em comentar as suas observações ou sugestões e foi deixada como opcional:

Questão 6 - Observações ou Sugestões (opcional): Importante para oportunizar que o usuário traga sugestões de melhorias ou observações para o aperfeiçoamento do material.

Como coleta de dados para o e-book, utilizou-se informações disponíveis dentro da própria agência por meio do acesso ao banco de dados interno e contato com os gestores da Agência, análise dos cursos de redação de patentes ofertados pelo NIT, bem como dados retirados de sites e leis. Com esses dados foi possível identificar uma série de informações institucionais tais como: a existência de demanda de pesquisadores para patenteamento de invenções; o tipo de atividades que executam e que pretendem patentear; áreas de pesquisa; se já patentearam uma invenção anteriormente, as principais dificuldades enfrentadas com a redação do pedido de patentes.

\section{RESULTADOS}

O e-book elaborado neste estudo, sob o título "Manual Prático de Redação de Patentes para Pesquisadores", é constituído de 29 páginas, elaborado a partir do seguinte sumário: 1 - Relatório Descritivo; 2 - Reivindicações; 3 Resumo; 4 - Desenhos (se aplicável).

Trata-se de uma abordagem direta e objetiva para fins de oportunizar ao usuário identificar exatamente os documentos necessários e na formatação correta, nos termos das Instruções Normativas do INPI, IN/DIRPA n³0/2013 e IN/DIRPA n ${ }^{\circ}$ 31/2013, ambas de 4 de dezembro de 2013 e da Lei de Propriedade Industrial, (LPI), Lei n ${ }^{\circ} 9.279$, de 14 de maio de 1996.

Dentre os tópicos e informações relevantes que foram organizadas no e-book, algumas podem ser apresentadas neste estudo para melhor visão do material. Informa-se também que o e-book completo está disponível no site da Agência de Inovação Novatec.

Como informações iniciais, os pesquisadores devem saber que os documentos devem ser redigidos em arquivos distintos e cada um em formatação e numeração específica. De forma a facilitar a utilização do e-book para o pesquisador, o tópico 1 foi dividido conforme as informações e dados necessários para fundamentar o Relatório Descritivo, o qual deve trazer detalhadamente as características técnicas e dados essenciais da invenção, demonstrado na Figura 1 a forma que o relatório possa demonstrar os critérios de novidade, atividade inventiva e aplicação industrial.

Figura 1 - Relatório Descritivo

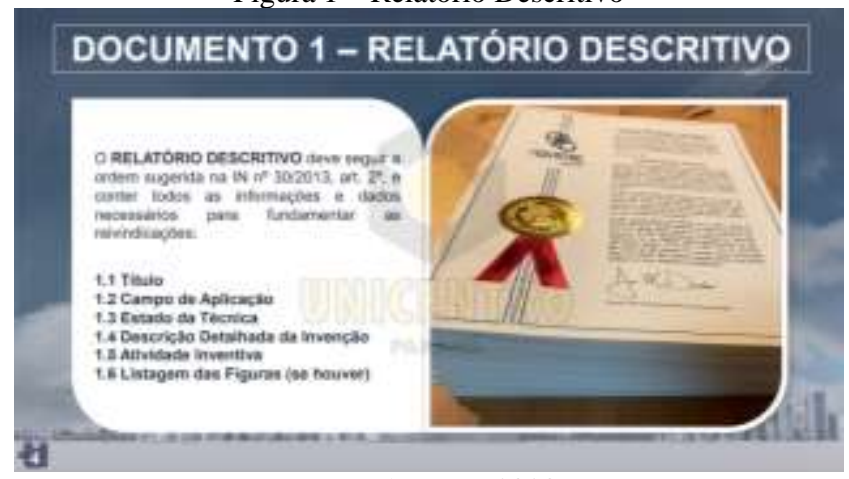

Fonte: Autores, 2020.

De acordo com a IN no 30/2013, art. 2º o Relatório Descritivo deve conter todos as informações e dados necessários para fundamentar as reivindicações, preferencialmente nesta ordem: Título; Campo de Aplicação; Estado da Técnica; Descrição Detalhada da Invenção; Atividade Inventiva; Listagem das Figuras (se houver).

A formatação do Relatório Descritivo está prevista na IN no 31/2013, artigos. 30 a 41. Além da formatação, os itens essenciais do Relatório Descritivo visam fundamentar o escopo da invenção que será definido nas reivindicações. Nesse sentido, o primeiro elemento essencial é o título, que deve ser conciso, claro e preciso, identificando o objeto do pedido, sem expressões ou palavras irrelevantes ou desnecessárias (tais como "novo", "melhor", "original" e semelhantes), ou quaisquer denominações de fantasia e ser o mesmo utilizado no Relatório Descritivo e no Resumo, IN $\mathrm{n}^{\circ}$ 030/13, art. 2, inciso I; IN no 030/13, art. 9, inciso I.

Outra informação que deve ser acrescentada ao Relatório Descritivo é o campo de aplicação. No primeiro parágrafo deve ser incluído o setor técnico a que se refere a invenção, indicando o campo de aplicação ou área tecnológica onde será utilizada a invenção.

Uma outra questão importante a ser verificada são os documentos do Estado da Técnica referentes ao campo da invenção para adequar o pedido de patente frente a estes documentos, demonstrado na Figura 2. De acordo com a Lei de Propriedade Industrial, $\mathrm{n}^{\circ} 9.279 / 96$, é patenteável a invenção que atenda aos requisitos de novidade, atividade 
inventiva e aplicação industrial. Além disso, existem aspectos essenciais que devem ser observados anteriormente à redação da patente.

\section{Figura 2 - Estado da Técnica Buscas}

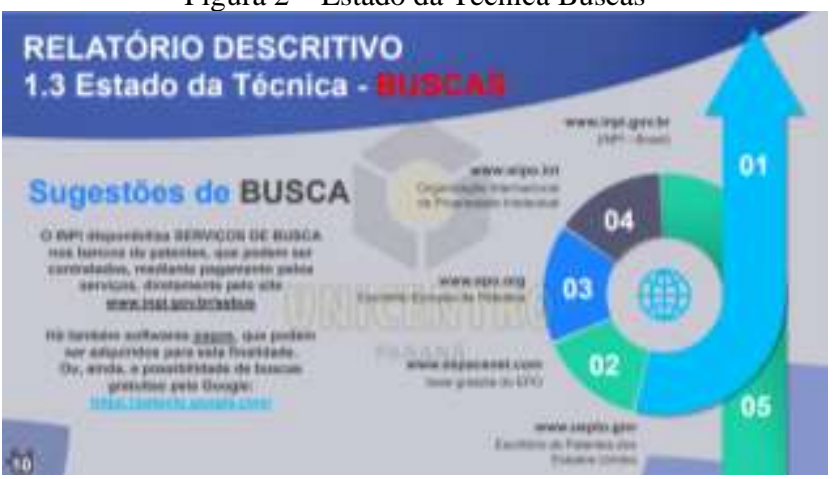

Fonte: Autores, 2020

As fontes de busca de Patentes também são apresentadas no e-book, que compõe a parte de pesquisa que deve ser inserido no processo. É uma das partes mais importantes a ser incluídas, pois demonstra a anterioridade e a autenticidade da patente redigida, e antecipa ao avaliador questões técnicas e diferenças de outras patentes.

A invenção deve ser descrita em detalhes, de maneira suficiente para reprodução da mesma, citando todas as alternativas e variações possíveis relacionadas, tais como materiais, quantidades, temperaturas, etapas, finalidades de uso/aplicação e métodos utilizados no desenvolvimento. Para isso, o item Descrição Detalhada da Técnica,

À parte 1.5 é explicado sobre a atividade inventiva. Uma Invenção apresenta atividade inventiva quando não decorre de maneira evidente ou óbvia do estado da técnica para um técnico no assunto (Art. 13 da LPI). Sendo assim, a invenção dotada de atividade inventiva deve traduzir algo mais do que o resultado de uma mera combinação de características conhecidas ou da aplicação para um técnico, deve contribuir para alcançar resultados diferentes.

Quando houver figuras a serem apresentadas nos desenhos, todas devem estar relacionadas no Relatório Descritivo, especificando as representações gráficas (vistas, cortes, circuitos, diagramas, fluxogramas, gráficos etc.). Á parte 1.6 do e-book, apresenta exemplos a serem seguidos para inclusão de figuras ao relatório.

As Reinvindicações demonstram a parte 2 do e-book e devem ser fundamentadas no relatório descritivo, caracterizando as particularidades do pedido e definindo, de modo claro e preciso, a matéria objeto da proteção (art. 25 , LPI). A extensão da proteção conferida pela patente (escopo da proteção) será determinada pelo teor das reivindicações, interpretado com base no relatório descritivo e nos desenhos (art. 41, LPI).

Cabe ressaltar, que o e-book apresenta um resumo importante para o momento que o pesquisador estiver fazendo a redação e facilita a visualização das formatações a serem empregadas, além de questões importantes a serem analisadas, como evidencia-se na figura 3.

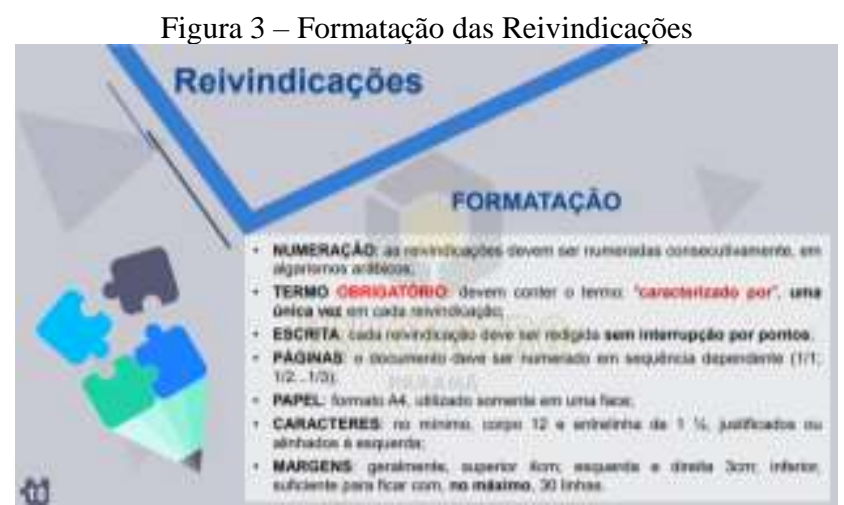

Fonte: Autores, 2020.

A primeira reivindicação, geralmente, deve ser idêntica ao título, bem como as reivindicações independentes devem corresponder às respectivas categorias que definem o escopo da proteção pleiteada.

Devem definir, clara e precisamente, e de forma positiva, as características técnicas a serem protegidas por cada reivindicação.

Uma parte importante sobre as reivindicações são que elas podem ser independentes ou dependentes. As independentes visam a proteção de características técnicas essenciais e específicas da invenção em seu conceito integral, cabendo a cada categoria (produto ou processo) pelo menos uma reivindicação independente.

As dependentes são aquelas reivindicações que, mantida a unidade de invenção, incluem características de outras reivindicações anteriores e definem variações, detalhamentos destas características e/ou características técnicas adicionais.

O resumo representa a parte 3 do e-book, demonstrado pela Figura 4 e é iniciado pelo título, em destaque com relação ao restante do texto, e ainda deve conter uma síntese do que foi exposto no relatório descritivo, nas reivindicações e nos desenhos (quando houver).

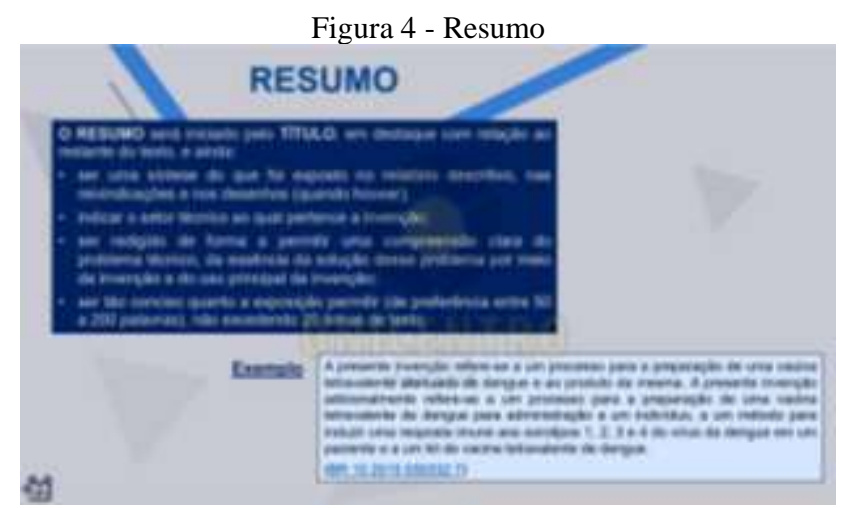

Fonte: Autores, 2020.

Deve também indicar o setor técnico ao qual pertence a invenção. Além da explicação no e-book, é demonstrado um exemplo de resumo a ser utilizado como modelo, de uma Patente já concedida para a Unicentro.

Para a apresentação da parte 4 do e-book, referente aos desenhos, fluxogramas, diagramas e esquemas gráficos deverão conter todos os sinais de referência, tais como algarismos, letras ou alfanuméricos, constantes do relatório descritivo, observando o uso dos mesmos sinais de referência para identificar determinada característica em todos os desenhos, sempre que essa apareça, conforme demonstrado na Figura 5. 


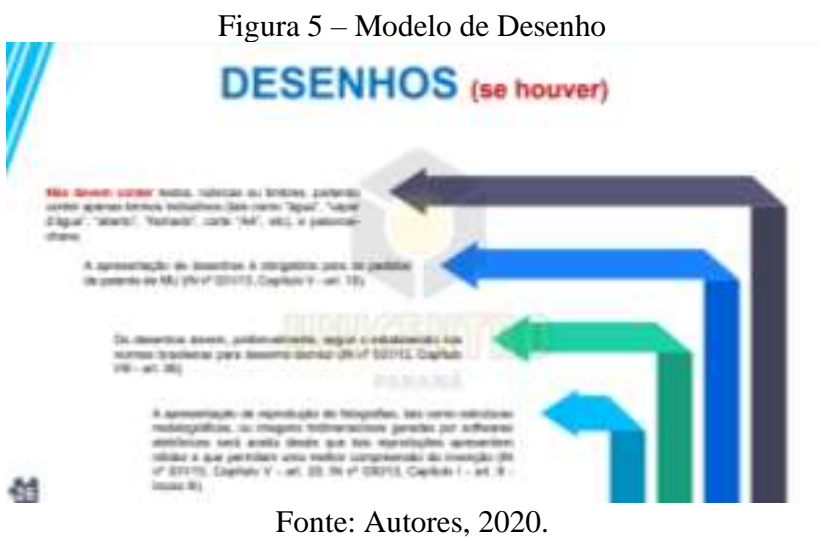

Os desenhos não devem conter textos, rubricas ou timbres, podendo conter apenas termos indicativos (tais como "água", "vapor d'água", “aberto", "fechado", corte "AA" etc.), e palavras-chave.

O e-book, produto deste estudo, contém ao todo 29 páginas e algumas foram incluídas como figuras neste trabalho para demonstrar melhor sua representação. O trabalho ainda detém as devidas informações de referências em seu final, com o referencial utilizado. Por se tratar de um manual prático em formato de e-book, contém também alguns links, que encaminham o leitor a sites e páginas importantes, como Leis e Instruções Normativas, além das patentes utilizados que podem sanar mais algumas possíveis dúvidas dos usuários.

A maioria das páginas do e-book traz exemplos práticos, extraídos de documentos públicos, com a respectiva identificação das patentes pesquisadas para este fim. Além disso, pode-se dizer que o e-book é totalmente complementar ao material encontrado no site do INPI, que é um guia básico referente ao trâmite de depósito de patentes, e o presente estudo trata de um manual prático para a redação dos arquivos básicos para solicitação do depósito.

Para a validação do e-book, dez pesquisadores foram procurados para opinar sobre o material, sendo que oito deles responderam ao questionário. Essa consulta aos usuários visou legitimar o conteúdo e checar a opinião deles sobre a utilização, entendimento do e-book para a redação da sua patente. Para isso, foram elaboradas seis questões, cinco delas de múltipla escolha em escala Likert de 5 pontos, sendo eles: (1) um - muito ruim, 2 (dois) - razoável, 3 (três) - médio, 4 (quatro) - bom e 5 (cinco) - excelente. Foi disponibilizada também uma questão aberta para observações ou sugestões. As questões são as seguintes:

Questão 1 - O que você achou do e-book?

Questão 2 - O texto é de fácil entendimento?

Questão 3 - O material conseguiu explicar ou tirar dúvidas referentes à redação da sua patente?

Questão 4 - Você se imagina conseguindo montar os documentos essenciais do pedido de patente da sua invenção com a utilização desse e-book?

Questão 5 - Você indicaria esse e-book para outra pessoa?

Já a questão 6 foi uma questão aberta que deixou espaço aos pesquisadores em comentar as suas observações ou sugestões e foi deixada como opcional:

Questão 6 - Observações ou Sugestões (opcional): Cabe ressaltar que essa questão foi respondida por quatro dos oito respondentes.
Inicialmente, dos oito respondentes dos questionamentos, obtivemos os seguintes escores, demonstrado na Tabela 1:

\begin{tabular}{lccccc}
\multicolumn{7}{c}{ Tabela 1 } & \multicolumn{5}{c}{ Respostas e Média Aritmética } \\
\hline & Q1 & Q2 & Q3 & Q4 & Q5 \\
\hline R1 & 5 & 5 & 4 & 3 & 5 \\
R2 & 4 & 4 & 4 & 4 & 5 \\
R3 & 5 & 3 & 4 & 5 & 5 \\
R4 & 5 & 4 & 5 & 5 & 5 \\
R5 & 4 & 5 & 5 & 5 & 5 \\
R6 & 5 & 4 & 5 & 4 & 4 \\
R7 & 5 & 5 & 5 & 5 & 5 \\
R8 & 4 & 4 & 5 & 5 & 5 \\
\hline Total & $\mathbf{4 , 6 3}$ & $\mathbf{4 , 2 5}$ & $\mathbf{4 , 6 3}$ & $\mathbf{4 , 5 0}$ & $\mathbf{4 , 8 8}$
\end{tabular}

Considera-se na Tabela 1 os R1, R2, (...) como os pesquisadores respondentes dos questionários, e os Q1, Q2, (...) como as Questões 1 em diante.

Percebe-se que, das oito respostas dos questionamentos, obtivemos os seguintes escores de média total: Questão 1: 4,63; Questão 2: 4,25; Questão 3: 4,63, Questão 4: 4,50; Questão: 4,88.

Pode-se compreender que, apesar de poucos respondentes, todas as médias aritméticas das respostas foram acima de 4, o que demonstra que o e-book teve boa aceitação. A questão 2 obteve a menor nota, levando em consideração que é referente ao texto ser de fácil entendimento, o que pode ser explicado por muitas vezes a redação de Patentes não ser tão fácil. Já a questão 5, referente a indicação do e-book para outros pesquisadores, obteve o score mais alto, o que é um bom sinal de que o material está com uma boa qualidade geral e que os entrevistados indicariam o material para que outras pessoas possam ter essas informações e iniciar suas escritas de patentes.

$\mathrm{Na}$ questão aberta, número 6, obteve-se quatro respostas, que serão analisadas conforme segue:

Um docente que utilizou o e-book fala sobre a redução de tempo no processo:

"Entendo a iniciativa da elaboração de um tutorial para que eu mesmo pudesse fazer a redação de minha patente. Ou até mesmo antecipar algumas questões que podem surgir, e caso precise de ajuda mais específica da Agência, já tenho todas as dúvidas e consigo montar o material da melhor forma possível."

Outro entrevistado está fazendo a redação de sua patente a um tempo, e já teve que procurar a Agência com dúvidas e comentou que:

"Todo o material que possa ajudar é de grande importância, pois no começo até tinha ideia de onde começar, tive que ter uma consultoria com o pessoal da Agência para conseguir o material inicial e entender como funcionam as buscas."

Todavia, um entrevistado apresentou uma opinião diferente dos demais, em relação à utilização à redação das patentes, ele comentou:

"Na minha opinião a Agência deveria ter pessoas para fazer esse serviço de redação de patentes e solicitação de pedidos. Pois é uma coisa muito complicada, e quando nós fazemos, ficamos empacados sempre em detalhes que demoramos a resolver, e um pessoal com mais experiência teria muito mais facilidade em resolver isso." 
Por fim, outro respondente demonstrou interesse em saber mais e elogiou o e-book:

"Um ótimo material. Devemos saber cada vez mais sobre isso, pois é o futuro das instituições de ensino superior. "

Sendo assim, obteve-se uma validação do material elaborado e com as respostas, pode ser observado que o ebook pode ser de grande ajuda para quem quer iniciar a redação de sua patente.

\section{CONCLUSÃO}

Muitas vezes a falta de informação por parte de quem solicita uma patente e a burocracia para preenchimento dos relatórios, são tidos como os principais motivos que distanciam os pesquisadores do processo de pedido de patentes. Dessa forma, se fez necessário e importante desenvolver o produto desse trabalho para reduzir a assimetria em torno do processo de pedido de patentes no Brasil.

Além disso, pelo fato de o Brasil ter um backlog no banco de pedido de patentes, pode-se observar que muito se deve a falhas na escrita dos relatórios, ou em buscas más executadas, o que pode ser evitado por grande parte dos pesquisadores, com as informações corretas. O e-book, que foi construído com uma proposta de ser um guia prático, se mostra como uma nova possibilidade para que o pesquisador brasileiro tenha condições de conduzir, por conta própria, o pedido de sua patente no INPI.

Sendo assim, o objetivo deste trabalho foi alcançado que era desenvolver um e-book com informações importantes referentes à redação de patentes direcionado aos pesquisadores criadores de inovação. Para isso foi elaborado o "Manual Prático de Redação de Patentes para Pesquisadores", com 29 páginas.

Os objetivos específicos também foram cumpridos, sendo o primeiro de levantar informações referentes aos documentos essenciais para o depósito de Patentes no INPI, as Instruções Normativas IN/DIRPA n³0/2013 e IN/DIRPA $n^{\circ} 31 / 2013$, ambas emitidas em 4 de dezembro de 2013 bem como a partir da Lei de Propriedade Industrial, LPI, Lei $\mathrm{n}^{\circ}$ 9.279, de 14 de maio de 1996. As informações foram condensadas e transformadas em conteúdo para o ebook.

O segundo objetivo específico foi selecionar o conteúdo e as formas de apresentação e identidade visual do guia prático, que foi montado a partir de estudos feitos na Novatec, pelos cursos geridos pela agência, e com isso, percebeu-se que muitos pesquisadores procuram as Agências de Inovação para tirar dúvidas simples, o que poderia ser evitado e otimizado o tempo de redação com o auxílio do material elaborado. Cabe ressaltar a importância que os relatórios bem escritos e totalmente dentro das normas podem ter, pois cada ajuste que seja necessário são em média 6 meses de atraso no processo.

Por fim, o último objetivo específico que foi desenvolver o e-book, o qual mostrou-se bastante prático e útil para apresentação em palestras e disseminação para que pesquisadores iniciem os seus processos sozinhos. Pretendese no futuro, e também serve como sugestão para trabalhos futuros, ampliar este guia para a utilização de uma plataforma on-line de cursos à distância, com aulas das partes mais complicadas e exemplificações, que possam incrementar ainda mais este material.

\section{REFERÊNCIAS}

BRASIL. Lei $\mathrm{n}^{\circ}$ 9.279, de 14 de maio de 1996. Lei de Propriedade Industrial. Dispõe sobre direitos e obrigações relativos à propriedade industrial. Diário Oficial da República Federativa do Brasil, 1996. Disponível em: http://www.planalto.gov.br/ccivil_03/Leis/L9279.htm.

Acesso em 21 de dezembro de 2019.

BRASIL. Lei $n^{\circ} 10.973$, de 2 de dezembro de 2004. Lei de Inovação. Dispõe sobre incentivos à inovação e à pesquisa científica e tecnológica no ambiente produtivo e dá outras providências. Diário Oficial da República Federativa do Brasil, 2004. Disponível em: http://www.planalto.gov.br/ccivil_03/_ato2004-

2006/2004/lei/110.973.htm. Acesso em 21 de dezembro de 2019.

DOS SANTOS, L. T.; DOS SANTOS, G. V.; Gestão estratégica da propriedade intelectual em núcleos de inovação tecnológica de universidades públicas brasileiras: desafios e oportunidades. Revista Tecnológica da Fatec Americana, v. 5, n. 2, p. 01-19, 2017.

FALKEMBACH, G. A. M. Concepção e Desenvolvimento de Material Educativo Digital. Novas Tecnologias na Educação - Cinted - UFRGS, v. 3, 2005.

GONÇAlveS, C. A.; MEIRELleS, A. M. Projetos e relatórios de pesquisa em administração. Belo Horizonte: Editora UFMG, 2002.

GUEDES, I. L. B.; SARTORI, R. Backlog: razões, impactos e soluções. Revista EPCC, $1^{\circ}$ Ed. 2017.

GUIMARÃES, B. de B.; Backlog de patentes: a demora do INPI no processo administrativo de concessão como entrave ao desenvolvimento. Dissertação de Mestrado. Salvador, 2018.

JÚNIOR, S. S. G.; DA SILVEIRA MOREIRA, J. de J. O backlog de patentes no Brasil: o direito à razoável duração do procedimento administrativo. Revista Direito GV, v. 13, n. 1, p. 171-203, 2017.

KUHL, M. R. Interdependência entre a colaboração para inovação e o desempenho sustentável na indústria brasileira de eletroeletrônicos. Tese de Doutorado, Universidade Federal do Paraná, Curitiba, 2012.

OCDE, ORGANIZAÇÃO PARA COOPERAÇÃO ECONÔMICA E DESENVOLVIMENTO. Manual de Oslo: diretrizes para coleta e interpretação de dados sobre inovação. 3. ed. [S.1.]: OCDE, 2005.

PUFFAL, D. P; RUFFONI, J.; SCHAEFFER. P. Características da interação universidade-empresa no Brasil: motivações e resultados sob a ótica dos envolvidos. Gestão Contemporânea. Edição especial. Porto Alegre, 2012.

SILVA, E. B. F.; COELHO M. R. S.; SANTOS, M. V. V.; LEITE, R. S. Pesquisa \& Inovação: a Propriedade Intelectual do Estado de Minas Gerais. Cadernos de Prospecção, v. 11, n. 3, p. 757, 2018.

SOARES, I. J.; GOMES, M. F. Propriedade Intelectual, Biodiversidade e Biopirataria: a preservação do patrimônio genético ambiental brasileiro requer regulação eficaz. Revista de Biodireito e Direitos dos Animais, Maranhão, v. 3, n. 2, p. 38-56, jul. /dez. 2017. 
VASCONCELOS, J. R.; SANTOS, J. A. B. dos. Propriedade intelectual na pós-graduação das universidades federais do Nordeste: indicadores bibliométricos. Revista Digital de Biblioteconomia e Ciência da Informação: RDBCI, 2019.

\section{COPYRIGHT}

Direitos autorais: Os autores são os únicos responsáveis pelo material incluído no artigo.

Submetido em: 17/08/2020

Aprovado em: 01/09/2020 


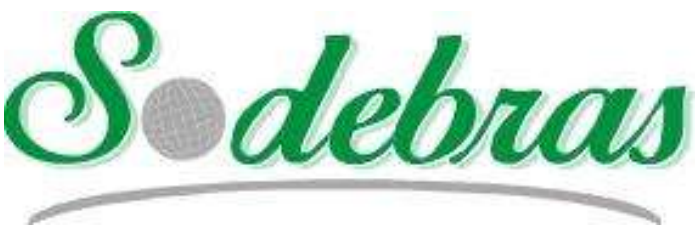

Revista SODEBRAS - Volume 15
N $^{\circ} 178$ - OUTUBRO/ 2020

\title{
PANORAMA HISTÓRICO-CONCEITUAL DA ISO 9001: UMA ANÁLISE A PARTIR DE SUAS REVISÕES
}

\section{ISO 9001 HISTORICAL-CONCEPTUAL OVERVIEW: AN ANALYSIS FROM ITS REVIEWS}

\author{
MARINA MUNIZ DO COUTO SOARES ${ }^{1}$; IALE CARINE SILVA DE OLIVEIRA ${ }^{2}$; SUELI MENELAU ${ }^{3}$ \\ 1; 2 - BACHAREL EM ADMINISTRAÇÃO; 3- DOUTORA EM ADMINISTRAÇÃO \\ marinaacoutoo@gmail.com, iale.carine@gmail.com, suelimenelau@gmail.com
}

\begin{abstract}
Resumo - Este artigo tem como objetivo realizar uma breve reconstrução histórica sobre a norma ISO 9001, para, a partir das revisões realizadas, reconstruir o cenário. Assim, com enfoque qualitativo e delineamento descritivo, emprega como estratégias de pesquisa a bibliográfica e a documental. Conclui-se que as atualizações foram motivadas tanto por mudanças no cenário mundial quanto por necessidades dos usuários.
\end{abstract}

Palavras-chave: ISO. ABNT. Normalização. Certificação. Sistema de Gestão da Qualidade.

\begin{abstract}
This article aims to carry out a brief historical reconstruction on ISO 9001, in order to reconstruct the scenario from the reviews carried out. Thus, with a qualitative focus and descriptive design, it uses bibliographic and documentary research strategies. It is concluded that the updates were motivated both by changes in the world scenario and by the needs of users.
\end{abstract}

Keywords: ISO. ABNT. Normalization. Certification. Quality Management System.

\section{INTRODUÇÃO}

Nos últimos 30 anos, devido ao processo de globalização, as empresas passaram a lidar com uma concorrência mais agressiva e abrangente. Destaca-se que existe uma relação intrínseca entre qualidade e competitividade e na busca por alternativas que propiciem a sustentabilidade dessa competitividade no mercado sem fronteiras geográficas (OLIVEIRA; MELHADO, 2004). As organizações passaram a experimentar inúmeras ferramentas e técnicas gerenciais que conduzam ao aumento da qualidade de seus produtos e serviços (TAMASHIRO; HERMOSILLA; NEVES, 2003).

O maior proveito da gestão da qualidade, e de seus mecanismos, é a possibilidade de criar organizações que alcancem o máximo grau de produtividade e de melhoria contínua (RIBEIRO; ALMEIDA; ANSELMO; SARTORI, 2017). Nesse contexto, emerge nas empresas a necessidade de manterem-se competitivas e de estabelecerem padrões, isto é, fazer a normalização de produtos, serviços e processos. Normalização é a atividade que estabelece parâmetros que evitam problemas, existentes ou potenciais, por meio da utilização comum e repetitiva de normas, com o intuito de obter um grau ótimo de ordem em determinado contexto (OLIVEIRA; MELHADO, 2004).
Com isso em vista, e da necessidade de países interessados em uma normalização internacional, surge em 1946 um fórum internacional de normalização, a International Organization for Standardization (ISO). A premissa é que suas normas reflitam o consenso não só do organismo de normalização de um país, mas que se adeque a realidade de muitos (FERREIRA, 2005). Com este intuito a ISO - que também é o pré fixo empregado em todas as suas normas - tem como finalidade auxiliar na estruturação de países e organizações capazes de balizarem normas voltadas à qualidade de produtos e serviços, a nível global (SOUSA; COSTA-NETO; GOMES, 2019).

A ISO é reconhecida globalmente e é associada a confiança, tendo 21.350 normas voluntárias internacionais publicadas desde sua fundação, desenvolvidas por comitês técnicos (TC, do inglês Techinical Committee) (ISO, 2016). Os documentos normativos gerados consistem em normas técnicas internacionais. O TC 176 é o que lida com gestão da qualidade e garantia da qualidade, e é o responsável pelo desenvolvimento e pela atualização das normas da série ISO 9000 (FERREIRA, 2005). Segundo Pinto, Carvalho e Ho (2006), as normas ISO 9000 rapidamente tornaram-se uma referência para o Sistema de Gestão da Qualidade (SGQ) de organizações.

O SGQ deve demonstrar conhecimento da aplicação de legislação e da regulamentação dos requisitos, podendo ser usado para obter certificação e propósitos contratuais da organização (ISO, 2016). Um SGQ deve também garantir a qualidade interna e externa à organização e se embasar em três pontos: consistência de produtos e processos, identificação dos requisitos do cliente e melhoria contínua do sistema produtivo (FERREIRA, 2005; VERGARA; YAMANARI; BARBOSA, 2019). A norma ISO 9001 é entendida como um modelo para construir um SGQ, voltada à certificação, aos fins contratuais e à garantia da qualidade interna (FERREIRA, 2005).

A norma ISO 9001 é vista como a mais abrangente da série ISO 9000, pois compreende as atividades de projeto, desenvolvimento, produção, instalação e serviços associados, especificando os requisitos básicos que a empresa deve cumprir para o gerenciamento do SGQ (HECKERT; FRANCISCHINI; ROTONDARO, 1998). É possível visualizar o peso que esta norma tem para a ISO ao se observar a quantidade de certificados que reúne mundialmente. A ISO 9001 em 2011 detinha 6.780 
cerificados válidos (CARPINETTI; MIGUEL; GEROLAMO, 2011). No mundo, atualmente a ISO 9001:2015 soma 883.521 certificados válidos (ISO, 2020), o que faz dela a norma da ISO com o maior número de certificações. Do total de certificados mundiais, 17.952 foram obtidos no Brasil, posicionando o país em $10^{\circ}$ lugar no ranking mundial (ISO, 2020).

Para Fonseca e Domingues (2017), a certificação ISO 9001 é buscada porque traz visibilidade à adoção e à intensidade dos SGQs nas organizações e por possuir papel importante para os negócios internacionais. Portanto, a importância da ISO 9001:2015 reside em não só auxiliar na padronização de processos como também contribuir para o rompimento de barreiras comerciais, podendo vir a facilitar negociações internacionais (OST; SILVEIRA, 2018). Advoga-se que a implementação da norma auxilia as empresas a estarem em conformidade com exigências internacionais voltadas para exportações e, consequentemente, contribui para a melhoria de seu SGQ e o aumento dessas organizações (HAMMES et al., 2018).

Os requisitos da ISO 9001:2015 são descritos como genéricos e têm a pretensão de serem aplicados em qualquer organização, independentemente do seu tipo ou tamanho, ou mesmo da categoria de produtos e serviços que oferte (ISO, 2015). No Brasil, por exemplo, os cinco setores que acumulam os maiores volumes de certificados válidos desta norma até 31 de dezembro de 2019, em ordem decrescente, são: produtos de metal básico e de metal fabricado; serviços de engenharia; produtos de borracha e plástico; outros serviços; e o de equipamento elétrico e óptico (ISO, 2020).

Destaca-se que as normas da ISO são analisadas regularmente para manterem-se relevantes e as mudanças são efetuadas quando se é demonstrada uma necessidade de melhorar determinada norma (ISO, 2016). Assim, a ISO 9001 passou por quatro revisões desde seu surgimento, em 1987, até chegar na versão atual, de 2015. Suas atualizações são indicativos de tendências mundiais, de modo que uma análise da evolução das versões tende a ser um estudo sobre os fatores que impactaram os negócios internacionalmente ao longo dos anos. Sob este contexto delineado, o presente estudo objetiva realizar uma breve reconstrução histórica sobre norma ISO 9001, para, a partir das revisões realizadas, reconstruir o cenário.

A relevância do estudo situa-se, dentre outras, em uma contribuição sistematizada sobre os indutores que levaram a evolução da norma, uma vez que a norma ISO 9001 tem um papel de destaque a nível mundial e é uma ferramenta popular para adoção de um SGQ nas empresas (FONSECA; DOMINGUES, 2017). Para tanto este texto estrutura-se, além desta parte introdutória, em mais três outras seções: método, desenvolvimento e conclusão. A seção de método esclarece os procedimentos metodológicos para execução da pesquisa. O desenvolvimento aborda a evolução da ISO 9001 de 1987 até a versão de 2015. Por sua vez, a conclusão apresenta uma reflexão quanto aos indutores pelos quais a norma passou pelas alterações.

\section{MÉTODO}

Para se alcançar o objetivo proposto para o estudo, adotou-se o enfoque da abordagem qualitativa, já que se buscou a investigação do fenômeno (ROESCH, 1999). Foram duas as estratégias de pesquisa adotadas: bibliográfica, empregada como primeiro passo e também para subsidiar a análise; e documental, com coleta dos dados primários na norma ISO e em suas atualizações.

Desse modo, o delineamento da pesquisa é descritivo, uma vez que que os elementos constitutivos do fenômeno estão apresentados localizados no tempo e no espaço (ROESCH, 1999). A análise dos dados apoiou-se em Creswell (2007), tendo seguido o seguinte plano sequencial: leitura inicial de informações, desenvolvimento da descrição e representação dos resultados.

Como a análise não envolveu a coleta de dados com pessoas e a apenas material disponibilizado na internet, não foi necessária a submissão do estudo ao Comitê Ético de Pesquisa (CEP).

\section{RESULTADOS}

Segundo Ferreira (2005), a evolução histórica dos sistemas normalizados de gestão revela que tiveram seu início relacionado ao fornecimento para governos e organizações militares. A primeira norma voltada ao SGQ emergiu em torno de 60 anos atrás (a MIL-Q-9858A), e a precedente a da ISO 9000 (a BS 5750) há quase 40 anos de antecedência. A cronologia das primeiras normas de gestão voltadas à qualidade está ilustrada na Figura 1:

Figura 1 - Primeiras Normas Voltadas ao SGQ

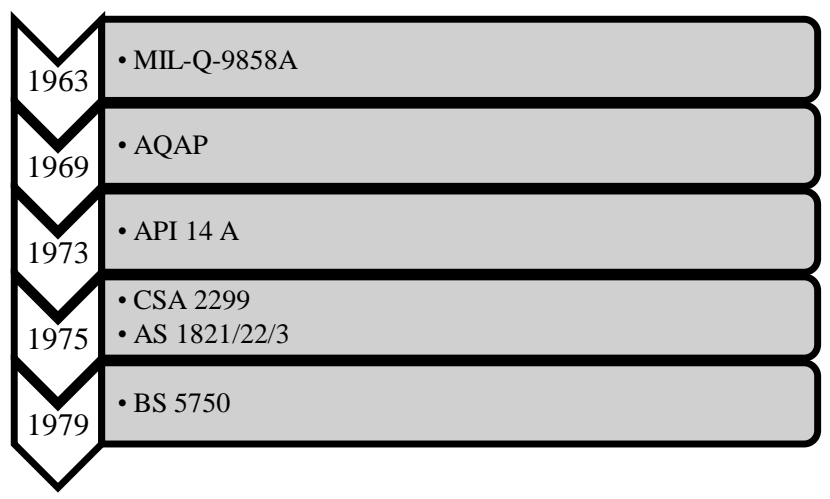

Fonte: Elaborado a partir de Ferreira (2005).

Ainda sobre a Figura 1, a API 14 A não foi uma norma proposta por uma entidade governamental (é da American Petroleum Institute) e a AQAP foi proposta pela Organização do Tratado do Atlântico Norte. Por sua vez, a BS 5750 Quality Systems, publicada pela British Standards Institution (BSI) em 1979, utilizada para avaliar o SGQ de fornecedores, serviu de fundamento para a produção da série ISO 9000 (BSI, 2017; FERREIRA, 2005). As normas da série ISO 9000 emergiram devido a dois importantes indutores (Figura 2):

Figura 2 - Indutores da Série ISO 9000

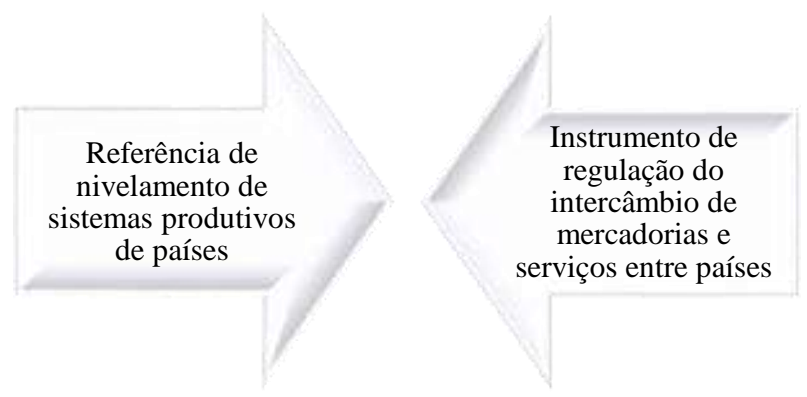

Fonte: Elaborado a partir de Oliveira e Melhado (2004). 
Arnold (1994) explica que a versão da série ISO 9000 1987 era composta por cinco normas - ISO 9000, ISO 9001, ISO 9002, ISO 9003 e ISO 9004 - e cada uma atendia a requisitos específicos. O objetivo era estabelecer um instrumento de referência em relação a qualidade dos produtos (OLIVEIRA; MELHADO, 2004). Atualmente, a série ISO 9000 tem quatro normas principais, a saber (Quadro 1):

\begin{tabular}{l|l}
\multicolumn{2}{c}{ Quadro 1 - Principais Normas Série ISO 9000 } \\
\hline NORMA & OBJETIVO \\
\hline ISO 9000 & $\begin{array}{l}\text { Fornecer conceitos, princípios e vocabulários } \\
\text { fundamentais utilizados em toda a série }\end{array}$ \\
\hline ISO 9001 & $\begin{array}{l}\text { Especificar os requisitos básicos que, ao } \\
\text { serem cumpridos, possibilitam que a } \\
\text { organização seja certificada por um } \\
\text { organismo externo }\end{array}$ \\
\hline ISO 9004 & $\begin{array}{l}\text { Ampliar os benefícios obtidos por uma } \\
\text { empresa com a ISO 9001, buscando melhoria } \\
\text { sistemática e contínua do desempenho geral } \\
\text { da organização }\end{array}$ \\
\hline ISO 19011 & $\begin{array}{l}\text { Orientar programas de auditoria que } \\
\text { auxiliem a garantir que o SGQ implementado } \\
\text { atenda aos requisitos da ISO 9001 }\end{array}$ \\
\hline
\end{tabular}

Voltando-se a ISO 9001, inicialmente era nomeada 'Modelos de Garantia de Qualidade Projetos/ Desenvolvimento, Produção, Instalação e Assistência Técnica', e foi considerada a mais abrangente, pois atendia a uma maior quantidade de requisitos que as demais da família de 1987 (ARNOLD, 1994). A versão de 1987 se incumbiu de servir como um normativo de referência mundial, uma vez que existiam normas variadas em diversos países dificultando a utilização de SGQ pelas empresas, pois algumas regras contrariavam outras (ARNOLD, 1994; OLIVEIRA; MELHADO, 2004).

De acordo com Lambert (2017), a versão ISO 9001 de 1987 foi popularizada após a Primeira-Ministra da Inglaterra Thatcher criar um programa nacional de qualidade para equiparar o design e a qualidade da indústria britânica com a japonesa, incentivando as empresas do país a adotarem a ISO 9001. Assim, a disseminação da ISO 9001:1987 foi decisiva para desmistificar a premissa do mercado que o sistema de normas convinha apenas para a manufatura e não para organizações como um todo.

Ressalta-se que para que as organizações possam obter a certificação da ISO 9001 é necessário que um organismo de certificação independente realize a auditoria do SGQ que essas empresas possuem para verificar se atendem aos requisitos da norma e alcançam os resultados pretendidos (FONSECA; DOMINGUES, 2017). O credenciamento dessas entidades é voluntário e não obrigatório, e as organizações certificadas devem realizar auditorias de manutenção semestral ou anual CARPINETTI; MIGUEL; GEROLAMO, 2011).

Sobre suas revisões, a ISO 9001 passou por quatro substanciais desde 1987: a primeira em 1994, a subsequente em 2000, a terceira em 2008 e, mais recentemente, a quarta atualização em 2015 (LAMBERT, 2017). Em sua primeira revisão em 1994, o enfoque principal se deu no parâmetro conformidade. Nesse sentido, Oliveira e Melhado (2004) declaram que os requisitos da versão ISO 9001:1994 atuavam para evitar a não-conformidade desde a confecção do projeto até a assistência técnica do produto e serviço em questão.
Val (2004) classifica a ISO 9001:1994 como burocrática, uma vez que contava com guias padronizados que davam instruções sobre como os processos deveriam ser realizados para atender cada requisito da norma. Após analisar críticas dos usuários em relação à versão de 1994 e sugestões de solicitação por uma norma que enfocasse os processos da organização, a relação com os clientes e a melhoria contínua do desempenho do SGQ, a ISO 9001 de 2000 foi publicada com o objetivo de minimizar a tendência à manufatura (OLIVEIRA; MELHADO, 2004; SAMOHYL, 2005).

A segunda revisão, de 2000, refletiu um viés na quantificação do conhecimento e buscou alinhar-se com a tendência mundial de gestão da qualidade ao basear-se em oito princípios consensuais dos modelos de maturidade empresariais que se desenvolveram com o advento dos prêmios de qualidade (FERREIRA, 2005; SAMOHYL, 2005). Tais indutores de mudança da segunda atualização da norma são (Figura 3):

Figura 3 - Indutores de Mudança da ISO 9001:2000

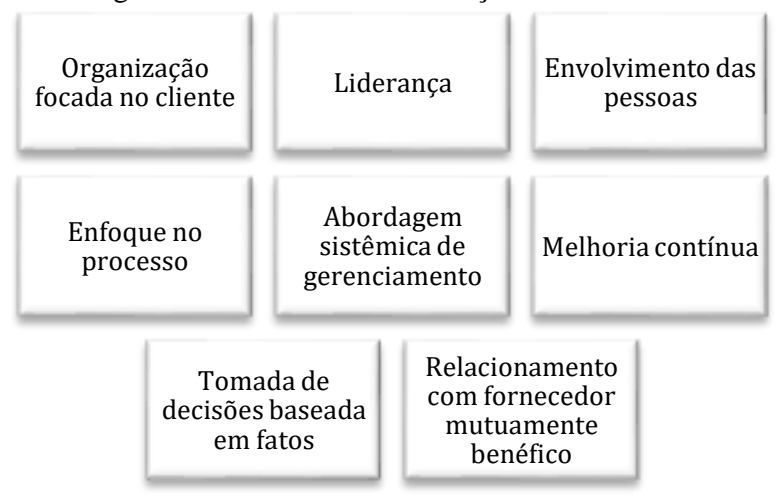

Fonte: Elaborado a partir de Ferreira (2005).

A partir de 2000, a norma ISO 9001 é estruturada da seguinte forma: (i) introdução; (ii) escopo; (iii) referências normativas; (iv) termos e definições; (v) SGQ; (vi) responsabilidade da administração; (vii) gestão de recursos; (viii) realização do produto; e (ix) medição, análise e melhoria. Oliveira e Melhado (2004) explicam que nessa nova estruturação, as quatro primeiras seções fazem uma apresentação prévia da estrutura da norma, enquanto as cinco seções que as sucedem são compreendidas como seções básicas. E Carpinetti, Miguel e Gerolamo (2011) assinalam que essa mudança estabeleceu requisitos de qualidade para todas as etapas do ciclo produtivo.

As seções básicas, de acordo com Samohyl (2005), favorecem procedimentos de análise com tendência estatística. Com base neste escopo, Pinto, Carvalho e Ho (2006), ajuízam que a ISO 9001 de 2000 foi um avanço com relação a versão de 1994. Esta relação de superioridade entre as duas versões pode ser visualizada no Quadro 2:

Quadro 2 - Diferenças entre a Segunda e a Terceira ISO 9001

\begin{tabular}{l|l}
\hline VERSÃO 1994 & VERSÃO 2000 \\
\hline $\begin{array}{l}\text { Não se exige que a alta } \\
\text { direção comprove estar } \\
\text { gerenciando o SGQ }\end{array}$ & $\begin{array}{l}\text { Deve haver evidência de que a } \\
\text { alta direção esteja comprometida } \\
\text { com o SGQ e tomando suas } \\
\text { decisões embasadas nele }\end{array}$ \\
\hline $\begin{array}{l}\text { Satisfação dos clientes } \\
\text { como objetivo da norma, } \\
\text { porém não se exige sua } \\
\text { medição com o intuito de } \\
\text { demonstrar melhorias }\end{array}$ & $\begin{array}{l}\text { Satisfação dos clientes como } \\
\text { exigência de medição da norma } \\
\text { que pode ser feita por meio de } \\
\text { técnicas de pesquisa que } \\
\text { possibilitem a retroalimentação }\end{array}$ \\
\hline
\end{tabular}


Requisitos que se referem à política de qualidade apresentados apenas na subseção '5.4.1 Objetivos da Qualidade'

A melhoria contínua não é exigida explicitamente, mas há um conjunto de itens que acabam gerando uma melhoria dos processos do sistema, embora não tragam os resultados esperados Ocasionou interpretações equivocadas quanto ao volume necessário de registros documentais, que reprimiam a flexibilidade devido ao excesso de documentos e registros gerados

Requisitos voltados à criação e ao

desenvolvimento de produtos não são amplos

Há o viés de ambiguidade na interpretação quanto à aplicabilidade dos requisitos de manuseio, armazenamento, embalagem e preservação O sistema de qualidade é responsável apenas pela garantia do cumprimento dos requisitos da qualidade (enfoque na garantia da qualidade)
Requisitos referentes à política da qualidade permeiam o texto das cinco seções básicas, indicando que os objetivos da qualidade devem ser traçados e divulgados pela organização

A melhoria contínua da eficácia do SGQ se torna requisito explícito dentro da norma e é atribuída mais responsabilidade à alta direção para seu alcance

Apenas seis elementos do SGQ são especificados como necessários a terem seus procedimentos documentados, diminuindo a produção de documentos, e incentivando análise, simplificação e melhoria de processos

Incorporação de requisitos que contemplam o processo de desenvolvimento do produto, indo além da atividade pura do projeto

Evidencia que itens de manuseio, armazenamento, embalagem e preservação se aplicam não apenas ao produto final, mas a todos os estágios de processamento interno O sistema de qualidade é responsável por gerenciar atividades e recursos da organização (enfoque na gestão da qualidade)
Fonte: Elaborado a partir de Oliveira e Melhado (2004).

Complementando as informações do Quadro 2, para Hammes et al. (2018) e Samohyl (2005), os esforços que as organizações precisaram fazer para se adequarem às mudanças nas exigências da ISO 9001 lhes proporcionou maior controle de suas atividades. Com isso, a terceira atualização auxiliou as empresas no processo de melhoria contínua e lhes possibilitou conseguir operar de forma mais eficiente e eficaz, aprimorando seus indicadores econômicos (HAMMES et al., 2018).

Tratando-se da terceira atualização, a de 2008, as modificações realizadas na ISO 9001 visavam apenas alterar o detalhamento ou a escrita de algumas condições, mantendo os requisitos de gestão da qualidade presentes da versão ISO 9001:2000 (MIRANDA, 2014). Esses requisitos são aqueles chamados por Oliveira e Melhado (2004) de seções básicas da estrutura da ISO 9001:2000, e são os métodos de gestão da qualidade inter-relacionados, pois formam um processo cíclico de melhoria contínua do SGQ (CARPINETTI, 2012).

Para Chaves e Campello (2014), a falta de novidades significativas em relação à versão de 2000 acabou por decepcionar profissionais que estavam ávidos por muitas alterações na norma ISO 9001:2008. Avaliou-se que além da estrutura da versão de 2008 da norma permanecer igual à estrutura da ISO 9001:2000, os oito princípios de gestão da qualidade também se mantiveram presentes (CHAVES; CAMPELLO, 2014).

A falta de novidades impactantes na revisão de 2008 foi proposital, visto que a norma foi tratada como uma emenda e foi definido, segundo a ISO (2008), que as alterações feitas não poderiam gerar altos impactos. Dessa forma, os quatro principais benefícios percebidos nas modificações da ISO 9001:2008 foram: promoveu maior clareza da versão de 2000; tornou a norma mais compatível com a ISO 14001:2004; manteve a consistência com as demais normas da série ISO 9000; e facilitou o processo de tradução (ISO, 2008).

Apesar de a versão ISO 9001:2008 não ter agradado por unanimidade e não possuir grandes modificações, no cenário brasileiro, continuou a produzir efeito positivo na economia do país (HAMMES et al., 2018). Avaliou-se que na medida em que as organizações aderiram a certificação ISO 9001:2008 e apresentaram melhora de seus indicadores econômicos, o Produto Interno Bruto (PIB) do Brasil cresceu e a taxa Selic caiu, e que entre 1996 à 2016 o efeito da implementação da norma pelas organizações brasileiras foi positivo para o crescimento do PIB do país e do volume de exportações (HAMMES et al., 2018).

A revisão mais atual da norma ISO 9001 ocorreu em 2015, e sobre a estruturação de suas seções, as de apresentação prévia se mantiveram - de (i) a (iv) -, mas a seção básica passou a ser composta por: ( $v$ ) Contexto da organização; (vi) liderança; (vii) planejamento; (viii) suporte; (ix) operação; $(x)$ avaliação de desempenho; e (xi) melhoria. A Associação Brasileira de Normas Técnicas (ABNT) classifica duas mudanças como as mais significativas na ISO 9001:2015: a estrutura geral, que passa a ser a mesma que as demais normas dos SGQs; e a atenção extra à análise de risco, que possibilita que os usuários lidem com os riscos de acordo com os requisitos do sistema, de forma estruturada (ABNT, 2015).

Sousa, Costa-Neto e Gomes (2019) também compreendem o foco em risco da versão de 2015 como uma grande mudança desta atualização, por bordá-los como elementos inerentes aos processos, de modo a se evitar e prevenir possíveis perdas que venham a acometê-los. Contudo, a análise de risco é destacada por Fonseca et al. (2019) como o maior obstáculo das organizações certificadas anteriormente no processo de atualização versão 2015.

As dificuldades residem em que as organizações devem não só identificar e gerenciar riscos e oportunidades que podem vir a afetar seu SGQ e os resultados almejados, como também devem ter ações voltadas para lidar com esses elementos (FONSECA; DOMINGUES, 2017). Ainda assim, Ost e Silveira (2018) avaliam que essa nova abordagem quanto a riscos implementada pela ISO 9001:2015 proporciona mais credibilidade para a norma dentro das organizações.

A ABNT (2015) advoga que a ISO 9001:2015 é implementada com mais facilidade por organizações de serviço e tecnologia, tem uma abordagem do supply chain mais eficaz, propõe um envolvimento de lideranças maior e tem uma linguagem mais acessível com estrutura e termos informais que facilitam seu uso. Esse entendimento da versão atual da norma como mais acessível e flexível é corroborada por Pastor-Fernández e Otero-Mateo (2016), que entendem a ISO 9001:2015 como uma atualização descomplicada de suas versões anteriores.

Assoma-se a esse entendimento o fato de que nas versões anteriores as organizações tiveram como prazo três anos para realizarem a re-certificação para renovação do certificado. Entretanto na ISO 9001:2015, apesar de ter seguido o padrão anterior do certificado válido por três anos, permitiu a prorrogação do prazo à adequação do SGQ das organizações continuarem a atender os requisitos da norma. 
Segundo a United Kingdom Accreditation Service (2018), o prazo se estendeu até 15 de março de 2019 e só foi válido para as empresas que comprovaram ter iniciado o processo de auditoria para a re-certificação antes de 15 set 2018 .

$\mathrm{O}$ setor que engloba químicos, produtos químicos e fibras é o décimo dentre os que apresentam maior quantidade de certificações da ISO 9001:2015 no Brasil (ISO, 2020). Mas, empresas químicas brasileiras que passaram pelo processo de transição entre a versão de 2008 e a de 2015 concordam com as alterações realizadas e acreditam em seus benefícios, porém, parte considerável admitiu ter passado por dificuldades na aplicação dos requisitos (OST; SILVEIRA, 2018).

De acordo com Lazarte (2015), a versão de 2015 é menos prescritiva que as versões anteriores, foca mais em performance e passou a aplicar o Ciclo PDCA (do acrônimo em inglês Plan, Do, Check e Act) em todos os níveis da organização. Nesse sentido, segundo Fonseca e Domingues (2017), a ISO 9001:2015 está em conformidade com conceitos modernos de negócios e de gestão da qualidade. A seguir, a Figura 4 traça uma linha do tempo sobre os indutores decisivos às atualizações da ISO 9001 até a versão atual:

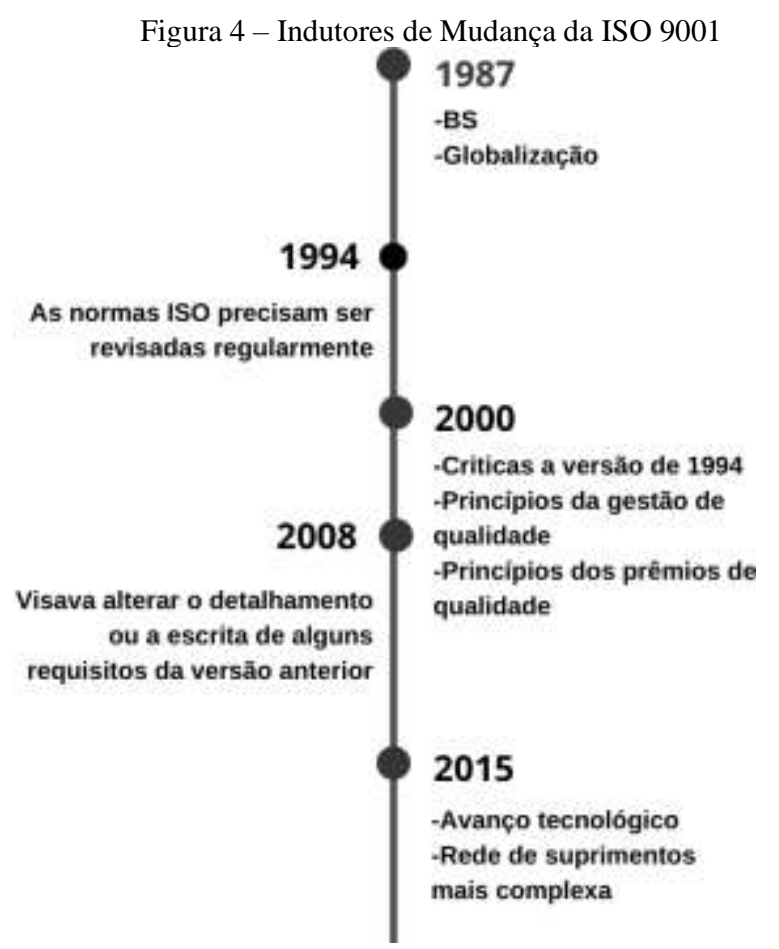

Fonte: Elaborado com base em ISO (2016), Lazarte (2015), Miranda (2014), Oliveira e Melhado (2004) e Starke et al. (2012).

Complementando a Figura 4, as principais diferenças entre as versões provocadas por esses indutores de mudança, são (Quadro 3):

Quadro 3 - Diferenças entre as Versões da ISO 9001.

\begin{tabular}{|c|c|}
\hline VERSÃO & MODIFICAÇÃO \\
\hline 1987 & $\begin{array}{l}\text { Transformação da BS5750 em norma } \\
\text { internacional; teve como principal objetivo } \\
\text { prevenir a não conformidade de produtos, uma } \\
\text { vez que em um contexto de mercado } \\
\text { globalizado havia uma necessidade maior de } \\
\text { padronização }\end{array}$ \\
\hline 1994 & $\begin{array}{l}\text { Ênfase na garantia de qualidade para além da } \\
\text { prevenção de não conformidade de produtos, } \\
\text { incluindo conformidade de serviços e } \\
\text { processos }\end{array}$ \\
\hline
\end{tabular}

\begin{tabular}{l|l}
\hline 2000 & $\begin{array}{l}\text { Além do enfoque continuar na garantia de } \\
\text { qualidade, mudanças na: exigência por } \\
\text { melhoria contínua, redução do volume de } \\
\text { documentação exigida e na mensuração da } \\
\text { satisfação de clientes }\end{array}$ \\
\hline $\mathbf{2 0 0 8}$ & $\begin{array}{l}\text { Mais fácil de se traduzir e clara do que a } \\
\text { antecessora, apresentou maior compatibilidade } \\
\text { com a ISO 14000:2004, e foi considerada mais } \\
\text { consistente com as demais normas ISO 9000 }\end{array}$ \\
\hline $\mathbf{2 0 1 5}$ & $\begin{array}{l}\text { Procurou incentivar a adoção do ciclo PDCA } \\
\text { na organização como um todo, abordou a } \\
\text { supply chain e dedicou foco a análise de risco }\end{array}$ \\
\hline
\end{tabular}

Fonte: Elaborado a partir de ABNT (2015), Arnold (1994, 2004), ISO (2008), Lazarte (2015) e Oliveira e Melhado (2004).

No geral, como pode ser visualizado no Quadro 3, as mudanças que surgiram de uma versão da norma ISO 9001 para outra buscaram: torná-la menos prescritiva e rígida, atender as mudanças que influenciaram a busca pela qualidade dentro das empresas, e fornecer uma linguagem mais clara para o entendimento de seus usuários. Com esse intuito, a ISO 9001 passou por mudanças estruturais que não só exigiram novos requisitos a serem cumpridos por parte das organizações, como também reformularam aqueles já existentes.

\section{CONCLUSÃO}

A qualidade tem se consolidado como um critério qualificador e a normalização um imperativo para produtos e serviços na atualidade. Como exposto pela ABNT (2015), a razão primordial para se realizar as atualizações nas normas é o entendimento de que o cenário no qual as empresas estão inseridas passa por modificações de acordo com o tempo. Assim, as revisões da ISO 9001 assumem um status de garantia de conformidade para com o mercado mundial e a ISO permanece uma ferramenta relevante à promoção da atividade econômica.

A análise entre as versões da ISO 9001 no decorrer do texto possibilita perceber que os fatores indutores que levaram a norma ISO 9001 a passar por atualizações estão relacionados não somente a proposta da ISO de sistematicamente revisar suas normas, mas também aos avanços científicos, tecnológicos e acadêmicos, às melhorias do mercado e às exigências dos usuários. Portanto, o atendimento dos requisitos propostos pela ISO 9001 no SGQ conduz a organização a padronização, indicando seu potencial para produzir com qualidade.

Destaca-se ainda a essencialidade de uma normalização compartilhada entre países como uma referência confiável de boas práticas, em termos de um SGQ, para qualquer que seja a organização. Diante desse cenário, conclui-se que as revisões da ISO 9001 foram necessárias para consolidar a norma como um SGQ sempre proeminente.

\section{REFERÊNCIAS}

ARNOLD, K. L. O guia gerencial para a ISO 9000. Rio de Janeiro: Campos, 1994.

ASSOCIAÇÃO BRASILEIRA DE NORMAS TÉCNICAS. A nova versão da ISO 9001:2015- Sistemas de gestão da qualidade- Requisitos. Boletim ABNT, São Paulo, p. 14-18, novembro/dezembro, 2015. 
BRITISH STANDARDS INSTITUTION. Sobre o BSI. Disponível em: https://www.bsigroup.com/pt-BR/Sobre-oBSI/Nossa-historia/. Acesso em: 20 nov. 2019.

CARPINETTI, L. C. R. Gestão da qualidade: conceitos e técnicas. 2. ed. São Paulo: Atlas, 2012.

CARPINETTI, L. C. R.; MIGUEL, P. A. C.; GEROLAMO, M. C. Gestão da qualidade ISO 9001:2008: princípios e requisitos. 4. ed. São Paulo: Atlas, 2011.

CHAVES, S.; CAMPELLO, M. A qualidade e a evolução das normas série ISO 9000. In: Simpósio de Excelência em Gestão e Tecnologia, 13., 2016, Resende. Anais [...]. Resende: Associação Educacional Dom Bosco, 2016, p. 116

CRESWELl, J. W. Projeto de pesquisa: métodos qualitativo, quantitativo e misto. 2. ed. Porto Alegre: Artmed, 2007.

FERREIRA, J. J. A. Modelos normalizados de sistemas de gestão. In: CARVALHO, M. M.; PALADINI. E. P. (Org.). Gestão da qualidade: teoria e casos. Rio de Janeiro: Campus, 2005. p. 153-186.

FONSECA, L. M. C. M.; DOMINGUES, J. P. ISO 9001:2015 edition: management, quality and value, International Journal for Quality Research, v. 11, n. 1, p. 149-158, 2017.

FONSECA, L. M. C. M.; DOMINGUES, J. P.; MACHADO, P. B.; HARDER, D. ISO 9001:2015 adoption: a multicountry empirical research. Journal of Industrial Engineering and Management, v. 12, n. 1, p. 27-50, 2019.

HAMMES, G.; SOUZA, E. D.; FATTERMANN, D. C.; RODRIGUEZ, C. M. T. Efeito da adesão das certificações ISO 9001 no volume de exportações brasileiras. Revista FSA, Teresina, v. 15, n. 6, p. 168-180, 2018.

HECKERT, C. R.; FRANCISCHINI, P. G.; ROTONDARO R. G. QS-9000: a ISO já não é o bastante. Produção, Belo Horizonte, v. 8, n. 1, p. 5-16, 1998.

INTERNATIONAL ORGANIZATION FOR STANDARDIZATION. Implementation guidance for ISO 9001:2008. Genebra: The International Organization for Standardization, 2008.

\section{INTERNATIONAL ORGANIZATION FOR \\ STANDARDIZATION. ISO 9001:2015: quality} management systems- requirements. Disponível em: https://www.iso.org/standard/62085.html. Acesso em: 25 nov. 2019.

INTERNATIONAL

ORGANIZATION

FOR

STANDARDIZATION. ISO in brief: great things happen when the world agrees. Genebra: The International Organization for Standardization, 2016.

INTERNATIONAL

ORGANIZATION

FOR

STANDARDIZATION. Selection and use of the ISO 9000

family of standards. Genebra: The International Organization for Standardization, 2016.

INTERNATIONAL

ORGANIZATION

FOR

STANDARDIZATION. The ISO Survey of Management System Standard Certifications 2019. Genebra: The International Organization for Standardization, 2020.
LAMBERT, G. A stroll down quality street. ISOFOCUS_123, p. 36-43, julho, 2017. Disponível em: https://qcin.org/nbqp/knowledge_bank/uploads/2018/11/154 1055548_h3.pdf. Acesso em: 15 set. 2020.

LAZARTE, M. ISO 9001:2015 just published. Disponível em: https://www.iso.org/news/2015/09/Ref2002.html. Acesso em: 29 nov. 2019.

MIRANDA, F. J. O impacto da implantação da norma ISO 9001:2008 na gestão de empresas do setor de prestação de serviços. 2014. Dissertação (Programa de PósGraduação em Administração)- Faculdade de Pedro Leopoldo. Fundação Cultural Dr. Pedro Leopoldo, Pedro Leopoldo, 2014.

OLIVEIRA, O. J.; MELHADO, S. B. Nova norma ISO 9000 versão 2000. In: OLIVEIRA, O. J. (Org.). Gestão da qualidade: tópicos avançados. São Paulo: Pioneira Thomson Learning, 2004. p. 57-75.

OST, J.; SILVEIRA, C. G. Avaliação do processo de transição da ISO 9001:2008 para a ISO 9001:2015: um estudo voltado para empresas químicas do estado do Rio Grande do Sul. Gestão \& Produção, São Carlos, v. 25, n. 4, p. 726-736, 2018.

PASTOR-FERNÁNDEZ, A.; OTERO-MATEO, M. Impacto de la norma ISO 9001:2015 en el ámbito de la ingeniería. Integración en las PYMEs. DYNA, v. 91, n. 2, p. 118-121, 2016.

PINTO, S. H. B.; CARVAlHO, M. M. C.; HO, L. L. Implementação de programas de qualidade: um survey em empresas de grande porte no Brasil. Gestão \& Produção, São Carlos, v. 13, n. 2, p. 191-203, 2006.

RIBEIRO, R. L. A. O.; ALMEIDA, N. H. S.; ANSELMO, A.; SARTORI, I. Aplicação de ferramentas da qualidade: um estudo de caso em um setor administrativo do Instituto Federal de Alagoas Campus Satuba. Revista Sodebras [on line], Curitiba, v. 12, n. 135, p. 24-30, 2017.

ROESCH, S. M. A. Projetos de estágio e de pesquisa em Administração: guia para estágios, trabalhos de conclusão, dissertações e estudo de caso. 2. ed. São Paulo: Atlas, 1999.

SAMOHYL, R. W. Controle estatístico de processo e ferramentas da qualidade. In: CARVALHO, M. M.; PALADINI. E. P. (Org.). Gestão da qualidade: teoria e casos. Rio de Janeiro: Campus, 2005. p. 261-299.

SOUSA, M. D.; COSTA-NETO, P. L. O.; GOMES, D. A. O planejamento e os sistemas de gestão como disseminadores da ISO 9001: 2015 em micro e pequena empresa. Revista Sodebras [on line], Curitiba, v. 14, n. 160, p. 78-85, 2019.

STARKE, F.; EUNNI, R. V.; FOUTO, N. M. M. D.; ANGELO, C. F. Impact of ISO 9000 certification on firm performance: evidence from Brazil. Management Research Review, v. 35, n. 10, p. 974-997, 2012.

TAMASHIRO, H. R. S.; HERMOSILLA, J. L. G.; NEVES, M. F. A certificação ISO 9000 como estratégia internacional para a competitividade: um estudo em empresas industriais. Revista de Administração da Unimep, Piracicaba, v. 1, n. 1, p. 82-108, 2003.

UNITED KINGDOM ACCREDITATION SERVICE. Technical bulletin: important further information for 
certification bodies regarding transition to ISO 9001 and ISO

14001. 2018. Disponível em:

https://www.ukas.com/news/technical-bulletin-important-

further-information-for-certification-bodies-regarding-

transition-to-iso-9001-and-iso-14001/. Acesso em: 15 set. 2020 .

VAL, G. T. Os impactos da mudança da ISO 9001:1994 para a ISO 9001:2000 em uma empresa metalúrgica.

2004. Dissertação (Mestrado Profissional em Engenharia Mecânica) - Faculdade de Engenharia Mecânica, Universidade Estadual de Campinas, Campinas, 2004.

VERGARA, W. R.; YAMARARI, J. S.; BARBOSA, F. A. Gestão da qualidade: redução de custos em uma usina sucroenergética. Revista Sodebras [on line], Curitiba, v. 14, n. 168 , p. $48-52,2019$.

\section{COPYRIGHT}

Direitos autorais: Os autores são os únicos responsáveis pelo material incluído no artigo.

Submetido em: 14/09/2020

Aprovado em: 16/10/2020 


\title{
Revista SODEBRAS - Volume 15 \\ $\mathrm{N}^{\circ} 178$ - OUTUBRO/ 2020
}

\section{ECONOMIA CRIATIVA E SUSTENTABILIDADE NA GRANDE CUIABÁ/MT}

\section{CREATIVE ECONOMY AND SUSTAINABILITY IN GRANDE CUIABÁ/MT}

\author{
ANTÔNIO ANANIAS MOTA JÚNIOR ${ }^{1}$; RAQUEL MARTINS FERNANDES²; \\ RODRIGO RIBEIRO DE OLIVEIRA ${ }^{3}$; MARIA GENI PEREIRA BILIO ${ }^{4}$, \\ 1; 4 - UNIVERSIDADE DE CUIABÁ (UNIC), BRASIL; 2 - INSTITUTO FEDERAL DE MATO GROSSO \\ (IFMT), BRASIL; 3 - INSTITUTO FEDERAL DE SÃO PAULO (IFSP), BRASIL \\ engenheirodotrabalhoajr@gmail.com; raquel.fernandes@blv.ifmt.edu.b; rodrigoribeirosp@hotmail.com; \\ genibilioprofessora@gmail.com
}

\begin{abstract}
Resumo - O presente texto aborda um tema contundente $e$ relevante nos dias atuais. A criatividade tem sido palavra de ordem frente à necessidade crescente de mudança $e$ inovação nas organizações. A partir de um levantamento bibliográfico inicial de dados sobre a região metropolitana de Mato Grosso, procurou-se pensar na relação da economia criativa com o bem-estar, sustentabilidade e educação na região. $E$ proposto uma criatividade aliada ao processo de inovação e conhecimento independente se no desenvolvimento ou aprimoramento e para isso será feito um diálogo com Bendassolli et al. (2009) e Marinho et al. (2012). Observou-se, através da pesquisa, que o entretenimento favorece o bem-estar social e fomenta a economia, trazendo rentabilidade ao Estado; constituem processos de sociabilidade e inclusão social. Observa-se que as soluções para as novas exigências de diversidade do mercado consumidor perpassam por uma gestão participativa.
\end{abstract}

Palavras-chave: Desenvolvimento Regional. Sustentabilidade. Interdisciplinaridade Cultural.

Abstract - This text deals with a striking and relevant theme today. Creativity has been the watchword in the face of the growing need for change and innovation in organizations. From an initial bibliographic survey of data on the metropolitan region of Mato Grosso, we tried to think about the relationship between the creative economy and well-being, sustainability and education in the region. It is proposed a creativity combined with the process of innovation and independent knowledge whether in the development or improvement and for that, a dialogue with Bendassolli et al. (2009) and Marinho et al. (2012). It was observed, through the research that entertainment favors social well-being and promotes the economy, bringing profitability to the State; constitute processes of sociability and social inclusion. It is observed that the solutions to the new demands of diversity in the consumer market go through participatory management.

Keywords: Regional Development. Sustainability. Cultural Interdisciplinarity.

\section{INTRODUÇÃO}

$\mathrm{O}$ artigo traz à tona uma discussão sobre um tema relevante que é a inovação/criatividade o que leva a inserção em atividades diversas desenvolvivas no Vale do Rio Cuiabá, desde a Festa de São Benedito ao Festival de Chapada, ambos se utilizam de inovações e muita criatividade para atrair cada vez mais o seu público. Segundo Alencar (1995), as organizações convivem com a necessidade crescente de mudança em todo o tempo, a criatividade é a palavra de ordem para a inovação; os desafios vêem da estrutura da própria organização, de limitações dos indivíduos ou de fatores extraorganizacionais. As soluções para as novas exigências de diversidade do mercado consumidor perpassam por uma gestão participativa, um aproveitamento sistemático da criatividade e uma efetividade nos empreendimentos.

Diante disso, propõe-se fazer um diagnóstico sobre as inovações e sua relação a economia critativa em Mato Grosso, na região do Vale do Rio Cuiabá, instituída pela Lei complementar $\mathrm{n}^{\circ}$ 359, de 27 de maio de 2009, que compreende as cidades de Cuiabá, Acorizal, Várzea, Nossa Senhora do Livramento, Chapada dos Guimarães e Santo Antônio do Leverger, e mais outros sete municípios do entorno Barão de Melgaço, Jangada, Nobres, Nova Brasilândia, Planalto da Serra, Poconé, Rosário Doeste para compreender como estes municípios poderiam se comportar junto às novas exigências da sociedade contemporânea.

Esta pesquisa é um recorte de outra pesquisa mais ampla sobre Direitos Humanos, inclusão e sustentabilidade, cuja relação da economia criativa com o desenvolvimento social, inovação e inovação social, são escopo do presente estudo, aprovado pelo Comitê de Ética em Pesquisa $\mathrm{N}^{\circ}$ Parecer: 3.088.340.

Neste sentido, percebe-se que o entreterimento favorece o bem-estar social e fomenta a economia, trazendo rentabilidade ao Estado; envolvendo os mais diversos ramos de atividades, meio ambiente e espaços diferenciados e alternativos, que constituem processos de sociabilidade e inclusão social, além de formas de interdisciplinariedade cultural e inovação.

A economia criativa pode ser percebida em atividades desenvolvidas em vários contextos, desde as tradições regionais, tais como Festa de São Benedito, comunidade São Gonçalo Beira Rio (pesca, artesanato, tradições como siriri e cururu, turismo, gastronomia); em Cuiabá.

A capital ainda pode contar com outros ambientes, como: Parque Mãe Bonifácia, Parque Tia Nair, Parque das Águas, Parque Massairo Okamura, food trucks, feiras (sendo 51 com funcionamento de terça a domingo em todos os extremos da cidade de Cuiabá), Orla do Porto, eventos (corridas), Arena Pantanal (área gastronômica, passeio ciclísticos, eventos de diferentes nichos, religiões, esportes e lazer para a família de um modo geral), espaços virtuais da influência digital (redes sociais, grupos de relacionamentos, 
marketing digital, aumenta a linha de relacionamentos). Ainda tem o Festival do Inverno, em Chapada dos Guimarães que contribui para o desenvolvimento da região nesse contexto.

Estes espaços de convivência atraem todas as classes sociais (música, comércio, lazer, entreterimento, conhecimento) e quando se usa da criatividade e versatilidade o ser humano faz uma combinação perfeita: inovação, rentabilidade e inclusão social, além de bem-estar para a pessoa que frequenta o local.

De acordo com a Superintendência de Desenvolvimento da Economia Criativa de Mato Grosso: entre junho de 2015 - quando foram iniciadas as discussões acerca da economia criativa na Secretaria de Estado de Cultura e em dezembro de 2016, foram realizadas diversas atividades que contribuíram significativamente para início do desenvolvimento da economia criativa em Mato Grosso, onde, o Estado foi reconhecido nacionalmente por possuir um dos melhores ecossistemas de economia criativa e inovação do Brasil.

Marinho et al. (2012) realizaram uma revisão sistemática, encontrando 40 artigos, publicados no período de 1990 a 2011, abordando a criatividade e a inovação que tornaram-se temas essenciais nos ambientes organizacionais. No artigo os resultados encontrados na pesquisa são apresentados de forma bem didática e de fácil compreensão, através de tabelas e gráficos.

As definições de criatividade encontradas nos artigos, reportam à capacidade, geração de ideias, desejo de criar, processo mental; dentre outros elementos. Destaca-se, do estudo realizado, a análise dos fatores estimuladores e inibidores da criatividade; dos estimuladores foram alencados: Ambiente adequado; Cultura organizacional; Multidisciplinaridade; Interdisciplinaridade; Mudança de rotina; Quebra de padrões e mente aberta; Confiança; Motivação; Autonomia. E dos inibidores: Paradigmas; Conflitos; Pressão para criar; Alto nível de estresse ocupacional; Tensão nos trabalhadores.

De acordo com esta pesquisa, uma grande parcela dos estudos publicados estão atrelados ao ramo da Psicologia. Além disso, verificou-se que as publicações apresentam ligação com a situação do cenário atual do mercado, em que a exigência por qualificação de serviços ou produtos é cada vez maior e a capacidade criativa torna-se gradativamente um diferencial competitivo para as organizações (MARINHO et al. 2012, p. 4). Sabe-se que independente da área de atuação, a criatividade, a proatividade tem lugar de destaque no mundo atual. E que, em qualquer campo de atuação, um empreendimento não se sustentará se não se adequa às inovações impostas pela sociedade e, consequentemente, pelo mercado de trabalho.

Indústrias também tiveram que se renovarem para atender as exigências do mercado consumidor, pois, quem não se adequa perde para a concorrência.

$\mathrm{Na}$ década de 1990, o governo inglês define as indústrias criativas, como as de:

publicidade, arquitetura, mercado de artes e antiguidades, artesanato, design, design de moda, cinema, software, softwares interativos para lazer, música, artes performáticas, indústria editorial, rádio, TV, museus, galerias $\mathrm{e}$ as atividades relacionadas às tradições culturais (BENDASSOLLI et al. 2009, p. 11).
E a partir de estudos econômicos, percebeu-se o crescimento deste segmento. Os autores analisam diversas definições de vários autores para o termo indústrias criativas e percebem que a criatividade, a variedade, o tratamento da cultura como objeto cultural e a noção de propriedade intelectual são elementos que permeiam a definição deste setor.

As premissas que envolvem os negócios neste ramo, referem-se a interrelação entre arte, negócios e tecnologia; além da preponderância dos símbolos e signos sobre produtos materiais. Segundo os autores, a partir dos estudos realizados, é possível perceber três grandes blocos de indústrias criativas; sendo que cada um deles denotam um elemento primordial para o ramo: criatividade (enquanto forma de produção); variedade (como característica do produto); consumo cultural (característica do consumo).

\begin{abstract}
A partir dessas análises e de um exame da literatura, podem-se agrupar as características das indústrias criativas em três grandes blocos: o primeiro bloco refere-se a uma forma de produção que tem a criatividade como recurso-chave, que valoriza a arte pela arte, que fomenta o uso intensivo de novas tecnologias de informação e de comunicação, fazendo uso extensivo de equipes polivalentes; o segundo bloco abrange os contornos específicos dos produtos gerados, tais como a variedade infinita, a diferenciação vertical e a perenidade; e o terceiro bloco representa uma forma particular de consumo, que possui caráter cultural e apresenta grande instabilidade na demanda (BENDASSOLLI et al. 2009, p. 13).
\end{abstract}

A mudança da terminologia de indústria cultural para indústria criativa é associada pelos autores com uma conotação mais positiva da relação a arte, tecnologia e negócios; no entanto, é preciso que haja pesquisas mais aprofundadas, que investiguem os negócios neste ramo e as políticas públicas para verificar se realmente esta mudança terminológica não é apenas uma renovação semântica.

Percebe-se que os dados comprovam que o Estado de Mato Grosso obteve um crescimento considerável nesse segmento de atividade, sendo que dependerá de incentivos governamentais para que avance economicamente.

Ainda neste sentido Eber (2010) afirma que:

Todo e qualquer avanço neste tipo de tecnologia necessita profundos conhecimentos técnicos e científicos a fim de trazer os conhecimentos para o dia a dia da população (EBER, p. 45, 2010).

\section{PROCEDIMENTOS}

Para realização da pesquisa, tendo em vista os limites e possibilidades da mesma, foi realizado um diagnóstico em pesquisa exploratória sobre a região, na fase inicial, para delimitar os locais onde a pesquisa seria realizada e os ramos de atividades. A abordagem é qualitativa, neste estudo apresenta os resultados bibliográficos. Num segundo momento, será realizado um diagnóstico junto aos municípios pertencentes ao Vale do Rio Cuiabá sobre os eventos/atividades direcionadas a inovações/educação criativa que faça a interação entre inovações/trabalho/inclusão social e lazer.

Lakatos (1992), a principal característica da pesquisa bibliográfica ou revisão de literatura é a de proporcionar ao 
pesquisador a aquisição de experiência teórica variada, contribuindo para ampliar o conhecimento.

A pesquisa qualitativa nas ciências sociais se preocupa com o nível de realidade que não pode ser quantificado, dando mais atenção às questões particulares, trabalhando com um universo de significados, ou seja, com a profundidade das relações que não podem ser reduzidos à operacionalização de variáveis (MINAYO, 2001).

A observação se pautou na construção de alguns critérios baseados na diversidade, ou seja, os recortes foram feitos em função da possibilidade de analisar diferentes aspectos, tais como a constituição profissional, formação cultural e situação socioeconômica, índices de desenvolvimento, dentre outros, encontrados nos artigos e textos pesquisados.

\section{RESULTADOS}

Através das pesquisa foi possível perceber a ligação existente entre: economia criativa, inovações, rentabilidade e inclusão social, pois, lugares abertos como: feira, parques, festas culturais, dentre outros que são ambientes que têm o papel de oportunizar às pessoas momentos de inovações, se redescobrindo como empreendedor (para superar a crise), inclusão social - onde é encontrado pessoas de todas as etnias e classes sociais dividindo um mesmo espaço

Os dados do Instituto Brasileiro de Geografia e Estatística - IBGE apontam características do cenário regional, que permitem compreender social e economicamente a economia da região. A tabela 1 abaixo mostra isso.

Tabela 1 - Área, População, IDH e PIB per capita

\begin{tabular}{|c|c|c|c|c|}
\hline 肎 & 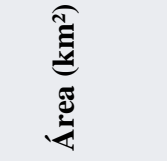 & 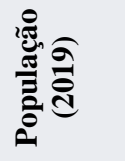 & 鸹 & 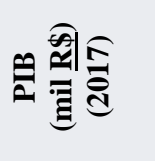 \\
\hline Cuiabá & $3.538,167$ & 612.547 & 0,785 & $39.485,65$ \\
\hline $\begin{array}{l}\text { Várzea } \\
\text { Grande }\end{array}$ & 938,057 & 284.971 & 0,734 & $28.803,94$ \\
\hline $\begin{array}{l}\text { S. Antônio } \\
\text { de Leverger }\end{array}$ & $12.260,081$ & 16.628 & 0,656 & $26.243,48$ \\
\hline $\begin{array}{l}\text { N. Sra do } \\
\text { Livramento }\end{array}$ & $5.192,568$ & 16.628 & 0,656 & $26.243,48$ \\
\hline Acorizal & 841,166 & 5.399 & 0,628 & $13.613,05$ \\
\hline $\begin{array}{l}\text { Barão de } \\
\text { Melgaço }\end{array}$ & $11.182,846$ & 8.564 & 0,600 & $10.768,66$ \\
\hline $\begin{array}{l}\text { Chapada } \\
\text { dos } \\
\text { Guimarães }\end{array}$ & $6.206,573$ & 19.752 & 0,688 & $36.407,06$ \\
\hline Jangada & $1.021,939$ & 8.409 & 0,630 & $33.098,95$ \\
\hline Nobres & $3.859,509$ & 15.336 & 0,699 & $35.303,94$ \\
\hline $\begin{array}{c}\text { Nova } \\
\text { Brasilândia }\end{array}$ & $3.266,215$ & 3.829 & 0,651 & $19.155,48$ \\
\hline $\begin{array}{l}\text { Planalto da } \\
\text { Serra }\end{array}$ & $2.454,108$ & 2.662 & 0,656 & $26.840,63$ \\
\hline Poconé & $17.260,861$ & 32.843 & 0,652 & $15.598,45$ \\
\hline $\begin{array}{l}\text { Rosário } \\
\text { Oeste }\end{array}$ & $8.802,047$ & 17.151 & 0,650 & $16.709,81$ \\
\hline
\end{tabular}

Fonte: IBGE, 2020.

Alguns dados de Cuiabá mostram o contexto da capital, que se torna referência para a pesquisa, os quais são enfatizados, podendo contribuir de forma mais efetiva para compreensão de outras cidades que fazem parte da região do vale do Rio Cuiabá. A Tabela 2 apresenta os valores populacionais em determinado período.

Tabela 2 - Contingente populacional de Cuiabá

\section{POPULAÇÃo}

\begin{tabular}{|c|c|}
\hline População estimada [2019] & 612.547 pessoas \\
\hline $\begin{array}{l}\text { População no último } \\
\text { censo [2010] }\end{array}$ & 551.098 pessoas \\
\hline Densidade demográfica [2010] & $157,66 \mathrm{hab} / \mathrm{km}^{2}$ \\
\hline
\end{tabular}

A Tabela 2, evidencia o contingente populacional em Cuiabá entre 2010 a 2019 foram registrados em 61.449 pessoas, sendo destacado outros aspectos populacionais em tabelas abaixo, onde é percebido o trabalho e rendimento na cidade de Cuiabá.

Tabela 3 - Trabalho e rendimento

\section{TRABALHO E RENDIMENTO}

Salário médio mensal dos trabalhadores formais [2017]

Pessoal ocupado [2017]

População ocupada [2017]

Percentual da população com rendimento nominal mensal per capita de até $1 / 2$ salário mínimo [2017]

Fonte: IBGE, 2020.

A tabela 3, mostrou que o rendimento da maior parte da população brasileira é próximo ou inferior ao salário mínimo determinado pelo governo, evidenciando que a base da pirâmide econômica aumenta ano após ano e o topo diminuindo ainda mais.

Dessas pessoas estão inclusas também àquelas que trabalham na informalidade, que é sabido que nos últimos anos e com o aumento da taxa de desemprego teve um aumento considerável. Segundo os levantamentos do IBGE, o salário médio mensal em 2017, era de 4 (quatro) salários mínimos.

Em 2017, o salário médio mensal era de 4 (quatro) salários mínimos. A proporção de pessoas ocupadas em relação à população total era de $44.0 \%$. Na comparação com os outros municípios do estado, ocupava as posições 1 de 141 e 2 de 141, respectivamente. Já na comparação com cidades do país todo, ficava na posição 30 de 5570 e 112 de 5570 , respectivamente. Considerando domicílios com rendimentos mensais de até meio salário mínimo por pessoa, tinha $30.7 \%$ da população nessas condições, o que o colocava na posição 134 de 141 dentre as cidades do estado e na posição 4549 de 5570 dentre as cidades do Brasil.

A Tabela 4, demonstra os percentuais econômicos gerais da cidade de Cuiabá em 2017 onde a diferença entre a receita e a despesa se registra em 110.086,81 R \$ (x1000) em 2017. 
Tabela 4 - Economia (Cuiabá/MT)

\section{ECONOMIA}

PIB per capita [2017]

$39.485,65 R \$$

Percentual das receitas oriundas de fontes externas [2015]

Índice de Desenvolvimento Humano Municipal (IDHM) [2010]

$55,2 \%$

0,785

Total de receitas realizadas [2017]

2.153.678,78R

$\$(\times 1000)$

2.043.591,97

Total das despesas empenhadas [2008]

$\mathrm{R} \$(\times 1000)$

Fonte: IBGE, 2020.

A Secretaria de Estado de Cultura de Mato Grosso possui uma Superintendência de Desenvolvimento da Economia Criativa, que tem como missão desenvolver o setor. Segundo esta superintendência, o estado de Mato Grosso tem apresentado crescimento nesta área e se destacado no Brasil.

Vale ressaltar que o termo - Economia Criativa conceitua modelos de negócios ou gestão que se originam em atividades, produtos ou serviços tendo como principal recurso produtivo a criatividade, o capital intelectual e o valor simbólico-cultural. Estes produzem valor econômico e são reconhecidos mundialmente como estratégia para a redução da desigualdade social, pois geram emprego e renda, também aparecem como um importante eixo para promover atividades em rede. Seguem as principais atividades desenvolvidas pela Superintendência de Desenvolvimento da Economia Criativa entre junho de 2015 e dezembro de 2016. Elas atingiram um público estimado de 7.000 pessoas

Há notoriamente o incentivo a um desenvolvimento sustentável na área da economia criativa no Estado de Mato Grosso, o que produz rentabilidade, bem-estar e inclusão social.

A política de incentivo do Governo do Estado para o setor inclui o estímulo a pequenos empresários do ramo joalheiro, dentro do programa de Economia Criativa que vem sendo desenvolvido pela Secretaria de Estado de Desenvolvimento Econômico (Sedec), que abrange setores como moda, design, artes e gastronomia. Há 30 anos no mercado de joias em Cuiabá, Carmem D'Lamonica vê Mato Grosso como um futuro polo joalheiro pela abundância de pedras coradas existentes no solo mato-grossense e até então pouco exploradas. Destaca-se que a matéria-prima atrai não apenas joalheiros, mas também indústrias de semi jóias e bijuterias.

O Arranjo Produtivo Local (APL) de Economia Criativa do Vale do Rio Cuiabá constitui de exemplo de um projeto aprovado em edital do Ministério do Desenvolvimento, Indústria e Comércio Exterior (Mdic) em 2015, com duração de dois anos, que teve como objetivo fomentar a cadeia produtiva da cultura na região. A meta do projeto é construir uma rota turístico-cultural, em que o turista conheça o melhor de Mato Grosso. Segundo gestores da área cultural de Mato Grosso, investimentos da economia criativa tem retorno imediato para toda comunidade $\mathrm{e}$ também para os turistas.

O Secretário de Estado de Cultura, Fabiano Prates, destacou a importância do APL para o fomento e a preservação de manifestações culturais como o cururu e o siriri, cartões de visita do Estado. "O mais importante é fomentar estas manifestações, não deixá-las morrer. Mato Grosso fica muito feliz com este presente. E nós também, ao entregarmos a pasta de Cultura com os recursos necessários para que esse projeto aconteça". (...) A presidente do Comitê Gestor do APL, Cínthia Mattos, salientou não se tratar de uma ação de governo, mas sim de toda a sociedade, conclamando os atores sociais principais - os artistas e parceiros - para que continuem contribuindo. "Temos uma cultura pujante e belezas naturais riquíssimas, agora só falta mostrá-las. Para isso é preciso contar com a parte mais importante, que são os atores sociais. Com o APL, poderemos dinamizar estes setores e oferecer como produto final um roteiro completo a quem aqui vier. Queremos que o turista tenha condições de usufruir da Maria Izabel, da viola de cocho, dos quintais de siriri, da casa cuiabana, das belezas do Pantanal, enfim, de tudo o que o Estado tem a oferecer em termos de turismo e cultura". Cínthia é coordenadora de ações artístico-culturais da SEC-MT.

Observando a composição do APL, percebe-se a articulação do segmento cultural em Mato Grosso e como o mesmo atende ao desenvolvimento sustentável e regional: Associação Flor; Associação Morielo São Gonçalo Beira Rio, Associação de Artesãos São Gonçalo Beira Rio; Associação Cururueiro Coxipó São Francisco; SICME/PAB (Programa Artesanato Brasileiro), Centro Histórico Cultural Holístico (CCH); Associação Quintal; Peixaria Coxipó São Geraldo Beira Rio, AMAV/ABD-MT; Cia das Artes do Brasil; Secretaria de Estado de Cultura; Federação de Cururu e Siriri; TV AL-MT; Unic Gastronomia; Ponto de Cultura; SEDRAF (Secretaria de Estado de Desenvolvimento Rural e Agricultura Familiar - Sedraf), CIDES-URC; Secretaria de Estado de Desenvolvimento do Turismo (SEDTUR); Secretaria de Estado de Meio Ambiente (SEMA); Secretaria de Estado de Trabalho e Assistência Social (SETAS-MT); Nobres Vozes; APPA; Grupo Cururu e Siriri Raízes Cuiabanas; Associação Mato-grossense dos Cegos; Ponto de Cultura Instituto dos Cegos; Trade Turístico; JY Okamura Assessoria e Consultoria, Lamiré Cinema e Vídeo e Instituto Ecoss.

A cultural regional é outro aspecto que a economia criativa fomenta, o mestre cururueiro Benedito Pinto de Moraes (coordenador do Grupo Folclórico de Cururu, Siriri e Reza Cantada do Pantanal).

São precisos pelo menos seis meses para se formar um novo cururueiro, sentimos a dificuldade em ter infraestrutura para repassar aos nossos jovens este conhecimento. Sem investimento, a dança tradicional, os costumes tendem a morrer. Esperamos que com este investimento, possamos crescer cada vez mais no Estado.

Antônio João Batista Campos de Arruda, o Tote, um dos representantes da dança do Congo: "Esta dança é a manifestação de nossos ancestrais africanos. Lutamos por sua preservação".

\section{CONCLUSÃO}

A pesquisa possibilitou conhecer a economia criativa e suas possibilidades de desenvolvimento da região doVale do Rio Cuiabá. Percebe-se que as atividades desenvolvidas nesse contexto promove e envolve muito além da economia criativa, onde a criatividade, inovações fazem parte de campo de atuação.

No Estado de Mato Grosso foi observado uma combinação entre entretenimento, inclusão social e ainda 
fomenta a economia trazendo assim, rentabilidade, envolvendo os diversos ramos de atividades e constituem processos de socialização e inclusão social por meio da interdisciplinariedade cultural e inovações.

Até o momento foi possível observar que o entretenimento favorece o bem-estar social e fomenta a economia, trazendo rentabilidade ao Estado; envolvendo ramos de atividades dos mais diversos, meio ambiente e espaços diferenciados e alternativos, que constituem processos de sociabilidade e inclusão social, além de formas de interdisciplinariedade cultural e inovação.

Foi possível perceber que as soluções para as novas exigências de diversidade do mercado consumidor perpassam uma gestão participativa, um aproveitamento sistemático da criatividade e uma efetividade nos empreendimentos.

Mato Grosso é um Estado de muitas belezas naturais e o turismo precisa se desenvolver com mais efetividade e responsabilidade sustentável, sendo que se faz necessário uma articulação do segmento cultural no Estado que atenda ao desenvolvimento sustentável e regional e promova o crescimento dessa área da economia criativa com inovações, diversidade cultural, sustentabilidade e inclusão social na região do vale do rio Cuiabá.

No entanto, ainda necessita de um trabalho mais efetivo nesta área para que possa haver um desenvolvimento mais efetivo e consistente; para isso faz-se necessária a criação de políticas públicas e incentivos atrativos para que tragam novos colaboradores/investidores nesta área da economia criativa.

\section{REFERÊNCIAS}

ALENCAR, E. L. S. Desenvolvendo a Criatividade nas Organizações: o Desafio da Inovação. RAE - Revista de Administração de Empresas São Paulo, 1995.

BENDASSOLLI, P. F.; WOOD JR., T.; Kirschbaum, C.; Cunha, M. P. Indústrias Criativas: Definição, Limites e Possibilidades. RAE, São Paulo, 2009.

GEVEHR, D. L. \& BRAUN, J. L. Tecendo Memórias, Preservando O Passado E Desenvolvendo O Agora: Museus, Memória e Patrimônio Cultural no Contexto da Economia Criativa. PRACS: Revista Eletrônica de Humanidades do Curso de Ciências Sociais da UNIFAP, Macapá, v. 13, n. 1, p. 31-41, jan./abr., 2020

IBGE - Instituto Brasileiro de Geografia e Estatística. (2020). Brasil, Mato Grosso, Panorama. Disponível em: https://cidades.ibge.gov.br/brasil/mt/cuiaba/panorama.

Acesso em 29 de maio de 2020.

LAKATOS, M.E. MARCONI, M.A Metodologia do Trabalho Científico. $4^{\mathrm{a}}$ ed. revista e ampliada. São Paulo: Atlas, 1992.

MINAYO, M.C.S. Pesquisa Social. Teoria, método e criatividade. 18 ed. Petrópolis, RJ: Vozes, 2001.

MARINHO, E. S.; FAGUNDES, L. F.; SILVA, M. S. A.; SQUIRES, M.; GONZALEZ, A. O. A. Relação entre criatividade e inovação de produtos: uma revisão bibliográfica sistemática. Anais... XXXII ENCONTRO NACIONAL DE ENGENHARIA DE PRODUCAO. Desenvolvimento Sustentável e Responsabilidade Social: As
Contribuições da Engenharia de Produção Bento Gonçalves, RS, Brasil, 2012.

MATO GROSSO. Economia. s.d. Disponível em: http://www.mt.gov.br/economia. Acesso em 07 de janeiro de 2018.

MATO GROSSO. LEI COMPLEMENTAR N ${ }^{\circ} 359$, DE 27 DE MAIO DE 2009. (2009).Palácio Paiaguás, em Cuiabá, 27 de maio de $2009,188^{\circ}$ da Independência e $121^{\circ}$ da República. Disponível em: http://app1.sefaz.mt.gov.br/Sistema/legislacao/LeiComplEst adual.nsf/9733a1d3f5bb1ab384256710004d4754/9fcbd862a a45ffa8042575c40046cb9d?OpenDocument. Acesso em 29 de maio de 2020.

MATO GROSSO. (2018). Programa de Desenvolviemnto de Economia Criativa. s.d. Disponínel em: http://mtcriativo.mt.gov.br/images/RELATORIO_Economi a_Criativa.pdf. Acesso em 08 de janeiro de 2018.

MATO GROSSO. Secretaria de Estado de Cultura, Esporte e Lazer. (2014). APL da Economia Criativa é apresentado em Cuiabá. Disponível em: http://www.cultura.mt.gov.br/-/aplda-economia-criativa-e-apresentado-em-cuiaba. Acesso em 08 de janeiro de 2018.m

MESSIAS, F., NASCIMENTO, E., \& SILVA, C. A economia criativa na arena da sustentabilidade. Pós. Revista do Programa de Pós-Graduação em Arquitetura e Urbanismo da FAUUSP, 27(50), e161954. https://doi.org/10.11606/issn.23172762.posfau.2020.161954, 2020.

STAKE, R. E. A arte da Investigação com Estudo de Caso. Lisboa. Fundação Calouste Gulbenkian, 2000.

\section{COPYRIGHT}

Direitos autorais: Os autores são os únicos responsáveis pelo material incluído no artigo.

Submetido em: 10/09/2020 Aprovado em: 10/10/2020 


\section{Área: Ciências Agrárias e Biológicas}

\begin{tabular}{|l|l|}
\hline $4-2$ & $\begin{array}{l}\text { EPIDEMIOLOGICAL PROFILE OF MAXILLOFACIAL TRAUMA IN A TEACHING } \\
\text { HOSPITAL IN BRAZIL } \\
\text { Rodrigo Lemos Alves; Izabelly Linhares Ponte Brito; Vicente De Paulo Teixeira Pinto; } \\
\text { Francisco Cesar Barroso Barbosa }\end{array}$ \\
\hline
\end{tabular}




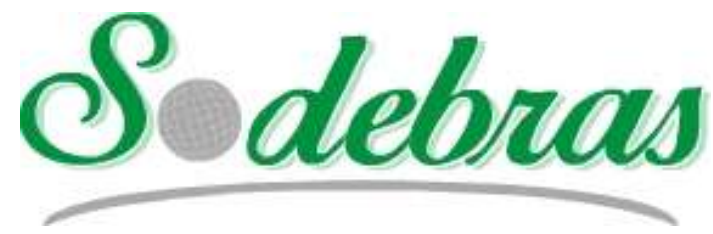

\author{
Revista SODEBRAS - Volume 15 \\ $\mathrm{N}^{\circ} 178$ - OUTUBRO/ 2020
}

\title{
EPIDEMIOLOGICAL PROFILE OF MAXILLOFACIAL TRAUMA IN A TEACHING HOSPITAL IN BRAZIL
}

\author{
RODRIGO LEMOS ALVES ${ }^{1,2}$; IZABELLY LINHARES PONTE BRITO ${ }^{1,2}$; VICENTE DE PAULO \\ TEIXEIRA PINTO' ${ }^{2}$;RANCISCO CESAR BARROSO BARBOSA ${ }^{2}$ \\ 1 - SANTA CASA DE MISERICÓRDIA DE SOBRAL- CEARÁ; 2 - PROGRAMA DE PÓS-GRADUAÇÃO \\ EM CIÊNCIAS DA SAÚDE/UNIVERSIDADE FEDERAL DO CEARÁ - CAMPUS SOBRAL \\ rodrigolemosbmf@gmail.com; izabelly.ponte@stacasa.com.br; pintovicente@gmail.com;
} fcbbarbosa@yahoo.com.br

\begin{abstract}
The aim of this study was to evaluate the epidemiological profile of maxillofacial trauma in a teaching hospital in Ceará-Brazil from 2003 to 2017. A cross-sectional epidemiological study was performed, and 1,087 medical recordings of patients that underwent surgical treatment for facial trauma were evaluated. The most causative factor of facial trauma was motorcycle accident, being it strongly associated with patients up to 39 years of age $(p<0.05)$. Simple fracture on the mandibular bone was the most prevalent injury. Polytraumatized patients remained for longer times in the hospital and were more frequently affected by nosocomial infection $(p<0.05)$. The results suggest that the bucomaxillofacial surgeon has an important role in the emergency of a hospital and that the work of such professional might contribute to the understanding of the main causes of facial trauma.
\end{abstract}

Keywords: Epidemiology. Craniocerebral Trauma. Cross infection. Surgery Oral.

\section{INTRODUCTION}

Maxillofacial trauma is defined as any physical injury affecting the face and its structures (skin, fat tissue, bones, muscles, nerves). It can be identified as an isolated lesion or in association with injuries in other parts of the body. Maxillofacial trauma is considered a condition of bad prognosis due to its aesthetic, functional, and psychological consequences (MOURA, DALTRO, ALMEIDA, 2016; SIKORA et al., 2019; MARSICANO et al., 2019).

The etiology of maxillofacial trauma is diverse and varies according to age, the region where the victims live, socioeconomic status, and culture. Among the main causes of facial trauma are automotive accidents, physical injuries of urban violence, work, and sportive accidents (MOURA, DALTRO, ALMEIDA, 2016; MARSICANO et al., 2019).

In the literature, there are several epidemiological reports of facial trauma (ALVES et al., 2014; ANVISA, 2017; BONAVOLONTÀ et al., 2017; MARSICANO et al., 2019; SIKORA et al., 2020;). These studies emphasize that the epidemiology of such type of trauma also varies in etiology, type, frequency, and severity according to where and when the occurrence of the trauma was studied since geographic, economic, and cultural factors influence the life dynamics of a population in the entire world (ALVES et al., 2014; MOURA, DALTRO, ALMEIDA, 2016).

The severity of the lesions of facial trauma has brought light to the urgent necessity of planning in terms of preventive strategies. Health education and preventive campaigns related to the creation of more severe transportation laws are strategies commonly used to change the perspectives of automotive accidents that might lead to facial trauma. Under this light, tools have been created to ensure the protection of the population while driving or traveling, such as the safety belt, airbags, and lateral bars, which has decreased the incidence and complexity of facial trauma (CARVALHO FILHO et al., 2015).

Therefore, we consider relevant to determine the epidemiological profile of maxillofacial trauma in a teaching hospital of Sobral - Ceará, Brazil, which is a high complexity health center. Thus, we evaluated the frequency of occurrence and severity, and in cases of nosocomial infection associated with facial trauma, we also investigated the main microorganisms involved.

\section{MATERIAL AND METHODS}

This study was approved by the Research and Ethics Committee of the Universidade Estadual Vale do Acarau ( ${ }^{\circ}$ 2.890.895). A cross-sectional epidemiological study was performed, and 1,087 medical recordings of patients that underwent chirurgical treatment for facial trauma during the period from January 2003 to December 2017 were evaluated. Characteristics such as gender, age, type and site of trauma, etiology, the presence of nosocomial infection and type of microorganism involved in the infection were considered.

We only evaluated the medical recordings of the patients that were surgically treated by the Equip of Oral Maxillofacial Trauma of the hospital in which this study was performed. Those medical recordings of patients treated by other specialists were not included, as well as we did not consider the recordings that were damaged or unreadable.

The main etiological agents for the traumatisms were categorized as follows: automotive accident, motorcycle accident, bicycle accident, physical injury, gun injury, sportive accident, fall from own height, the accident with animals, and non-identified agents.

The localization of the facial fractures was classified as follows: intra-buccal, chin, maxillary, zygomatic, nasal, peri-orbital, frontal, temporomandibular joint, and nonspecified fractures. The cases were categorized according to the age of the patients: 0 to 19,20 to 39,40 to 59 and more than 60 years old.

Facial trauma was also classified per type: trauma affecting only soft tissue, multiple fractures, and simple 
fracture. In those in which nosocomial infection was present, the causative microorganism was identified.

The data were analyzed using Fisher's exact test and Pearson's Chi-square Test with the software Statistical Package for the Social Sciences (SPSS), version 20.0 for Windows adopting a significance level of $95 \%$.

\section{RESULTS}

After evaluation of the inclusion and exclusion criteria, we obtained a sample of 1,087 medical recordings of patients who suffered from facial trauma. Regarding gender, we observed that men $(n=913 ; 84 \%)$ were more affected by facial trauma than women $(\mathrm{n}=174 ; 16 \%)$, which represented a rate of 5:1. In terms of age, facial trauma was more prevalent in those aging 20 to 39 years old, followed by those aging from 40 to 59 years old, which accounted for 624 and 342 cases and represented $57.4 \%$ and $31.5 \%$ of our sample, respectively (Table 1).
Among the main etiologies of facial trauma were motorcycle accidents, accounting for 728 cases (67\%), followed by physical injury and automotive accident, which comprised $58(5.3 \%)$ and $55(5 \%)$ cases, respectively (Table 1).

Regarding the type of facial trauma, the majority of cases were classified as simple fractures $(n=781 ; 71.8 \%)$. Also, we observed $65(6 \%)$ cases of soft tissue injuries, 183 $(16.8 \%)$ cases of multiple fractures, and $58(5.4 \%)$ cases in which the type of trauma was not identified in the medical recordings of the patients (Table 1).

The most prevalent fractures were the ones of the mandibular bone, with 453 cases $(41.6 \%)$, followed by the ones of the zygomatic and maxillary bones, accounting for $282(26 \%)$ and $144(13.2 \%)$ cases, respectively. Other facial bones were also affected by facial trauma, but at a smaller rate, as it is shown in Table 1.

Table 1 - Association between the frequency of facial trauma and the independent variables

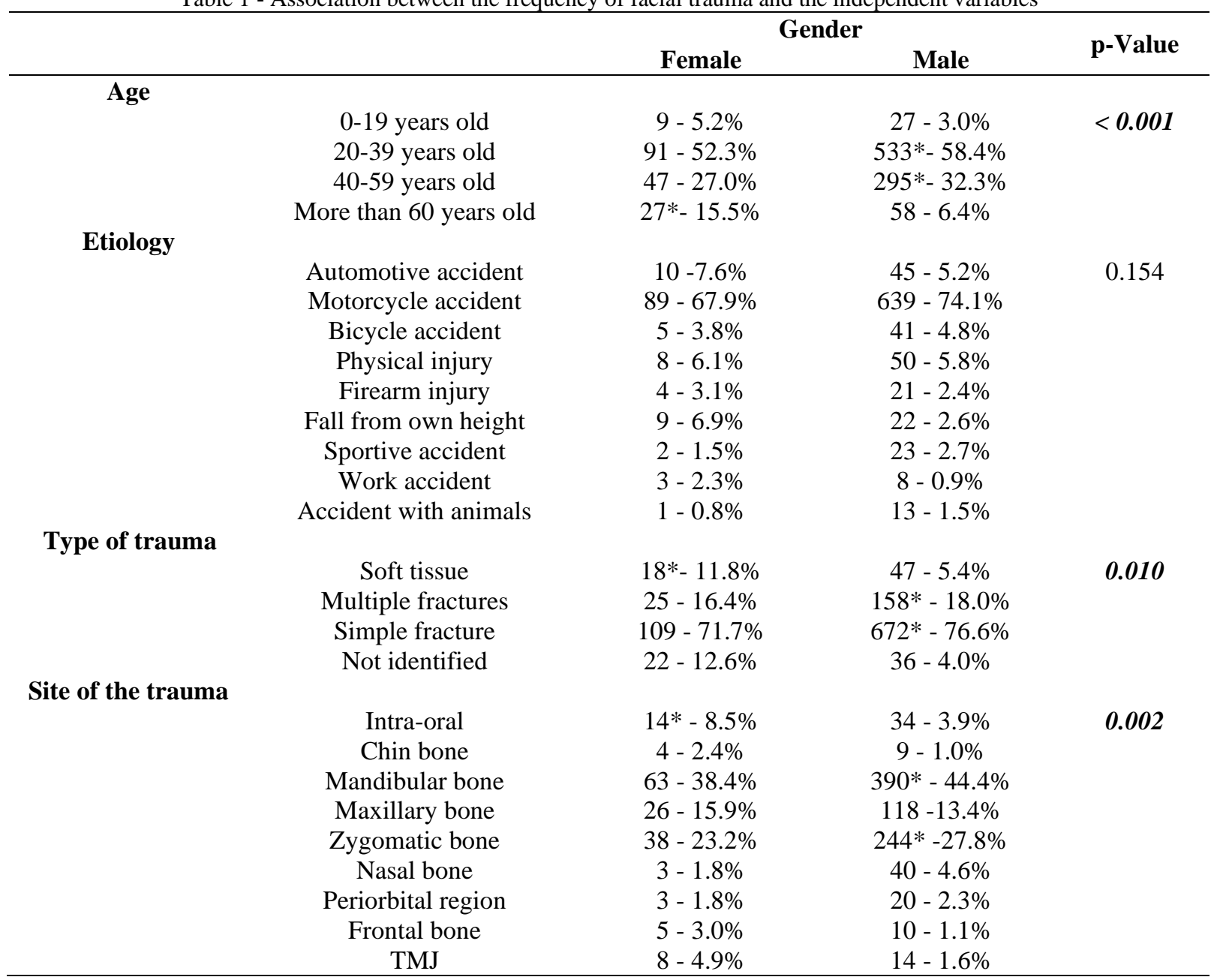

$* p<0.05$. Fisher's Exact Test or Pearson's Chi-squared Test.

Data expressed in absolute frequency and percentage.

Source: Authors, 2020.

Statistically, a significant association was observed when analyzing gender age, with facial trauma at age 20 to 39 years old being more associated with men and more associated with women at the age 60 years old $(\mathrm{p}<0.05)$. Regarding etiology, it was not found a significative association of facial trauma with any of the causative agents studied. When evaluating the association of type of trauma and gender, we found that soft tissue injuries were more associated with females, while all the other types of trauma were associated with male patients $(p<0.05)$. Moreover, intra-oral fractures were more prevalent in female patients, 
while in men, the mandible and zygoma were the sites more frequently affected by trauma $(\mathrm{p}<0.05)$.

Our results also show that nosocomial infection was present in only 46 cases $(4.2 \%)$. The presence of infection was confirmed by the Commission of Control of Nosocomial infection of the hospital in which the study was performed. After, confirming the infection, samples of 9 patients were cultured and analyzed for the identification of the microorganisms involved and to study the antibiogram of such cultures. Among the 9 patients examined, 7 were infected with Staphylococcus sp. and two with Prevotella sp.
Table 2 depicts the results of the association between the etiology of the facial traumatism with the age of the patients. It shows that traffic accidents presented a significative association with facial trauma between patients up to 39 years of age ( $p$ 0.05). Fall from the own height and sportive accidents, on the other hand, were more associated with patients older than 39 years old who also presented intra-oral lesions $(p<0.05)$. No association was found among the etiology of the facial trauma, the presence of infection and time during which the patient remained on the hospital.

Table 2 - Association between the etiology agents of facial trauma

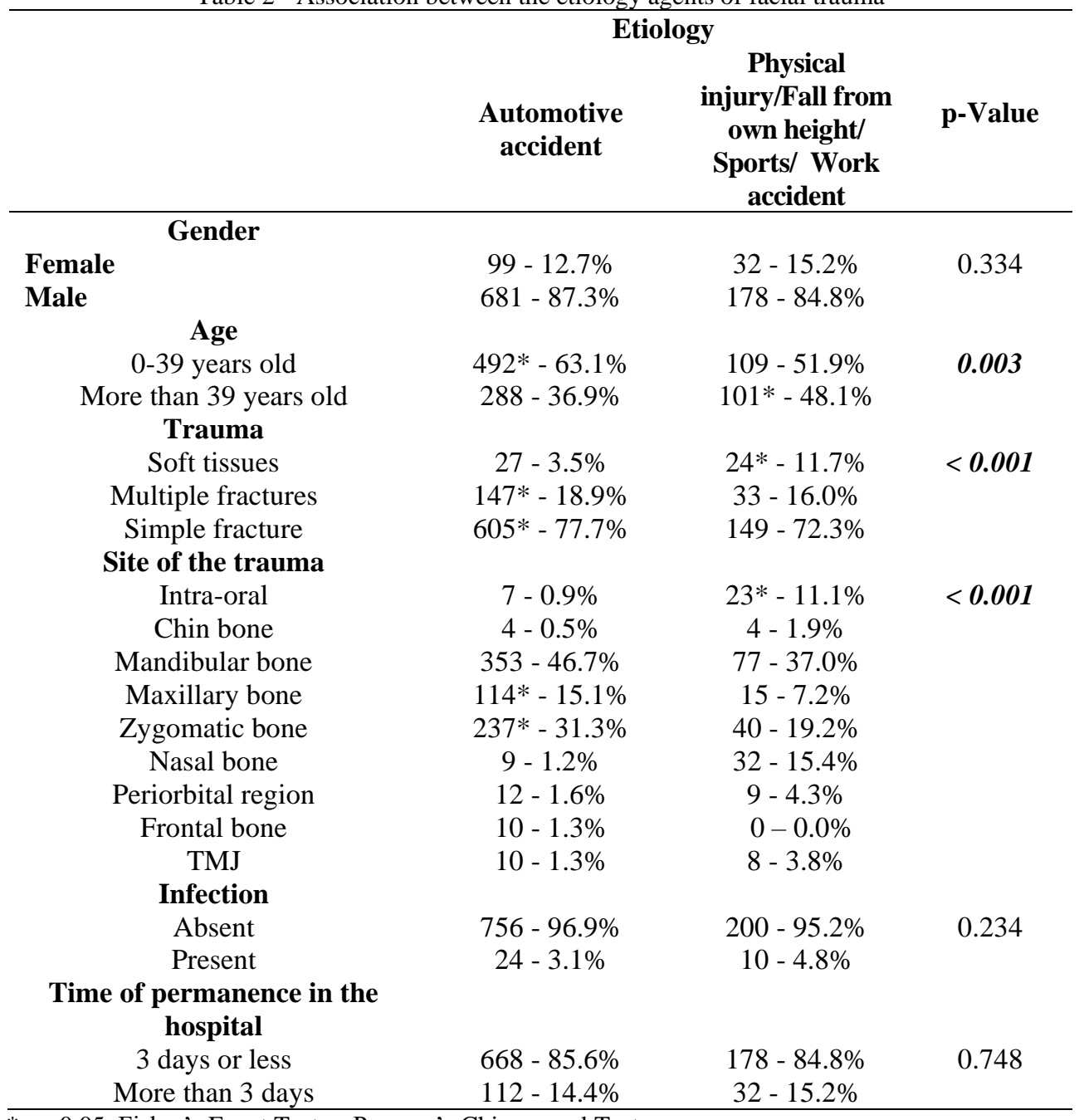

$* p<0.05$. Fisher's Exact Test or Pearson's Chi-squared Test.

Data expressed in absolute frequency and percentage and the independent variables

Source: Authors, 2020

Moreover, we also found that infection was more associated with female patients who had suffered facial trauma involving multiple intra-oral bones and chin and with a longer hospital stay $(\mathrm{p}<0.05)$. The mean time of hospital stay at the teaching hospital was $3.1 \pm 0.7$ days, with a statistically significant association between shorter hospitalization time and individuals up to 39 years of age who presented simple fractures and soft tissue traumas $(\mathrm{p}<$ 0.05) (Table 3). 
Table 3 - Association among nosocomial infection, time of permanence in the hospital, and independent variables

\begin{tabular}{|c|c|c|c|c|c|c|}
\hline & \multicolumn{2}{|c|}{ Infection } & \multirow[t]{2}{*}{ p-Value } & \multicolumn{2}{|c|}{$\begin{array}{l}\text { Time of permanence in the } \\
\text { hospital }\end{array}$} & \multirow[t]{2}{*}{ p-Value } \\
\hline & Absent & Present & & 3 days or less & More than 3 days & \\
\hline \multicolumn{7}{|l|}{ Gender } \\
\hline Female & $161-15.5 \%$ & $13^{*}-28.3 \%$ & 0.021 & $150-16.2 \%$ & $24-15.1 \%$ & 0.734 \\
\hline $\begin{array}{l}\text { Male } \\
\text { Age }\end{array}$ & $880 *-84.5 \%$ & $33-71.7 \%$ & & $778-83.8 \%$ & $135-84.9 \%$ & \\
\hline 0-39 years old & $635-61.0 \%$ & $25-54.3 \%$ & 0.366 & $577 *-62.2 \%$ & $83-52.2 \%$ & 0.017 \\
\hline $\begin{array}{l}\text { More than years old } \\
\text { Etiology }\end{array}$ & $406-39.0 \%$ & $21-45.7 \%$ & & $351-37.8 \%$ & $76 *-47.8 \%$ & \\
\hline $\begin{array}{c}\text { Automotive/ } \\
\text { Motorcycle accident }\end{array}$ & $756-79.1 \%$ & $24-70.6 \%$ & 0.234 & $668-79.0 \%$ & $112-77.8 \%$ & 0.748 \\
\hline $\begin{array}{l}\text { Physical injury/Fall } \\
\text { from own }\end{array}$ & $200-20.9 \%$ & $10-29.4 \%$ & & $178-21.0 \%$ & $32-22.2 \%$ & \\
\hline \multicolumn{3}{|l|}{ Trauma } & \multicolumn{4}{|c|}{ height/Sports } \\
\hline $\begin{array}{l}\text { Simple fracture/ soft } \\
\text { tissue injury }\end{array}$ & $823 *-83.0 \%$ & $23-60.5 \%$ & $<0.001$ & $746^{*}-84.7 \%$ & $100-67.6 \%$ & $<0.001$ \\
\hline Multiple fractures & $168-17.0 \%$ & $15^{*}-39.5 \%$ & & $135-15.3 \%$ & $48 *-32.4 \%$ & \\
\hline \multicolumn{7}{|l|}{ Site of the trauma } \\
\hline Intra-oral & $42-4.2 \%$ & $6^{*}-14.3 \%$ & $<0.001$ & $43-4.8 \%$ & $5-3.5 \%$ & 0.103 \\
\hline Chin bone & $10-1.0 \%$ & $3 *-7.1 \%$ & & $12-1.3 \%$ & $1-0.7 \%$ & \\
\hline Mandíbular bone & $433-43.3 \%$ & $20-47.6 \%$ & & $407-45.2 \%$ & $46-32.4 \%$ & \\
\hline Maxillary bone & $139-13.9 \%$ & $5-11.9 \%$ & & $116-12.9 \%$ & $28-19.7 \%$ & \\
\hline Zygomatic bone & $278 *-27.8 \%$ & $4-9.5 \%$ & & $234-26.0 \%$ & $48-33.8 \%$ & \\
\hline Nasal bone & $43 *-4.3 \%$ & $0-0.0 \%$ & & $37-4.1 \%$ & $6-4.2 \%$ & \\
\hline Periorbital region & $20-2.0 \%$ & $3-7.1 \%$ & & $20-2.2 \%$ & $3-2.1 \%$ & \\
\hline Frontal bone & $14-1.4 \%$ & $1-2.4 \%$ & & $12-1.3 \%$ & $3-2.1 \%$ & \\
\hline TMJ & $22-2.2 \%$ & $0-0.0 \%$ & & $20-2.2 \%$ & $2-1.4 \%$ & \\
\hline \multicolumn{7}{|l|}{$\begin{array}{l}\text { Time of permanence } \\
\text { in the hospital }\end{array}$} \\
\hline 3 days or less & $898 *-86.3 \%$ & $30-65.2 \%$ & $<0.001$ & & - & - \\
\hline More than 3 days & $143-13.7 \%$ & $16 *-34.8 \%$ & & & - & \\
\hline
\end{tabular}

*p $<0.05$. Fisher's Exact Test or Pearson's Chi-squared Test.

Data expressed in absolute frequency and percentage.

Source: Authors, 2020.

Our results also show in Table 4 that motorcycle However, no significative association was found among accidents, firearm injury, and sportive accidents were the type of trauma, site of the traumatism, and infection. main cause of facial trauma in patients up to 39 years of age.

Table 4 - Association between age and independent variables

\begin{tabular}{|c|c|c|c|}
\hline & \multicolumn{2}{|c|}{ Age } & \multirow{2}{*}{ p-Value } \\
\hline & 39 years old or less & More than 39 years old & \\
\hline \multicolumn{4}{|l|}{ Gender } \\
\hline Female & $100-15.2 \%$ & $74-17.3 \%$ & 0.339 \\
\hline Male & $560-84.8 \%$ & $353-82.7 \%$ & \\
\hline \multicolumn{4}{|l|}{ Etiology } \\
\hline Automotive accident & $24-4.0 \%$ & $31 *-8.0 \%$ & $<0.001$ \\
\hline Motorcycle accident & $471 *-78.0 \%$ & $257-66.1 \%$ & \\
\hline Bicycle accident & $26-4.3 \%$ & $20-5.1 \%$ & \\
\hline Physical injury & $31-5.1 \%$ & $27-6.9 \%$ & \\
\hline Firearm injury & $19 *-3.1 \%$ & $6-1.5 \%$ & \\
\hline Fall from own height & $4-0.7 \%$ & $27 *-6.9 \%$ & \\
\hline Sportive accident & $20 *-3.3 \%$ & $5-1.3 \%$ & \\
\hline Work accident & $3-0.5 \%$ & $8 *-2.1 \%$ & \\
\hline Accident with animals & $6-1.0 \%$ & $8-2.1 \%$ & \\
\hline \multicolumn{4}{|l|}{ Trauma } \\
\hline Soft tissues & $44-7.0 \%$ & $21-5.2 \%$ & 0.075 \\
\hline Multiple fractures & $99-15.8 \%$ & $84-20.9 \%$ & \\
\hline Simple fracture & $484-77.2 \%$ & $297-73.9 \%$ & \\
\hline \multicolumn{4}{|l|}{ Site of the trauma } \\
\hline Intra-oral & $35-5.4 \%$ & $13-3.3 \%$ & 0.253 \\
\hline
\end{tabular}




\begin{tabular}{ccc} 
Chin bone & $11-1.7 \%$ & $2-0.5 \%$ \\
Mandíbular bone & $274-42.5 \%$ & $179-44.9 \%$ \\
Maxillary bone & $87-13.5 \%$ & $57-14.3 \%$ \\
Zygomatic bone & $172-26.7 \%$ & $110-27.6 \%$ \\
Nasal bone & $28-4.3 \%$ & $15-3.8 \%$ \\
Periorbital region & $17-2.6 \%$ & $6-1.5 \%$ \\
Frontal bone & $10-1.6 \%$ & $5-1.3 \%$ \\
TMJ & $10-1.6 \%$ & $12-3.0 \%$ \\
Infection & & \\
Absent & $635-96.2 \%$ & $406-95.1 \%$ \\
Present & $25-3.8 \%$ & $21-4.9 \%$ \\
\hline *p $<0.05$. Fisher's Exact test or Pearson's Chi-squared Test. \\
Data expressed in absolute frequency and percentage.
\end{tabular}

Source: Authors, 2020.

\section{DISCUSSION}

Firstly, our study demonstrated that the majority of the patients with facial traumatism who were treated at the Santa Casa de Misericórdia de Sobral were men, which is a finding that agrees with what the literature has already stated (CERQUEIRA et al., 2010; CAVALCANTE et al., 2012; CARVALHO FILHO et al., 2015; MARSICANO et al., 2019; SIKORA et al., 2020).

Regarding age, we showed that the most affected were those in their second and fourth life decades, which also corroborates with the literature (JAN et al., 2015; MARSICANO et al., 2019). Such finding is explained due to characteristics of the social life of people at this age, once they are more prone to abusively use drugs such as alcohol, which is risky, mainly in association with driving.

Moreover, we did not observe a high prevalence of facial trauma in children and in older people, which is justified by the fact that these groups are carefully assisted by their families, they remain for logger times at home and are less involved in sportive and social activities. When children and older people suffer trauma, the main causes are domestic accidents and childhood games (LI et al., 2015; CARVALHO FILHO et al., 2015).

Regarding etiology, a number of author point traffic accidents as the main cause of facial trauma (MANODH et al., 2016; MOURA, DALTRO, ALMEIDA, 2016; MARSICANO et al., 2019; SIKORA et al., 2020). Among traffic accidents, motorcycle accidents represented the main cause of facial trauma in our study, which is in agreement with other studies (MARTINS JUNIOR; KEIM; HELENA, 2010; JAN et al., 2015). This finding of our study is also explained by the importance the hospital in which the investigation was conducted, which is a reference in the treatment of traumatism in the north of Ceará. About this region, it's frequently observed that the drivers do not respect the transportation laws, which might result in an increased number of accidents.

Although we found traffic accidents as the main responsible for facial trauma, in other regions of Brazil this reality has changed due to the improvements in the safety tools of the vehicles, such as safety belts and airbags. Moreover, the laws are more rigorous in terms of speed limits, drinking, and driving. Thus, in such places, urban violence has become the main cause of facial trauma (MATOS et al., 2010; SKVIRSKY et al, 2017).

Thus, as other authors have suggested, we believe that the etiology of facial trauma is influenced by the period of the year, sociodemographic, cultural, and geographic factors, as well as by the use of alcohol and other drugs (MATOS et al., 2010).

As women are getting more space in society, they also are working more and spending more time outside, which makes them also drive more and, consequently, be more exposed to the risk of accidents, the main cause of facial trauma (MOURA, DALTRO, ALMEIDA, 2016). However, as we observed in our investigation, women are less affected by facial trauma than men, which is makes us assume that they drive more carefully (ANVISA, 2017; BONAVOLONTÀ et al., 2017).

Moreover, we also observed a higher prevalence of simple fractures of the mandibular and zygomatic bone. The same was found in other investigations (CAVALCANTE et al., 2012; BONAVOLONTÀ et al., 2017). Studies performed by Peeters et al. (2016) found that the nasal bone was the most affected by trauma. The authors explained their findings by saying that the nasal bone is more prominent and located at the center of the face, which makes it more prone to be fractured in accidents.

The complications of facial trauma can be permanent or reversible as they are depended on the treatment and type of lesion. Among the main consequences of facial trauma are ophthalmologic lesions, infection, scars, facial palsy, facial asymmetry, paresthesia, malocclusion and pain (MOTAMEDI, 2003; CERQUEIRA et al., 2010).

In our study, we observed a rate of $4.2 \%$ of infection cases after facial trauma, which is a prevalence similar to what the previously mentioned study found, and lower than the $15 \%$ reported in the literature (PEREIRA et al., 2011; ANVISA, 2017).

In cases of infection post facial trauma, cellulite is a common finding, thus there is not secretion, which allows the performance of the Antibiotic Susceptibility test (AST). Such an examination is important, mainly in cases of severe infections, when there is death risk; the patient is systemically compromised, when the patient is irresponsive to antibiotics, and when superinfection is suspected. Although the AST is of extremely value, it is not a routine test in hospitals. Thus, even in cases for which there is a clear indication of AST, antibiotic therapy is empirically established while the results of the tests are not available (REZAEI et al., 2017).

Haug and Assael (2002) have suggested a protocol of antibiotic therapy, administration pathways, and dosage according to the types of wounds after trauma. Such protocol is followed by the Santa Casa de Misericórdia de Sobral as a way to minimize the cases and spread of 
infections. That explains why we observed a low prevalence of nosocomial infection after the treatment of facial trauma.

Although we showed a well-defined epidemiological profile of facial trauma in the hospital in which this study was made, our investigation presents some limitations, such as the impossibility of identifying the etiology agent of trauma for some of the patients and of performing the AST for all the cases of nosocomial infection that we identified.

\section{CONCLUSION}

Our data demonstrated that the majority of the patients treated for facial trauma at the Santa Casa de Misericordia de Sobral were men aging from 20 to 39 years old who had suffered a simple fracture of the mandibular bone after a motorcycle accident. Therefore, these results suggest that the bucomaxillofacial surgeon has an important role in the emergency of a hospital and that the work of such professional might contribute to the understanding of the main causes of facial trauma.

\section{REFERENCES}

ALVES, L.S.; ARAGÃO, I.; SOUSA, M.J.C. et al. Pattern of Maxillofacial Fractures in Severe Multiple Trauma Patients: A 7-year Prospective Study. Br Dent J, v. 25, n. 6, p. 561-564, 2014.

ANVISA. Agência Nacional de Vigilância Sanitária Critérios Diagnósticos de Infecção Relacionada à Assistência à Saúde. $2^{\text {a }}$ Ed. Brasília, 2017.

BONAVOLONTÀ, P.; DELL'AVERSANA, O.G; ABBATE, V. et al. The epidemiological analisys of maxillofacial fractures in Italy: the experience of a single tertiary center with 1720 patients. J CranioMaxilloFac Surg, v. 45, n. 8, p.1319-1326, 2017.

CARVALHO FILHO, M.A.M; SAINTRAIN, M.V.L; ANJOS, R.E.S. et al. Prevalence of oral and maxillofacial trauma in elders admitted to a reference hospital in northeastern Brazil. Plos One, v.10, n.8, aug, 2015.

CAVALCANTE, J.R.; OKA, S.C.; DOURADO, E. et al. Influence of helmet use in facial trauma and moderate traumatic brain injury victims of motorcycle accidents. J Craniofac Surg, v. 23, n. 4, p. 982-985, 2012.

CERQUEIRA, A.; ANDRADE, M.G.S; LIMA, A.T.F.T et al. Prevalência de complicações oftalmológicas em portadores de fraturas do complexo zigomático. Rev. Cir. Traumatol. Buco-maxilo-fac, Camaragibe, v. 10, n. 3, p. 67-72, 2010.

HAUG, R.H; ASSAEL, L.A. Infection in Maxillofacial Trauma patient. In: Topazian RG, Goldenberg MH, Hupp JR. Oral and Maxillofacial Infections. 4Ş ed. Philadelphia: Saunders; p. 359-80, 2002.

JAN, A.M.A.; ALSEHAIMY, M.; AL-SEBAEI, M. et al. A retrospective study of the epidemiology of maxillofacial trauma in Jeddah, Saudi Arabia. J Am Sci., v. 11, n. 1, p. 57-61, 2015.

LI, R.; ZHANG, R.; LI, W.; PEI, F. et al. Analysis of 126 hospitalized elder maxillofacial trauma victims in central China. Med Oral Patol Oral Cir Bucal., v. 20, n. 4, p. 464470, 2015.
MANODH, P.; SHANKAR, D.P.; PRADEEP, D. et al. Incidence and patterns of maxillofacial trauma-a retrospective analysis of 3611 patients - an update. Oral Maxillofac Surg., v. 20, n. 4, p. 377- 383, 2016.

MARSICANO, J.A; CAVALLERI, N.Z; CORDEIRO, D.M et al. Epidemiology of maxillofacial trauma in a prehospital service in Brazil. Journal of trauma nursing, v.26, n.6, nov-dec, 2019.

MARTINS JUNIOR, J.C; KEIM, F.S.; HELENA, E.T.S. Epidemiological Characteristics of Trauma Patients Maxillofacial Surgery at the Hospital Geral de Blumenau SC from 2004 to 2009. Int Arch Otorhinolaryngol., v. 14, n.2, p.192-198, 2010.

MATOS, F.P.; ARNEZ, M.F.M.; SVERZUT, C.E. et al. A retrospective study of mandibular fracture in a 40-month period. Int J Oral Maxillofac Surg., v. 39, n.1, p. 10-15, 2010.

MOTAMEDI, M.H.K. An assessment of maxillofacial fractures: a 5-year study of 237 patients. J Oral Maxillofac Surg., v. 61, n.1, p. 61-64, 2003.

MOURA, M.T.F.L; DALTRO, R.M; ALMEIDA, T.F. Traumas faciais: uma revisão sistemática da literatura. RFO, v.21, n.3, p.331-337, set-dez, 2016.

PEREIRA, C.M.; SILVA FILHO, M.; CARNEIRO, D.S. et al. Epidemiology of maxillofacial injuries at a regional hospital in Goiania, Brazil, between 2008 and 2010. South Br Dent., v. 8, n. 4, p.381395, 2011.

PEETERS, N; LEMKENS, P; LEACH, R. et al. Facial trauma. B-ENT, v.12, suppl. 26/2, p.1-18, 2016.

REZAEI, M.; JAMSHIDI, S.; JALILIAN, T. et al. Epidemiology of maxillofacial trauma in a university hospital of Kermanshah, Iran. J Oral Maxillofac Surg Med Pathol, v. 29, n. 2, p. 110-115, 2017.

SIKORA, M.; CHLUBEK, M.; GROCHANS, E. et al. Analysis of factors affecting quality of life in patients treated for maxillofacial fractures. Int. J. Environ. Res. Public Health, v.17, n.4, 2020.

SKVIRSKY, V.; BEN-ARI, O.T; GREENBURY, T.J. et al. Contributors to Young driver's driving styles- A comparison between Israeland Queensland. Accident Analysis and Prevention, v.109, p. 47-54, 2017.

\section{ACKNOWLEDGMENT}

This work was partly supported by Santa Casa de Misericórdia, Sobral, Ceará, Brazil (Edital DEPE 02/2018).

\section{COPYRIGHT}

Copyright: the authors are solely responsible for the material included in the paper.

Submetido em: 08/09/2020 Aprovado em: 15/10/2020 


\section{Área: Ciências Exatas e Engenharias}

\begin{tabular}{|c|c|}
\hline $1-3$ & $\begin{array}{l}\text { UM MODELO DE INFRAESTRUTURA DE MICROSSERVIÇOS PARA } \\
\text { ALGORITMOS DE AGRUPAMENTO DE FLUXOS CONTÍNUOS DE DADOS } \\
\text { A MICROSERVICE INFRASTRUCTURE MODEL FOR STREAMING DATA } \\
\text { CLUSTERING ALGORITHMS } \\
\text { Giuliano Oliveira De Macedo; Jonathan Andrade Silva; Dionisio Machado Leite Filho }\end{array}$ \\
\hline $1-6$ & $\begin{array}{l}\text { DESENVOLVIMENTO DE ATIVIDADE EXPERIMENTAL UTILIZANDO } \\
\text { INDICADOR ÁCIDO-BASE EXTRAÍDO DE FLORES DA PAISAGEM COTIDIANA } \\
\text { DEVELOPMENT OF EXPERIMENTAL ACTIVITY USING ACID-BASE INDICATOR } \\
\text { EXTRACTED FROM DAILY LANDSCAPE FLOWERS } \\
\text { Carlos Da Silva Lopes; Maria De Fátima Vaz Xavier; Lara Oliveira Paiva Ribeiro; } \\
\text { Karen De Vasconcelos Feitosa }\end{array}$ \\
\hline $3-4$ & $\begin{array}{l}\text { GERAÇÃO COMPARTILHADA DE ENERGIA ELÉTRICA ATRAVÉS DE } \\
\text { CONSÓRCIOS E COOPERATIVAS } \\
\text { SHARED GENERATION OF ELECTRICITY THROUGH CONSORTIUMS AND } \\
\text { COOPERATIVES } \\
\text { Allana De Moura Netto; Jair Urbanetz Junior; Américo Vicente Teixeira Leite }\end{array}$ \\
\hline $3-5$ & $\begin{array}{l}\text { MODELAGEM E SIMULAÇÃO DE UM BANCO DE ESTOCAGEM EM BATERIAS } \\
\text { COM GERADOR FOTOVOLTAICO } \\
\text { MODELING AND SIMULATION OF A STOCK BANK IN BATTERIES WITH } \\
\text { PHOTOVOLTAIC GENERATOR } \\
\text { Márcio Augusto Teles Da Cruz; João Batista Dias }\end{array}$ \\
\hline $3-5$ & $\begin{array}{l}\text { MODELAGEM, SIMULAÇÃO E IMPLANTAÇÃO DE SISTEMA FOTOVOLTAICO } \\
\text { PARA ALIMENTAÇÃO DE DISPOSITIVO DE MONITORAMENTO REMOTO DE } \\
\text { DRENAGEM ELÉTRICA } \\
\text { MODELING, SIMULATION AND IMPLEMENTATION OF A PHOTOVOLTAIC } \\
\text { SYSTEM FOR POWERING REMOTE MONITORING DEVICE OF ELECTRIC } \\
\text { DRAINAGE } \\
\text { Márcio Augusto Teles Da Cruz; João Batista Dias }\end{array}$ \\
\hline $3-8$ & $\begin{array}{l}\text { DESENVOLVIMENTO DE FERRAMENTA PARA OTIMIZAÇÃO DO MÉTODO DE } \\
\text { REDUÇÃO DE RISCOS CONTRATUAIS EM EMPREITADAS NA CONSTRUÇÃO } \\
\text { CIVIL } \\
\text { DEVELOPMENT OF TOOL FOR OPTIMIZING THE METHOD OF REDUCING } \\
\text { CONTRACTUAL RISKS IN CIVIL CONSTRUCTION CONTRACTORS } \\
\text { Mônica Miranda De Carvalho; Ana Regina Santos De Camargo; Adriana De Paula } \\
\text { Lacerda Santos }\end{array}$ \\
\hline $3-8$ & $\begin{array}{l}\text { OTIMIZAÇÃO DE FROTA DE EMPILHADEIRA: UM ESTUDO DE CASO } \\
\text { FORKLIFT FLEET OPTIMIZATION: A CASE STUDY } \\
\text { Mariana Og Gallo Esteves; Nilo Antonio De Souza Sampaio; José Glênio Medeiros } \\
\text { De Barros; Antonio Henriques De Araujo Junior }\end{array}$ \\
\hline
\end{tabular}




\begin{tabular}{|c|c|}
\hline 3-8 & $\begin{array}{l}\text { REDUÇÃO DE PERDAS ATRAVÉS DA DIGITALIZAÇÃO DE PROCESSOS NO } \\
\text { CONTEXTO DA INDÚSTRIA } 4.0 \\
\text { WASTE REDUCTION THROUGH DIGITALIZATION OF PROCESSES IN THE } \\
\text { CONTEXT OF INDUSTRY } 4.0 \\
\text { Marcos Ronaldo Albertin; Jusicleiton Santos Pereira; Heráclito Lopes Jaguaribe } \\
\text { Pontes }\end{array}$ \\
\hline 3-8 & $\begin{array}{l}\text { AVALIAÇÃO DE INDICADORES EMPRESARIAIS ATRAVÉS DA ANÁLISE } \\
\text { FATORIAL EXPLOTARÓRIA E TEORIA DE RESPOSTA AO ITEM } \\
\text { EVALUATION OF BUSINESS INDICATORS USING EXPLORATORY FACTOR } \\
\text { ANALYSIS AND ITEM RESPONSE THEORY } \\
\text { Marcos Ronaldo Albertin; Marcos Charles Pinheiro Baltazar; Heráclito Lopes } \\
\text { Jaguaribe Pontes }\end{array}$ \\
\hline
\end{tabular}




\title{
Revista SODEBRAS - Volume 15 \\ $\mathrm{N}^{\circ} 178$ - OUTUBRO/ 2020
}

\section{UM MODELO DE INFRAESTRUTURA DE MICROSSERVIÇOS PARA ALGORITMOS DE AGRUPAMENTO DE FLUXOS CONTÍNUOS DE DADOS}

\author{
A MICROSERVICE INFRASTRUCTURE MODEL FOR STREAMING DATA \\ CLUSTERING ALGORITHMS
}

\author{
GIULIANO OLIVEIRA DE MACEDO ${ }^{1}$; JONATHAN ANDRADE SILVA ${ }^{1}$; \\ DIONISIO MACHADO LEITE FILHO ${ }^{1}$ \\ 1 - UNIVERSIDADE FEDERAL DO MATO GROSSO DO SUL (UFMS)- CAMPUS DE PONTA PORÃ \\ \{giuliano.llpinokio,jonathannos\}@gmail.com,dionisio.leite@ufms.br
}

\begin{abstract}
Resumo - Algoritmos de agrupamento de fluxo contínuo são extremamente úteis na definição de padrões e definição de objetos, no entanto, esses algoritmos são caros computacionalmente, necessitando de uma infraestrutura computacional robusta. Considerando o problema de ausência de recursos, este trabalho propõe um ambiente escalável utilizando microsserviços para sanar o problema de ausência de recursos computacionais. A metodologia utilizada aplica o conceito de balanceador de carga entre os nós presentes visando a escalabilidade da solução. A essa estrutura foi aplicado um algoritmo de agrupamento de dados de fluxo contínuo promovendo o desenvolvimento de um sistema escalável. A natureza escalável dos microsserviços possibilitou adicionar ou remover nós de processamento sem a necessidade de reconfiguração de código e reconfiguração de infraestrutura, aumentando, assim, a transparência do sistema em relação aos recursos físicos disponíveis. Os resultados foram satisfatórios em relação aos agrupamentos alcançados, sendo a validação do modelo, uma das principais contribuições deste trabalho.
\end{abstract}

Keywords: Microsserviços. Agrupamento de Streaming. Escalabilidade.

Abstract - Streaming clustering algorithms are extremely useful in defining patterns and defining objects. However, these algorithms are computationally expensive, requiring a robust computational infrastructure. Considering the problem of lack of resources, this work proposes a scalable environment using microservices to solve the problem of a lack of computational resources. The concept of load balancer between the nodes present to scale the solution was applied as the methodology. A streaming clustering algorithm was applied to this structure, promoting the development of a scalable system. The scalable nature of microservices made it possible to add or remove processing nodes without the need for code reconfiguration and infrastructure reconfiguration, thus increasing the system's transparency about the available physical resources.

Keywords: Microservice. Streaming Clustering. Scalability.

\section{INTRODUÇÃO}

Os avanços recentes em hardware e software têm proporcionado a aquisição de dados em grande escala. Esses dados podem ser gerados continuamente, em ambientes dinâmicos e em grandes taxas contrariamente ao que acontece com as bases de dados tradicionais. Fontes que geram dados nessa escala são chamadas de fluxos contínuos de dados (GUHA et al. 2000) (GAUTAN e BASAVA, 2019).
O agrupamento desses dados, feito sob demanda, propicia informações resumidas dos mesmos, dando ao administrador do sistema poder de decisão através do sistema. Alguns exemplos de aplicação para essa técnica podem ser: diferenciar usuários maliciosos de usuários comuns num servidor Web (AGGARWAL et al. 2003); categorizar pesquisas de usuários num site de pesquisa online (LI et al. 2003); classificar utilidade de um gene (REGEV et al. 2012).

Há diversos algoritmos para realizarem agrupamento de dados, um deles o BIRCH (ZHANG et al. 1996) oferece alta qualidade de agrupamento, porém o armazenamento dos dados gerados não é eficaz. Esse é um problema não só do BIRCH, como de outros algoritmos de agrupamento, pela alta necessidade de um sistema robusto para a manipulação dos dados.

Uma possível maneira de mitigar esse problema é utilizar microsserviços em vez de métodos tradicionais de desenvolvimento. O desenvolvimento de aplicações pode ser feito de várias formas, como aponta Medeiros et al. (2019). Uma delas é aplicar uma arquitetura de microsserviços, que utiliza o conceito de serviços e permite que um serviço seja "escalado" de forma horizontal ou vertical (Zhang et al. 2019). Dessa forma, a arquitetura de microsserviços é voltada para a criação de aplicações altamente escaláveis.

A diferença entre uma aplicação com microsserviço de uma aplicação tradicional é a possibilidade de decomposição de uma aplicação em funções menores. Cada função é denominada serviço e pode ser criada e implantada de maneira independente. Isso significa que cada serviço individual pode funcionar ou falhar sem comprometer os demais (SAMPAIO et al. 2019).

Considerando o problema de ausência de recursos para algoritmos de agrupamento de dados contínuos e as possibilidades que a arquitetura de microsserviço pode propiciar, este trabalho propõe a construção de um modelo escalável para a execução de algoritmos de agrupamento de dados.

Essa escalabilidade visa aumentar os recursos computacionais necessitados pela execução do algoritmo sem a necessidade de reformulação de código. Assim, esse trabalho contribui para a área de agrupamento de dados com o modelo de serviços para algoritmos de agrupamento de dados; e propõe uma metodologia para definição de um 
ambiente de microsserviço que pode ser estendida a outros problemas envolvendo escalabilidade de aplicação.

\section{TRABALHOS RELACIONADOS}

Os fluxos de dados são muito úteis em sistemas como transmissão de dados, comércio eletrônico e sistemas de detecção de intrusão. Um volume maciço de informações é necessário para executar a tomada de decisão. Para realizar essa tarefa, muitos recursos computacionais são necessários (BUSTIO-MARTINEZ et al. 2019).

Grandes volumes de dados dificultam a criação de ferramentas, tecnologias, métodos e técnicas de mineração de dados devido à aquisição dinâmica de dados (KOLAJO et al. 2019). Para os autores, os problemas ainda em aberto nos fluxos de dados são escalabilidade, privacidade e balanceamento de carga (KOLAJO et al. 2019).

Isah e Zulkernine (2018) apresentam uma proposta de estrutura escalável para trabalhar com fluxo de dados. O grau desejado de escalabilidade e robustez no tratamento de falhas foi explorado por (ISAH and ZULKERNINE 2018). Como resultado, os autores apresentam a necessidade de um sistema de ingestão de fluxo de dados ser escalável, robusto e extensível, suportando fluxo de dados entre muitos produtores e consumidores independentes (ISAH and ZULKERNINE 2018).

O processamento de fluxo de dados levou a pesquisas sobre o uso de arquiteturas multicore, o uso de janelas para extração de conhecimento e a otimização do uso de memória. Essas preocupações são importantes devido à natureza da geração de dados, que tende a ter grandes volumes de dados. A paralelização desse processamento foi desenvolvida, principalmente, usando MapReduce. O Mapreduce fornece tolerância a falhas e escalabilidade. Essa escalabilidade é obtida com algumas modificações, dependendo do número variável de nós envolvidos no processamento de fluxos de dados. Tserpes (2019) traz uma metodologia que pode beneficiar a criação de pipelines curtos, rápidos e de processamento de fluxos usando microsserviços. A proposta de arquitetura de microsserviço de fluxo (stream-MSA) foi desenvolvida visando poder oferecer soluções robustas e de baixo custo.

Nesse sentido, este artigo apresenta uma abordagem baseada em microsserviços que pode ser usada para mitigar problemas de alocação de memória, alta volume de processamento e escalabilidade com o desenvolvimento de uma estrutura bem definida usando microsserviços.

\section{MÉTODOS}

A infraestrutura desenvolvida neste trabalho é definida, em um primeiro momento, como: nó mestre, e um ou mais nós executores. A definição da arquitetura para os nós executores prevê a definição de um ambiente onde pode haver apenas rede local, haver apenas rede remota ou um modelo híbrido. A Figura 1 apresenta o modelo desenvolvido.
Figura 1 - Ambiente genérico para a definição da infraestrutura

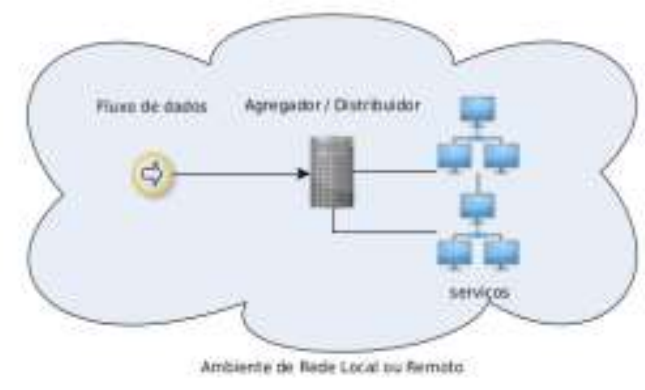

Fonte: Autores

Considerando a Figura 1, nota-se que a metodologia abordada neste trabalho propicia o desenvolvimento de uma solução que pode ser usada em uma rede local, mas também pode ser utilizada de forma remota, como na nuvem, por exemplo. Esse desenvolvimento só é possível pela utilização do Docker, que também é utilizado pelos provedores de nuvem.

A infraestrutura funciona da seguinte maneira, primeiramente o nó mestre recebe qualquer quantidade de pontos $K$ de $N$ dimensões de qualquer fonte possível. Esses pontos podem ser informações de sensores, sites, banco de dados.

De posse desses dados, o nó mestre cria lotes com uma quantia de pontos e replica a todos os seus nós escravos, essa quantia é chamada de batch(n), e também define um coeficiente de $\mathrm{K}$-grupos $(K F C)$ para que os nós possam criar um conjunto de Ks automaticamente balanceados baseados no número total atual de nós $(K L)$, desta forma, com o $N$ sendo o número de pontos recebidos num instante, o conjunto de $\kappa(K F, K L, n)$ é definido da seguinte maneira:

$k(K F, K L, n)=\{K \in(N-\{0,1\}), x \in N|K=K F+x K L \Lambda 0 \leq x \leq| \sqrt{ } n \mid$

Dessa forma, considerando a Equação 1, cada nó tem um conjunto de $K$ sem sobreposições e de tamanhos similares, para que haja um balanceador de carga efetivo.

Após essa fase, os escravos irão agrupar os pontos recebidos até o momento com todos os Ks do conjunto N(i) paralelamente, e enviar ao servidor uma tripla com o $\mathrm{K}$, índice de lote e silhueta do agrupamento.

Nesse ponto, também paralelamente, o servidor cria Buckets com vetores de tamanho $\left|\bigvee_{n}\right|$ onde cada entrada desse vetor é um K que algum dos escravos irá agrupar, e também a silhueta do mesmo.

O servidor irá calcular a silhueta máxima de todos os Ks recebidos assim que o vetor estiver cheio, sendo assim, ele irá ter o melhor $\mathrm{K}$ para aquele índice de lote e poderá a qualquer momento requisitar a qualquer escravo os rótulos para o agrupamento com aquele $\mathrm{K}$. Com isso temos a definição da infraestrutura escalável para a execução dos fluxos.

\section{RESULTADOS}

Como resultados são apresentados os modelos de infraestrutura a serem adotados e os algoritmos para que a infraestrutura funcione de forma escalável. Na Figura 2 são apresentados os fluxos que podem ser considerados ao se utilizar o modelo proposto. 
Figura 2 - Fluxo de operação do modelo proposto considerando ambiente local e remoto

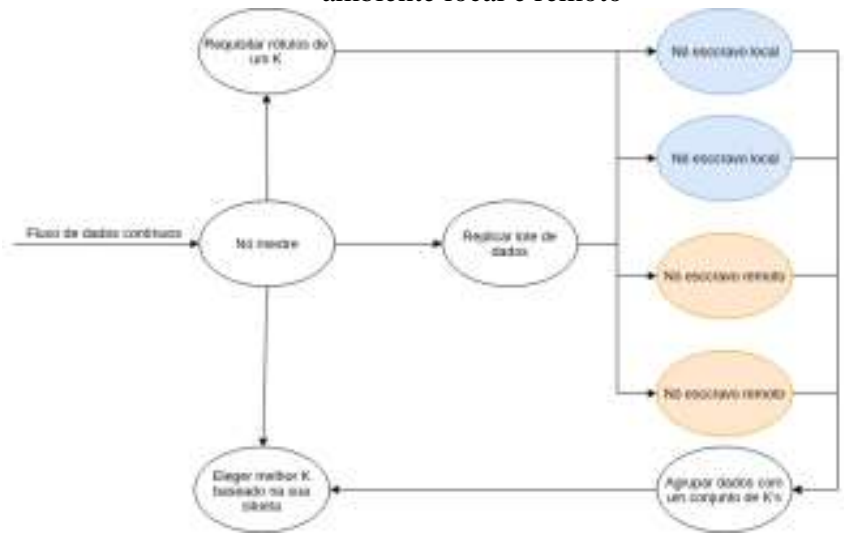

Fonte: Autores.

Na Figura 2 são apresentados os fluxos adotados pelo modelo proposto para a criação e distribuição dos lotes de processamento. Há replicações necessárias para manter a integridade e consistência das informações dos fluxos. Esse fato é necessário uma vez que a informação de um nó pode ser dependente em outro nó de execução.

Além disso, é possível operar tanto de maneira local, como de maneira remota ou hibrida o modelo proposto, isso faz com que esse modelo seja escalável, de acordo com os recursos disponibilizados.

O algoritmo de escalonamento, que executa no nó mestre, é essencial para o balanceamento de carga e a correta distribuição dos lotes de execução para os nós escravos. Este algoritmo é descrito como:

\section{Algoritmo de escalonamento do nó mestre \\ 1: slaves Set(socket); //Lista de nós conectados \\ 2: source Generator(DataPoint); //dataset origem \\ 3: responses List(integer); // contém cada silhueta para cada \\ $\mathrm{K}$ com índice de lote \\ 4: bucket Bucket(); //contém cada tempo, silhueta e \\ conexão para cada indice \\ 5: batch_size integer; //tamanho dos pedaços que o dataset} será dividido

6: KF integer; // KF é definido no conjunto $\kappa$

7: KL integer; //KL é definido no conjunto $\kappa$

STEP 1: //inicializa cada escravo com seus parâmetros KF e

KL

8: KL Łslaves.size();

9: $\mathrm{KF} \leftarrow 2$;

10: for each slave $\in$ slaves do

11: $\quad$ slave.send(KF);

12: $\quad$ slave.send(KL);

13: $\mathrm{KF}++$;

14: end for

STEP 2: //comprimi e replica cada lote para todos os escravos em paralelo

15: for each batch $\in$ source.batches(bath size) do in parallel

16: $\quad$ batch $\leftarrow$ deflate compress(batch);

17: for each slave $\in$ slaves do in parallel

18: $\quad$ slave.send(batch);

19: $\quad$ end for

20: end for

STEP 3: //recebe cada resposta dos escravos e calcule qual é o melhor k para cada índice de lote em paralelo
21: silhouette integer; //silhueta do escravo atual 22: batch_index integer; //índice do lote atual

23: $\mathrm{k}$ integer; // $\mathrm{k}$ do escravo atual

24: for each slave $\in$ slaves do in parallel

25: $\quad$ silhouette $\leftarrow$ slave. $\operatorname{recv}()$;

26: $\quad \mathrm{k} \leftarrow$ slave.recv();

27: $\quad$ batch index $\leftarrow$ slave.recv();

28: bucket.in(batch index).add(k,silhouette)

29: if bucket.in(batch_index) is full then

30: $\quad$ responses.add(encontre $\mathrm{k}$ com a maior

silhueta e com batch index no bucket)

31: $\quad$ end if

32: end for

STEP 4: //solicita etiquetas para o melhor $\mathrm{K}$ de cada vez

33: labels List(integer); //dados preditos

34: winner slave Socket; //escravo que tem o melhor k para

$\mathrm{t}$

35: for each response $\in$ responses do

36: $\quad$ winner slave $\leftarrow$ slaves.find(slave with

$\mathrm{k}=$ response.k);

37: $\quad$ winner slave.send(response.k);

38: winner slave.send(response.t);

39: labels.append(winner slave.recv());

40: end for

O nó mestre será responsável por controlar a quantidade de nós conectados e fazer a separação de lotes de forma justa entre esses nós. Para cada lote será definido um K, de acordo com o propósito de classificação do sistema, e os nós escravos ficaram com a responsabilidade de executar essas classificações.

Um modelo de classificação simples foi utilizado como serviço, dessa forma, o escravo possui apenas um classificador para determinar a classificação para os Ks que lhe forem passados. Esse procedimento foi realizado para validar a operação do modelo e verificar a possibilidade de utilização de microsserviços para garantir escalabilidade ao ambiente de classificação de fluxo de dados.

Para verificar a viabilidade do modelo de infraestrutura proposto, alguns experimentos foram realizados. A configuração dos nós utilizados é apresentada na Tabela 1.

Tabela 1- Configurações utilizadas

\begin{tabular}{ll}
\hline Descrição & Sistema \\
\hline SO & Ubuntu 18.04 X64 \\
\hline Processador & i7-6700 CPU 3.4GHz X 8 \\
\hline Memória & $16 \mathrm{~GB}$ \\
\hline Quantidade nós & 4 \\
\hline Programa/Sistema & Versão \\
\hline Python & 3.7 .3 \\
\hline Docker Cli & 4.0 .2 \\
\hline Scipy & 1.1 .0 \\
\hline Pandas & 0.25 .1 \\
\hline Numpy & 1.15 .0 \\
\hline & Fonte: Autores.
\end{tabular}

Os resultados alcançados são apresentados a seguir. Os resultados são expressos em tempo de execução e silhueta alcançada. Para o propósito deste trabalho, considerou-se 
como exitoso todo resultado que possuía um valor de $\mathrm{K}$ esperado. As Figuras 3 e 4 apresentam os resultados.

Figura 3 - Desempenho na validação da infraestrutura

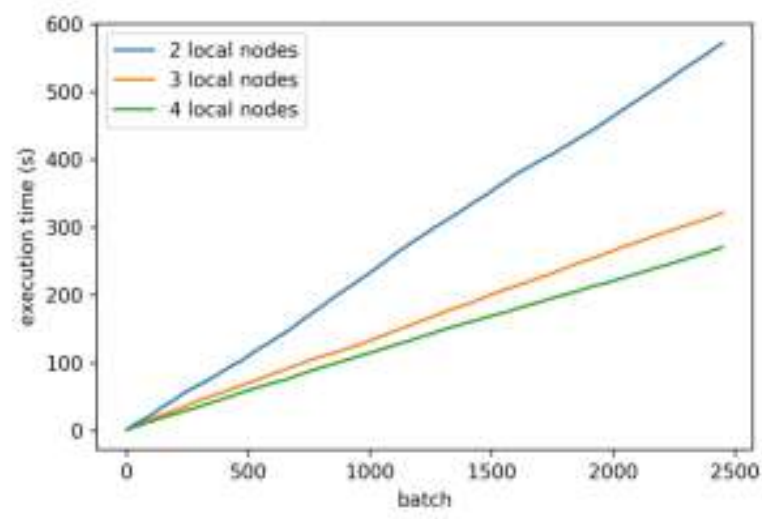

Fonte: Autores.

Figura 4 - Silhuetas alcançadas

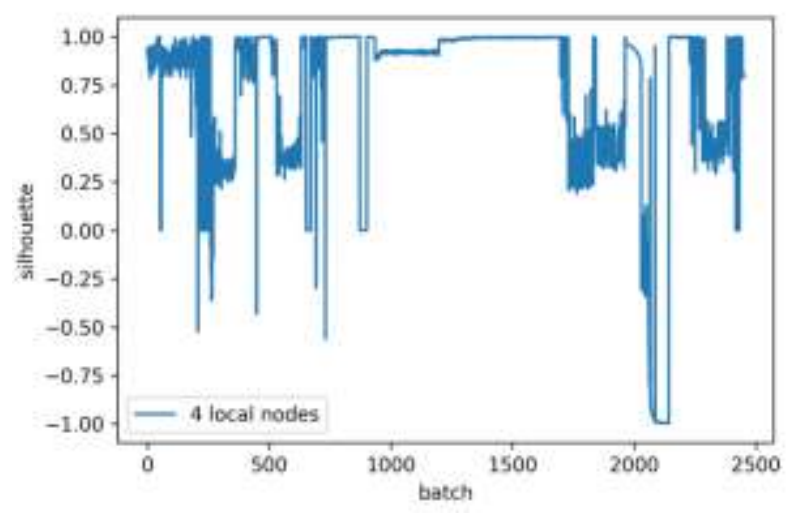

Fonte: Autores.

Para os resultados em tempo de execução, Figura 3, nota-se que o comportamento foi o esperado para o aumento de nós. Na execução dos experimentos, o agrupamento foi exitoso tanto com a redução de nós como para o aumento de nós.

Não foram exploradas características de tolerância a falhas, uma vez que havendo batches sem respostas, os mesmos eram reenviados para outros nós escravos.

Para os resultados de silhueta, Figura 4, se os resultados alcançam índice 1, a qualidade do agrupamento é tida como ótima. Para os resultados em 0 , pode se afirmar que os resultados tendem a ser equilibrados e necessitam de revisão, uma vez que não se pode afirmar que resultados são satisfatórios. Quando os resultados tendem a resultados negativos os resultados são tidos como ruins.

A silhueta é calculada por objeto, nesse caso, os resultados apresentados são valores médios das silhuetas de cada objeto para o conjunto dados experimentados ou batches. Casos de falhas em nós não foram considerados.

\section{DISCUSSÃO}

Um ponto de interesse nesta proposta de infraestrutura é a possibilidade de uso de recursos remotos. Os principais recursos remotos podem ser definidos como os disponibilizados em nuvem.
Um ponto de destaque para a solução local e remota são os custos com a nuvem, na abordagem proposta foi definido que enquanto houver recursos locais, os mesmos serão utilizados. No momento que os recursos locais não forem mais suficientes, a nuvem pode ser ativada. Esse mecanismo prevê uma economia se for considerada apenas a execução dos nós escravos em nuvem.

Uma das melhorias propostas por esse modelo é a escalabilidade da aplicação, nesse caso, o fator de escalabilidade é muito maior para os nós remotos dos que os locais, sendo que para aumentar ou diminuir o número de escravos remotos locais é apenas uma questão de algumas requisições ao servidor que controla o sistema de microsserviços.

Por se tratar de um modelo de infraestrutura, vários pontos ainda necessitam ser explorados, como a tolerância a falhas e o uso da infraestrutura para proceder não só com o agrupamento, mas também com a classificação dos dados.

\section{CONCLUSÃO}

Escalabilidade de aplicações pode ser o fator decisivo para o sucesso ou fracasso de uma aplicação. Neste trabalho foi explorada a escalabilidade para a execução de algoritmos de agrupamento de dados.

A escalabilidade, na proposta deste trabalho, visou aumentar os recursos computacionais necessitados pela execução do algoritmo de agrupamento de dados sem a necessidade de reformulação de código. Para essa ação, o presente trabalho obteve êxito, contribuindo para o desenvolvimento de uma metodologia de distribuição de carga entre os nós escravos.

A principal contribuição alcançada é relacionada à área de agrupamento de dados com o modelo de serviços para algoritmos de agrupamento de dados. Na literatura, há um esforço para o desenvolvimento de infraestrutura escalável com o uso de microsserviços de maneira teórica, ou seja, como seria o desenvolvimento da solução. Para o presente trabalho, há o desenvolvimento de fato de um modelo de infraestrutura funcional.

As limitações do trabalho podem ser numeradas como: tolerância a falhas entre nós escravos e mestre, utilização da infraestrutura para algoritmos de classificação, utilização da infraestrutura em ambientes de Machine learning e deep learning. Essas limitações serão exploradas como trabalhos futuros, uma vez que abrangem várias áreas de conhecimento.

\section{AGRADECIMENTOS}

O presente trabalho foi realizado com apoio da Fundação Universidade Federal de Mato Grosso do Sul - UFMS/MEC - Brasil.

\section{REFERÊNCIAS}

AGGARWAL, C. C., HAN, J., WANG, J., and YU, P. S. A framework for clusteringevolving data streams. In. Proceedings of the 29th International Conference on VeryLarge Data Bases, v.29, VLDB '03, p. 81-92. VLDB Endowment, 2003.

BUSTIO-MARTINEZ, L., MUÑOZ-BRISEÑO, A., CUMPLIDO, R., HERNANDEZ-LEON, R., e FEREGRINO-URIBE, C. A novel multi-core algorithm for frequent itemsets mi-ning in data streams. Pattern Recognition Letters, 125:241 - 248, 2019. 
GAUTAM, B. and BASAVA, A. Performance prediction of data streams on high-performance architecture. Humancentric Computing and Information Sciences, 9(1):1-2, 2019.

GUHA, S., MISHRA, N., MOTWANI, R., and O'CALLAGHAN, L. Clustering data streams. In Proceedings 41st Annual Symposium on Foundations of Computer Science, p.359-366, 2000.

ISAH, H. and ZULKERNINE, F. H. A scalable and robust framework for data streamingestion. CoRR, abs/1812.04197, 2018.

KOLAJO, T., DARAMOLA, O. and ADEBIYI, A. Big data stream analysis: a systematicliterature review. Journal of Big Data, 6(1):47, 2019.

LI, Y., ZHENG, Z., and DAI, H. K. Kdd cup-2005 report: Facing a great challenge. ACM SIGKDD Explorations Newsletter, 7(2):91-99, 2005.

MEDEIROS, D., FERRARI DE SÁ, R., and CANCIGLIERI Jr, O. Análise dos impactos causados em relação ao custo benefício e meio ambiente no desenvolvimento de produtos pelos métodos convencional e biomimético. Revista Sodebras [on line], v.14, n.164, Ago./2019, p.38-45, ISSN. 1809-3957. DOI: https://doi.org/10.29367/issn.18093957.14.2019.164.38.

REGEV, Y., FINKELSTEIN-LANDAU, M., FELDMAN, R., et al. Rule-based extrac-tion of experimental evidence in the biomedical domain: the kdd cup 2002 (task 1). 4(2):9092, 2002.

SAMPAIO, A. R., RUBIN, J., BESCHASTNIKH, I., and ROSA, N. S. Improvingmicroservice-based applications with runtime placement adaptation. Journal of Internet Services and Applications, 10(1):4, 2019.

TSERPES, K. Stream-msa: A microservices' methodology for the creation of short,fast-paced, stream processing pipelines. ICT Express, v.5, n.2, p.146 - 149, 2019.

ZHANG, F., TANG, X., LI, X., KHAN, S. U. and LI, Z. Quantifying cloud elasticitywith container-based autoscaling. Future Generation Computer Systems, 98:672-681, 2019.

ZHANG, T., RAMAKRISHNAN, R., and LIVNY, M. Birch: an efficient data clusteringmethod for very large databases. In. ACM Sigmod Record, v. 25, p.103-114. ACM, 1996.

\section{COPYRIGHT}

Direitos autorais: Os autores são os únicos responsáveis pelo material incluído no artigo.

Submetido em: 14/09/2020

Aprovado em: 05/10/2020 


\title{
Revista SODEBRAS - Volume 15 \\ $\mathrm{N}^{\circ} 178$ - OUTUBRO/ 2020
}

\section{DESENVOLVIMENTO DE ATIVIDADE EXPERIMENTAL UTILIZANDO INDICADOR ÁCIDO-BASE EXTRAÍDO DE FLORES DA PAISAGEM COTIDIANA}

\author{
DEVELOPMENT OF EXPERIMENTAL ACTIVITY USING ACID-BASE \\ INDICATOR EXTRACTED FROM DAILY LANDSCAPE FLOWERS
}

\author{
CARLOS DA SILVA LOPES ${ }^{1}$ MARIA DE FÁTIMA VAZ XAVIER ${ }^{2}$; \\ LARA OLIVEIRA PAIVA RIBEIRO ${ }^{3}$; KAREN DE VASCONCELOS FEITOSA ${ }^{4}$ \\ 1;2;3;4 - COLÉGIO PEDRO II, CAMPUS TIJUCA II \\ lopescsilva1966@gmail.com; vazfatima@ig.com.br; lara.opr@hotmail.com; kaia.feitosa@gmail.com
}

\begin{abstract}
Resumo - O uso de atividades experimentais no processo ensinoaprendizagem das Ciências pode ser uma estratégia importante, pois têm um papel motivador, ajuda a entender aspectos microscópicos e estimula o aluno a correlacionar o seu cotidiano com as teorias estudadas. Este trabalho foi desenvolvido por alunos do Ensino Médio do Colégio Pedro II do Campus Tijuca II e propõe uma atividade experimental que utiliza extratos de flores do cotidiano urbano como indicador ácido-base. Diversos vegetais podem cumprir a função de indicador ácido-base, para isso devem possuir uma classe de compostos chamada de Antocianinas. As flores utilizadas foram a Ixora chinensis e a Hibiscus rosa - sinensis. Os extratos aquosos e hidroalcoólicos foram eficientes quanto a sua utilização como indicador visto que puderam diferenciar, através da mudança de cor, compostos de caráter ácido/base.
\end{abstract}

Palavras-chave: Ensino. Experimentação. Aprendizagem.

Abstract - The use of experimental activities in the teachinglearning process of Sciences can be an important strategy, as they have a motivating role, help to understand microscopic aspects and encourage the student to correlate their daily life with the theories studied. It becomes more significant if the practices used have a sustainable bias. The activity was carried out by the students and in relation to its execution it was investigative. This work was developed by high school students from Colégio Pedro II of Campus Tijuca II and proposes an experimental activity that uses extracts of flowers from urban life as an acid-base indicator. Several vegetables can fulfill the function of acid-base indicator, for that they must have a class of compounds called Anthocyanins, substances that give the purplepink hue in flowers, fruits and plants. Anthocyanins are very delicate water-soluble pigments that can be transformed by the action of light, heat, microorganisms and variations in $\mathrm{pH}$ conditions. The flowers used were Ixora chinensis and Hibiscus rosa - sinensis. The aqueous and hydroalcoholic extracts were efficient in their use as an indicator since they could differentiate, through the color change, compounds of acid / base character.

Keywords: Teaching, Experimentation and Learning.

\section{INTRODUÇÃO}

A química por ser uma ciência abstrata impõe dificuldades ao processo de aprendizagem de seus conteúdos programáticos pelos alunos. Os professores, na tentativa de tornar o ensino mais atrativo, podem utilizar metodologias não convencionais que favoreçam o aprendizado e tornem a química mais significativa. Estimular os alunos a correlacionar o seu cotidiano com o estudado em sala de aula, minimiza a sua ação passiva e torna a aprendizagem mais prazerosa. É importante salientar que o processo de aprendizagem precisa de tempo, é um processo cumulativo e que envolve também, aspectos emocionais, sociais e físicos.

Uma das estratégias utilizadas por professores de ciências é a utilização de atividades experimentais, pois ajudam o discente a refletir sobre a ciência e entender que ela pode ser um facilitador no entendimento de conteúdos programáticos e de fenômenos do seu cotidiano.

As atividades experimentais possuem um papel motivador no ensino de ciências, além de aproximar o conteúdo formal da prática cotidiana. A experimentação pode ajudar o estudante a transformar o seu conhecimento em algo mais fundamentado, ou seja, mais do que um processo de valorização do conhecimento ela pode ser considerada uma forma de aprimoramento do aprendizado, ajudando o aluno a pensar o seu cotidiano de uma forma mais elaborada.

Segundo Izquierdo et al. (1999, p. 45), a experimentação na escola pode ter várias funções como a de exemplificação de um assunto, elaboração de atividades práticas, testar hipóteses ou como investigação. Para os autores, o processo investigativo é o que mais ajuda o aluno aaprender.

Guimarães (2009) relata que a utilização de experimentos motiva os alunos, facilitando a aquisição do conhecimento. A experimentação é vista como uma estratégia eficaz de aprendizado, pois através de problemas reais e concretos permite a contextualização e estimula a investigação. Porém, a observação num ambiente escolar não deve ser desvinculada da teoria.

De acordo com Giordan (1999) o caráter particular da experiência é um elemento importante para a assimilação do conhecimento universal. $\mathrm{O}$ contato com o fenômeno empírico ajuda na formulação de explicações dos fatos. Analisando a história da ciência, destaca-se o pensamento de Aristóteles, que propôs entender os fenômenos mesmo com a inexistência de instrumentos de medição, utilizando a 
observação como mediador entre sujeito e fenômeno. A compreensão da natureza era baseada em lógica.

A experimentação se consolidou, as situações empíricas passaram a fundamentar os elementos formulados. Os cientistas a partir da observação de um problema formulam hipóteses, efetuam experimentos, coletam dados, e divulgam seus resultados para a comunidade científica.

Segundo Andrade \& Massabni (2011), a atividade experimental deve ser contextualizada e favorecer o raciocínio e a criação. Ela é um elo entre o que se deseja ensinar e o cotidiano do aluno. Quando isto não ocorre, é comum observar certa indiferença do aluno o que dificulta atingir o objetivo de facilitar a compreensão de fenômenos naturais.

A experimentação sempre foi vista como uma estratégia para articular a teoria com a prática, motivando os alunos e permitindo consolidar o conhecimento químico, auxiliando na compreensão de fatos do dia a dia. A experimentação tradicional segue um roteiro e é utilizada para ilustrar teorias, porém as Diretrizes Curriculares mencionam que o contato do aluno com o objeto estudado é que permite a apropriação do conhecimento. A atividade experimental envolve o aluno e se torna uma agente facilitadora da aprendizagem, fazendo com que o aluno reflita a respeito dos conhecimentos e dialogue com o professor (GUIMARÃES, 2009; FERNANDES et al., 2017).

O desenvolvimento de atividades experimentais apresenta algumas características em comum com o uso de atividades lúdicas, pois pode ser motivadora para os estudantes, de acordo com a mediação do professor; torna-se divertida por apresentar uma proposta diferenciada da aula expositiva e tradicional e simula situações reais que envolvem os conceitos trabalhados, o que pode possibilitar a criação de modelos mentais mais apropriados ao conhecimento científico (SILVA JUNIOR \& PARREIRA, 2016).

Envolver os estudantes em situações que se assemelham às práticas científicas podem proporcionar oportunidades de compreensão dos conceitos, dos processos envolvidos para elaboração desses conceitos e da natureza da atividade científica. Nesta situação o estudante observa, levanta hipóteses, coleta dados, utiliza evidências para dar sentido a algum evento ou fenômeno em um ambiente de colaboração social etc. (MEYER e CRAWFORD, 2015; SOLINO et al., 2015).

Segundo Suart e Marcondes (2009), a partir de uma aula experimental, pode-se oportunizar a resolução de um problema, por meio da elaboração, teste e discussão de hipóteses, levando os estudantes a entenderem o fenômeno discutido e os conceitos envolvidos, privilegiando o desenvolvimento de habilidades cognitivas e o raciocínio lógico.

Um fator dificultador da utilização das atividades experimentais é a falta de recursos e de estrutura das escolas (PEREIRA et al., 2017). Esta situação pode ser contornada fazendo experimentos demonstrativos, em sala de aula, com materiais de baixo custo.

De acordo com Pereira et al. (2016) a experimentação é uma atividade pedagógica importante, onde o aluno pode ser entendido como o centro do processo educativo de uma ferramenta de ensino que possui princípios pedagógicos, metodológicos, epistemológicos, teóricos e filosóficos de ensinar e aprender.

Carvalho (2013) enfatiza a importância do uso de experimentos por meio de uma abordagem investigativa no processo de ensino e aprendizagem onde os professores necessitam estimular situações que fomentem o processo investigativo, colocando os estudantes frente a problemas que os levem, a partir de conceitos científicos conhecidos, construir outros ainda desconhecidos.

Hodson (1988) relata que a experimentação tem sido utilizada no ensino de Ciências visando diversos objetivos: "(i) demonstrar um fenômeno; (ii) confirmar um princípio teórico; (iii) coletar dados, testar hipóteses; (iv) desenvolver habilidades de observação ou medida; (v) adquirir familiaridade com montagens; (vi) visualizar um show de luzes, barulhos e fumaça". Ferreira et al. (2019) entendem que os objetivos propostos estão atrelados a modalidade de ensino, ou seja, uma forma pode ser mais útil que a outra em um determinado momento e corroboram com as ideias de Hodson (1988) em que a experimentação pode ser explorada para a compreensão de conceitos científicos, para entendimento de aspectos de natureza da ciência e para aproximar a investigação escolar da investigação científica.

Em uma visão mais didática Sasseron e Duschl (2016) afirmam que a experimentação pode ser usada pelos professores para: "(i) ensinar ciências, no sentido de explorar conceitos, leis e teorias científicas; (ii) ensinar sobre a ciência, que significa conhecer aspectos da natureza da ciência e dos fatores que influenciam sua prática e o entendimento de que existem intrínsecas e mútuas influências entre ciência e sociedade; (iii) ensinar como fazer ciência, no sentido de perceber a ciência como uma cultura, com normas e práticas a partir e por meio das quais se desenvolve".

Para que as atividades experimentais atinjam seus objetivos é necessário que o professor entenda as formas de abordagem da experimentação na Educação Básica e como se dá sua condução (HOFSTEIN, 2015). A figura 1 apresenta as classificações para as formas de abordagem da experimentação na Educação Básica.

Figura 1 - Classificações para as formas de abordagem da experimentação na Educação Básica

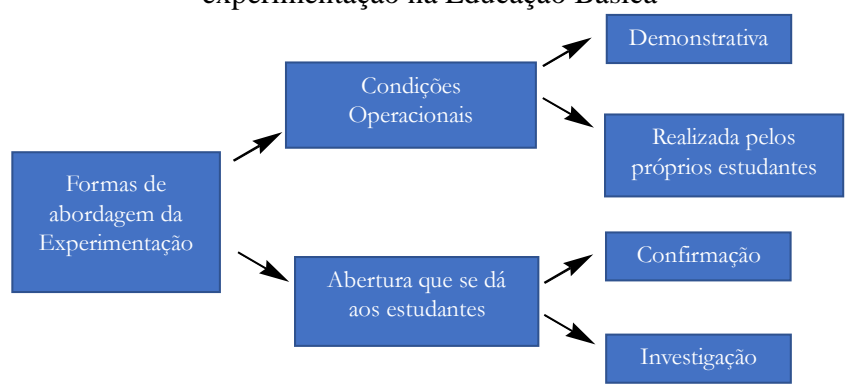

Fonte: Adaptado de Hofstein (2015).

Para Hofstein (2015), as formas de abordagem da experimentação podem ser classificadas quanto as condições operacionais e a abertura que se dá aos estudantes no momento da realização do experimento. As condições operacionais podem ser classificadas quando o experimento é realizado pelo professor (demonstrativa) e quando manipulado individualmente pelos estudantes ou em cooperação com os colegas. Para o autor, a vantagem das demonstrações está na possibilidade do professor: “(i) controlar todas as ações e dinâmica do experimento, 
podendo explicar passo-a-passo todas as etapas e o propósito desejado com a sua realização; (ii) concentrar a atenção dos estudantes em aspectos específicos os quais se deseja observar; (iii) evitar riscos à segurança dos estudantes quando os materiais são perigosos; (iv) reduzir custos com a compra de materiais para os estudantes realizarem os experimentos individualmente ou em grupos; (v) utilizar a própria sala de aula para a realização do experimento, quando não há espaço adequado para isso.

Em relação a abertura que se dá aos estudantes por meio da adaptação das ideias, a experimentação pode ser entendida como um momento de confirmação ou investigação. Na experimentação por meio da confirmação o professor planeja o experimento, debate o experimento durante a aula e fornece o procedimento a ser trabalhado na atividade. Nessa abordagem, o experimento é moderado pelo professor e os resultados conhecidos de antemão pelos estudantes. Esta situação, como afirma Carvalho (2013), proporciona ao aluno pouca oportunidade de propor situações fora do procedimento, visto que os estudantes não possuem espaço para testar suas hipóteses em relação ao fenômeno em discussão. Já numa abordagem investigativa, segundo Hofstein (2015), os experimentos são centrados nos estudantes, fazendo com que eles perguntem, planejem e controlem suas ações durante os experimentos. Nessa abordagem, os resultados não são conhecidos com antecedência pelos estudantes. De acordo com Carvalho (2013) o processo investigativo pode ocorrer tanto em experimentos realizados pelos próprios estudantes como de forma demonstrativa. Para isso a dinâmica estabelecida pelo professor deve ser questionadora em relação aos alunos antes de realizar a demonstração. Desta forma, os estudantes podem levantar hipóteses que serão testadas pelo professor para a resolução do problema. Ela ainda destaca que a resolução do problema não se encerra com a realização do experimento pelo professor, que é a etapa da ação manipulativa. A etapa final da atividade deve ser uma discussão sobre as ações executadas que levaram a solução do problema proposto.

A partir das ideias de Hodson (1988) de que a experimentação pode ser usada pelos professores para ensinar ciências, ensinar sobre a ciência e ensinar como fazer ciência, Ferreira et al. (2019) acreditam que a abordagem por meio da investigação é a mais favorável. Dessa forma, buscou-se no trabalho de Carvalho (2013) as etapas necessárias para um experimento investigativo: (i) "distribuição do material experimental e proposição do problema pelo professor"; (ii) "resolução do problema pelos estudantes"; (iii) "sistematização dos conhecimentos elaborados nos grupos"; (iv) "escrever e representar os resultados".

\section{Iniciação Científica no Ensino Médio}

O Colégio Pedro II, instituição federal tradicional do Rio de Janeiro, desenvolve desde 2014 um programa de Iniciação Científica $\mathrm{Jr}$, que visa o desenvolvimento de projetos de educação científica com estudantes da Educação Básica. Esse programa possui um relevante aspecto institucional e pedagógico, pois permite a alunos interagirem dentro desse universo experimental através do desenvolvimento de trabalhos científicos, contando com a supervisão de um professor orientador. A inserção desses jovens alunos no mundo da pesquisa propicia a descoberta de talentos, o engajamento acadêmico, a orientação vocacional e, principalmente, contribui para o aprimoramento da cultura científica, ampliando a produção acadêmico-científico-cultural na instituição.

O trabalho deve proporcionar aos alunos uma imersão na pesquisa científica em atividades que sejam adequadas à sua maturidade. A proposta foi utilizar flores do cotidiano urbano, mais especificamente as flores Ixora chinensis e Hibiscus rosa - sinensis (Figura 2), na preparação de extratos que possuam ação como indicador ácido-base em atividades experimentais realizadas no colégio. $\mathrm{O}$ trabalho atende a proposta, pois os alunos apresentam conceitos sólidos de funções inorgânicas e a função de indicadores ácido-base. Ele foi desenvolvido por duas alunas do $2^{\circ}$ ano do Ensino Médio do Campus Tijuca II.

Para Machado (2007, p.57), a atividade experimental realizada no ensino médio deve proporcionar um ensino contextualizado, investigativo e que estimule o aluno a levantar hipóteses, questionamentos e discutir sobre os fenômenos que são apresentados durante as aulas. Neste sentido, a iniciação científica realizada no Ensino Médio, proporciona o despertar desta prática, pois aproxima a Química da realidade do aluno.

Figura 2 - Flores Ixora chinensis e Hibiscus rosa - sinensis, respectivamente

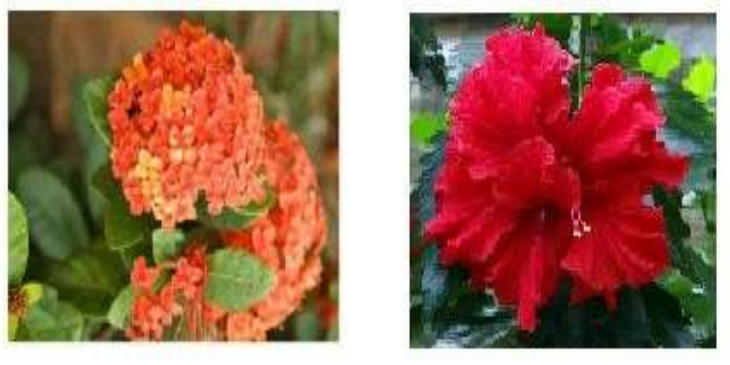

Fonte: própria.

\section{Indicadores ácido-base naturais}

Os indicadores ácido-base são substâncias orgânicas de caráter fracamente ácido ou básico, podendo ser encontrados em flores de plantas ou na casca das frutas, que apresentam cores diferentes para suas formas protonadas e desprotonadas, variando de cor em função do $\mathrm{pH}$ (ZAN et al., 2017).

Segundo Terci e Rossi (2002), os primeiros indicadores citados na literatura foram obtidos por Robert Boyle, no século XVII, quando, ao fazer um licor de violeta, percebeu que esta solução apresentava coloração vermelha, quando o meio estava ácido, e verde, em soluções básicas.

Extratos de diversos vegetais cumprem a função de indicador ácido-base, desde que possuam Antocianinas, substâncias que dão a tonalidade roxo-rosada em flores, frutos e plantas tais como: berinjela, açaí, ameixa, amora, framboesa, uva, repolho roxo e romã (TERCI \& ROSSI, 2002, p. 684). Antocianinas são pigmentos hidrossolúveis, presentes na seiva das plantas, muito delicados que podem ser transformados pela ação de luz, calor, microorganismos e variações de $\mathrm{pH}$, o que explica a sua utilização como indicador de ácido-base (LOPES et al. 2007, p. 291; UCHÔA et al., 2016) (Figura 3).

As antocianinas extraídas do meio natural aparecem na forma de sais flavílicos e, comumente, estão ligadas a moléculas de açúcares e, quando não estão, são conhecidas como antocianina (SOARES et al., 2001), as mais comuns estão representadas na Figura 4. 
Esses indicadores naturais são utilizados há mais de 200 anos, porém nas últimas décadas estão sendo substituídos por indicadores sintéticos. Apesar disso, os indicadores naturais são importantes para oferecer maior facilidade de compreensão dos conceitos químicos, por envolver o uso de poucos reagentes, materiais e por possuírem baixo custo (MARQUES, et al., 2011). A utilização de indicador ácido-base natural pode ser enquadrada no desenvolvimento de metodologias ambientalmente seguras e sustentáveis, uma tendência importante tanto no setor produtivo quanto na esfera acadêmica.

Figura 3 - Equilíbrio ácido-base das antocianidinas em função do pH

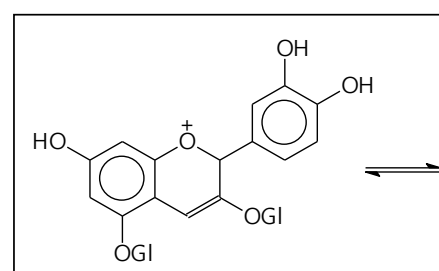

$\mathrm{pH}<3$ cátion cianina

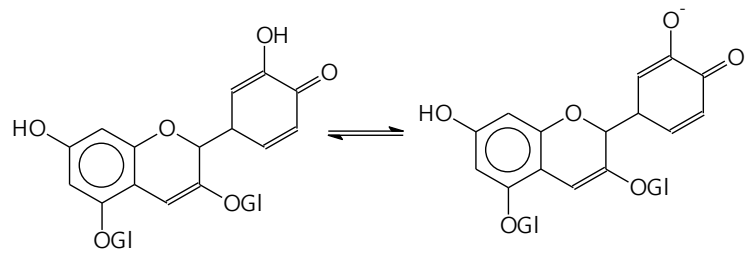

$\mathrm{pH} 8,5$ base cianina $\mathrm{pH}>8,5$ ânion cianina

*Estruturas associadas a um glicosídeo ( GI)

Fonte: Marques, et al. (2011).

\section{OBJETIVO}

Despertar o interesse científico em alunos de Ensino Médio a partir do desenvolvimento de uma metodologia que utiliza o preparo e a aplicação de extratos aquosos e hidroalcoólicos das flores presentes no cotidiano da população da cidade do Rio de Janeiro, como indicador ácido-base em soluções presentes no ambiente doméstico.

Construir uma escala de identificação de $\mathrm{pH}$ em função de cores a partir dos resultados obtidos para que possa ser utilizada em atividades experimentais em escolas de Ensino básico.

\section{METODOLOGIA}

O trabalho ocorreu a partir de encontros semanais com os alunos de iniciação científica onde se planejava cuidadosamente a execução do trabalho. As alunas passaram pelas etapas de levantamento bibliográfico, discussão da literatura, escolha das plantas utilizadas, preparo de extratos e testagem de $\mathrm{pH}$ em soluções de produtos de baixo custo encontrados em qualquer residência.

O trabalho foi desenvolvido pelas alunas sob a orientação do professor com viés investigativo.
Figura 4 - Estruturas das antocianidinas mais comuns

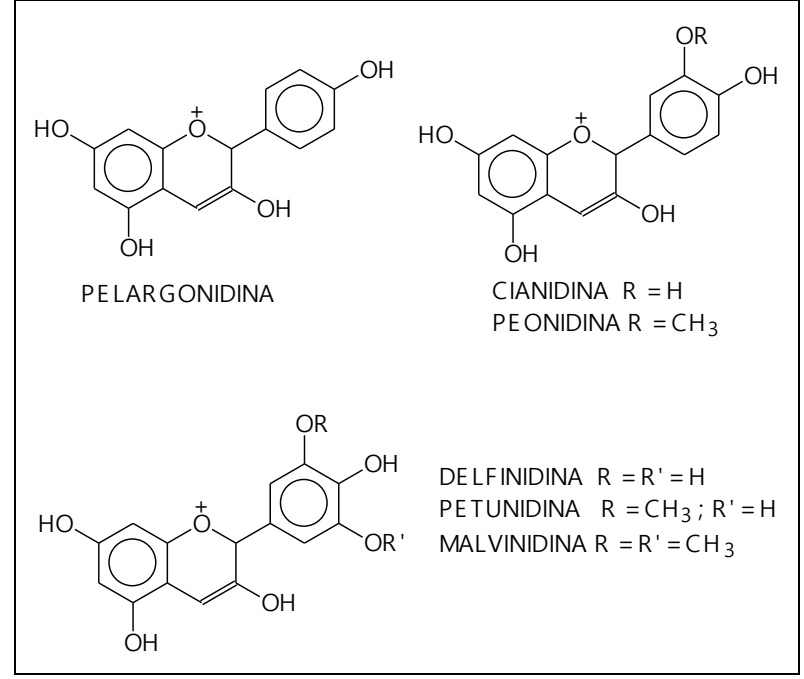

Fonte: Soares, M.H.F.B. \& Cavalheiro, E.T.G. (2001).

As flores da Ixora chinensis e da Hibiscus rosa sinensis foram coletadas da paisagem urbana da cidade do Rio de Janeiro.

\section{Extratos aquosos}

1. Em um béquer colocar as flores em pequenos pedaços;

2. Adicionar água próxima da temperatura de ebulição até cobrir toda a superfície do béquer. Tampar o recipiente com um vidro de relógio;

3. Filtrar o extrato frio e conservá-lo sob refrigeração.

\section{Extratos hidroalcóolicos}

1. Em um frasco com tampa colocar as flores em pequenos pedaços;

2. Adicionar álcool comercial $46^{\circ}$ INPM até que cubra toda a superfície, fechando-o imediatamente;

3. Aguardar o extrato por uma semana agitando ocasionalmente;

4. Filtrar o extrato frio e conservá-lo sob refrigeração.

As soluções indicadoras foram testadas em produtos domésticos como: detergente, limão, sal de cozinha, hidratante corporal, xampu, sabonete, álcool, amoníaco, água sanitária, leite de magnésia e bicarbonato de sódio. Os sólidos foram previamente dissolvidos em água.

A análise foi feita colocando $2 \mathrm{ml}$ do produto em análise em um tubo de ensaio seguida do gotejamento, com agitação, da solução indicadora, anotando a coloração observada.

Os resultados foram registrados por fotos.

\section{RESULTADOS E DISCUSSÃO}

O trabalho foi desenvolvido ao longo de oito meses e observou-se um crescimento tanto de conhecimento quanto das habilidades das alunas. Pode-se perceber além da motivação uma boa percepção das etapas que devem ser trabalhadas em um processo científico. Este resultado está 
de acordo com o proposto por Carvalho (2013). Acredito que isto se deva principalmente pelo trabalho ter sido desenvolvido pelas alunas com viés investigativo.

A proposta foi cumprida integralmente e o trabalho apresentado na forma de banner na Semana Cultural do Campus Tijuca II do Colégio Pedro II (Figura 5) e na III Jornada de Iniciação Científica do Colégio Pedro II onde os alunos puderam demonstrar para a comunidade escolar, professores, alunos e familiares o trabalho desenvolvido. A culminância ocorreu na apresentação do trabalho, na forma Roda de Conversa, no I Encontro da Rede Rio de Ensino de Química realizado em Macaé.

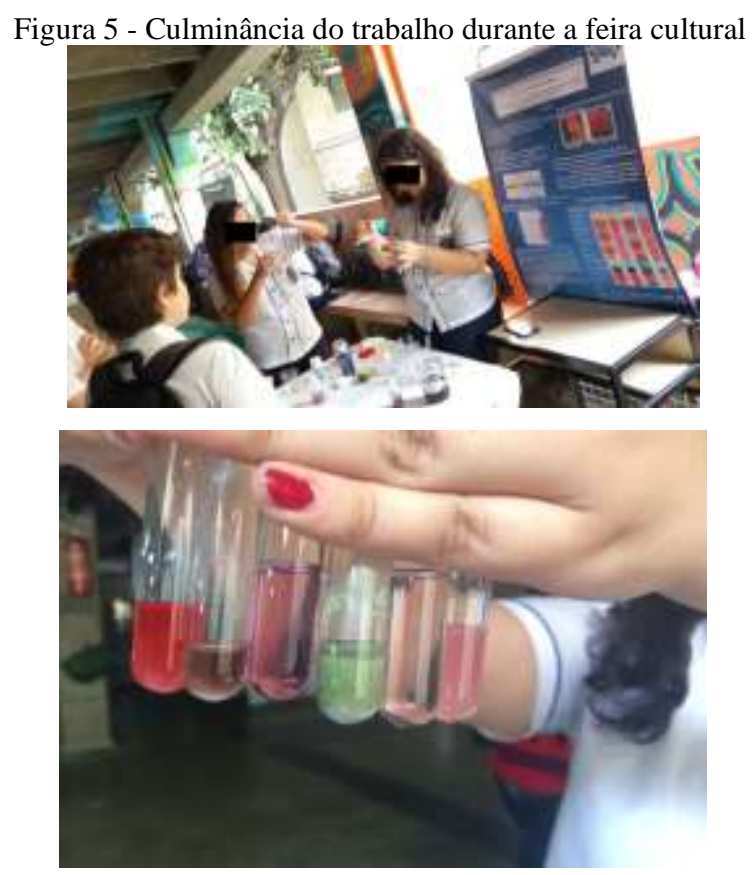

Fonte: própria.

As cores obtidas pela interação dos indicadores com os produtos analisados estão colocadas na Figura 6. Os dados de $\mathrm{pH}$ apresentados foram obtidos da literatura.

Os extratos foram eficientes como indicador ácidobase visto que puderam diferenciar, através da mudança de cor, soluções de caráter ácido e básico. Não foi observada diferença significativa de cores entre o extrato aquoso e o hidroalcoólico de uma mesma espécie vegetal. Em relação às duas flores utilizadas observou-se que os extratos de Hibiscus rosa proporcionaram uma melhor diferenciação dos $\mathrm{pH}$ de caráter ácido.

Os indicadores apresentam colorações distintas em relação a substâncias de caráter básico de diferentes $\mathrm{pH}$ como bicarbonato de sódio $(8,2)$, leite de magnésia $(10,5)$, amoníaco $(11,5)$ e água sanitária $(12,5)$, assim como de caráter ácido como suco de limão (2-3) e sabonete (5-6).

A utilização de indicadores ácido-base provenientes de produtos naturais ao invés dos sintéticos apresenta vantagens, pois representam um conceito mais sustentável. Quando se utiliza indicadores sintéticos em uma prática de identificação ácido-base não se pensa no custo da sua produção. Um exemplo é a fenolftaleína, um dos indicadores mais usados em laboratório, que é produzida a partir de fenol e anidrido ftálico, com um rendimento em torno de $80 \%$. Além do efeito tóxico, a produção de uma substância química via rota sintética utiliza etapas de purificação com o uso de solventes, o que aumenta a carga de poluidores ao ambiente.
Figura 6 - Ação do indicador nos produtos analisados

\begin{tabular}{|c|c|c|c|c|c|}
\hline \multirow{2}{*}{$\begin{array}{l}\text { Soluçăo } \\
\text { Amnlisadn }\end{array}$} & \multirow{2}{*}{$\mathrm{pH}$} & \multicolumn{2}{|c|}{ DXORA } & \multicolumn{2}{|c|}{ HIBISCUS } \\
\hline & & $\begin{array}{l}\text { Fidiro } \\
\text { slcoolice }\end{array}$ & Aqw0050 & $\begin{array}{c}\text { Fidro } \\
\text { alcootico }\end{array}$ & Aqwoso \\
\hline $\begin{array}{c}\text { Suco do } \\
\text { linslo }\end{array}$ & 223 & & & & \\
\hline Fijuratante & 5,5 & & & & \\
\hline Xsmpu & $5 \mathrm{a} 6,5$ & & & & \\
\hline Sabonste & $5-6$ & & & & \\
\hline Dotergonte & 7,0 & & & & \\
\hline $\begin{array}{l}\text { Sal do } \\
\text { corinha }\end{array}$ & 7,0 & & & & \\
\hline $\mathrm{NaHCO}_{3}$ & 8,2 & & & & \\
\hline $\begin{array}{l}\text { Leito do } \\
\text { maggenin }\end{array}$ & 10,5 & & & & \\
\hline Amontaco & 11,5 & & & & \\
\hline $\begin{array}{c}\text { Aggua } \\
\text { samithria }\end{array}$ & 12,5 & & & & \\
\hline
\end{tabular}

Fonte: própria.

\section{CONCLUSÃO}

A proposta de desenvolver trabalhos de iniciação científica, na área de Química, no Ensino Médio apresentou resultados satisfatórios, pois as atividades estavam compatíveis com a maturidade e o conhecimento dos alunos.

O trabalho desenvolvido pelas alunas proporcionou uma experiência científica importante no desenvolvimento de suas potencialidades.

Os extratos das flores estudadas apresentaram um bom potencial como indicador ácido-base e podem ser usados em atividades experimentais como alternativa para o extrato do repolho roxo.

O trabalho serve como modelo para a construção de diversas escalas de $\mathrm{pH}$ a partir de extratos aquosos ou hidroalcoólicos de produtos do cotidiano que apresentam antocianidinas. Devido a utilizar materiais simples pode ser realizado pelos alunos com viés investigativo sem que apresente um perigo potencial a sua segurança.

O trabalho é adequado para atividades experimentais utilizadas ao longo do Ensino Médio, principalmente no ensino de Funções Inorgânicas, Reações Inorgânicas e Hidrólise Salina.

A utilização de atividades científicas mais sustentáveis proporciona aos alunos apresentar a Química como protagonista, mostrando toda sua capacidade, colocando-a num papel de destaque na reconstrução de um mundo social e ambientalmente isento de uma carga tóxica excessiva.

\section{REFERÊNCIAS}

ANDRADE, M.L. F; MASSABNI, V.G. O desenvolvimento de atividades práticas na escola: Um desafio para os professores de Ciências. São Paulo, Ciência \& Educação, v. 17, n. 4, p 835-854, 2011.

CARVALHO, A. M. P. O ensino de ciências e a proposição de sequências de ensino investigativas. In: CARVALHO, A. M. P. (org.). Ensino de ciências por investigação: condições para implementação em sala de aula. São Paulo: Cengage Learning, p. 1-20, 2013.

FERNANDES, R. C. A. Matemática e Pokemath: motivação e inovação pedagógica no Ensino de Matemática. Revista 
Sodebras [On line], v. 12, n. 136, p. 101-106, 2017. Disponível

http://www.sodebras.com.br/edicoes/N136.pdf. Acesso em: 28/09/2020.

FERREIRA, S.; CORRÊA, R.; SILVA, F.C. Estudo dos roteiros de experimentos disponibilizados em repositórios virtuais por meio do ensino por investigação. Ciência \& Educação (Bauru), v. 25, n. 4, p. 999-1017, 2019.

GIORDAN, M. O Papel da Experimentação no Ensino de Ciências. Química Nova na Escola, n. 10, p. 43-49, 1999.

GUIMARÃES, C.C. Experimentação no Ensino de Química: Caminhos e descaminhos rumo à aprendizagem significativa. São Paulo. Química Nova na Escola, Vol. 31, n. 3, p. 198-202, 2009.

HODSON, D. Experiments in science and science teaching. Educational Philosophy and Theory, Abingdon, v. 20, n. 2, p. 53-66, 1988. DOI: https://doi. org/10.1111/j.14695812.1988.tb00144.x.

HOFSTEIN, A. Laboratory work, forms of. In: GUNSTONE R, R. (ed.). Encyclopedia of science education. Dordrecht: Springer, p. 563-566, 2015.

IZQUIERDO, M.; SANMARTÍ, N. e ESPINET, M. Fundamentación y diseño de las prácticas escolares de ciencias experimentales. Enseñanza de las Ciencias, v. 17, n. 1, p. 45-60, 1999.

LOPES, T.J.; XAVIER, M.F.; QUADRI, M.G.N.; QUADRI, M.B. Antocianinas: Uma breve revisão das características estruturais e da estabilidade. Revista Brasileira de Agrociência, v. 13, n.3, p. 291-7, 2007.

MACHADO, P. F. L. e MÓL, G. S. Experimentando Química com Segurança. Química Nova na Escola, n. 27, 57-60, 2007.

MARQUES, J. A.; BIAZOTO, K.; de BIASI, L. H.; DOMINGUINI, L. Estudo do comportamento de antocianinas como indicadores naturais. Criciuma. $\mathbf{1}^{\mathbf{0}}$ Seminário de Pesquisa, Extensão e Inovação do IFSC, 2011.

MEYER, X. S.; CRAWFORD, B. A. Multicultural Inquiry Toward Demystifying Scientific Culture and Learning Science. Science Education. v. 99, 617-637, 2015.

PEREIRA, A. S.; VITURINO, J. P.; ASSIS, A. Ouso de indicadores naturais para abordar a experimentação investigativa problematizadora em aulas de Química. Educação Química em Ponto de Vista, v. 1, p 135-148, 2017.

PEREIRA, C. L.; TORRES, M. L. S.; PIRES, F. P.; ROSSINI, W. A.; GONÇALVES, E. L. O. o Ensino de Ciências da Natureza: Estratégias Metodológicas (Des)contextualizadas para Educação Escolar do campo. Revista Sodebras [On line], v. 11, n. 127, p. 12-18, 2016. Disponível em: http://www.sodebras.com.br/edicoes/N127.pdf. Acesso em: 28/09/2020.

SASSERON, L. H.; DUSCHL, R. Ensino de ciências e as práticas epistêmicas: o papel do professor e o engajamento dos estudantes. Investigações em Ensino de Ciências, Porto Alegre, v. 21, n. 2, p. 52-6, 2016.
SOARES, M.H.F.B.; CAVALHEIRO, E.T.D. Aplicação de extratos brutos de flores de quaresmeira e azaleia e da casca de feijão preto em volumetria ácido-base. Um experimento para cursos de análise quantitativa. Química Nova, v. 24, n. 3, p. 408-411, 2001.

SOLINO, A. P.; FERRAZ, A. T.; SASSERON, L. H. Ensino por Investigação como abordagem didática: desenvolvimento de práticas científicas escolares, XXI Simpósio Nacional de Ensino de Física, Uberlândia, MG, 2016. Disponível em: http://www.sbf1.sbfisica.org.br/eventos/snef/xxi/sys/resumo s/T0254-1.pdf Acesso em: 28/09/2020.

SILVA JUNIOR, E.A.; PARREIRA, G.G. Reflexões sobre a importância da experimentação no ensino da química no Ensino Médio. Tecnia, Revista de Educação, Ciência e Tecnologia do IFG, v. 1, n. 1, p. 67-81, 2016.

SUART, R. C.; MARCONDES, M. E. R. A manifestação de habilidades cognitivas em atividades experimentais investigativas no ensino médio de química. Ciências \& Cognição, Rio de Janeiro, v. 14, n. 1, p. 50-74, 2009.

TERCI, D.B.L.; ROSSI, A.V. Indicadores Naturais de pH: Usar papel ou solução? Química Nova, v. 25, n. 4, p. 684-8, 2002.

UCHÔA, V. T.; CARVALHO FILHO, R. S. M.; LIMA, A, M, M.; ASSIS, J. B. Utilização de plantas ornamentais como novos indicadores naturais ácido-base no Ensino de Química. Holos, v. 2, p. 152-165, 2016.

ZAN, A. S. H. S.; FAUSTINO, E.; BAPTISTA, J. A. A.; ZAN, R. A. Obtenção e uso de indicadores naturais em uma escola de Ji-Paraná-Rondônia, Amazônia Ocidental - Brasil. Revista Debates em Ensino de Química, v. 3, p. 188-200, 2017.

\section{COPYRIGHT}

Direitos autorais: Os autores são os únicos responsáveis pelo material incluído no artigo.

Submetido em: 05/09/2020 Aprovado em: 30/09/2020 


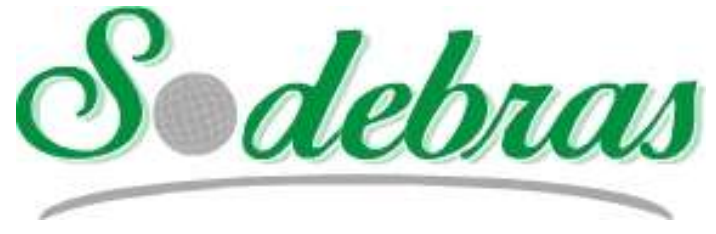

\author{
Revista SODEBRAS - Volume 15 \\ $\mathrm{N}^{\circ} 178$ - OUTUBRO/ 2020
}

\title{
GERAÇÃO COMPARTILHADA DE ENERGIA ELÉTRICA ATRAVÉS DE CONSÓRCIOS E COOPERATIVAS
}

\section{SHARED GENERATION OF ELECTRICITY THROUGH CONSORTIUMS AND COOPERATIVES}

\author{
ALLANA DE MOURA NETTO ${ }^{1}$; JAIR URBANETZ JUNIOR ${ }^{1}$; AMÉRICO VICENTE TEIXEIRA LEITE ${ }^{2}$ \\ 1 - UNIVERSIDADE TECNOLÓGICA FEDERAL DO PARANÁ; 2 - INSTITUTO POLITÉCNICO DE \\ BRAGANÇA \\ allana@alunos.utfpr.edu.br;urbanetz@utfpr.edu.br;avtl@ipb.pt
}

\begin{abstract}
Resumo - A geração compartilhada de energia elétrica através de consórcios ou cooperativas é a solução para consumidores que desejam investir em fontes alternativas de energia, mas não possuem área disponivel em seu terreno ou condições financeiras para tal. Nos consórcios e nas cooperativas o custo de instalação da geração é dividido entre os participantes, se tornando reduzido quando comparado a aquisição individual de usinas. Por esses $e$ outros motivos, a geração compartilhada é uma modalidade negocial com tendência de crescimento no Brasil nos próximos anos. Para que essa modalidade seja bem aproveitada, esse artigo apresenta uma breve interpretação legislativa, esclarece os conceitos envolvidos na geração compartilhada e verifica estudos de viabilidade econômico-financeira.
\end{abstract}

Palavras-chave: Geração Compartilhada. Consórcio. Cooperativa.

\begin{abstract}
The shared generation of electricity through consortia or cooperatives is the solution for consumers who want to invest in alternative energy sources, but do not have an available area on their land or financial conditions to do so. In consortia and cooperatives the cost of installing the generation is divided among the participants, becoming reduced when compared to the individual acquisition of power plants. For these and other reasons, shared generation is a business modality with a growth trend in Brazil in the coming years. For this modality to be well used, this article presents a brief legislative interpretation, clarifies the concepts involved in shared generation and verifies studies of economic and financial viability.
\end{abstract}

Keywords: Shared Generation. Consortium. Cooperative.

\section{INTRODUÇÃO}

No Brasil, a Geração Distribuída (GD) teve um elevado crescimento nos últimos anos devido principalmente aos incentivos regulatórios. Esses incentivos surgiram a partir de publicações de Resoluções Normativas pela Agência Nacional de Energia Elétrica (ANEEL). A Resolução Normativa n ${ }^{\circ} 482$ de 2012 (REN 482/2012) da ANEEL, atualizada pela Resolução Normativa $n^{\circ} 687$ de 2015 (REN 687/2015), forneceu condições para a inserção de GD na rede elétrica, através do Sistema de Compensação de energia elétrica. Esse sistema permite a injeção na rede elétrica de energia ativa produzida através de GD em uma Unidade Consumidora (UC) e, posteriormente, essa energia é abatida no faturamento de energia dessa UC.

Particularmente, a REN 687/2015 ampliou as possibilidades da REN 482/2012, criando outros modelos negociais de GD. Dentre esses modelos, a geração compartilhada se apresenta como uma alternativa extremamente interessante, principalmente para consumidores que não possuem condições de instalar GD em seu terreno, seja por limitações físicas (sem área disponível), econômicas ou outras.

A modalidade de geração compartilhada ainda é incipiente no Brasil, quando comparada com as modalidades de GD junto à carga e o autoconsumo remoto (ANEEL, 2020). Apesar disso, as vantagens apresentadas dessa modalidade negocial indicam que, apesar de ainda pouco explorada no Brasil, essa possui alta potencialidade de aplicação. Esse contraste evidencia a importância desse estudo, uma vez que ele revela o grande potencial existente nessa modalidade.

Nesse sentido, para que a geração compartilhada seja bem aproveitada, torna-se importante um estudo das possibilidades estabelecidas pela legislação brasileira, com a devida interpretação da REN 687/2015. Também é relevante entender os conceitos envolvidos na geração compartilhada e verificar estudos de viabilidade econômico-financeira dessa modalidade de GD.

\section{PRINCIPAIS MEDIDAS ESTABELECIDAS PELA REN 687/2015}

A seguir são descritas as principais diretrizes determinadas pela REN 687/2015, enfatizando as suas alterações em relação à REN 482/2012.

\section{1 - Ampliação das fontes}

A norma estende as fontes para renováveis e cogeração qualificada. Dessa forma, a fonte pode ser qualquer energia renovável: solar, hidráulica, eólica, biomassa, maremotriz, geotérmica, entre outras.

\section{2 - Definição dos limites de potência}

Microgeração é a geração de 0 até $75 \mathrm{~kW}$ e se for acima de $75 \mathrm{~kW}$ e abaixo de $5 \mathrm{MW}$, trata-se de uma minigeração. No caso das hidráulicas, o limite da minigeração é menor (3 MW). 


\section{3 - Duração dos créditos de energia}

Os créditos de energia no Sistema de Compensação duram até 60 meses ( 5 anos).

\section{4 - Melhoria na fatura de energia}

As distribuidoras, quando faturarem os consumidores no modelo do Sistema de Compensação, devem demonstrar explicitamente o quanto foi gerado e consumido, qual a fatura de energia daquele mês e o porcentual de créditos que aquele consumidor possui.

\section{5 - Simplificação de acesso}

Todo o processo para acesso da GD à rede elétrica nos termos do Sistema de Compensação deve ser realizado online.

\section{6 - Vedações}

A norma não permite que ocorra a divisão de uma central geradora maior em outras menores de $5 \mathrm{MW}$ e também proíbe o pagamento do terreno no qual o consumidor vai colocar a GD de maneira proporcional à energia elétrica.

\section{7 - Participação financeira}

O consumidor pode ter a obrigação de participar financeiramente das obras necessárias para o seu atendimento. A regra da participação financeira é válida para os consumidores com minigeração ou microgeração na forma de geração compartilhada.

\section{8 - Medição}

O instrumento de medição deve ser alterado de um unidirecional para um bidirecional. Essa alteração só é paga pelo consumidor se for minigeração ou microgeração na forma de geração compartilhada.

\section{9 - Procedimento de conexão de GD com a rede}

A Figura 1 demonstra a sequência de ações que devem ser realizadas pelo consumidor e pela distribuidora para a conexão da GD com a rede.

\section{Figura 1 - Procedimentos e etapas de acesso}

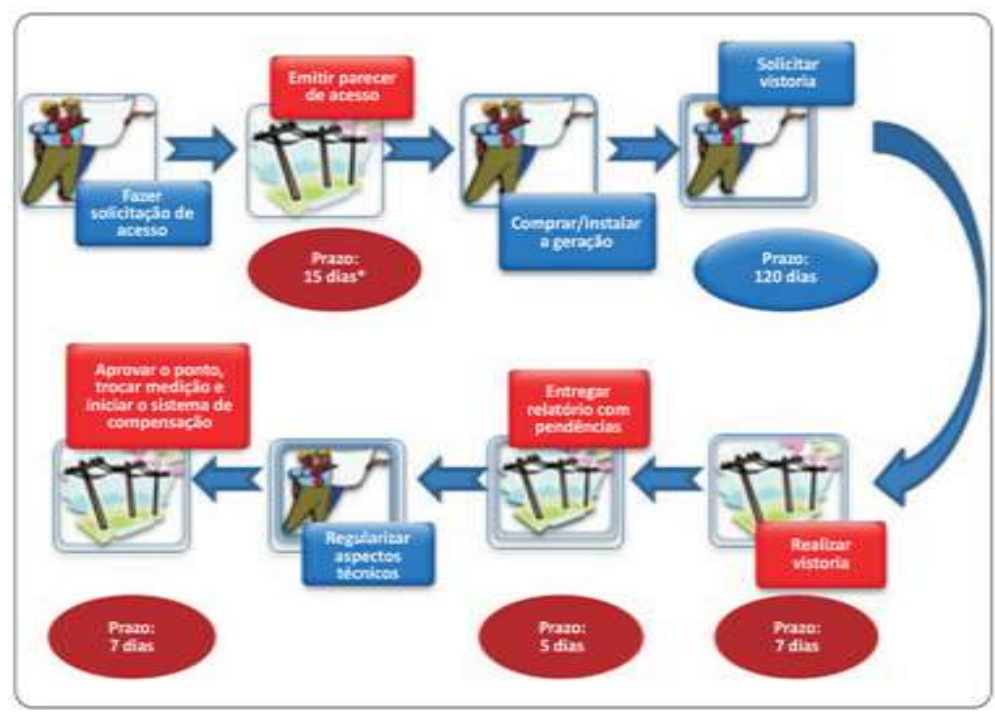

Fonte: ANEEL, 2016

\subsection{0 - Modalidades negociais de GD}

Atualmente, existem quatro modelos negociais de GD: GD junto à carga, condomínio com GD, autoconsumo remoto e GD compartilhada (ANEEL, 2015). Em todos esses, os consumidores têm que estar na mesma área de concessão, ou seja, em área atendida pela mesma distribuidora de energia. Apesar desse aspecto em comum, cada um dos quatro modelos possui a sua particularidade. As singularidades de cada um são detalhadas nos itens a seguir.

\subsection{1 - GD junto à carga}

A GD junto à carga é simplesmente aquela na qual o consumidor possui uma carga e deseja instalar uma GD próxima à sua carga. A GD junto à carga é representada, por exemplo, por um consumidor que deseja instalar um painel fotovoltaico em seu telhado.

\subsection{2 - Condomínios com GD}

Nessa modalidade, os consumidores que moram em um condomínio, vertical (por exemplo, um edifício) ou horizontal (por exemplo, um shopping, um condomínio residencial ou comercial), podem colocar a GD em uma área comum e utilizar os créditos dessa GD.

\subsection{3 - Autoconsumo Remoto}

Uma outra possibilidade negocial é a de autoconsumo remoto. Trata-se de um consumidor que possui mais de uma UC em seu nome (de sua titularidade) na mesma área de concessão. Nesse caso, o consumidor vai utilizar os créditos a mais que forem gerados em uma UC de sua titularidade para abater a fatura de energia de outra UC, também de sua titularidade. O registro da titularidade pode ser através de um CPF ou CNPJ (matriz ou filial). 


\section{GERAÇÃO COMPARTILHADA}

A quarta e última modalidade é a de geração compartilhada, que se refere a um conjunto de consumidores que estão em locais distintos (não precisam ser vizinhos) que se unem através de um consórcio ou uma cooperativa (composta de pessoa física ou jurídica) e instalam uma GD. Esses consumidores vão instalar a GD em uma UC (que não precisa necessariamente ter consumo) de titularidade do consórcio ou da cooperativa. Nesse modelo, o excedente gerado nessa UC, ou seja, o que foi gerado menos o que foi consumido nessa UC, é utilizado para abater o consumo de várias outras UCs em porcentagens definidas previamente pelo consórcio ou pela cooperativa.

Adiante, são apresentados os conceitos de consórcio, cooperativa e as principais diferenças e semelhanças entre esses.

\section{1-Consórcio}

De acordo com Lima (2018), os consórcios de GD reúnem empresas que firmam um contrato entre si para se beneficiarem das vantagens do compartilhamento de recursos na implantação de uma geração compartilhada. Regulado pela Lei $n^{\circ}$ 6.404/1976, o consórcio precisa se inscrever no CNPJ e ser o titular da UC onde será instalada a GD (LIMA, 2018). Ainda, a regulação da ANEEL permite que os consórcios criados em conformidade com a Lei $\mathrm{n}^{\circ} 11.795 / 2008$ também possam aderir ao Sistema de Compensação. Como esses consórcios não possuem personalidade jurídica nem são escritos no CNPJ, a administradora será a titular da UC onde o gerador estiver instalado (LIMA, 2018). Ilustradamente, o consórcio é representado na Figura 2.

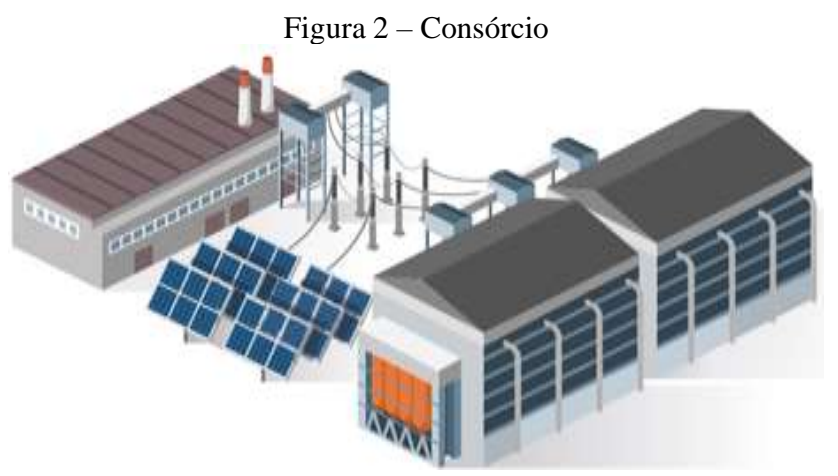

Fonte: Lima, 2018.

\section{2 - Cooperativa}

Uma cooperativa trata-se de uma associação de pessoas voluntariamente reunidas para buscar satisfazer as suas necessidades e aspirações econômicas, sociais e culturais comuns (LIMA, 2018). Desta forma, um grupo de pelo menos vinte pessoas pode constituir uma cooperativa para produzir a própria energia, que será distribuída na forma de créditos em $\mathrm{kWh}$ na conta de energia elétrica entre os cooperados, em percentuais previamente aprovados por todos (LIMA, 2018). De forma ilustrativa, a cooperativa pode ser visualizada na Figura 3.

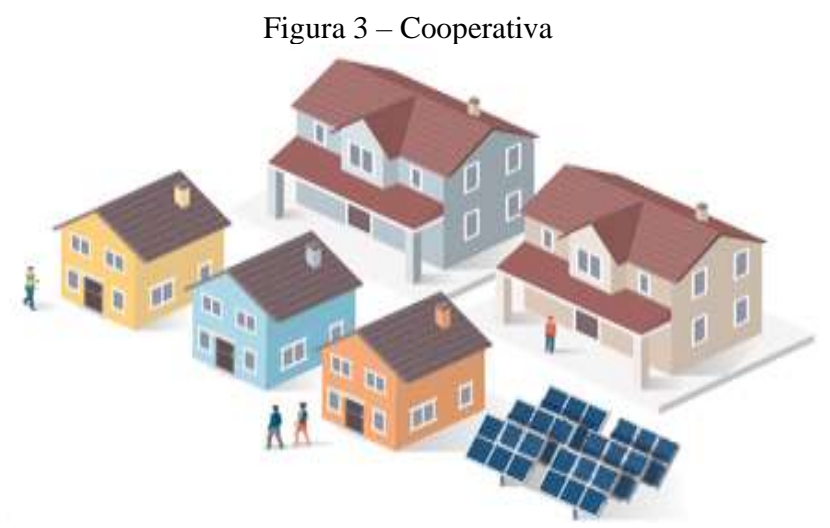

Fonte: Lima, 2018.

\section{3 - Comparação entre Consórcio e Cooperativa}

As principais diferenças entre o consórcio e a cooperativa estão apresentadas na Tabela 1 .

Tabela 1 - Principais diferenças entre consórcio e cooperativa

\begin{tabular}{|c|c|c|}
\hline Diferenças & $\begin{array}{l}\text { Consórcio } \\
\end{array}$ & Cooperativa \\
\hline Motivação/criação & $\begin{array}{l}\text { Promovida por uma } \\
\text { administradora, para } \\
\text { a prestação de um } \\
\text { serviço comum a um } \\
\text { grupo de pessoas } \\
\text { interessadas }\end{array}$ & $\begin{array}{c}\text { Reunião de } \\
\text { pessoas com os } \\
\text { mesmos } \\
\text { interesses }\end{array}$ \\
\hline $\begin{array}{l}\text { Natureza dos seus } \\
\text { integrantes }\end{array}$ & $\begin{array}{l}\text { Pessoas físicas e } \\
\text { jurídicas sem } \\
\text { nenhuma limitação }\end{array}$ & $\begin{array}{l}\text { Pessoas físicas } \\
\text { e jurídicas, } \\
\text { desde que as } \\
\text { pessoas } \\
\text { jurídicas não } \\
\text { operem no } \\
\text { mesmo campo } \\
\text { econômico da } \\
\text { sociedade } \\
\end{array}$ \\
\hline $\begin{array}{c}\text { Forma de } \\
\text { financiamento }\end{array}$ & Autofinanciamento & $\begin{array}{c}\text { Mercado e } \\
\text { financiamento }\end{array}$ \\
\hline $\begin{array}{l}\text { Tempo de } \\
\text { duração }\end{array}$ & $\begin{array}{l}\text { Prazo determinado, } \\
\text { coincide com o } \\
\text { término da prestação } \\
\text { de serviço em } \\
\text { contrato } \\
\end{array}$ & Indeterminado \\
\hline Responsabilidade & Previsto em contrato & $\begin{array}{c}\text { Limitado a } \\
\text { quantidade de } \\
\text { quotas ou } \\
\text { utilização do } \\
\text { serviço } \\
\text { prestado } \\
\end{array}$ \\
\hline $\begin{array}{l}\text { Relação entre os } \\
\text { integrantes }\end{array}$ & $\begin{array}{c}\text { A cooperação entre } \\
\text { os integrantes é } \\
\text { limitada pelo } \\
\text { contrato }\end{array}$ & $\begin{array}{c}\text { Sempre } \\
\text { pensando em } \\
\text { um grupo } \\
\text { como um todo }\end{array}$ \\
\hline
\end{tabular}

Fonte: Paris Junior et al., 2018.

Como semelhanças das duas associações, essas devem deter propriedade ou posse direta de área com GD, os equipamentos utilizados na GD podem ser alugados ou arrendados, devem garantir instrumento jurídico que comprove o compromisso de solidariedade entre os associados perante a distribuidora e o percentual da energia que será destinado a cada UC deve ser informado à distribuidora previamente (GREENER, 2017). 


\section{4 - Dados da Geração Compartilhada no Brasil}

Nessa seção são apresentados levantamentos de dados da geração compartilhada no país. Em uma primeira análise, verifica-se que existe uma tendência de aumento dessa modalidade no Brasil, através da Figura 4.

Figura 4 - Quantidade anual de conexão de geração compartilhada no Brasil

\section{Quantidade Anual de Conexão de Geração Compartilhada no Brasil}

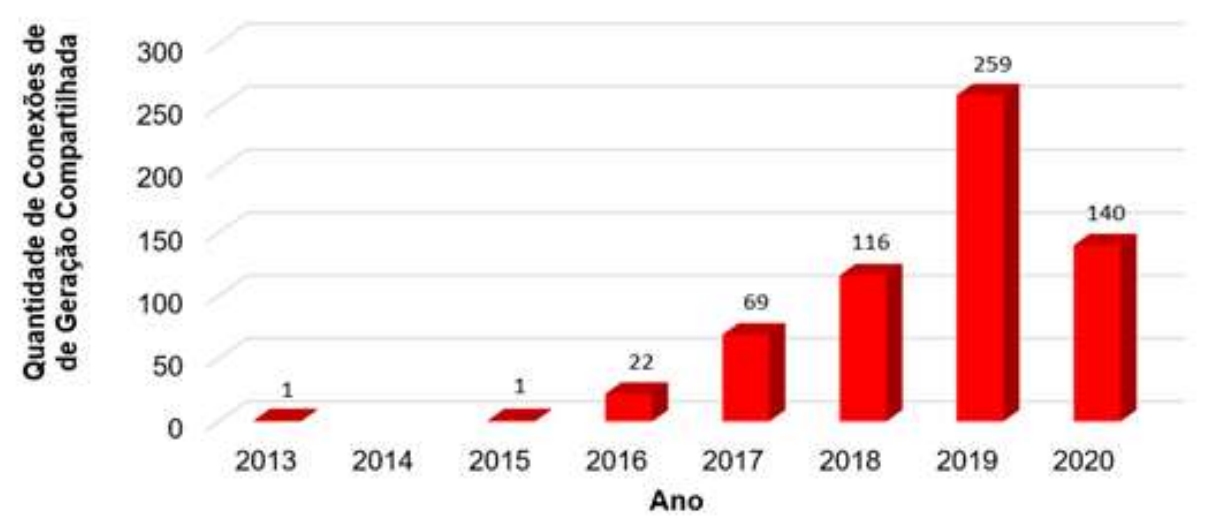

Fonte: Adaptado de ANEEL, 2020.

Até julho de 2020, foram cadastrados na ANEEL 608 empreendimentos de geração compartilhada, totalizando 39,25 MW de potência instalada, com 2.293 UCs recebendo os créditos de energia em 289 municípios brasileiros (ANEEL, 2020). A Tabela 2 apresenta os dados de geração compartilhada, divididos em micro e minigeração. Através dessa tabela, nota-se que aproximadamente $78 \%$ da potência instalada dos empreendimentos de geração compartilhada são de minigeração, que representam somente $5 \%$ dos empreendimentos.
Tabela 2 - Micro e minigeração no modelo de geração

\begin{tabular}{c|c|c}
\multicolumn{1}{c}{} & \multicolumn{2}{c}{ compartilhada } \\
\cline { 2 - 3 } & $\mathbf{N}^{\circ}$ Unidades & $\begin{array}{c}\text { Potência } \\
\text { Instalada }(\mathbf{k W})\end{array}$ \\
\hline Microgeração & 576 & $8.639,39$ \\
\hline Minigeração & 32 & $30.613,12$ \\
\hline TOTAL & $\mathbf{6 0 8}$ & $\mathbf{3 9 . 2 5 2 , 5 1}$ \\
\hline
\end{tabular}

Fonte: Adaptado de ANEEL, 2020.

Em relação à fonte de geração, a fonte solar fotovoltaica destaca-se notadamente na modalidade de geração compartilhada, sendo utilizada em cerca de 97\% dos empreendimentos desse modelo (Figura 5) (ANEEL, 2020).

Figura 5 - Geração compartilhada no Brasil por fonte de geração

\section{Geração Compartilhada no Brasil por Fonte de}

\section{Geração}

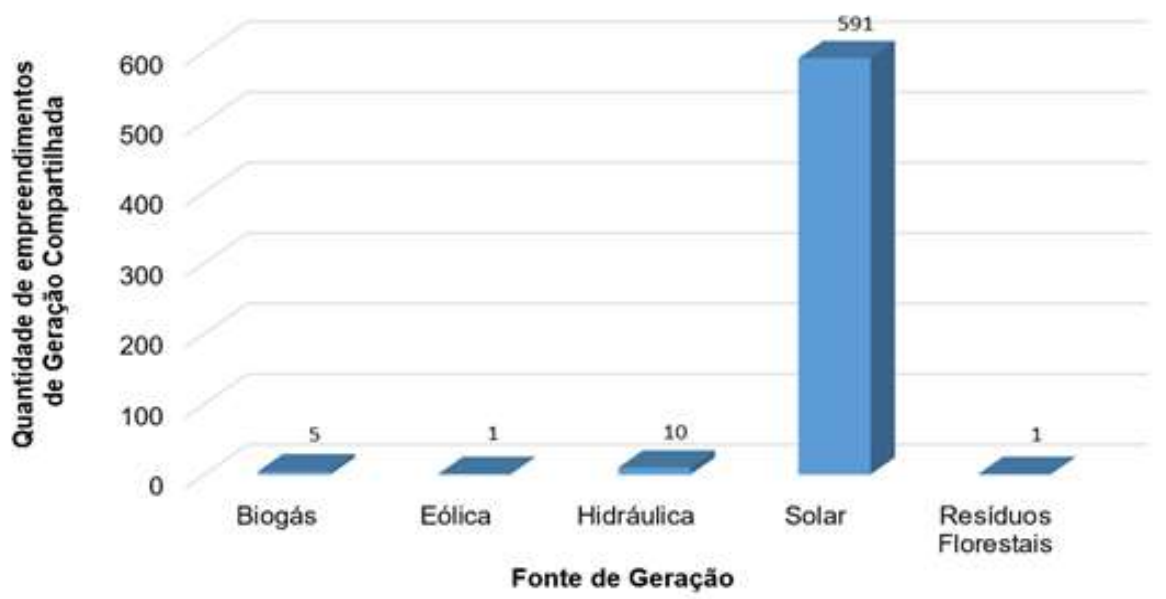

Fonte: Adaptado de ANEEL, 2020.

No que diz respeito aos estados brasileiros, o estado que se destaca pelo maior número de unidades de geração compartilhada atualmente é São Paulo, com 150 empreendimentos. Em capacidade instalada, Rondônia está no primeiro lugar entre os estados brasileiros (com 9.153,06 $\mathrm{kW}$ ), apesar de ter um número menor de unidades desse empreendimento do que outros estados. A Tabela 3 apresenta os dados de geração compartilhada no Brasil por estado e a Figura 6 ilustra a concentração desses empreendimentos no mapa geográfico do Brasil. Na Figura 6 é visível que as regiões sul e sudeste do Brasil concentram $71 \%$ das unidades de geração compartilhada (ANEEL, 2020). 
Tabela 3 - Geração compartilhada no Brasil por estado

\begin{tabular}{|c|c|c|}
\hline Estado & $\begin{array}{c}\mathrm{N}^{\circ} \\
\text { Unidades }\end{array}$ & $\begin{array}{c}\begin{array}{c}\text { Potência Instalada } \\
(\mathrm{kW})\end{array} \\
\end{array}$ \\
\hline Bahia & 5 & 20,38 \\
\hline Ceará & 2 & $5.010,00$ \\
\hline Espírito Santo & 2 & $1.013,60$ \\
\hline Goiás & 1 & 3,50 \\
\hline Maranhão & 1 & $1.056,00$ \\
\hline Minas Gerais & 32 & $4.407,70$ \\
\hline Mato Grosso do Sul & 3 & $1.085,41$ \\
\hline Mato Grosso & 3 & 90,84 \\
\hline Pará & 1 & 17,32 \\
\hline Paraíba & 1 & 1,50 \\
\hline Pernambuco & 3 & 521,80 \\
\hline Piauí & 9 & 100,94 \\
\hline Paraná & 2 & 87,20 \\
\hline Rio de Janeiro & 69 & 851,21 \\
\hline Rio Grande do Norte & 44 & 496,86 \\
\hline Rondônia & 28 & $9.153,06$ \\
\hline Roraima & 8 & 287,60 \\
\hline Rio Grande do Sul & 94 & $1.860,48$ \\
\hline Santa Catarina & 83 & $3.751,64$ \\
\hline Sergipe & 50 & 726,24 \\
\hline São Paulo & 150 & $8.333,63$ \\
\hline Tocantins & 17 & 375,60 \\
\hline TOTAL & 608 & 39.252,51 \\
\hline
\end{tabular}

Fonte: Adaptado de ANEEL, 2020.

Figura 6 - Empreendimentos de geração compartilhada no Brasil

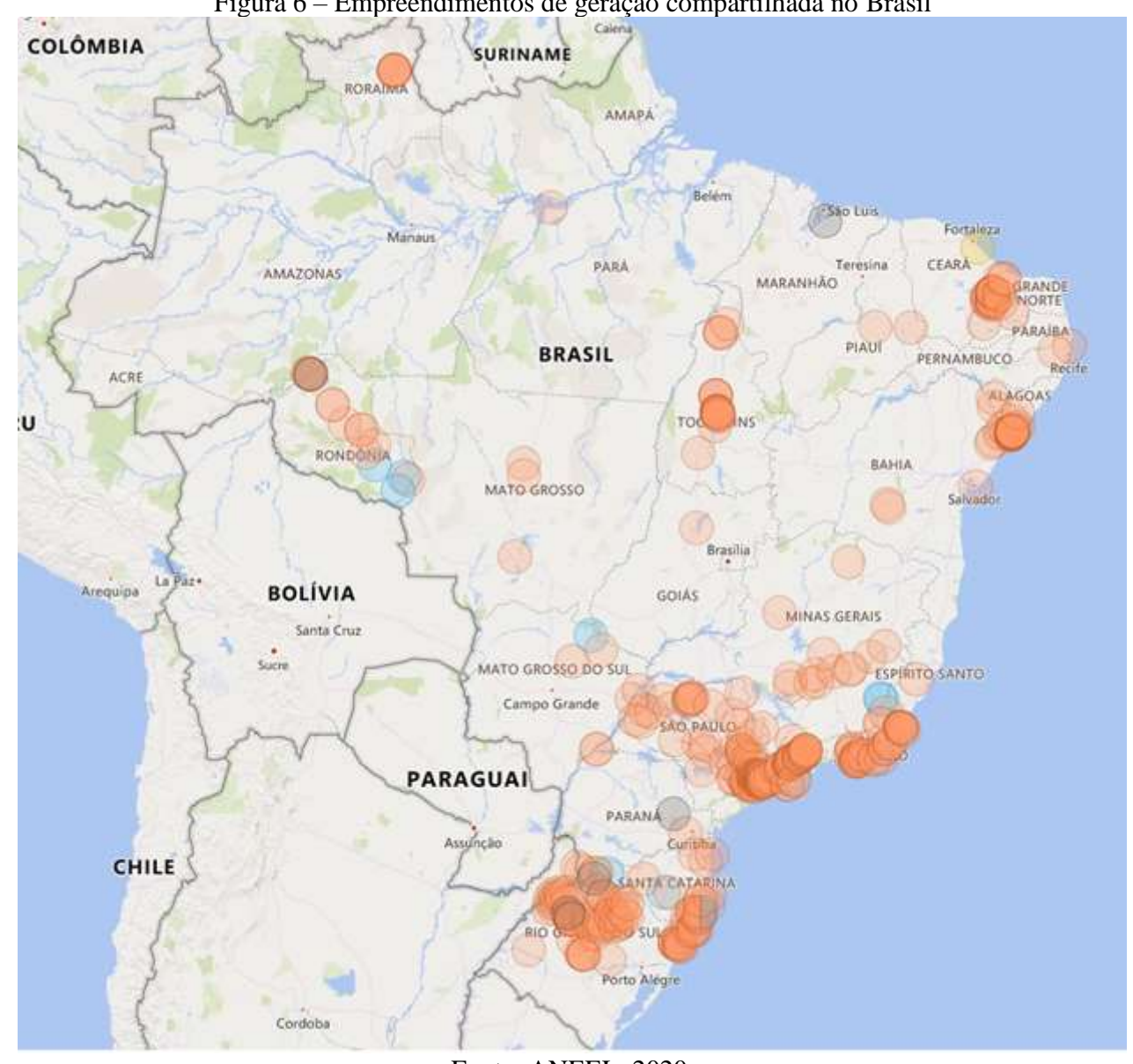

Fonte: ANEEL, 2020. 
Realizando um levantamento da classe de consumo dos empreendimentos de geração compartilhada (Figura 7), observa-se que a classe que mais usufrui dessa modalidade atualmente é a residencial, com 319 empreendimentos, seguida da comercial, com 170, e rural, com 104. Sendo assim, os grupos de tensão que mais utilizam essa modalidade é o B1, B2 e B3 (ANEEL, 2020).

Figura 7 - Geração compartilhada no Brasil por classe de consumo

\section{Geração Compartilhada no Brasil por Classe de Consumo}

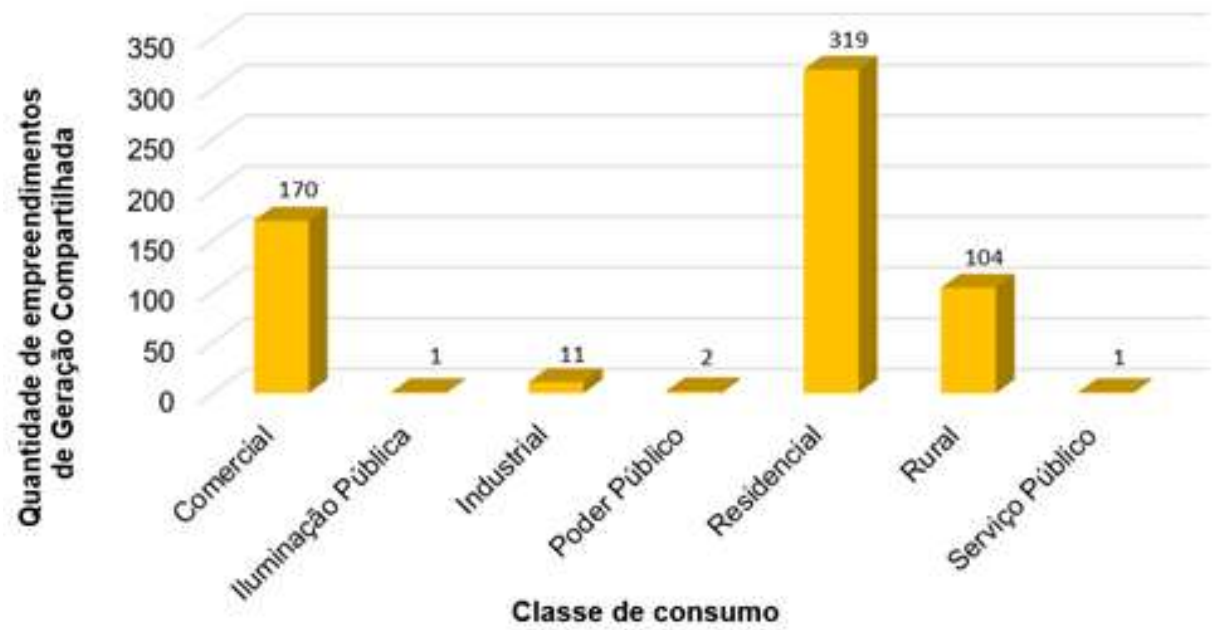

Fonte: Adaptado de ANEEL, 2020.

\section{ESTUDOS DE VIABILIDADE ECONÔMICO-} FINANCEIRA DA GERAÇÃO COMPARTILHADA

Após a publicação da REN 687/2015, alguns autores analisaram a viabilidade econômico-financeira das usinas de geração compartilhada de energia elétrica, seja através de consórcios ou cooperativas. A seguir são descritos alguns desses estudos, os quais comprovam a viabilidade da modalidade de geração compartilhada.

Santos (2019) analisou a redução dos custos de instalação da usina fotovoltaica quando 3 UCs em Minas Gerais a adquirem de forma coletiva através de consórcio, quando comparada a aquisição individual dessas usinas. A partir desse estudo, foi constatada significativa economia no custo de instalação (de até 32\%) para cada uma das UCs. Esses resultados revelam o potencial que existe na formação de consórcios para a obtenção de uma usina de geração compartilhada fotovoltaica.

Outro trabalho realizado por Faria e Spíndola (2018) verificou a viabilidade técnica e econômico-financeira de uma usina fotovoltaica de geração compartilhada como opção para diminuição dos custos com energia elétrica para dez UCs em Goiás. Para isso, foram avaliados os indicadores econômicos de Valor Presente Líquido (VPL), Índice de Lucratividade (IL), Taxa Interna de Retorno (TIR) e payback. Os resultados demonstram que o sistema é viável para os dois cenários avaliados e, portanto, pode atrair participantes com potencial de investidores.

Cousseau (2017) realizou uma pesquisa de implantação, dimensionamento e viabilidade econômica de uma cooperativa solar fotovoltaica para a geração de energia entre 26 cooperados no Rio Grande do Sul. Através de uma análise de investimento do capital ao longo de 20 anos, resultou em um tempo de retorno médio do investimento de 6,5 anos. O tempo de retorno de investimento para cada cooperado individual sofreu variações de acordo com o percentual de geração de energia e capital investido.
No estudo de Campos, Ramos e Azevedo (2016) concluiu-se que a criação de uma cooperativa de consumo de energia elétrica é viável do ponto de vista econômico e regulatório, podendo oferecer uma garantia do suprimento e uma considerável redução do custo de energia elétrica para seus cooperados.

No artigo de Paris Junior e Takigawa (2019) são apresentadas vantagens e desvantagens da implantação de um sistema de GD fotovoltaica na configuração de geração compartilhada, atendendo um grupo de 20 UCs em Santa Catarina. Nesse estudo, é analisado o retorno financeiro por meio das metodologias de VPL, TIR e payback. Como resultado da análise, observa-se que não há grandes mudanças no payback e na TIR entre realizar um investimento inicial ou financiar todo o montante do sistema. Por outro lado, nos cenários que prevê a locação ou o arrendamento do terreno para implantação do sistema fotovoltaico há uma mudança significava, quando comparados com os demais nos quais o terreno é comprado. Nota-se também que a isenção dos impostos (Programa de Integração Social (PIS), Contribuição para Financiamento da Seguridade Social (COFINS) e Imposto sobre Circulação de Mercadorias e Prestação de Serviços (ICMS)) favorece significativamente para a viabilidade econômica do empreendimento. Desse modo, o modelo analisado teve um payback razoável quando comparado com sistemas fotovoltaicos individuais e uma TIR no período de vida útil da planta geradora acima da Taxa Mínima de Atratividade (TMA), o que viabiliza o investimento.

Magalhães (2018) analisa a inserção de uma minigeração solar fotovoltaica em Santa Catarina na modalidade de geração compartilhada, por meio de um consórcio firmado entre 3 UCs do Grupo A. Nessa pesquisa, foram simulados diferentes cenários de investimento. $\mathrm{O}$ cenário pessimista obteve um payback de 15 anos, o cenário realista obteve um payback de 12 anos e o cenário otimista um payback de 9 anos. Além disso, 
constatou-se que a implementação da geração compartilhada fotovoltaica resulta em uma economia de $63 \%$ na fatura das três indústrias modeladas, dentro do período de 25 anos.

Em seu estudo, Almeida (2016) analisa a viabilidade financeira da geração compartilhada para atender a 3 UCs (uma casa e dois apartamentos) em Santa Catarina. Para essa análise econômica, foram realizadas as etapas de dimensionamento, projeto, orçamento e cálculos financeiros. Através dos cálculos, conclui-se que a alternativa é viável e atrativa financeiramente.

Frâncica (2018) apresenta soluções de geração compartilhada na forma de cooperativas para consumidores residenciais do Grupo B1 no Paraná. Esse autor realiza uma análise comparativa de três soluções técnicas para a usina solar fotovoltaica (telhado, solo e estacionamento), bem como apresenta uma solução administrativa e um modelo de negócios para um empreendedor. Uma análise econômica minuciosa é realizada provando a viabilidade financeira do projeto.

Cardoso (2019) avaliou a viabilidade econômica da implantação de uma cooperativa solar fotovoltaica para geração de energia elétrica em Minas Gerais, constituída de 20 cooperados. Nesse estudo, foram levantados os riscos financeiros do negócio, os investimentos necessários, o custo de oportunidade de capital e também foram projetados os fluxos de caixa livres do projeto. As pesquisas realizadas revelam que o projeto, com vida útil de 25 anos, gera valor para os investidores, dado que os retornos superam o custo de oportunidade do capital, independente da estrutura de capital utilizada.

Rosolen (2017) mensura a viabilidade econômica da geração compartilhada em mini usinas fotovoltaicas a serem instaladas em São Paulo. São aplicados os métodos de análise de investimento de Valor Atual Líquido (VAL), TIR, Taxa Interna de Retorno Modificada (TIRM) e payback. Através dessa análise, é evidente que o investimento é mais vantajoso quanto maior for o consumo elétrico do investidor e quanto menor for o retorno financeiro que o investidor espera dos seus investimentos.

\section{CONCLUSÃO}

Através de uma análise legislativa, torna-se possível compreender as diretrizes impostas pela REN 687/2015 e as possibilidades que essa resolução fornece aos consumidores que desejam instalar uma GD, seja junto à carga, em condomínio, com autoconsumo remoto ou com geração compartilhada. No caso específico de geração compartilhada, nota-se que essa modalidade deve ser mais utilizada no Brasil nos próximos anos, devido ao seu alto potencial de aplicação. Por isso, torna-se relevante compreender essa modalidade em seus detalhes e, ainda, comprovar a sua viabilidade econômica.

A análise realizada, no âmbito financeiro, descreve estudos que revelam resultados surpreendentes. Nesses estudos, a viabilidade econômico-financeira da geração compartilhada é comprovada através de cálculos envolvendo indicadores financeiros, tais como o VPL, IL, TIR, payback, entre outros. Verifica-se a redução dos custos de instalação de uma usina quando os consumidores a adquirem de forma coletiva por meio de consórcio/cooperativa, quando comparada a aquisição individual dessas usinas. Nesse contexto, os dados apresentados nesse trabalho auxiliam no sentido de dar mais segurança para o consumidor que deseja investir na modalidade de GD compartilhada.

\section{AGRADECIMENTOS}

Agradecemos a Universidade Tecnológica Federal do Paraná (UTFPR) e ao Instituto Politécnico de Bragança (IPB), pela oportunidade de aprofundar e realizar estudos nesse tema.

\section{REFERÊNCIAS}

AGÊNCIA NACIONAL DE ENERGIA ELÉTRICA ANEEL. Geração Distribuída. Disponível em: <https://app.powerbi.com/view?r=eyJrIjoiZjM4NjM0OWYt N2IwZS00YjViLTllMjItN2E5MzBkN2ZIMzVkIiwidCI6Ij QwZDZmOWI4LWVjYTctNDZhMi05MmQ0LWVhNGU5 YzAxNzBlMSIsImMiOjR9>. Acesso em 09 jul 2020.

AGÊNCIA NACIONAL DE ENERGIA ELÉTRICA ANEEL. Resolução Normativa $n^{\circ}$ 687, de 24 de novembro de 2015. Disponível em: <https://www2.aneel.gov.br/cedoc/ren2015687.pdf>. Acesso em 09 jul 2020.

AGÊNCIA NACIONAL DE ENERGIA ELÉTRICA ANEEL, Micro e minigeração distribuída: sistema de compensação de energia elétrica / Agência Nacional de Energia Elétrica, 2. ed, Brasília, 2016.

ALMEIDA, Augusto Nichele Ottoni de, Projeto e análise de viabilidade econômica de um sistema de geração compartilhada nos padrões da resolução normativa ANEEL $\mathbf{n}^{\circ}$ 687/2015, Universidade Federal de Santa Catarina, Araranguá - Santa Catarina, 2016.

CAMPOS, Fred Leite Siqueira; RAMOS, Fabio do Lago; AZEVEDO, Beatriz Marcondes de, Análise de viabilidade econômica regulatória à criação de cooperativa de consumo de energia elétrica - o caso do setor elétrico brasileiro na segunda década do século XXI, Revista Produção Online, Florianópolis, SC, v. 16, n. 3, p. 966-987, jul./set. 2016.

CARDOSO, Diego Silva, Geração Compartilhada de Energia Fotovoltaica na Região Centro-Oeste de Minas Gerais: análise de viabilidade econômico-financeira e de criação de valor aos investidores cooperados, Fundação Pedro Leopoldo, Pedro Leopoldo, 2019.

COUSSEAU, Fernando, Estudo de Viabilidade para Proposição de uma Cooperativa Solar Fotovoltaica para Serra Nordeste do Rio Grande do Sul, Panambi, 2017.

FARIA, Vitor Rezende; SPÍNDOLA, Guilherme Morais, Análise Econômica-Financeira da Instalação de um Sistema de Energia Solar Fotovoltaica na Modalidade Geração Compartilhada em Goiás, VI Escola Regional de Informática de Goiás, Goiânia, 2018.

FRÂNCICA, André Luís Caneparo, Cooperativa de energia solar: proposta de modelo para consumidores residenciais, Universidade Federal do Paraná, Curitiba Paraná, 2018.

GREENER, Como Estruturar um Consórcio ou Cooperativa? Entendendo como Funciona a Geração Compartilhada, 2017. Disponível em: <https://greener.com.br/wp-content/uploads/2017/04/ebookcooperativaeconsorcio.pdf $>$. Acesso em 20 mar 2020. 
LIMA, Danilo de Brito, Cooperativas de energia: guia de constituição de cooperativas de geração distribuída fotovoltaica, Sistema OCB, Cooperação Alemã, Giz, DGRV, 2018.

MAGALHÃES, Flávia de Souza, Análise da minigeração fotovoltaica distribuída sob o enfoque da modalidade de geração compartilhada por meio de consórcio, Instituto Federal de Educação, Ciência e Tecnologia de Santa Catarina, Florianópolis, 2018.

PARIS JUNIOR, Wanderley; TAKIGAWA, Fabrício Y. K.; NETO, Edison A. C. Aranha, FERNANDES, Rubipiara C., Levantamento da Geração Distribuída Compartilhada no Brasil, VII Congresso Brasileiro de Energia Solar, Gramado, 2018.

PARIS JUNIOR, Wanderley; TAKIGAWA, Fabrício Y. K., Análise das vantagens e desvantagens da geração compartilhada pela ótica do consumidor e do gerador, XVIII ERIAC, Décimo Oitavo Encontro Regional IberoAmericano do CIGRE, Foz do Iguaçu - Paraná, 2019.

ROSOLEN, Rafael Augusto de Godoy. Análise da Viabilidade Econômica para a Geração Compartilhada em Mini Usinas Fotovoltaicas, Universidade de São Paulo, São Carlos, 2017.

SANTOS, Filipe Peixoto, Análise da instalação de usinas de geração distribuída fotovoltaica comunitária por meio da formação de consórcio, Universidade Federal de Viçosa, Viçosa - Minas Gerais, 2019.

\section{COPYRIGHT}

Direitos autorais: Os autores são os únicos responsáveis pelo material incluído no artigo. 


\title{
Revista SODEBRAS - Volume 15 \\ $\mathrm{N}^{\circ} 178$ - OUTUBRO/ 2020
}

\section{MODELAGEM E SIMULAÇÃO DE UM BANCO DE ESTOCAGEM EM BATERIAS COM GERADOR FOTOVOLTAICO}

\author{
MODELING AND SIMULATION OF A STOCK BANK IN BATTERIES WITH \\ PHOTOVOLTAIC GENERATOR
}

\author{
MÁRCIO AUGUSTO TELES DA CRUZ1; JOÃO BATISTA DIAS ${ }^{2}$ \\ 1; 2 - LABORATÓRIO DE ENERGIA SOLAR FOTOVOLTAICA - UNIVERSIDADE DO \\ VALE DO RIO DOS SINOS \\ emailprofissional.mcruz@gmail.com; joaobd@unisinos.br
}

\begin{abstract}
Resumo - Este trabalho aborda o dimensionamento e simulação de um banco de estocagem em baterias com gerador fotovoltaico para alimentação de um dispositivo de monitoramento remoto. A tensão de alimentação do dispositivo deve permanecer na condiçãa de operação do instrumento, independentemente das variações climáticas locais. Logo, seu dimensionamento adequado é fundamental para sua operação confiável. Através de uma simulação dinâmica, desenvolvida no Simulink e, utilizando modelo de bateria proposto por Tremblay e Dessaint (2009), foi possível prever o comportamento do banco de estocagem para a condição de descarga e avaliar seu comportamento para as condições de alta ou baixa irradiância. Com a montagem experimental do sistema fotovoltaico $e$ do dispositivo de monitoramento remoto, foi possível obter dados reais de campo, a fim de comprovar o atendimento a autonomia desejada.
\end{abstract}

Palavras-chave: Simulação. Banco de Estocagem em Baterias. PV System.

\begin{abstract}
This work addresses the dimensioning and simulation of a battery storage bank with photovoltaic system to supply a remote monitoring device. The supply voltage of the device must remain in the operating condition of the instrument, regardless of local climatic variations. Therefore, its adequate sizing is fundamental for its reliable operation. Through a dynamic simulation, developed in Simulink and, using the battery model proposed by Tremblay and Dessaint (2009), it was possible to predict the behavior of the storage for the discharge condition and to evaluate its behavior for the conditions of high or low irradiance. With the experimental setup of the photovoltaic system and remote monitoring device, it was possible to obtain real field data in order to prove compliance with the desired autonomy.
\end{abstract}

Keywords: Simulation. Battery Storage Bank. PV System.

\section{INTRODUÇÃO}

O sistema fotovoltaico isolado (SFI), ou off-grid, comumente empregado em equipamentos remotos, visa atender a uma demanda específica de energia. Seu dimensionamento passa por várias etapas sendo, uma delas o dimensionamento de um banco de estocagem (BE) (CRESESB, 2014).

Segundo pesquisa de Neto, Lotufo e Santos (2016), cada tecnologia de estocagem de energia apresenta particularidades as quais devem ser atendidas. Dentre estas tecnologias destacam-se as baterias de chumbo ácido.
Estas possuem a característica de armazenamento simples, são facilmente encontradas no mercado e, apresentam grande variedade de modelos disponíveis de baixo custo. São altamente empregadas para o propósito da estocagem de energia. Destacam-se também por apresentarem a característica reciclável e bom tempo de vida útil. A bateria de chumbo ácido é considerada a escolha mais econômica para a aplicação em sistemas de armazenamento de pequeno porte (alguns W a kWh) e grande porte (a partir de 100 $\mathrm{kWh}$ ) em áreas isoladas (FERREIRA, 2015).

Porém, apresentam algumas limitações referentes às rigorosas aplicações. Como os acumuladores chumbo ácido necessitam de manutenção frequente, aplicação de água, as baterias reguladas por válvulas (VRLA) são livres dela. Entretanto, os custos da VRLA são mais elevados devido às tecnologias empregadas. A particularidade deste elemento está no uso de uma válvula a qual se abrirá quando os gases formados em seu interior atingirem um patamar perigoso, acionando uma válvula para eliminá-los (CARNEIRO et al.,2017).

Existem parâmetros que definem e classificam uma bateria, sendo eles a capacidade nominal $(\mathrm{Cx})$, para uma taxa de descarga (x horas), a taxa de carga e descarga e o estado de carga (SOC). A capacidade nominal corresponde a carga total que pode ser armazenada. Estes valores, definidos pelos fabricantes podem ser, como exemplo, nos tempos de $5 \mathrm{~h}, 10 \mathrm{~h}$ e $100 \mathrm{~h}$, correspondentes a C5, C10 e $\mathrm{C} 100$, respectivamente, em (Ah). A taxa de descarga, corresponde ao tempo necessário para que a bateria descarregue através de uma corrente constante (-Ibat). Já a taxa de carga corresponde a aplicação e uma corrente constante (+Ibat), aplicada para a bateria atingir seu estado de carga. O estado de carga da bateria (SOC) está relacionado com a carga elétrica armazenada na bateria por um dado tempo, sendo $\mathrm{SOC}=0$, bateria descarregada e $\mathrm{SOC}=1$, bateria completamente carregada. Existe um complemento à unidade SOC a qual é dada pela profundidade de descarga $\mathrm{Pd}=1$-SOC e representa a fração de descarga da bateria (FRAGA, 2009).

A deficiência de recarregamento das baterias de um SFI, durante os períodos de dias encobertos, baixa irradiância, contribui para a redução da vida útil dos seus elementos (células), ocorrendo com maior frequência nas baterias do tipo chumbo-ácido (CRESESB, 2014). 
Analisar o comportamento de uma bateria nas situações envolvendo a carga e a descarga, variáveis no tempo, permite predizer seu comportamento. Existe um modelo de bateria, prático e de fácil implementação o qual permite reproduzir a dinâmica da carga e a descarga. Com a extração de dados da curva de descarga de uma bateria do tipo chumbo-ácido, dados do fabricante e, implementando o modelo em uma simulação, é possível prever a sua resposta ao longo do tempo com base em seu estado de carga (TREMBLAY, DESSAINT, 2009).

O objetivo deste artigo é apresentar os resultados de um dimensionamento e simulação de um banco de estocagem (BE), com dados de radiação para o plano inclinado e dispositivos de geração, operação e proteção, previamente dimensionados (módulo fotovoltaico, carregador e disjuntor), de forma a suprir, eletricamente, um dispositivo de monitoramento remoto (DMR), instalado em um sistema de mitigação de interferência elétrica de dutos metálicos enterrados.

\section{METODOLOGIA}

Para efetuar a carga do BE utilizou-se 2 módulos fotovoltaicos monocristalino, sendo suas especificações individuais de: 36 células, $50 \mathrm{~W}_{\mathrm{p}}, \mathrm{V}_{\mathrm{oc}}$ de $21,6 \mathrm{~V}, \mathrm{I}_{\mathrm{sc}}$ de 3,03 A e, eficiência de conversão de 10,5\%. Para o controle de carga e descarga do BE empregou-se um controlador da marca Epever, modelo LS2024B, com limite de corrente de 20 A e uma tensão superior a $40 \%$ de $\mathrm{V}_{\mathrm{oc}}$, na temperatura mínima.

A carga considerada a ser suprida eletricamente é composta por 3 transdutores e um dispositivo denominado de remota (modem GPRS), totalizando uma potência instalada de $8,64 \mathrm{~W}$, chamada de $P_{L}$, já considerado um fator de segurança de $20 \%$.

A remota possui uma tensão máxima de operação de $15,4 \mathrm{~V}$ e mínima de $11,8 \mathrm{~V}$, enquanto os transdutores possuem uma tensão máxima de operação de $13,7 \mathrm{~V}$ e mínima de $11,8 \mathrm{~V}$.

\section{1 - Dimensionamento do BE}

$\mathrm{O}$ banco de estocagem (BE) tem o objetivo de atender a demanda quando ocorrer baixa ou a falta completa de radiação solar. Um dado que está relacionado com a vida útil do $\mathrm{BE}$ é a profundidade de descarga $\left(\mathrm{P}_{\mathrm{d}}\right)$ (FRAGA, 2009). Valores comumente empregados em ciclos de descarga rasos são de $20 \%$ a $40 \%$ e, para ciclos profundos são de $50 \%$ a $80 \%$ (CRESESB, 2014). A capacidade nominal do banco de estocagem $(\mathrm{Cx})$, a qual corresponde ao total de carga que deve ser armazenada, é definida pela Equação (1). Este valor, no entanto, é dependente de $\left(\mathrm{P}_{\mathrm{d}}\right)$ (considerado no dimensionamento, 50\%) e a eficiência da capacidade da bateria (adotado no dimensionamento, 90\%) (SAMOUDI, 2015).

$$
C A h=\left(\epsilon_{c} /\left(V_{\text {nom }} \eta_{\text {bateria }} P_{d}\right)\right) N
$$

onde $N$ representa a autonomia do BE. Logo, a bateria selecionada para compor o banco de estocagem foi a de chumbo-ácido, da marca Global, selada e regulada a válvula (VRLA) de tensão nominal $V_{\text {nom }}$ de $12 \mathrm{~V}$, capacidade em $\mathrm{C}_{20}$ de $15 \mathrm{Ah}$. A tensão de flutuação, conforme dados do fabricante é de 13,6 a 13,8 V, cíclico de 14,6 a $15 \mathrm{~V}$ e corrente inicial máxima de 4,5 A. Segundo Ferreira (2015), o acréscimo de baterias em paralelo ocasiona o aumento do armazenamento de energia, proporcionando maior capacidade nominal $C A h$, sem prejuízo a tensão, pois permanece constante.

Em referência ao valor de $N$ da Equação (1) é destacado pelo Cresesb (2014) que pode ser adotado para o Brasil o equivalente entre 2 a 4 dias ( 48 a 96 h).

$\mathrm{O}$ consumo de energia, conforme Melo et al.(2018) e Rampinelli (2010), é definido pela Equação (2), enquanto o número de baterias $\left(N_{b a t}\right)$ em paralelo para compor o $\mathrm{BE}$ define-se pela aplicação da Equação (3), ambas adaptadas, onde $C_{20}$, corresponde a capacidade unitária da bateria e $\epsilon_{c}$ representa o consumo de energia da carga (DMR).

$$
\begin{aligned}
& \epsilon_{c}=24 P_{L} \\
& N_{b a t}=C_{A h} / C_{20}
\end{aligned}
$$

\section{1 - Modelagem}

No ambiente Simulink foram efetuadas as simulações dinâmicas em modelos desenvolvidos especialmente para prever o comportamento do BE, nas situações de descarga e para carga e descarga nos períodos de alta e baixa radiação. Fraga (2009), aplicou esta metodologia em seu trabalho, porém utilizou somente o ambiente Matlab, através de uma equação matemática, a qual representa o modelo de uma bateria de chumbo-ácido para prever o comportamento de um BE. Carvalho (2013), menciona que o Simulink permite a construção de modelos de subsistemas, agregando-os até à obtenção do modelo desejado, e dispõe de componentes os quais necessitam de pequenas modificações para representar inúmeros modelos desejados. Para o modelo, desenvolvido no Simulink, foi empregado uma bateria de chumbo-ácido, disponível na biblioteca do programa, que permite modelar o comportamento de uma bateria configurando-a com parâmetros extraídos da folha de dados do fabricante, curva de descarga à corrente constante. Com a extração dos dados de tensão totalmente carregada $\left(\mathrm{V}_{\text {full }}\right)$, final da zona exponencial $\left(\mathrm{Q}_{\exp }, \mathrm{V}_{\exp }\right)$, final da zona nominal $\left(\mathrm{Q}_{\text {nom }}, \mathrm{V}_{\text {nom }}\right)$ ponto onde a tensão começa a cair abruptamente, capacidade máxima $(\mathrm{Q})$ e resistência interna $(\mathrm{R})$, foi possível simular o comportamento de uma bateria do tipo chumbo-ácido. Esta metodologia, melhorada por Tremblay e Dessaint, (2009), com base no modelo de Shepherd (1965 apud TREMBLAY; DESSAINT, 2009), foi aplicada em outros trabalhos como o de Carvalho (2013), Ferreira (2015) e Pereira (2016). A validação do modelo de bateria ocorre mediante a reprodução da curva característica de descarga, em corrente constante, típica da bateria (TREMBLAY; DESSAINT, 2009).

Os dados para a reprodução da curva de descarga da bateria, marca Global, foram extraídos através de uma bancada de ensaio e aplicados, posteriormente, ao modelo implementado via Simulink, Figura 2. Ferreira (2015) aplicou este ensaio o qual utilizou um reostato (carga variável) para manter a corrente constante no processo de descarga de uma bateria do tipo chumbo ácido, a fim de obter os parâmetros dela. Desta forma, foi montado um circuito de descarga a corrente constante 3 A e temperatura ambiente de $25^{\circ} \mathrm{C}$, assumindo como temperatura de descarga. O circuito montado o qual proporcionou a obtenção da curva de descarga desta bateria está representado na Figura 1. 


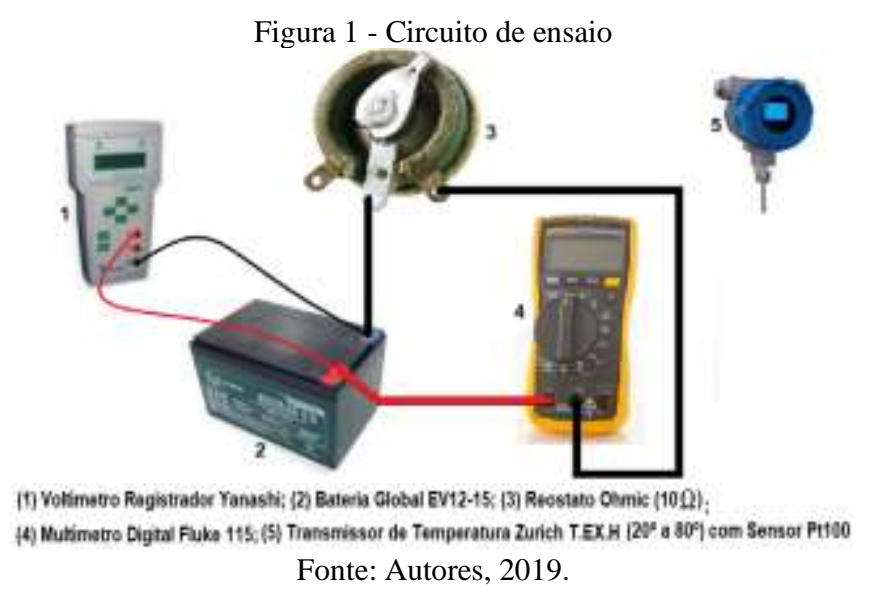

A partir do carregamento total da bateria, via controlador de carga Epever, modelo LS2024B, foi efetuada a sua descarga, mantendo o reostato no ajuste necessário, variando-o para manter a corrente de descarga constante, visualizada no amperímetro $(3 \mathrm{~A})$, durante todo o processo. $O$ registrador teve a função de gravar os valores de tensão a cada segundo. Com a interpretação da curva de descarga, foram obtidos os parâmetros necessários para serem inseridos no modelo unitário de bateria, circuito demonstrado na Figura 2.

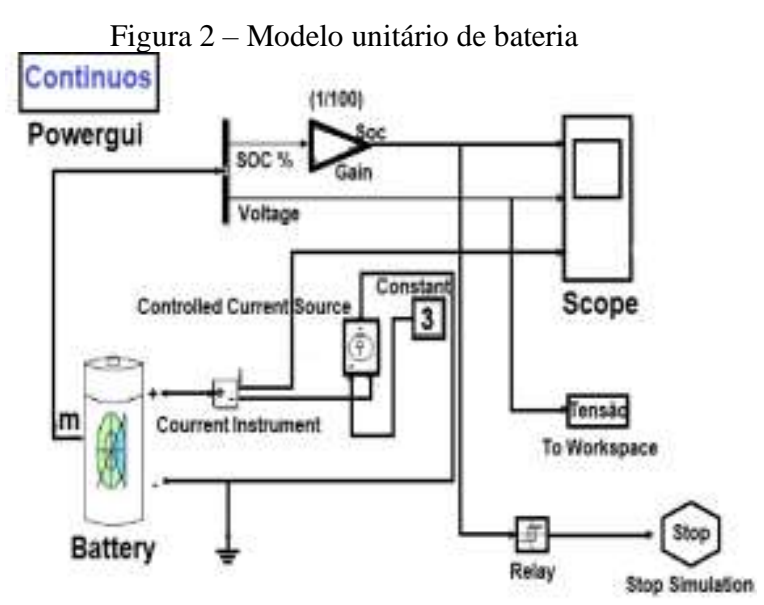

Fonte: Autores, 2019.

O gráfico de comparação, curva de ensaio versus curva de simulação do modelo unitário de bateria, é demostrado na Figura 3.

Figura 3 - Ensaio de descarga versus modelo unitário

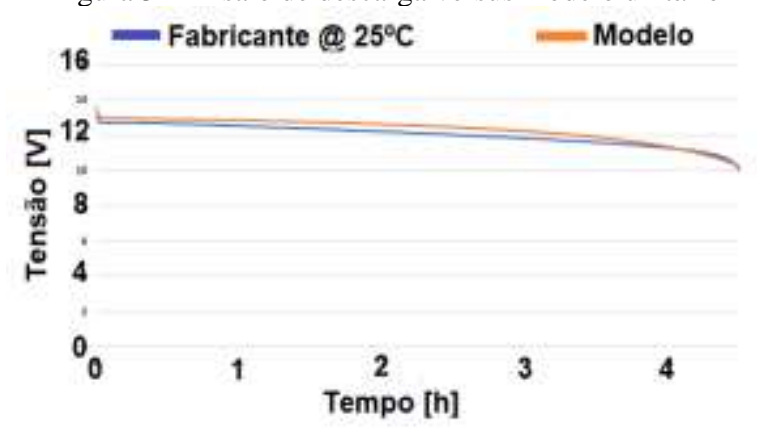

Vfull=13,72 V; Qexp=0,1 Ah; Vexp=13,1 V; Qnom=10 Ah; Vnom=12 V Fonte: Autores, 2019.

O comportamento do modelo apresenta similaridade ao da curva de ensaio, até a tensão de $10,5 \mathrm{~V}$, apresentando desvio percentual médio calculado de $2,46 \%$, sendo, desta forma, validado para as próximas simulações.

Como forma de simular o BE, composto por 8 baterias de chumbo-ácido, quantidade resultante da equação (3), implementou-se um circuito lógico, semelhante aos trabalhos de Carvalho (2013), Ferreira (2015) e Pereira (2016). O circuito implementado possui 8 modelos de bateria, próprios do programa Simulink, composto por uma função, Matlab Function, o qual permite programar a execução de códigos específicos, um resistor para representar o DMR (carga), uma fonte de corrente controlada, dependente da Equação (4), para efetuar a carga das baterias, chaves Switch controladas por uma lógica dedicada, permitindo o controle de carga e descarga do BE e, um bloco de equações o qual representa a corrente gerada pelo módulo fotovoltaico, definida pela Equação (4). Neste último bloco, a corrente $I_{s c}$ de entrada varia em função da irradiância e da temperatura, sendo estas, geradas por blocos de sinais, ligados diretamente na entrada do bloco de equações, metodologia semelhante aos modelos de Carvalho (2013). Com isso, o modelo montado, conforme Figura 4 é capaz de reproduzir o comportamento dos processos de carga e descarga do $\mathrm{BE}$, tendo como referência os parâmetros da bateria definidos no ensaio e validados através do modelo unitário.

$$
I_{S C}=\left(G / G_{S T C}\right)\left[I_{S C O}+k_{c i}\left(T_{m o d}-T_{r e f}\right)\right]
$$

onde $k_{c i}\left(0,1 \times 10^{-3} /{ }^{\circ} \mathrm{C}\right)$, dado do fabricante, representa o coeficiente de variação de $I_{S C}$, em função da temperatura da célula. (CRESESB, 2014).

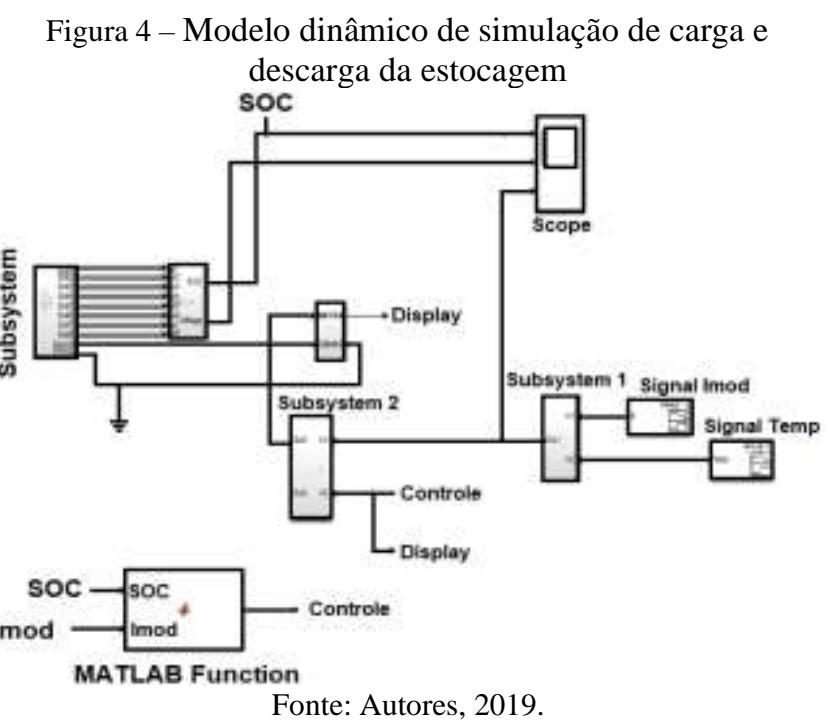

\section{RESULTADOS}

Nesta etapa foram efetuadas as simulações sobre o modelo da Figura 4 para avaliar tanto o atendimento a autonomia projetada (3 dias) quanto seu comportamento nas situações de descarga e carga, diante as variações de irradiância. Aplicou-se também um ensaio de campo, a fim de avaliar o comportamento do banco de estocagem de forma real nas situações de descarga.

\section{1 - Resultados da Simulação}

Com o objetivo de avaliar o atendimento a autonomia projetada, efetuou-se a simulação de descarga, partindo da 
premissa que o BE esteja com $\mathrm{SOC} i=100 \%$ e sem o aporte de energia solar do gerador fotovoltaico. Nesta condição, somente o resistor de $32 \Omega$ (equivalente a carga do DMR), consome a energia do $\mathrm{BE}$, até atingir o estado de carga equivalente a $\mathrm{SOCf}=30 \%$. O mesmo processo foi aplicado para a condição inicial de $\mathrm{SOC}$ i à $80 \%$ e SOCi à $60 \%$. Os resultados da simulação, obtidos via Simulink são mostrados nas Figuras 5, 6 e 7 e, correspondem a $\mathrm{SOC}_{\mathrm{i}}=100 \%, \mathrm{SOC}_{\mathrm{i}}$ $=80 \%$ e, $\mathrm{SOC}_{\mathrm{i}}=60 \%$, respectivamente.

Figura 5 - Simulação de descarga com $\mathrm{SOC}_{\mathrm{i}}=100 \%$

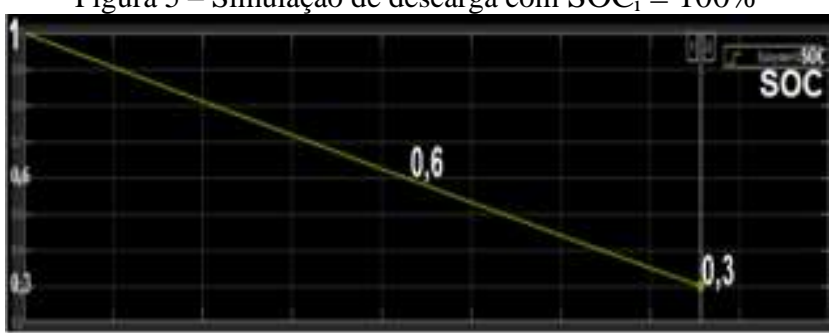

Fonte: Autores, 2019.

Figura 6 - Simulação de descarga com $\mathrm{SOC}_{\mathrm{i}}=80 \%$

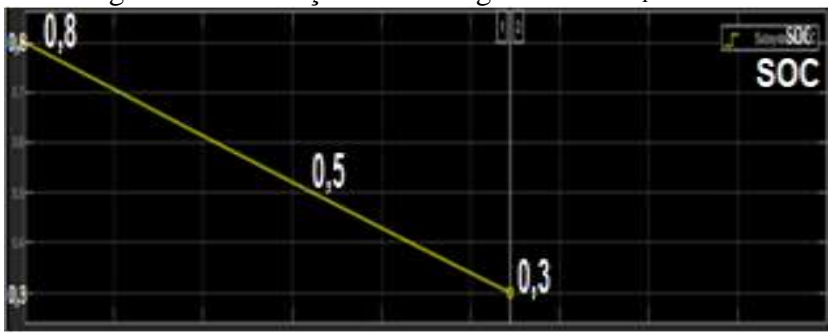

Fonte: Autores, 2019.

Figura 7 - Simulação de descarga com $\mathrm{SOC}_{\mathrm{i}}=60 \%$

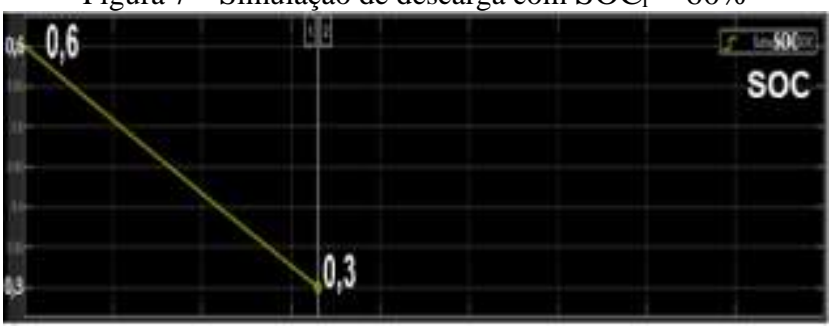

Fonte: Autores, 2019.

Na Tabela 1, interpretação dos resultados, o BE pode atender a demanda da carga por aproximadamente 9 dias, considerando a condição de $\mathrm{SOC}_{\mathrm{i}}=100 \%$. Na condição de $\mathrm{SOC}_{\mathrm{i}}=80 \%$, o BE é capaz fornecer energia por 6 dias. Já para a condição $\mathrm{SOC}_{\mathrm{i}}=60 \%, \mathrm{o} \mathrm{BE}$ atende à demanda de carga por aproximadamente 4 dias. Ambos os casos sem nenhuma contribuição de irradiância. Em nenhuma das situações de descarga a tensão do BE atingiu o nível crítico, ou seja, a tensão mínima de operação do DMR.

Tabela 1 - Interpretação da simulação de descarga

\begin{tabular}{ccc}
\hline CARGA & Tensão $(\mathbf{V})$ & Autonomia (Dia) \\
\hline $\mathrm{SOC}_{\mathrm{i}}=100 \%$ & $\mathrm{~V}_{\mathrm{i}}=13,76$ & --- \\
$\mathrm{SOC}_{\mathrm{f}}=30 \%$ & $\mathrm{~V}_{\mathrm{f}}=12,18$ & 8,75 \\
\hline $\mathrm{SOC}_{\mathrm{i}}=80 \%$ & $\mathrm{~V}_{\mathrm{i}}=12,99$ & --- \\
$\mathrm{SOC}_{\mathrm{f}}=30 \%$ & $\mathrm{Vf}=12,18$ & 6,3 \\
\hline $\mathrm{SOC}_{\mathrm{i}}=60 \%$ & $\mathrm{~V}_{\mathrm{i}}=12,81$ & --- \\
$\mathrm{SOC}_{\mathrm{f}}=30 \%$ & $\mathrm{~V}_{\mathrm{f}}=12,18$ & 3,83 \\
\hline
\end{tabular}

Fonte: Autores, 2019.
Para a simulação de carga, considerou-se 2 cenários. Cenário 1 , condição de baixa irradiância, com o banco de estocagem parcialmente carregado, com $\mathrm{SOC}_{\mathrm{i}}=30 \%, \mathrm{SOC}_{\mathrm{i}}$ $=50 \%$ e $\mathrm{SOC}_{\mathrm{i}}=80 \%$, permitindo avaliar o tempo necessário para o banco de baterias atingir o estado de carga total, neste caso, com a aplicação de dados de irradiância e temperatura reais, obtidos da estação meteorológica instalada na Universidade do Vale do Rio dos Sinos Unisinos. Estes dados são aplicados na entrada do bloco de equações do modelo, Figura 4. Os resultados da simulação, obtidos via Simulink são mostrados nas Figuras 8, 9 e 10 e, correspondem a $\mathrm{SOC}_{\mathrm{i}}=30 \%, \mathrm{SOC}_{\mathrm{i}}=50 \%$ e, $\mathrm{SOC}_{\mathrm{i}}=80 \%$, respectivamente.

Figura 8 - Simulação de carga com $\mathrm{SOC}_{\mathrm{i}}=30 \%$

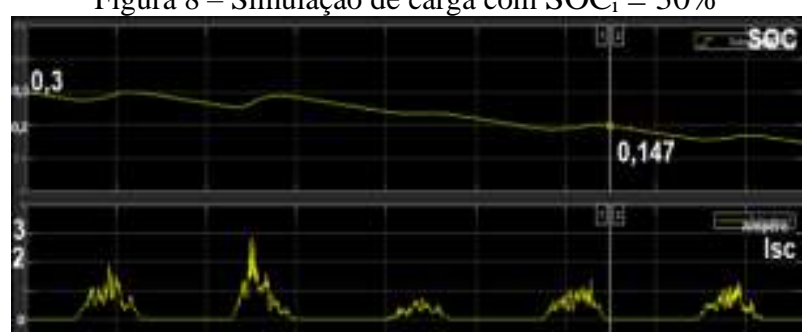

Fonte: Autores, 2019.

Figura 9 - Simulação de carga com $\mathrm{SOC}_{\mathrm{i}}=50 \%$

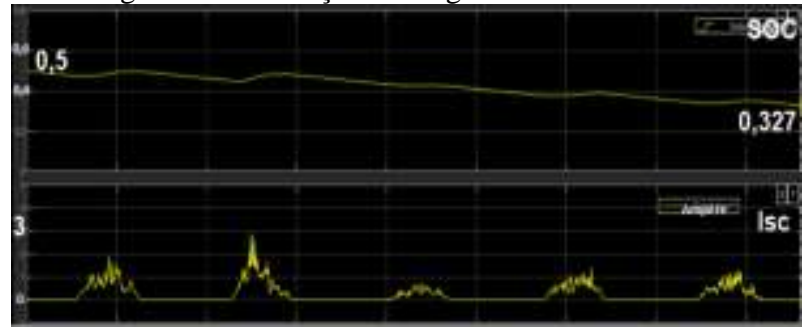

Fonte: Autores, 2019.

Figura $10-$ Simulação de carga com $\mathrm{SOC}_{\mathrm{i}}=80 \%$

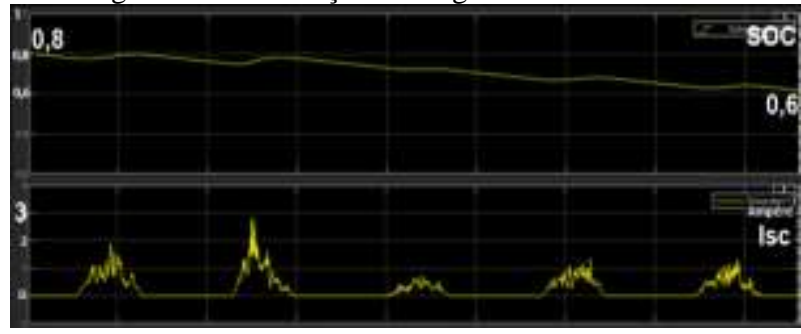

Fonte: Autores, 2019.

A Tabela 2 apresenta a interpretação dos resultados da simulação de carga com $\mathrm{SOC}_{\mathrm{i}}=30 \%, \mathrm{SOC}_{\mathrm{i}}=50 \%$ e $\mathrm{SOC}_{\mathrm{i}}=$ $80 \%$.

Tabela 2 - Interpretação da simulação de carga

\begin{tabular}{lcc}
\hline \multicolumn{1}{c}{ CARGA } & Tensão $(\mathbf{V})$ & Autonomia (Dia) \\
\hline $\mathrm{SOC}_{\mathrm{i}}=30 \%$ & $\mathrm{~V}_{\mathrm{i}}=12,83$ & --- \\
$\mathrm{SOC}_{\mathrm{f}}=14,75 \%$ & $\mathrm{~V}_{\mathrm{f}}=11,30$ & 3,75 \\
\hline $\mathrm{SOC}_{\mathrm{i}}=50 \%$ & $\mathrm{~V}_{\mathrm{i}}=12,66$ & --- \\
$\mathrm{SOC}_{\mathrm{f}}=32,70 \%$ & $\mathrm{Vf}=12,27$ & 5,0 \\
\hline $\mathrm{SOC}_{\mathrm{i}}=80 \%$ & $\mathrm{~V}_{\mathrm{i}}=13,66$ & --- \\
$\mathrm{SOC}_{\mathrm{f}}=60 \%$ & $\mathrm{~V}_{\mathrm{f}}=12,82$ & 5,0 \\
\hline
\end{tabular}

Fonte: Autores, 2019. 
Conforme Tabela 2, considerando o $\mathrm{BE}$ com $\mathrm{SOC}_{\mathrm{i}}=$ $30 \%$ e, na condição de baixa irradiância, o SFI manterá o DMR operando por quase 4 dias, visto que, ao atingir este tempo, terá a tensão crítica de operação do DMR. Logo, nesta condição, o DMR deixará de operar. Considerando o $\mathrm{BE}$ com $\mathrm{SOC}_{\mathrm{i}}=50 \%$ e, na condição de baixa irradiância, o SFI manterá o DMR operando por, pelo menos, 5 dias, visto que até o tempo final de simulação (considerado até 5 dias), a tensão de operação do DMR ficou acima da tensão crítica. Com o BE a SOC $\mathrm{i}=80 \%$ na condição de baixa irradiância, o SFI manterá o DMR operando por mais de 5 dias (final da simulação) e a tensão dos instrumentos acima da tensão crítica. Em ambas as situações simuladas, a carga do BE tenderá para a descarga completa, caso não ocorram as condições de alta irradiância. Em nenhuma das simulações o $\mathrm{BE}$ atingiu a condição de carga máxima $\left(\mathrm{SOC}_{\mathrm{f}}=100 \%\right)$.

Para o cenário 2, considerou-se a condição de alta irradiância, com a estocagem parcialmente carregada, com $\mathrm{SOC}_{\mathrm{i}}=30 \%, \mathrm{SOC}_{\mathrm{i}}=50 \%$ e $\mathrm{SOC}_{\mathrm{i}}=80 \%$, respectivamente. Desta forma, permitiu-se avaliar o tempo necessário para o $\mathrm{BE}$ atingir o estado de carga total, também com a aplicação de dados de irradiância e temperatura reais, da estação meteorológica instalada na Universidade do Vale do Rio dos Sinos - Unisinos. Os resultados desta simulação, obtidos via Simulink são mostrados nas Figuras 11, 12 e 13.

Figura $11-$ Simulação de carga com $\mathrm{SOC}_{\mathrm{i}}=30 \%$

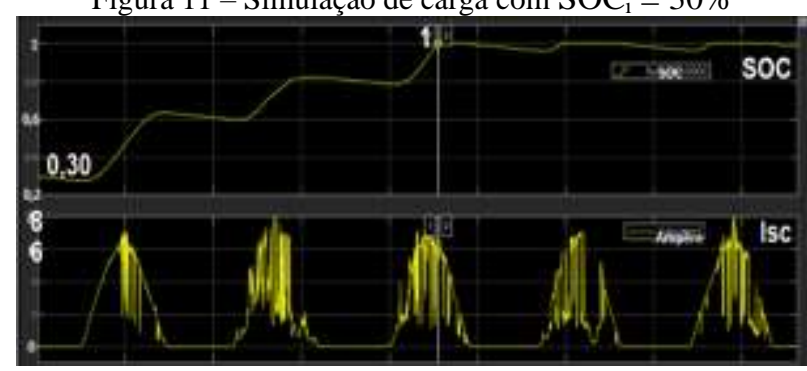

Fonte: Autores, 2019.

Figura $12-$ Simulação de carga com $\mathrm{SOC}_{\mathrm{i}}=50 \%$

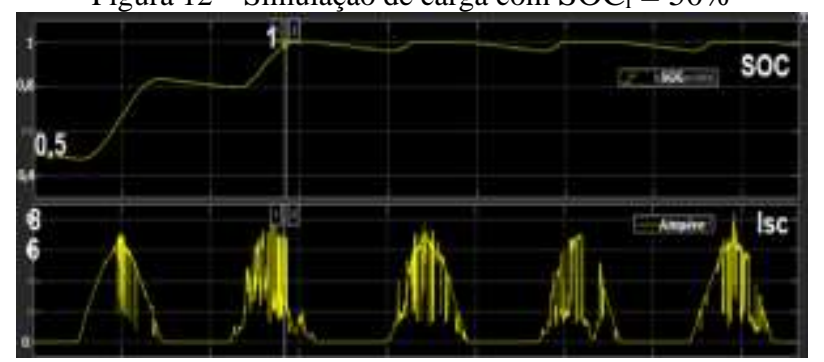

Fonte: Autores, 2019.

Figura 13 - Simulação de carga com $\mathrm{SOC}_{\mathrm{i}}=80 \%$

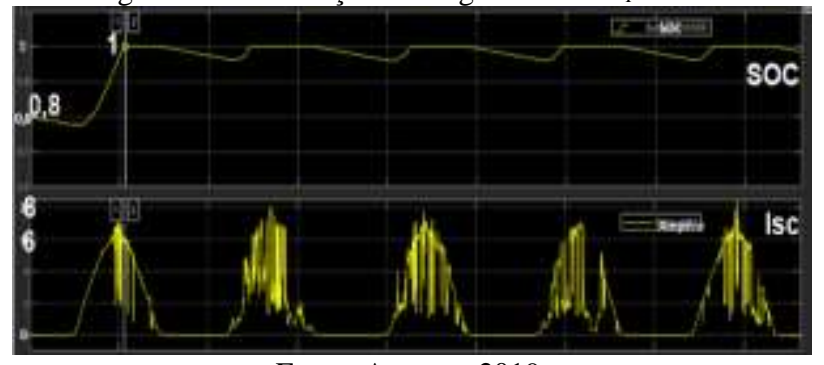

Fonte: Autores, 2019.

A Tabela 3 apresenta a interpretação dos resultados da simulação de carga com $\mathrm{SOC}_{\mathrm{i}}=30 \%, \mathrm{SOC}_{\mathrm{i}}=50 \%$ e $\mathrm{SOC}_{\mathrm{i}}=$ $80 \%$.

Volume 15 - n. 178 - Outubro/2020
Tabela 3 - Interpretação da simulação de carga

\begin{tabular}{lcc}
\hline \multicolumn{1}{c}{ CARGA } & Tensão (V) & Autonomia (Dia) \\
\hline $\mathrm{SOC}_{\mathrm{i}}=30 \%$ & $\mathrm{~V}_{\mathrm{i}}=12,18$ & --- \\
$\mathrm{SOC}_{\mathrm{f}}=100 \%$ & $\mathrm{~V}_{\mathrm{f}}=14,00$ & Plena \\
\hline $\mathrm{SOC}_{\mathrm{i}}=50 \%$ & $\mathrm{~V}_{\mathrm{i}}=12,63$ & --- \\
$\mathrm{SOC}_{\mathrm{f}}=100 \%$ & $\mathrm{Vf}=14,00$ & Plena \\
\hline $\mathrm{SOC}_{\mathrm{i}}=80 \%$ & $\mathrm{~V}_{\mathrm{i}}=13,11$ & --- \\
$\mathrm{SOC}_{\mathrm{f}}=100 \%$ & $\mathrm{~V}_{\mathrm{f}}=14,00$ & Plena \\
\hline \multicolumn{3}{c}{ Fonte: Autores, 2019. }
\end{tabular}

Conforme a Tabela 3, as simulações de carga, para a condição de alta irradiância, proporcionaram o rápido carregamento do BE. Com $\mathrm{SOC}_{\mathrm{i}}=30 \%$, o BE necessitou de 2,63 dias para atingir o estado de carga máximo. Para $\mathrm{SOC}_{\mathrm{i}}$ $=50 \%$, o BE atingiu o estado de carga máximo em 1,64 dias enquanto para $\mathrm{SOC}_{\mathrm{i}}=80 \%$, o BE atingiu o estado de carga máximo em 14,75 horas. Em nenhuma das condições a tensão do DMR atingiu a tensão crítica de operação. Para ambas as situações da Tabela 3, a autonomia foi considerada plenamente atendida.

\section{2 - Resultados dos Ensaios em Campo}

Avaliou-se de forma prática o comportamento do BE durante o período de janeiro a julho de 2019. Neste período foi possível, tanto remotamente como através de data logger local, obter o histórico dos dados de campo para as condições de carga e descarga. Ambas as avaliações destas condições foram executadas com o DMR conectado. A Figura 14 mostra os resultados para a condição sem irradiância (SFI desligado), com as curvas de descarga, partindo com SOC à $100 \%$, obtidas entre os dias 08 e 13 de fevereiro de 2019, SOC à $80 \%$, obtidas entre os dias 01 a 05 e SOC à $60 \%$, obtidas entre os dias 18 a 20, ambas em março de 2019.

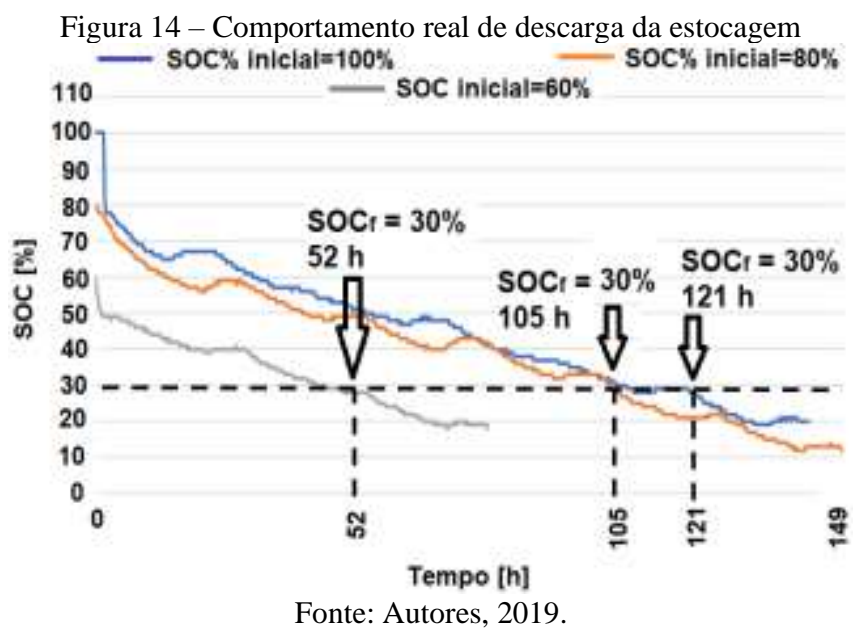

Conforme observado na Figura 14, ocorreu uma variação significativa na autonomia energética do banco de estocagem, apresentando 5,04 dias de autonomia com $\mathrm{SOC}_{\mathrm{i}}$ $=100 \%$ até $\mathrm{SOC}_{\mathrm{f}}=30 \%, 4,37$ dias com $\mathrm{SOC}_{\mathrm{i}}=80 \%$ até $\mathrm{SOC}_{\mathrm{f}}=30 \%$ e 2,16 dias com $\mathrm{SOC}_{\mathrm{i}}=60 \%$ até $\mathrm{SOC}_{\mathrm{f}}=30 \%$.

Embora na última condição $\left(\mathrm{SOC}_{\mathrm{i}}=80 \%\right.$ à $\mathrm{SOC}_{\mathrm{f}}=$ $30 \%$ ) tenha apresentado uma menor autonomia em comparação à projetada, considerando o valor limite de tensão inferior de operação do DMR e, considerando o limite máximo de descarga do BE em 20\%, atenderia, de forma satisfatória, a autonomia projetada, sem prejuízos ao 
BE e sem ocasionar a parada completa do DMR por baixa tensão. Ferreira (2015), menciona que as baterias de ciclo profundo, como as de chumbo-ácido, de grande capacidade são capazes de resistir a profundidades de descarga (DOD) de até $80 \%$, sendo a durabilidade diretamente relacionada tanto com a profundidade de descarga quanto a seus números de ciclos de carga envolvidos. Silva e Demonti (2013), mencionam que a profundidade de descarga máxima de $80 \%$ é normalmente encontrada nos manuais dos fabricantes.

\section{CONCLUSÃO}

Apesar de ocorrerem diferenças significativas entre a simulação dinâmica e a prática de campo, verificou-se de forma satisfatória a operação do $\mathrm{BE}$, diante as situações de variação e falta completa de energia solar. A simulação permitiu avaliar se o dimensionamento do BE foi correto e, caso ocorressem falhas de operação da estocagem, durante a simulação, essa seria a etapa adequada para as devidas correções, evidentemente antes da montagem de campo. Neste aspecto, a simulação atendeu plenamente aos objetivos do estudo.

Contudo, certos cuidados foram necessários quanto a interpretação dos dados, visto que Tremblay e Dessaint (2009), alertam que a validade deste modelo de bateria do Simulink é na região de SOC entre $100 \%$ e $30 \%$, por não consideraram o efeito Peukert. Também mencionam que ocorre um erro de $10 \%$ na região abaixo de $20 \%$ do estado de carga, sendo aceitável, visto que não é recomendável a descarga completa de uma bateria. Um outro detalhe é que este modelo de bateria, via Simulink, desconsidera os efeitos de variações externas de temperatura, além de considerar a resistência interna constante durante todo o processo, tanto na carga quanto na descarga, o que pode justificar os erros dos resultados da autonomia de energia, entre o modelo dinâmico e o modelo prático. Além disso, os parâmetros extraídos no processo de descarga da bateria, via experimento de bancada, os quais foram inseridos no modelo, também são considerados no processo de carga, assim, prejudicando a comparação dos dados entre simulação e realidade.

Mesmo com estas observações, destaca-se a contribuição positiva da ferramenta de simulação utilizada a qual permitiu resultados excelentes para uma avaliação prévia do experimento.

Ressalta-se que os parâmetros de simulação deste estudo não devem ser aplicados diretamente em outros trabalhos, sendo necessária uma nova modelagem dedicada a bateria utilizada.

Por fim, a autonomia de energia projetada foi plenamente atendida, comprovada na prática, através do desligamento do sistema fotovoltaico, responsável pela geração de energia.

\section{AGRADECIMENTOS}

Agradecimento especial a Companhia de Gás do Estado do Rio Grande do Sul, SULGÁS, pela disponibilização de alguns materiais e o espaço para a realização do estudo.

\section{REFERÊNCIAS}

CARVAlho, P. M. S. Modelação e Simulação de Sistemas Fotovoltaicos. 2013. 130 f. Dissertação (Mestrado em Engenharia Mecânica) - Programa de Pós-Graduação em Engenharia Mecânica, Instituto Superior de Engenharia de Lisboa, Lisboa, 2013.

Carneiro, R. L. et al.. Aspectos Essenciais das Baterias Chumbo-Ácido e Princípios Físico-Químicos e Termodinâmicos do seu Funcionamento. Revista Virtual de Química [on line]. v. 9, n.3, jun./2017, p. 889-911. ISSN 1984-6835. Disponível em: http://static.sites.sbq.org.br/rvq.sbq.org.br/pdf/v9n3a06.pdf. Acesso em 19 set. 2020.

CENTRO DE REFERENCIA PARA ENERGIA SOLAR E EÓLICA SÉRGIO BRITO - (CRESESB). Manual de engenharia para sistemas fotovoltaicos. Rio de Janeiro, $2014 . \quad$ Disponível em: <http://www.cresesb.cepel.br/index.php?section=publicacoe s\&task $=\&$ cid $=481>$. Acesso em: 27 ago. 2018.

FERREIRA, D. S. N. Estudo comparativo entre modelos computacionais e Resultados experimentais na carga e descarga de baterias de chumbo-ácido. 2015. 92 f. Trabalho de Conclusão de Curso (Graduação em Engenharia Elétrica) - Programa de Graduação em Engenharia Elétrica, Universidade Federal do Pampa (UNIPAMPA), Alegrete 2015.

FRAGA, J.R.C.P. Análise do comportamento da bateria utilizada em sistemas fotovoltaicos de pequeno porte. 2009. 155 f. Tese (Doutorado em Agronomia) Universidade Estadual Paulista (UNESP) Júlio de Mesquita Filho - Faculdade de Ciências Agronômicas - Botucatu, 2009.

MELO, L.S. et al. Dimensionamento de um sistema fotovoltaico para alimentar um sistema de produção de hidrogênio eletrolítico. In:VII Congresso Brasileiro de Energia Solar, 2018, Gramado. Anais [...] Gramado, 2018.

NETO, Antônio Faria; LOTUFO, Francisco Antônio, SANTOS, Caroline Alves dos. Armazenamento de Energia para Sistemas Elétricos. Revista Sodebras [on line]. v. 11, n.132, dez./2016, p. 253-259. ISSN 1809-3957. Disponível em: http://www.sodebras.com.br/edicoes/N132.pdf. Acesso em 19 set. 2020.

PEREIRA, N. M. C.. Simulação de regimes de carga e descarga em baterias. 2016. Dissertação (Mestrado em Engenharia Eletrotécnica) - Programa de Pós-Graduação em Engenharia Eletrotécnica de Energia e Automação, Instituto Superior de Engenharia de Lisboa, Lisboa, 2016.

RAMPINELLI, G. A. Estudo de características elétricas e térmicas de inversores para sistemas fotovoltaicos conectados à rede. 2010. 285 f. Tese (Doutorado em Engenharia) - Programa de Pós-Graduação em Engenharia Mecânica, Universidade Federal do Rio Grande do Sul (UFRGS), Porto Alegre, 2010.

SAMOUDI.A.J.K. Desing and simulation of solar photovoltaic powered cathodic protection systems. 2015. 159 f. Dissertação (Master of Clean Energy and Conservation Strategy Engineering) - Faculty of Graduate Studies, An-Najah National University, Nablus, Palestine, 2015.

SILVA, Alex de Lima e; DEMONTI, Rogers. Dimensionamento de um Sistema Fotovoltaico com Armazenamento de Energia. Revista Sodebras [on line]. v. 
8, n.91, jul./2013, p. 10-16. ISSN 1809-3957. Disponível em: http://www.sodebras.com.br/edicoes/N91.pdf. Acesso em 28 ago. 2020.

TREMBLAY, O; DESSAINT, L. A. Experimental Validation of a Battery Dynamic Model for EV Applications. World Electric Vehicle Journal, Noruega, v. 3, p. 289-298, 2009.

\section{COPYRIGHT}

Direitos autorais: Os autores são os únicos responsáveis pelo material incluído no artigo.

Submetido em: 29.08 .2020

Aprovado em: 17/09/2020 


\title{
P Revista SODEBRAS - Volume 15 $\mathrm{N}^{\circ} 178$ - OUTUBRO/ 2020 \\ MODELAGEM, SIMULAÇÃO E IMPLANTAÇÃO DE SISTEMA FOTOVOLTAICO PARA ALIMENTAÇÃO DE DISPOSITIVO DE MONITORAMENTO REMOTO DE DRENAGEM ELÉTRICA
}

\author{
MODELING, SIMULATION AND IMPLEMENTATION OF A \\ PHOTOVOLTAIC SYSTEM FOR POWERING REMOTE MONITORING \\ DEVICE OF ELECTRIC DRAINAGE
}

\author{
MÁRCIO AUGUSTO TELES DA CRUZ1; JOÃO BATISTA DIAS ${ }^{1}$ \\ 1 - LABORATÓRIO DE ENERGIA SOLAR FOTOVOLTAICA - UNIVERSIDADE DO \\ VALE DO RIO DOS SINOS \\ emailprofissional.mcruz@gmail.com; joaobd@unisinos.br
}

\begin{abstract}
Resumo - Projetou-se um sistema fotovoltaico isolado (SFI) para alimentar eletricamente um dispositivo de monitoramento remoto (DMR), destinado ao envio dos dados de operação de uma drenagem elétrica $(\mathrm{DE})$, instalada em área remota. Para a utilização dos dados de radiação no projeto do SFI, implementou-se uma modelagem e simulação em ambiente Matlab, utilizando as correlações matemáticas de Orgill e Hollands (1977) e Perez et al. (1990), de modo, a obter dados de radiação tratados para os planos de inclinação desejados. A validação do modelo de simulação ocorreu por meio de comparação de resultados com o Software Radiasol, implementado por Krenzinger e Bugs (2010). Por fim, a montagem e teste em campo permitiu avaliar, de forma prática, a operação do SFI e a comunicação da DMR, via tecnologia GPRS (General Packet Radio Service), com a sala de controle.
\end{abstract}

Palavras-chave: Sistema Fotovoltaico Isolado. Montagem experimental. Simulação.

\begin{abstract}
A Stand-alone photovoltaic system (PV) was designed to electrically power a remote monitoring device (RMD), intended to send the operating data from an electrical drain (ED), installed in a remote area. For the use of radiation data in the $P V$ project, a modeling and simulation was implemented in a Matlab environment, using the mathematical correlations of Orgill and Hollands (1977) and Perez et al. (1990), in order to obtain treated radiation data for the desired inclination planes. The validation of the simulation model occurred by comparing results with the Radiasol Software, implemented by Krenzinger and Bugs (2010). Finally, the assembly and test in the field allowed to evaluate, in a practical way, the operation of the SFI and the communication of the RMD, via GPRS (General Packet Radio Service) technology, with the control room.
\end{abstract}

Keywords: Stand-alone Photovoltaic System. Experimental system. Simulation.

\section{INTRODUÇÃO}

A análise remota proporciona a detecção de possíveis anomalias e disfunções, relacionadas a danos ou deterioração dos componentes do sistema de proteção catódica, no caso deste estudo, uma drenagem elétrica (DE). Logo, com esta aplicação, diagnósticos a distância, como a perda de um retificador de proteção catódica, danos na DE, entre outros, torna o atendimento de manutenções corretivas, mais eficaz e em tempo hábil (MAGNIFICO, 2018).

O sistema fotovoltaico isolado (SFI), ou off-grid, comumente empregado para alimentação elétrica de equipamentos remotos, visa atender a uma demanda energética específica. Logo, torna-se necessário tanto conhecer a demanda da carga quanto a estimativa de geração de energia (CRESESB, 2014).

Segundo Cresesb (2014), os dados de radiação, essenciais para o projeto de um sistema fotovoltaico, são disponibilizados na forma de radiação global no plano horizontal e devem ser tratados e modelados para o plano inclinado desejado. Para isso, são empregados meios computacionais, utilizando modelos matemáticos apropriados para a escala temporal desejada. Existe também a necessidade de conhecimento das parcelas de radiação direta e difusa, primordiais para a modelagem destes dados (CRESESB, 2014).

Para definir uma das componentes, a radiação difusa, correlações estatísticas foram desenvolvidas como a proposta por Erbs et al. (1982 apud DUFFIE; BECKMAN) e por Orgill e Hollands (1977). Estas correlações relacionam a irradiação difusa horária $I_{d}$ e a irradiação global horária $I$, sendo esta última, disponibilizada pela estação meteorológica. A relação $\mathrm{I}_{d} / \mathrm{I}$, resulta em um coeficiente de difusidade, definido como $k_{d}$. Outro coeficiente aplicado a estas correlações é o índice de claridade horário $k_{t}$, definido como a relação entre a irradiação global horária $(I)$ e a irradiação extraterrestre $\left(I_{0}\right)$, ou seja, uma relação $I / I_{0}$. Para o modelo de Orgill e Hollands (1977), $k_{d}$, poderá ser, $I_{d} / I=1$ $0,249 k_{t}$; para $0 \leq k_{t} \leq 0,35$, ou $I_{d} / I=1,577-1,84 k_{t}$; para $0,35<k_{t}<0,75, I_{d} / I=0,177$; para $k_{t}>0,75$. Com a obtenção do índice $k_{d}$ da correlação de Orgill e Hollands (1977), aplicase $I_{d}=I k_{d}$ para obter a componente de radiação difusa $\mathrm{I}_{\mathrm{d}}$. Logo, a componente de radiação direta $I_{b}$, passa a ser $I_{b=} I$ $I_{d}$. Para estimar a irradiação global em uma superfície arbitrariamente inclinada são utilizados modelos matemáticos os quais possuem particularidades no que tange o tratamento da parcela da radiação difusa, como o modelo 
de Perez et al. (1990) que trata a anisotropia da irradiação difusa (DUFFIE; BECKMAN, 2013).

Em relação a aplicação dos dados de irradiação modelados, Melo et al. (2018), aplicou em seu trabalho a metodologia do mês crítico, citada pelo Cresesb (2014), a qual considera para dimensionamento do SFI o mês mais desfavorável na relação carga/irradiação. Contudo, segundo Cresesb (2014), gera excesso de energia nos demais meses do ano.

Os cálculos, segundo Cresesb (2014), são necessários para garantir o pleno atendimento ao projeto fotovoltaico. Metodologias de cálculo aplicadas ao trabalho de Melo et al. (2018), Rampinelli (2010) e Samoudi, (2015), partiram de dados de irradiação tratados, de uma boa estimativa de consumo das cargas, seguindo para o dimensionamento dos equipamentos do sistema de controle e condicionamento de potência.

O objetivo deste artigo é apresentar os resultados de uma modelagem e simulação computacional, dedicada para o tratamento dos dados de radiação global horizontal, de forma a aplicá-los no projeto de um SFI. O objetivo deste SFI é alimentar eletricamente um dispositivo DMR, dedicado exclusivamente para monitorar a operação de um equipamento DE.

\section{JUSTIFICATIVA}

Justifica-se a elaboração deste estudo como forma de avaliar a eficácia do SFI, projetado para manter a alimentação elétrica da DMR constante, de modo que ela possa, sempre que necessário, comunicar/alarmar, via GPRS, as eventuais anomalias ou falhas no sistema de mitigação, neste caso a DE, de modo a proporcionar a tomada de decisão em tempo hábil.

\section{METODOLOGIA}

Optou-se, neste estudo, seguir uma sequência como a proposta pelo Cresesb (2014), o qual menciona iniciar o dimensionamento de um sistema fotovoltaico estimando o recurso solar disponível. Na sequência, definiu-se a demanda energética da carga, com base nos dados do fabricante. Com as informações de demanda da carga e produtividade de referência, definiu-se a potência necessária para o sistema de geração de energia. Como trata-se de um SFI, define-se uma quantidade mínima de armazenamento de energia, de modo a atender ao consumo da carga nos momentos onde não há geração de energia, assim como, um controlador de carga e descarga para o BE. Por fim, a montagem do experimento a qual ocorreu nas dependências da empresa Sulgás, parte interessada, onde foi avaliada a operação do DMR. Os detalhes da metodologia adotada, para cada etapa do trabalho, são descritos na sequência.

\section{1 - Modelagem e simulação para a estimativa do recurso solar disponível}

A correlação de Orgill e Hollands (1977) foi adotada na modelagem e simulação computacional deste estudo para obtenção da componente horária de radiação difusa. Optouse pela utilização deste modelo matemático, devido a proporcionar, segundo Duffie e Beckman (2013), resultados para fins práticos, semelhantes a correlação proposta por Erbs et al. (1982 apud DUFFIE; BECKMAN). Já, para estimar a componente de radiação global horária para o plano inclinado, aplicou-se o modelo de Perez et al. (1990), segundo Duffie e Beckman (2013), largamente empregada.

Logo, a estimativa de radiação global horária para o plano arbitrariamente inclinado $I_{T}$ é definida pela aplicação da Equação 1 (DUFFIE; BECKMAN, 2013).

$$
\begin{aligned}
& I_{T}=I_{b} R_{b+} I_{d}\left(1-F_{1}((1+\cos \beta) / 2)\right)+I_{d} F_{1}(a / b)+ \\
& I_{d} F_{2} \operatorname{sen} \beta+I \rho_{g}((1-\cos \beta) / 2)
\end{aligned}
$$

Segundo Duffie e Beckman (2013), $F_{1}$ o coeficiente de brilho solar circunsolar e o $F_{2}$ coeficiente de brilho solar no horizonte, são calculados a partir de dados da tabela do índice de transparência do céu $\epsilon$. Os termos 'a' e 'b' são dependentes do ângulo de incidência da radiação solar direta sobre uma superfície com determinada orientação. $\mathrm{O}$ dado de $I \rho_{g}$, corresponde a radiação solar refletida horária. Já o termo $R_{b}$, é definido pela razão entre o ângulo de incidência $\theta_{S}$ e o ângulo zenital $\theta_{Z}$ (DUFFIE; BECKMAN, 2013).

No Matlab, efetuou-se as simulações computacionais para avaliação dos melhores ângulos de geração de energia sendo, $20^{\circ}, 25^{\circ}, 30^{\circ}, 35^{\circ}$ e $40^{\circ}$, uma variação da latitude local, neste caso, $30^{\circ}$. Cresesb (2014), menciona que o gerador fotovoltaico pode estar dentro de $10^{\circ}$, para mais ou para menos, em torno da latitude do local, sem prejuízo a geração de energia anual. Os dados horários de radiação global horizontal de um ano, disponibilizados pelo INMET, referentes à estação automática A801 de Porto Alegre, são aplicados nas correlações matemáticas do programa. Com isso, obteve-se os dados de radiação global para o plano inclinado, referente a estes ângulos. A seleção do ângulo $\beta$ define-se em relação à máxima energia gerada ao longo do ano, seguindo uma das definições propostas pelo Cresesb (2014).

Quanto a validação do algoritmo de cálculo, desenvolvido em Matlab, ocorreu mediante comparação de resultados entre a simulação numérica e Software Radiasol, este, implementado por Krenzinger e Bugs (2010), além da obtenção de desvio médio percentual aceitável, conforme metodologia aplicada por Rampinelli e Krenzinger (2009). Optou-se por este programa por ser gratuito, por utilizar correlações semelhantes ao modelo a ser validado e, conforme Krenzinger e Bugs (2010), muito utilizado por pesquisadores da área de energia solar.

\section{2 - Características das cargas}

As cargas a serem considerados no projeto do SFI são a remota e os conversores. A remota, dispositivo de aquisição de dados e comunicação via GPRS, possui, segundo o fabricante, uma potência requerida de 3,6 W e, uma tensão de alimentação mínima de $11,8 \mathrm{~V}$ e máxima de 15,4 V. Os conversores, segundo Franchi (2015), possuem a função de traduzir um sinal de entrada para outro tipo na saída, no caso deste estudo, uma variável de tensão para uma outra de corrente, sendo ela de 4 a $20 \mathrm{~mA}$, típica de instrumentação e controle. Conforme o fabricante, estes conversores, possuem uma demanda de potência unitária de $1,26 \mathrm{~W}$ e devendo a tensão de alimentação possuir no mínimo 11,8 V e máxima de 13,7 V. Logo, a carga total, composta por uma remota e quatro conversores, compondo uma DMR, totalizam uma potência de 8,64 W. 


\section{3 - Dimensionamento dos módulos fotovoltaicos}

O método de dimensionamento do SFI, aplicado a este estudo, trata da avaliação do período que representa as condições mais desfavoráveis para a geração de energia, neste caso, o mês crítico. A produtividade de referência $Y_{r}$ do mês crítico é considerada o primeiro passo para o dimensionamento da potência do gerador fotovoltaico $P_{F V}$, segundo Cresesb (2014), assim como a informação de carga $P_{L}$, estimada no item 3.3. Aplicadas ao trabalho de Melo et al. (2018) e Rampinelli (2010), as Equações (2), (3), (4) e (5), foram adaptadas e utilizadas no dimensionamento do SFI. A Equação (2), H( $\gamma, \beta)$, corresponde a irradiação do mês crítico em relação ao plano do arranjo fotovoltaico para o desvio azimutal $\gamma$ e inclinação do arranjo $\beta$. Da Equação (3), obteve-se a produtividade de referência $Y_{r}$. A Equação (4), o consumo de energia da carga $\epsilon_{c}$. Com a Equação (5) é obtida a potência requerida para o gerador fotovoltaico $P_{F V}$.

$$
\begin{aligned}
& H(\gamma, \beta)=\int G(t) d t \\
& Y_{r}=H(\gamma, \beta) / G_{S T C} \\
& \epsilon_{c}=24 P_{L} \\
& P_{F V}=\epsilon_{d} / Y_{R}
\end{aligned}
$$

Definiu-se a quantidade de módulos pela aplicação da Equação (6), onde $P_{F V}$, corresponde a potência dimensionada para o gerador fotovoltaica e o valor 50, corresponde a potência unitária do módulo, fabricante Solarterra, conforme a Tabela 1. Sendo assim, $N_{\text {mod }}$ corresponde ao número de módulos fotovoltaicos a serem utilizados (SAMOUDI, 2015).

$$
N_{\text {mod }}=P_{F V} / 50
$$

Tabela 1 - Especificação técnica do módulo monoclistalino

\begin{tabular}{ll}
\hline Item & Valor \\
\hline Potência máxima $\left[\mathrm{P}_{\max }\right]$ & $50 \mathrm{~W}_{\mathrm{p}}$ \\
Tensão circuito aberto $\left[\mathrm{V}_{\mathrm{oc}}\right]$ & $21,88 \mathrm{~V}$ \\
Corrente curto-circuito [ $\left.\mathrm{I}_{\mathrm{sc}}\right]$ & $2,99 \mathrm{~A}$ \\
Eficiência do módulo [\%] & 10,5 \\
Número de Células [-] & 36 \\
\hline
\end{tabular}

Fonte: Autores, 2019.

\section{4 - Dimensionamento do banco de estocagem}

$\mathrm{O}$ banco de estocagem (BE) tem o objetivo de atender a demanda quando ocorrer baixa ou a falta completa de radiação solar. Um dado que está relacionado com a vida útil do BE é a profundidade de descarga $P_{d}$. Valores comumente empregados em ciclos de descarga rasos são de $20 \%$ a $40 \%$ e, para ciclos profundos são de $50 \%$ a $80 \%$ (CRESESB, 2014). A capacidade nominal do banco de estocagem $C_{A h}$, a qual corresponde ao total de carga que deve ser armazenada, é definida pela Equação (7). Este valor, no entanto, é dependente de $P_{d}$ (considerado no dimensionamento, 50\%) e a eficiência da capacidade da bateria (adotado no dimensionamento, 90\%) (SAMOUDI, 2015).

$$
C_{A h}=\left(\epsilon_{c} /\left(V_{\text {nom }} \eta_{\text {bateria }} P_{d}\right)\right) N
$$

onde $N$ representa a autonomia do BE. Logo, a bateria selecionada para compor o banco de estocagem foi a de chumbo-ácido, da marca Global, selada e regulada a válvula (VRLA) de tensão nominal $V_{\text {nom }}$ de $12 \mathrm{~V}$, capacidade em $\mathrm{C}_{20}$ de 15 Ah. A tensão de flutuação, conforme dados do fabricante é de 13,6 a 13,8 V, cíclico de 14,6 a $15 \mathrm{~V}$ e corrente inicial máxima de 4,5 A. Segundo Ferreira (2015), o acréscimo de baterias em paralelo ocasiona o aumento do armazenamento de energia, proporcionando maior capacidade nominal $C_{A h}$, sem prejuízo a tensão, pois permanece constante.

Em referência ao valor de $N$ da Equação (7) é destacado pelo Cresesb (2014) que pode ser adotado para o Brasil o equivalente entre 2 a 4 dias ( 48 a 96 h).

O número de baterias $N_{b a t}$ em paralelo para compor o banco de estocagem definiu-se pela aplicação da Equação (8), onde $C_{20}$, corresponde a capacidade unitária da bateria (RAMPINELLI, 2010).

$$
N_{b a t}=C_{A h} / C_{20}
$$

\section{5 - Dimensionamento do controlador de carga}

Definiu-se o controlador de carga com base nos fatores de tensão e corrente de operação, tanto na entrada, proveniente do módulo fotovoltaico quanto na saída, ligada ao $\mathrm{BE}$, além do tipo de bateria. Para a corrente $I_{C}$ do controlador, acrescentou-se 25\%, conforme Melo et al. (2018), considerando uma irradiância máxima de 1250 $\mathrm{W} / \mathrm{m}^{2}$, ainda que por poucos períodos. A aplicação da Equação (9) fornece a corrente $I_{C}$ desejada para o controlador de carga, onde $N_{\text {mod }}$, corresponde ao número de módulos em paralelo e $I_{S C}$ a corrente de curto-circuito do módulo (CRESESB, 2014).

$$
I_{S C}=1,25 I_{S C} N_{\bmod }
$$

Para a máxima tensão do controlador $V_{C(m a ́ x)}$, deverá ser a máxima tensão de circuito aberto do módulo fotovoltaico, em relação à menor temperatura a ele aplicada. Na prática, a máxima tensão do controlador deverá respeitar a seguinte relação: $V_{C(\text { máx })}>V_{O C(\text { mín. })}($ CRESESB, 2014).

\section{6 - Montagem e metodologia de avaliação de dados do modelo experimental}

Após etapa de dimensionamento, parte-se para a montagem do experimento. Isso permitirá avaliar, de forma prática, a operação do SFI e a comunicação da DMR com a sala de controle. A Figura 1, ilustra as ligações elétricas efetuadas e explicadas na sequência.

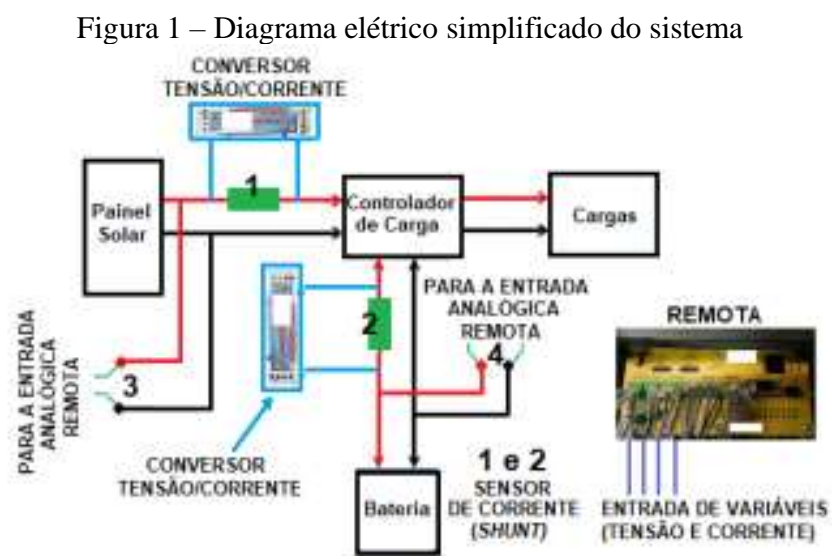

Fonte: Autores, 2019. 
As ligações elétricas deste experimento estão da seguinte forma, como mostra a Figura 1: a tensão gerada pelo painel fotovoltaico (ponto 3) e a tensão do BE (ponto 4), são ligadas diretamente as entradas analógicas da remota (modem GPRS) e ao controlador de carga. Os condutores do painel fotovoltaico (ponto 1) e do BE (ponto 2), foram ligados à dois conversores que recebem na entrada tensões de 0 a $60 \mathrm{mV}$, proveniente dos sensores shunt, ligados em série ao circuito. Estes conversores operaram conforme definido por Franchi (2015), traduzindo a variação, correspondente a entrada $(0 \mathrm{a} 60 \mathrm{mV})$, na forma de corrente (4 a $20 \mathrm{~mA}$ ) na saída. Todos estes dados gerados são enviados via tecnologia GPRS à sala de supervisão e controle, onde serão armazenados hora a hora em um banco de dados, na forma de tensão e corrente, correspondente aos reais valores de campo, permitindo avaliá-los, posteriormente.

\section{RESULTADOS}

Os resultados com base nas simulações sobre o modelo matemático adotado, do equacionamento e, da operação do experimento, são apresentados na sequência.

\section{1 - Resultados quanto a validação do modelo}

Para a validação do modelo de cálculo da radiação solar global para o plano inclinado $\beta$, seguiu-se a metodologia proposta por Rampinelli e Krenzinger (2009), descrita no item 3.1, deste estudo. Os mesmos dados de radiação solar global para o plano horizontal foram inseridos tanto no Radiasol quanto no modelo elaborado, ambos com desvio azimutal $\gamma$ de $180^{\circ}$ (orientação Norte Verdadeiro). O modelo desenvolvido em Matlab apresentou um desvio percentual médio de $0,27 \%$ para o ângulo de inclinação $\beta=0^{\circ}$, enquanto para o ângulo de $\beta=20^{\circ}$ de $8,81 \%$. Já para o ângulo de inclinação $\beta=30^{\circ}$, apresentou um desvio percentual médio de $11,65 \%$. As Figuras 2, 3 e 4, mostram a comparação dos resultados entre o Radiasol e o modelo numérico.
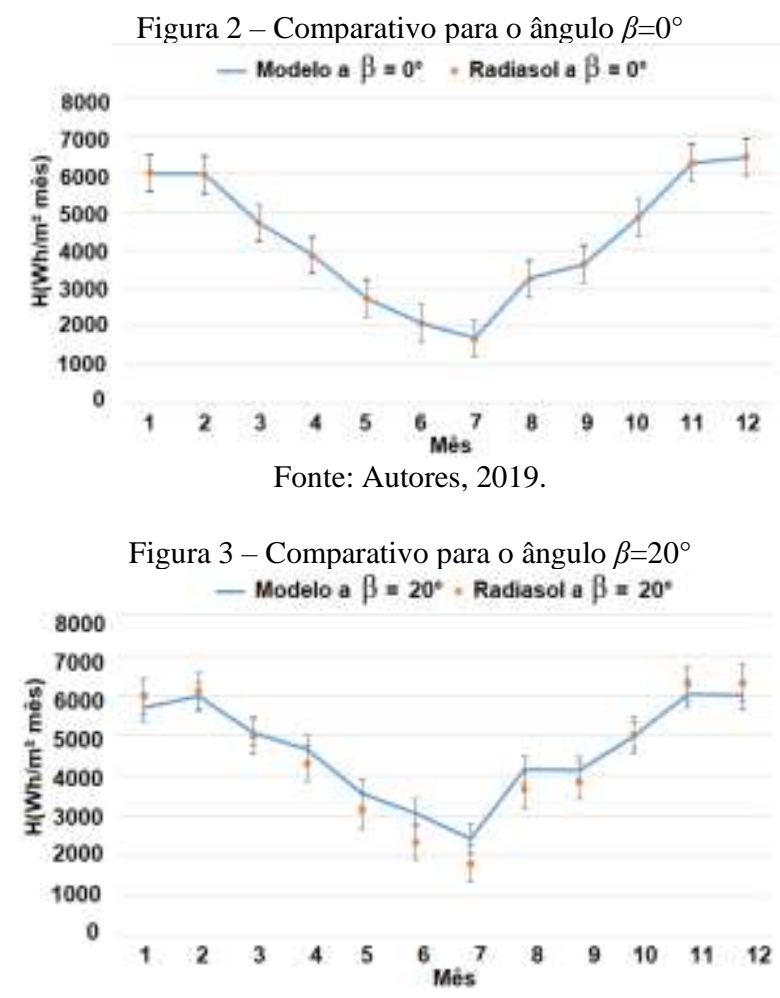

Fonte: Autores, 2019.

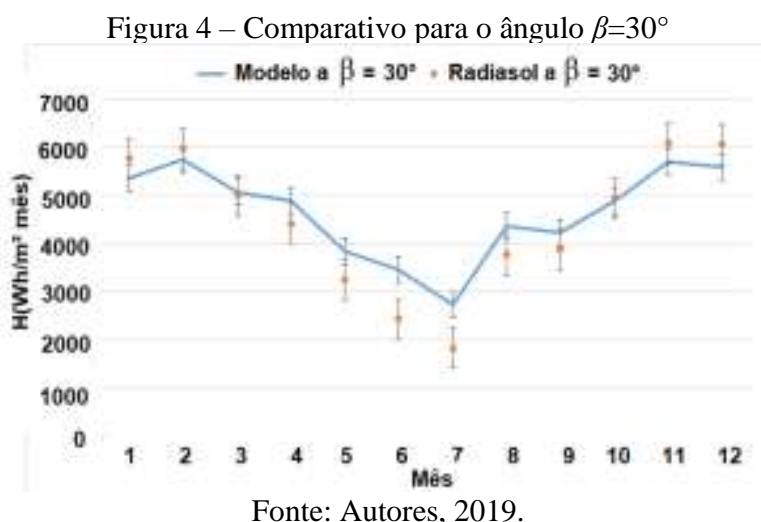

A aplicação dos modelos matemáticos de Orgill e Hollands (1977) e Perez et al. (1990), na rotina computacional desenvolvida em Matlab, obteve-se resultados bastante satisfatórios, quando comparados ao programa Radiasol.

\section{2 - Resultados em relação a estimativa do recurso solar disponível}

A partir do modelo de cálculo validado, conforme item 4.1, estimou-se a produção de energia em relação aos ângulos de $20^{\circ}, 25^{\circ}, 30^{\circ}, 35^{\circ}$ e $40^{\circ}$. Com base nestes resultados, definiu-se o melhor ângulo de geração de energia para posterior aplicação no projeto do SFI. Na Figura 5 é possível verificar o potencial de produção de energia ao longo do ano, através da alteração do parâmetro $\beta$, para os ângulos mencionados anteriormente.

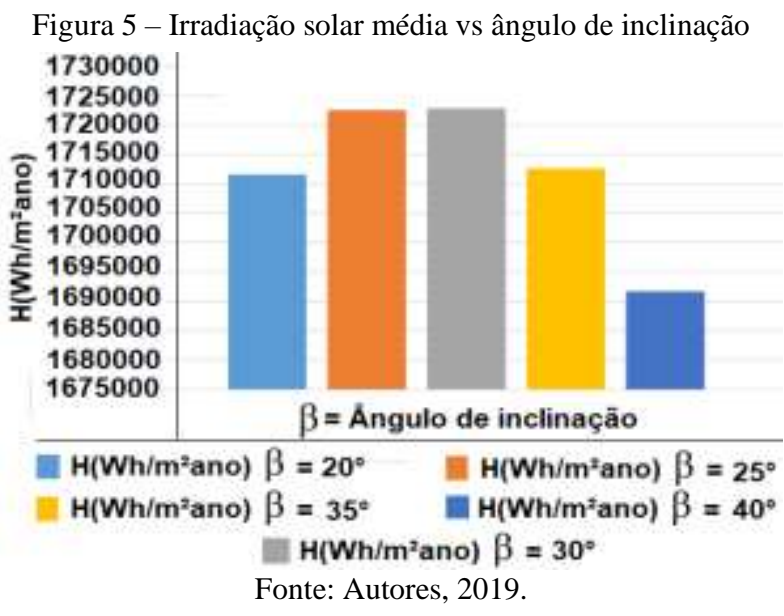

Conforme Cresesb (2014), a máxima geração de energia ao longo do ano ocorre, preferencialmente, para o ângulo de inclinação igual a latitude do local, podendo ocorrer pequenas variações as quais não implicam em grandes mudanças. Isso pode ser percebido entre os ângulos de $25^{\circ}$ a $30^{\circ}$ os quais permitiram uma produção de energia semelhante, sendo $30^{\circ}$ um pouco maior. Através deste resultado, fica evidenciado a seleção do ângulo $\beta=30^{\circ}$ para aplicação no projeto.

Na Figura 6, verifica-se que o mês mais desfavorável (crítico) para a geração de energia foi julho de 2018, para o ângulo de inclinação de $30^{\circ}$, selecionado após análise do ângulo de máxima produção de energia. Na Tabela 2, destacase que $Y_{r}$, no mês crítico, possui os piores resultados, em referência ao ângulo $30^{\circ}$. Logo, para o dimensionamento do SFI considerou-se o $Y_{r}$ para o ângulo de inclinação de $30^{\circ} \mathrm{o}$ qual totalizou 2,73 h/dia. 
Figura 6 - Irradiação solar média para os meses do ano

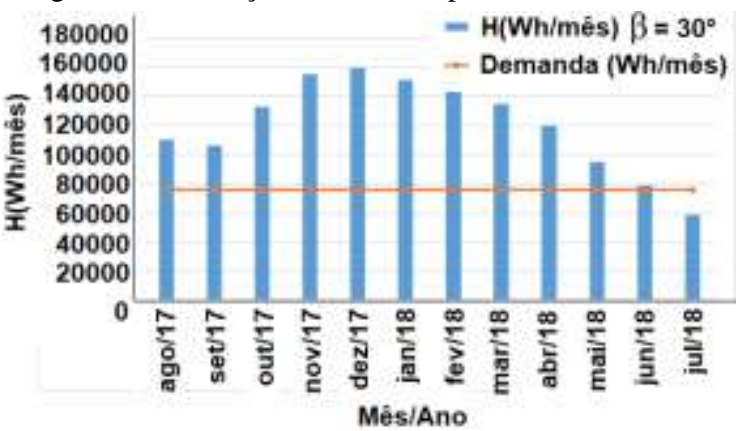

Fonte: Autores, 2019.

Tabela 2 - Produtividade de referência

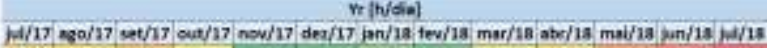

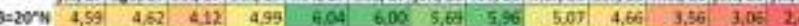

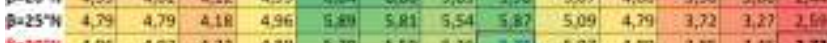

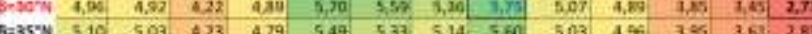

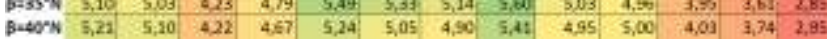
Fonte: Autores, 2019.

\section{3 - Resultados do equacionamento}

Efetuou-se o dimensionamento do SFI com base nos dados de $P_{L}$ e $Y_{r}$, sendo este último, obtido na simulação, detalhada no item 4.2. Do equacionamento, conforme Melo et al. (2018), definiu-se 2 módulos fotovoltaicos para a geração de energia elétrica e 8 baterias VRLA, na configuração paralela para o atendimento da autonomia de 3 dias. O controlador de carga foi definido com base no cálculo de $I_{C}$ e, na máxima tensão de circuito aberto que o dispositivo deve operar. Com isso, o controlador selecionado foi da marca Epever, modelo LS2024B, com limite de corrente de 20 A e uma tensão superior a $40 \%$ de

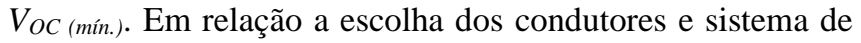
proteção, seguiu-se o proposto por Melo et al. (2018), com a consulta à Norma NBR 5410. Com isso, dimensionou-se o condutor de $2,5 \mathrm{~mm}^{2}$, o qual possui capacidade de condução de corrente de 19,5 A e isolação apropriada tanto para a radiação UV quanto para operações em temperatura até $70^{\circ} \mathrm{C}$. Para o sistema de proteção, disjuntores, seguiu-se o proposto pela NBR 5410, a qual recomenda $I_{B} \leq I_{N} \leq I_{Z}$, sendo, $I_{N}$ a corrente nominal do disjuntor (10 A), $I_{B}$ a corrente máxima do circuito de geração $2 I_{S C}$ e a corrente de carga das baterias $2 I_{S C}-0,42$, sendo 0,42 A a corrente fixa de consumo do SMR (carga) e, $I_{Z}$ a capacidade de condução de corrente dos condutores (19,5 A). Conforme item 4.2, os módulos foram inclinados a $30^{\circ}$ em relação ao solo e face orientada ao norte geográfico. A Figura 7 apresenta os resultados do equacionamento.

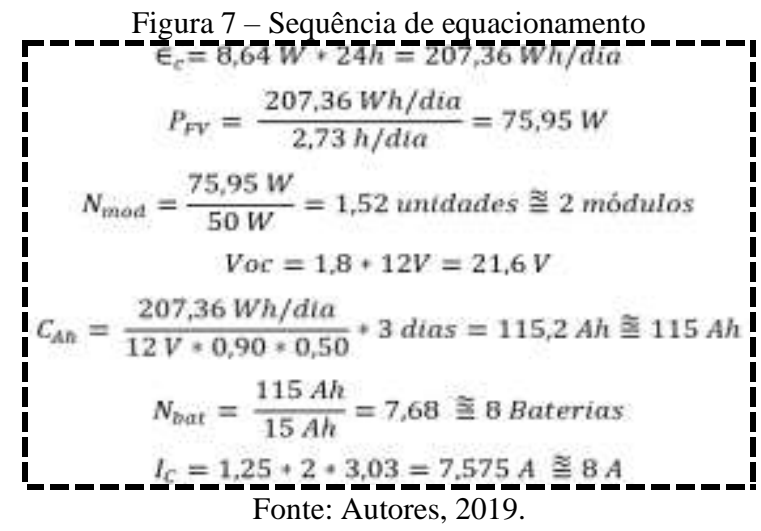

A Figura 8, apresenta a montagem do experimento (SFI + DMR), nas dependências na empresa Sulgás, localizada no município de Canoas, RS.

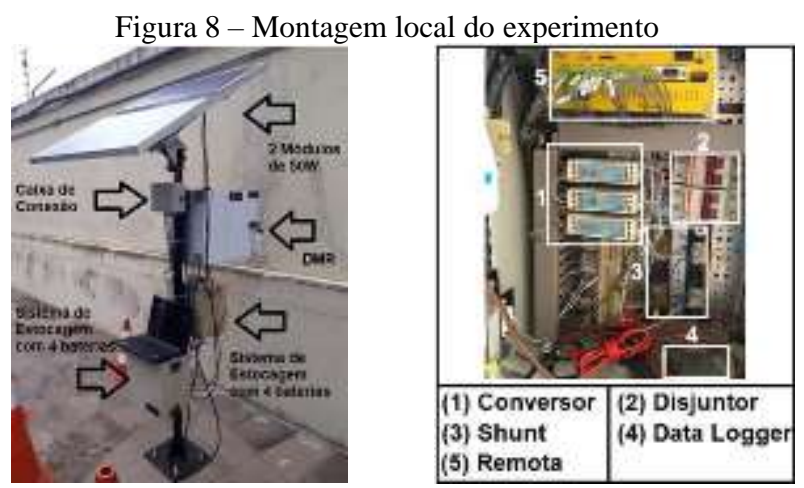

Fonte: Autores, 2019.

\section{4 - Resultados da operação do experimento}

Com a montagem experimental avaliou-se, de forma prática, o comportamento do SFI entre o período de janeiro a julho de 2019. A Figura 9, demonstra a operação do SFI, entre os dias 15 a 18 de fevereiro de 2019, mês considerado não crítico, partindo com o $\mathrm{BE}$ a um estado de carga de $33 \%$. Pode ser observado que a estocagem atingiu, em 3 dias, o estado de carga máximo, para uma corrente de carga média de 2,1 A, com pico máximo de 6,67 $\mathrm{A}$.

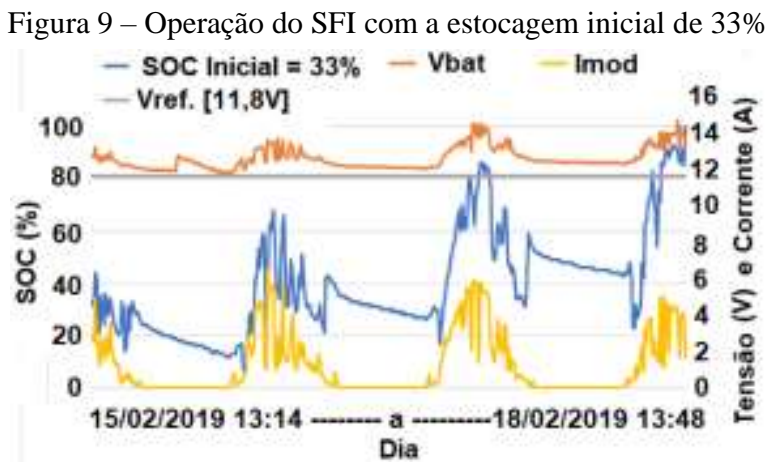

Fonte: Autores, 2019.

A Figura 10 mostra a operação do SFI no mês considerado como crítico, julho de 2019. Foi observado a não ocorrência de perturbações significativas na alimentação elétrica, as quais poderiam causar a falha de operação do SMR. Nesta mesma figura, as setas vermelhas estão indicando os dias que apresentaram valores médios de corrente máxima gerada de 0,9 A a 1,41 A. Já o estado de carga e a tensão, valores mínimos, seta azul, foram de $12 \%$ e $12,1 \mathrm{~V}$, respectivamente.

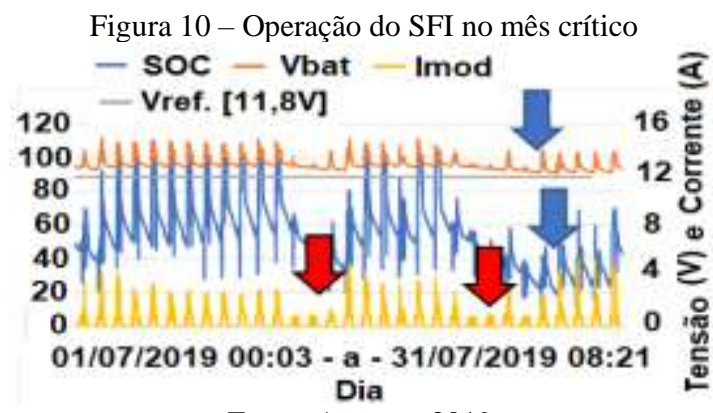

Fonte: Autores, 2019. 
Em nenhuma das operações acima, Figuras 9 e 10, a alimentação elétrica dos instrumentos atingiu os valores críticos de operação. Os dados, em formato CSV (CommaSeparated Values), obtidos hora a hora via sistema SCADA (Supervisory Control and Data Acquisition), foram tratados em planilha Excel. Como a comunicação da DMR e sala de controle ocorre via GPRS e, não ocorreram falhas de transmissão destes dados, durante o período de avaliação, considerou-se satisfatória a operação do modelo experimental, tratando-o como confiável.

\section{CONCLUSÃO}

O modelo de cálculo adotado neste estudo e implementado no Matlab, gerou bons resultados, assim como a metodologia de dimensionamento do SFI.

Durante a avaliação prática do experimento, percebeuse uma situação de criticidade para a situação de carga parcial do BE ao final do dia, seguida por dias subsequentes de baixa radiação. Isso pode ser contornado através da adição de mais um módulo fotovoltaico com as mesmas características. Este incremento proporcionará um aumento da corrente de carga, de modo que ocorrerá o carregamento mais rápido do $\mathrm{BE}$, mesmo nos dias parcialmente encobertos. Outra possibilidade seria a instalação de conversores com menor consumo de energia. Isto pode contribuir para que o BE não atinja, ao final do dia, um estado de carga crítico, abaixo de $20 \%$, que ocasiona a redução da vida útil da bateria, como mencionado pelo fabricante.

Destaca-se a contribuição positiva deste experimento o qual permitiu, com base nos resultados, justificar a extensão do monitoramento aos demais equipamentos da empresa, instalados em área remota.

\section{AGRADECIMENTOS}

Agradecimento especial a Companhia de Gás do Estado do Rio Grande do Sul, SULGÁS, pela disponibilização de alguns materiais e o espaço para a realização do estudo.

\section{REFERÊNCIAS}

ABNT, A. B. D. N. T. NBR 5410/2004: Instalações elétricas de baixa tensão. Rio de Janeiro: [s.n.], 2004. 209 p. Acesso em: 8 de janeiro 2019.

FRANCHI, C. M.. Instrumentação de processos industriais: princípios e aplicações. 1 ed. São Paulo: Érica, 2015. p.24-32.

CENTRO DE REFERÊNCIA PARA ENERGIA SOLAR E EÓlICA SÉRGIO BRITO - (CRESESB). Manual de engenharia para sistemas fotovoltaicos. Rio de Janeiro, $2014 . \quad$ Disponível em: $<$ http://www.cresesb.cepel.br/index.php?section=publicacoe s\&task=\&cid=481>. Acesso em: 27 ago. 2018.

FERREIRA, D. S. N. Estudo comparativo entre modelos computacionais e Resultados experimentais na carga e descarga de baterias de chumbo-ácido. 2015. $92 \mathrm{f}$. Trabalho de Conclusão de Curso (Graduação em Engenharia Elétrica) - Programa de Graduação em Engenharia Elétrica, Universidade Federal do Pampa (UNIPAMPA), Alegrete 2015.
MAGNÍFICO, I.. Advantages in using remote monitoring to assess effectiveness of Cathodic: Protection in stray current affected áreas. CEOCOR, Committee on the Study of Pipe Corrosion and Protection. Ancona, Itália, 2018. Paper, 13 p. Disponível em: < https://ceocor.lu/download/2018_straford_proceedings/2018 -25-Paper-MAGNIFICO-Advantages-in-using-remotemonitoring-to-assess-effectiveness-of-Cathodic-Protectionin-stray-current-affected-areas.pdf $>$. Acesso em: 30 set. 2020 .

DUFFIE, J. A.; BECKMAN, W. A. Solar engineering of thermal processes. 4. ed. New Jersey. Wiley, 2013. p.3-96.

KRENZINGER, A.; BUGS, R. C. RADIASOL2 software para sintetizar dados de radiação solar In: IV CONFERENCIA LATINO AMERICANA DE ENERGIA SOLAR e XVII SIMPÓSIO PERUANO DE ENERGIA SOLAR. 1-5, 11, 2010, Cuzco. Anais [...]. Cuzco: IV ISES CLA e XVII SPES, 2010.

INSTITUTO NACIONAL DE METEOROLOGIA (INMET). INMET: Cidade: Rio Grande do Sul: Porto Alegre: dados estação automática a801. Disponível em: < http://www.inmet.gov.br/portal/index.php?r=estacoes/estaco esAutomaticas >. Acesso em: 29 jul. 2018.

MELO, L.S. et al. Dimensionamento de um sistema fotovoltaico para alimentar um sistema de produção de hidrogênio eletrolítico. In: VII Congresso Brasileiro de Energia Solar, 2018, Gramado. Anais [...] Gramado, 2018.

ORGILL, F. J; HOLLANDS, K. G. T. Correlation Equation for Hourly Diffuse Radiation on a Horizontal Surface. Solar Energy, Great Britain, v. 19, n. ?, p. 357-359, 1977.

PEREZ, R., P.et al. Modeling Daylight Availability and Irradiance Components from Direct and Global Irradiance. Solar Energy, Estados Unidos, v. 44, n. 5, p. 271-289, 1990.

RAMPINELLI, G. A. Estudo de características elétricas e térmicas de inversores para sistemas fotovoltaicos conectados à rede. 2010. 285 f. Tese (Doutorado em Engenharia) - Programa de Pós-Graduação em Engenharia Mecânica, Universidade Federal do Rio Grande do Sul (UFRGS), Porto Alegre, 2010.

RAMPINELLI, G. A., KRENZINGER, A. Descrição de um programa computacional de simulação de sistemas fotovoltaicos conectados à rede elétrica de distribuição. Avances em Energias Renovables y Medio Ambiente. Argentina, v. 13, 2009.

SAMOUDI.A.J.K. Desing and simulation of solar photovoltaic powered cathodic protection systems. 2015. 159 f. Dissertação (Master of Clean Energy and Conservation Strategy Engineering) - Faculty of Graduate Studies, An-Najah National University, Nablus, Palestine, 2015.

\section{COPYRIGHT}

Direitos autorais: Os autores são os únicos responsáveis pelo material incluído no artigo.

Submetido em: 08/09/2020 Aprovado em: 08/10/2020 


\title{
Revista SODEBRAS - Volume 15 \\ $\mathrm{N}^{\circ} 178$ - OUTUBRO/ 2020
}

\section{DESENVOLVIMENTO DE FERRAMENTA PARA OTIMIZAÇÃO DO MÉTODO DE REDUÇÃO DE RISCOS CONTRATUAIS EM EMPREITADAS NA CONSTRUÇÃO CIVIL}

\section{DEVELOPMENT OF TOOL FOR OPTIMIZING THE METHOD OF REDUCING CONTRACTUAL RISKS IN CIVIL CONSTRUCTION CONTRACTORS}

\author{
1 - MÔNICA MIRANDA DE CARVALHO ${ }^{1}$; ANA REGINA SANTOS DE CAMARGO²; \\ ADRIANA DE PAULA LACERDA SANTOS ${ }^{3}$ \\ $1 ; 2 ; 3$ - CURSO DE ESPECIALIZAÇÃO EM GESTÃO DE SUPRIMENTOS - UFPR \\ monicamirandadc@gmail.com; camargoanaregina@gmail.com; adrianaplsl@gmail.com
}

\begin{abstract}
Resumo - O presente artigo apresenta uma ferramenta criada para reduzir os riscos de contratação de fornecedores empreiteiros por empresas situadas no setor da construção civil. Foram utilizados os dados relativos a decisões judiciais proferidas sobre casos de litígio em contratos de empreitada, nas esferas cível e trabalhista, dos tribunais paranaenses. Através da aplicação da curva ABC ou diagrama de Pareto, são identificados cinco grandes focos de litígio e, consequentemente, delineados os principais pontos de risco. Apresentam-se soluções práticas e automatizadas sobre os riscos levantados. Como consequência, tem-se que a aplicação da ferramenta é capaz de auxiliar a redução dos riscos e pode auxiliar na otimização dos processos adstritos ao universo da gestão de contratos.
\end{abstract}

Palavras-chave: Gestão de Contratos. Empreiteira. Otimização. Redução de Riscos.

\begin{abstract}
This article presents a tool created to reduce the risk of contracting suppliers by companies located in civil construction sector. The data related to the judicial decisions handed down on cases of litigation in works contracts, in the civil and labor spheres, of the courts of Paraná were used. By applying the $A B C$ curve or Pareto Diagrams, five major areas of litigation are identified and, consequently, the main risk points are outlined. Practical and automated solutions are presented on the risks raised. As a consequence, the application of the aforementioned tool is capable of helping to reduce risks and can assist in the optimization of processes attached to the universe of contract management.
\end{abstract}

Keywords: Contract Management. Contractor. Optimization. Risk Reduction.

\section{INTRODUÇÃO}

O processo de seleção do prestador de serviço, geralmente, não avalia qualitativamente o respectivo perfil, concentrando a análise, via-de-regra, sobre o preço da proposta e valores fixados em orçamento de projeto. Desta forma, podem aparecer eventuais falhas na escolha do fornecedor, uma vez que a utilização de poucos critérios extirpa outros parâmetros importantes para o estabelecimento de critérios de seleção.

Ressalta-se, outrossim, que a contratação de empreiteiros na construção civil, além de caracterizar modalidade contratual importantíssima para o ramo, está sujeita a legislação civil e trabalhista muito específicas (arts.
610 a 626 do CC, arts. 34, 78 e 455 da CLT, e lei 4.591 de 1964) que, se não estudadas e corretamente observadas, podem acarretar uma série de prejuízos para a empresa (CHOMA,2007).

Neste sentido, a adoção de ferramentas específicas e sua utilização nos processos relativos à gestão de contratos de serviços é de suma relevância, pois, quando geridos de forma eficaz e preventiva, agregam valor às demais atividades da empresa, aumentam sua competitividade no mercado e a elevam a um novo patamar social e econômico.

Habitualmente, é o setor jurídico das empresas o responsável pelos cuidados na elaboração e revisão dos contratos com fornecedores. Ocorre que, de modo geral, o conceito de jurídico estratégico ainda não é uma realidade para a grande maioria das empresas, dentro ou fora do ramo da construção civil. Muitas vezes, o setor jurídico da empresa atua de forma reativa (seja de forma litigiosa ou não) ao invés de proativa, isto é, apenas reage aos problemas identificados ao longo do curso de execução dos contratos.

Quando tal situação é transportada para o âmbito da construção civil, o problema torna-se ainda mais grave, uma vez que uma falha no contrato pode acarretar até mesmo na suspensão das atividades nele previstas, ausência de entrega da obra e grande prejuízo econômico para a contratante.

Isto posto, o desenvolvimento da ferramenta (planilha eletrônica) apresenta-se como medida alternativa para o controle e prevenção dos riscos atinentes à atividade de gestão de contratos.

\section{1 - Gestão de contratos}

Sabe-se que a execução de um empreendimento, no âmbito da construção civil, é um processo que envolve insumos inúmeros e atividades diversas (BALLOU, 2000). Não raro, muitas dessas atividades serão terceirizadas ou subempreitadas, ainda que a empresa construtora disponha de condições técnicas, financeiras e jurídicas para a realização do empreendimento.

Verifica-se, inclusive, a existência de inúmeras empresas especializadas em determinadas atividades ou segmentos muito específicos da construção civil, o que acaba por se tornar um atrativo para empresas que buscam a concretização de uma obra ou empreendimento, uma vez que a delegação de determinadas tarefas para um parceiro 
especializado significa, muitas vezes, garantia de boa execução do serviço e redução de custos.

A mencionada delegação de atividades ocorre por intermédio de um contrato, que será o instrumento por meio do qual estarão registradas todos os deveres e obrigações entre as partes envolvidas (FRANCISCO, 1999).

As definições de contrato são múltiplas, e seu significado é bastante variável de acordo com a ótica em que é observado (se pelo âmbito do Direito ou da Engenharia, por exemplo). Para Meirelles (2005), contrato é "todo acordo de vontades, firmado livremente pelas partes, para criar obrigações e direitos recíprocos". Em seu aspecto mais específico, os contratos de construção, são:

Todo ajuste para execução de obra certa e determinada, sob direção e responsabilidade do construtor, pessoa física ou jurídica legalmente habilitada a construir, que se incumbe dos trabalhos especificados no projeto, mediante as condições avençadas com o proprietário ou comitente. (MEIRELLES, 2005).

Formalizadas as vontades expressas pela via do instrumento do contrato, sua finalidade passa a ser a regulação de uma atividade qualquer, como a prestação de um serviço, o fornecimento de um bem, ou a execução de uma obra completa, na qual são fornecidos materiais, equipamentos, mão-de-obra, dentre outros insumos (LIMMER, 1997).

Cabe salientar que decisões judiciais que extrapolam os limites do direito a ser aplicado caracterizam-se como ativistas e importam em descaracterização da função jurisdicional em detrimento das funções inerentes aos Poderes Legislativo e Executivo (PAVANI, 2013).

Assim, uma empreitada, seja de pequena ou média complexidade, está rodeada de contratos das mais variadas naturezas e com as mais diferentes partes e finalidades, o que exige uma atenção redobrada do gestor de suprimentos acerca da boa confecção e execução desses instrumentos (NAKANO, 2020). Neste sentido, gestão de contratos, por ser um segmento específico da gestão de suprimentos, também deve ser feita de forma estratégica, a fim de se garantir a eficácia dos contratos firmados.

Em que pese a multiplicidade de modalidades de contrato, o presente trabalho concentra-se apenas no estudo dos contratos de empreitada, suas características, objetos, e demais aspectos legais.

\section{2 - Contratos por empreitada}

Os contratos de construção de obras de engenharia classificam-se em dois subgrupos, quais sejam, os contratos de empreitada e os contratos de construção por administração (GOMES, 2008).

Em função da delimitação do tema de estudo, somente os contratos de empreitada serão abordados no presente trabalho. O contrato de empreitada é aquele em que uma parte se obriga a fazer uma obra determinada para a outra parte, mediante retribuição acertada previamente ou proporcional ao trabalho executado (GONZÁLES,1997).

Os sujeitos da relação contratual são o empreiteiro, indivíduo ou empresa que contrata com outro indivíduo ou organização (o dono-da-obra) para a realização de obras de construção, e o dono-da-obra, indivíduo ou organização que é proprietário da obra ou empreendimento objeto do contrato de empreitada (GOMES, 2008).
A obra, por sua vez, nas palavras de Miranda Carvalho (1953, p. 17), pode ser compreendida como " $[\ldots]$ o resultado de um trabalho, sendo o efeito de tudo que se tenha gerado com a interferência da ação humana". Ainda, pode ser classificada como corpórea (tangível) ou incorpórea (intangível), móvel ou imóvel (MIRANDA CARVALHO, 1953).

O contrato de empreitada pode ser classificado, ainda, segundo divisões quanto ao objeto e aos modos de fixação de preços. Tais especificações definem obrigações assumidas pelo empreiteiro e pelo dono da obra, com os respectivos limites de responsabilidade (GONZÁLES, 1997).

Quanto ao objeto, a contratação da empreitada pode ser realizada de forma global ou por mão-de-obra (PINHEIRO, 2018). Na forma global, o empreiteiro, além de contrair as obrigações referentes à execução das tarefas necessárias para conclusão da obra, é responsável pelo fornecimento dos materiais necessários e contratação da mão-de-obra. A empreitada global também é popularmente conhecida como empreitada de material ou empreitada mista, haja visto que o empreiteiro assume obrigações de dar e fazer (GONZÁLES, 1997).

Já na empreitada de mão-de-obra, como o próprio nome sugere, os contratos têm como objeto apenas o fornecimento de mão-de-obra especializada, não fornecendo quaisquer materiais ou tecnologias. Também conhecida como empreitada de lavor, a obrigação assumida pelo empreiteiro é tão somente a obrigação de fazer. (GONZÁLES, 1997).

Em ambos os casos, ainda que a responsabilidade sobre a mão-de-obra seja do empreiteiro, é dever da empresa construtora ou incorporadora, dona da obra, a fiscalização sobre o cumprimento da legislação trabalhista pertinente, sob pena de incorrer em modalidade de terceirização ilícita e, eventualmente, arcar com o passivo trabalhista decorrente da má-execução da empreitada, conforme disposição do $\$ 5^{\circ}$ do art. $5^{\circ}$ da Lei n. 13.429/17.

A responsabilidade, como o próprio nome sugere, refere-se à extensão das obrigações do contratante sobre o objeto do contrato. Para Noronha (2012) "a responsabilidade civil é sempre uma obrigação de reparar danos. Estes podem ser causados à pessoa ou ao patrimônio de outrem, ou danos causados a interesses coletivos ou transindividuais".

A responsabilidade também pode ser subjetiva ou objetiva, diferenciando-se apenas em relação à existência do elemento culpa (por negligência, imprudência ou imperícia) quando constatados o dano e o nexo causal. (NORONHA, 2012). Em casos de responsabilização subsidiária, a extensão do dever de reparação do dano é limitada à comprovação da culpa (responsabilidade subjetiva). No caso da responsabilização solidária, a responsabilidade é objetiva, decorrente da comprovação do dano e do nexo causal (nos casos de contratos de empreitada, a mera tomada de serviços).

Note-se, contudo, que a responsabilidade é, via-deregra, subsidiária, e não é extensível para os casos em que o dono da obra é pessoa física ou empresa não integrante do setor da construção civil (inteligência da Orientação Jurisprudencial n. 191 do Tribunal Superior do Trabalho). Há casos, no entanto, em que o julgamento é pela responsabilização solidária da tomadora dos serviços, por 
aplicação do raciocínio da responsabilidade objetiva (DELGADO, 2014).

Gomes (2008) ainda esclarece que a subempreitada (que é a cessão parcial da obra aos cuidados de um terceiro) constitui um segmento dos contratos de empreitada, porém com um caráter ainda mais especializado. O empreiteiro, com o consentimento prévio ou tácito do dono da obra, pode contratar outro empreiteiro para execução de parte da obra a responsabilidade técnica, contudo, não é transferida nesse processo. O mesmo autor considera que os contratos de empreitada também podem ser agrupados de acordo com a fixação dos preços, que podem ser a preço fixo, por medição de serviços ou preço de custo.

Segundo Gonzáles (1997), na empreitada a preço fixo, o "[...] preço é fixado antecipadamente e pelo todo (à forfait), mediante estudos e orçamentos que o empreiteiro apresenta ao contratante e que instruem ou compõem o contrato. A vantagem desta forma é a certeza do preço final, garantindo ao contratante o conhecimento de seus dispêndios". Diniz (1992) e Rondina (1993) distinguem a empreitada a preço fixo entre os critérios absoluto e relativo - na primeira hipótese, são inadmitidos quaisquer reajustes ou alterações de valor, ao passo que na segunda hipótese estas são permitidas

$\mathrm{Na}$ empreitada com medição de serviços, ao invés do estabelecimento de um custo total da empreitada, há a definição prévia de preços unitários, os quais serão mensurados conforme o andamento da execução da obra. Assim, até a conclusão da empreitada, não é possível ter certeza sobre os custos totais envolvidos na obra. (GONZÁLES).

Finalmente, a empreitada por preço de custo, de modo semelhante ao anterior, também estipula o pagamento por preços unitários, mas sem os definir previamente. Neste caso, os custos da obra são apenas estimativas, e podem variar bastante em épocas de aquecimento ou desaquecimento do mercado da construção civil.

Um orçamento prévio pode ser realizado, mas servirá apenas como piso, não sendo rigorosamente seguido. Assim, o pagamento do empreiteiro consistirá apenas na cobrança de um percentual, fixo ou variável de acordo com as etapas da obra, sobre os valores de materiais e mão-de-obra empreendidos na execução (GONZÁLES, 1997).

Por todo o exposto, os contratos de empreitada devem ser tratados com cautela, uma vez que envolvem investimentos consistentes, riscos contínuos e possiblidade de responsabilização do dono-da-obra por danos gerados pela empreiteira.

\section{MÉTODO DE PESQUISA}

O procedimento usado para elaboração da ferramenta seguiu a lógica ilustrada na Figura 1.

$\mathrm{Na}$ primeira etapa a metodologia constituiu no levantamento bibliográfico para o suporte do trabalho e na coleta de dados de jurisprudência dos tribunais. Os dados coletados foram agrupados de acordo com sua natureza, para então, passarem para a próxima etapa do método, qual seja, a qualificação do material. O protocolo de coleta e análise de dados foi subdividido em três etapas de procedimentos, quais sejam: 1) coleta de dados; 2) qualificação dos dados coletados e 3) aplicação dos dados coletados para o desenvolvimento da ferramenta.
Figura 1 - Fluxograma de procedimento

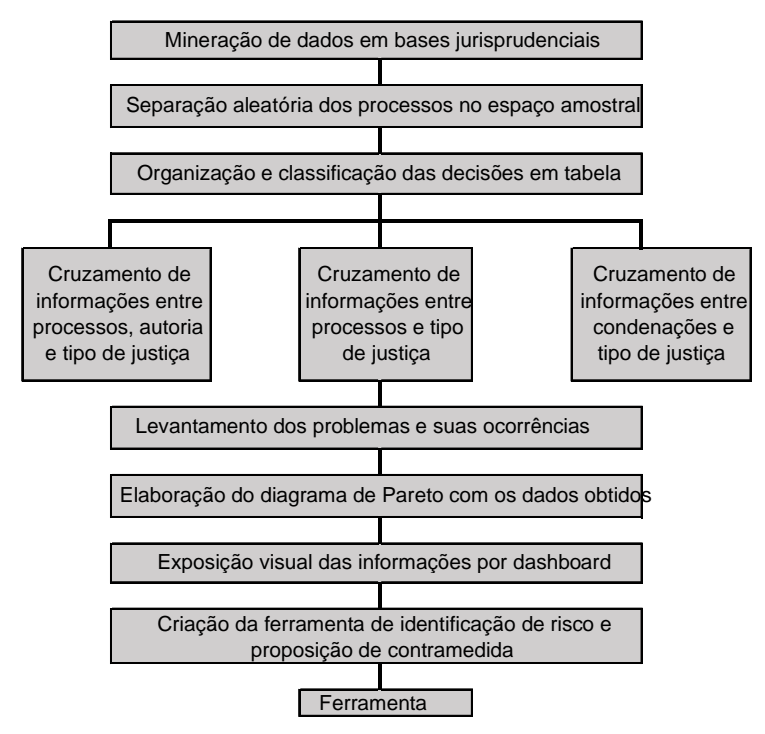

Fonte: Os autores (2020).

Já no segmento jurisprudencial, foram levantadas e agrupadas 100 decisões de segundo grau prolatadas nas Justiças Estadual (somente matéria cível) e Trabalhista do Estado do Paraná, relativas a contratos de empreitada, independentemente da natureza da parte que o ajuizou (se empreiteira ou dono-da-obra).

A escolha da coleta e análise das decisões prolatadas em segundo grau se deve ao fato de que estas não podem sofrer novo julgamento de mérito, tornando-se, portanto, a última instância em que as partes podem discutir os fatos da lide. Os Tribunais Superiores (TST, STF e STJ) não analisam fatos, apenas o direito e o processo.

De outra parte, a circunscrição da coleta de dados aos processos em trâmite na Justiça Estadual (comum) e Justiça do Trabalho foi escolhida em razão de serem os principais foros de litígio dos contratos de empreitada e também por disporem de ampla e organizada base de dados (pesquisa jurisprudencial). Além disso, a quantidade de processos que se encaixam nos critérios supramencionados compõe um número razoável para fixação da população base da definição amostral.

Tais decisões foram escolhidas de modo aleatório e serão detidamente analisadas para levantamento das seguintes informações: 1) $n^{\circ}$ do processo; 2) ano de prolação da decisão; 3) qualidade da parte autora; 4) qualidade da parte ré; 5) natureza dos pedidos e 6) condenação (sem valores liquidados).

Aqui cabe uma ressalva em relação ao número 100 como fixador do espaço amostral. Nas buscas por "contrato de empreitada" nos Tribunais Paranaenses (trabalhista e estadual - comarcas de matéria cível), em instância superior, dentro do lapso temporal de dois anos, o retorno de resultados é de uma população de 1.189 (mil cento e oitenta e nove) processos na seara trabalhista e 288 (duzentos e oitenta e oito) processos na esfera estadual cível, resultando em uma população-base de 1.477 (mil quatrocentos e setenta e sete) processos relativos a contratos de empreitada.

Esta população engloba todas os resultados de pesquisa por "contrato de empreitada" disponíveis nas bases de dados dos tribunais mencionados. Isso inclui não só as decisões meritórias (aquelas que efetivamente julgam o mérito do caso e importam em condenação), como também aquelas 
decisões ditas sanatórias ou de andamento, que prezam pela simples movimentação do processo ou esclarecimento de obscuridades ou contradições.

Foi utilizada, então, a seguinte fórmula para definição da amostra:

$$
n=Z^{2} \cdot p \cdot(1-p) / e^{2}
$$

Onde: n: amostra calculada, Z: variável normal, $\mathrm{p}$ : real probabilidade do evento, e: erro amostral

Fonte: Oshoa, (2013)

\section{RESULTADOS}

A ferramenta construída possui 4 abas: tabela de processos, tabela de dados, dashboard e riscos e contramedidas. Na planilha tabela de processos (Figura 2) foram inseridos os 100 processos da amostra sendo considerados somente as relações entre a relação de demandas em contratos de empreitada com a natureza da Justiça.

Figura 2 - Imagem de parte da planilha com informações dos processos da amostra selecionada

\begin{tabular}{|c|c|c|c|}
\hline $\mathrm{B}$ & c & D & $\mathrm{E}$ \\
\hline $\mathrm{N}^{*}$ processo & And $=$ & Requerente - & Requerido \\
\hline $000018-31.2019 .5 .09 .066$ Justiça do Trabalhe & 2020 & Empregado & $\begin{array}{l}\text { Empresa Pública (dono-da- } \\
\text { obra): Empreiteira } \\
\text { terceirizada }\end{array}$ \\
\hline $00032-88.2018 .5 .09 .00$ EJustiça do Trabalhe & 2020 & Empreiteiro autônomc & Empreiteira \\
\hline 000040-50.2019.5.09.00 Justiça do Trabalhe & 2020 & Empregado & $\begin{array}{c}\text { Empresa Pública (dono-da- } \\
\text { obra): Empreiteira } \\
\text { terceirizada }\end{array}$ \\
\hline 1000045-04.2017.8.16.015 Justį̧a Comum & 2020 & Empreiteira & Município (dono-da-obra) \\
\hline 000057-44.2019.5.09.03CJustiça do Trabalhe & 2020 & Empregado & $\begin{array}{c}\text { Empresa Pública (dono-da- } \\
\text { obra): Empreiteira } \\
\text { terceirizada }\end{array}$ \\
\hline 1000102-39.2018.5.09.067 Justiça do Trabalhe & 2020 & Empreiteiro autônomc & Empreiteiras terceirizadas \\
\hline 1000105-28.2019.5.09.013 Justiça do Trabalhe & 2020 & Empregado & $\begin{array}{c}\text { Dono-da-obra; Empreiteira } \\
\text { terceirizada }\end{array}$ \\
\hline $000127-75.2019 .5 .09 .065$ Justiça do Trabalhe & 2020 & Empregado & $\begin{array}{l}\text { Empresa Pública (dono-da- } \\
\text { obra): Empreiteira } \\
\text { terceirizada }\end{array}$ \\
\hline 0000203-41.2017.5.09.001 Justiça do Trabalhe & 2020 & Empregado & $\begin{array}{l}\text { Empresa Pública (dono-da- } \\
\text { obra): Empreiteira } \\
\text { terceirizada }\end{array}$ \\
\hline $000227-67.2018 .5 .09 .00$ iJustiça do Trabalhe & 2020 & Empreiteiro autônomc & $\begin{array}{c}\text { Dono-da-obra: Empreteira } \\
\text { terceirizada }\end{array}$ \\
\hline 000253-62.2018.5.09.065 Justiça do Trabalhe & 2019 & Empreiteiro autônomc & $\begin{array}{r}\text { Dono-da-obi } \\
\text { tercei }\end{array}$ \\
\hline 000283-74.2016.5.09.065 Justiça do Traballhe & 2020 & Empreiteiro autônomc & $\begin{array}{c}\text { Dono-da-obra; Empreteira } \\
\text { terceirizada }\end{array}$ \\
\hline 1000289-06.2017.5.09.001Justiça do Trabalhe & 2020 & Empreiteiro autônomc & Dono-da-obra (PF) \\
\hline 0000292-11.2019.5.09.059 Justiça do Trabalhe & 2019 & Empreiteiro autônoms & $\begin{array}{c}\text { Empresa Pública (dono-da- } \\
\text { obra): Empreiteira } \\
\text { terceirizada }\end{array}$ \\
\hline 000305-92.2017.5.09.065 Justiça do Trabalhe & 2020 & Empregado & $\begin{array}{l}\text { Dono-da-obra; Empreteira } \\
\text { terceirizada }\end{array}$ \\
\hline 0000325-35.2018.5.09.031 Justiça do Trabalhe & 2020 & Empregado & $\begin{array}{l}\text { Autarquia (dono-da-obra); } \\
\text { Empreiteira terceirizada }\end{array}$ \\
\hline 1000330-14.2018.5.09.067 Justiça do Traballhr & 2020 & Empregado & $\begin{array}{l}\text { Empreiteira (dono-da- } \\
\text { obra); Empreteira }\end{array}$ \\
\hline Tabela de processos & & lados & Dashboard \\
\hline
\end{tabular}

Fonte: Os autores (2020)

Verificou-se que, de acordo com os dados coletados e aplicando o Princípio de Pareto (GARVIN, 1992), mais de $80 \%$ dos casos de litígio em contratos de empreitada são discutidos em sede da Justiça do Trabalho (Figura 3).
Figura 3 - Resumo dos dados da ferramenta

\begin{tabular}{|c|c|c|c|}
\hline Contagen de $\mathrm{S}^{\prime}$ prucesso & Justica & & \\
\hline Requerente & - Jussica Counar & Justica bo Trahs lho & Isal Genal \\
\hline Devo-da-obra & 26 & & 26 \\
\hline Enpregado & & 24 & 24 \\
\hline Enpreiten & 14 & & 14 \\
\hline Enpretero autiosmo & 9 & 24 & 33 \\
\hline Seguradora & I & & I \\
\hline Socio da enpreiteina & 1 & 1 & 2 \\
\hline Iobl Genal & 51 & 49 & 100 \\
\hline
\end{tabular}

\begin{tabular}{|c|c|c|c|c|}
\hline Nanareza do petibo & Fide Ocorrân. & Acursthdo & - 96 Tnitiriós - & 96 Acunulado \\
\hline Rescisio de cooturto & 3 & 53 & \begin{tabular}{l|l}
17535 \\
\end{tabular} & $1755 \%$ \\
\hline $\begin{array}{l}\text { Velbus decoerentes ife } \\
\text { couctate }\end{array}$ & 30 & 105 & $16,69 \%$ & $34,11 \%$ \\
\hline Danos morais & +2 & 145 & $139 \%$ & 4015 \\
\hline Danos matefias & 36 & 181 & $119 \%$ & $5993 \%$ \\
\hline Finculo de ancrege & 35 & 216 & 11,696 & $7152 \%$ \\
\hline Responsakluraçầo & I & 215 & 1936 & 30,465 \\
\hline 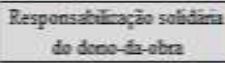 & 12 & 255 & $40 \%$ & $8+44_{4}$ \\
\hline Iucros cessantes & 9 & 264 & $3 \%$ & $87,42 \%$ \\
\hline Razususte de valores & 9 & 273 & 3,046 & $92,40 \%$ \\
\hline Thoos acultos & 7 & 280 & $23 \% 6$ & 92725 \\
\hline Bloco ecunónica & 7 & 187 & 2336 & $95,03 \%$ \\
\hline Bestiniçio de valieres & 4 & 291 & $1,3 \%$ & $9636 \mathrm{hi}$ \\
\hline $\begin{array}{l}\text { Respens. subsibinia da } \\
\text { enpr terceminada }\end{array}$ & 3 & 294 & 1046 & $9735 \%$ \\
\hline $\begin{array}{l}\text { Desconsideraçäo da } \\
\text { personalidade jonitca }\end{array}$ & 1 & 295 & $23 \%$ & $97.98 \%$ \\
\hline Devoluyâa do amas & 1 & 296 & $0.3 \%$ & $98,01 \%$ \\
\hline
\end{tabular}

Tabela de processos Tabelas de dados Dashboard | Riscos e contramedi Fonte: Os autores (2020).

Percebeu-se que a Justiça do trabalho é mais comumente escolhido em razão de, geralmente, não implicar em custas judiciais ou honorários para o demandante (empregado ou autônomo), pelos benefícios da gratuidade da justiça. De outra parte, também é possível o raciocínio de que a empreitada é, muitas vezes, um serviço pessoalizado, em especial se o empreiteiro for autônomo. Nessa situação, não raro o trabalho na empreitada confunde-se com o trabalho típico de emprego - o que deverá ser apreciado pela própria Justiça do Trabalho, definindo ou não sua competência no caso (GONÇALVEZ, 2010).

Analisando-se os dados obtidos percebeu-se que não há demandantes empreiteiros ou donos-de-obra na Justiça do Trabalho. Não obstante, foi identificada uma única situação da amostra em que o demandante era sócio da empreiteira, sob alegação de possuir participação inexpressiva na sociedade e trabalhar como empregado de fato. No mesmo sentido, não foram verificados empregados autores de demanda na Justiça Estadual, uma vez que, por determinação constitucional, é a Justiça do Trabalho que detém a competência para julgamento nessas situações.

A aplicação do diagrama de Pareto sobre as diversas ocorrências de litígio permitiu a identificação das principais - aquelas que concentram o maior número de demandas e condenações - e que, portanto, devem constituir foco de atenção do gestor de contratos.

Ainda, para a análise do diagrama de Pareto, os pedidos foram ser dispostos em ordem decrescente (de acordo com o número de ocorrências), para, então, realizar o cálculo dos percentuais unitários e acumulados. Ao se aplicar o método mencionado sobre os dados coletados ao longo desta pesquisa, foram obtidos os resultados elencados na tabela 1 .

Nota-se também que as empreiteiras estão em quarta posição no ranking de judicialização de contratos.

A análise dos dados obtidos, a curva $\mathrm{ABC}$ (ou diagrama de Pareto) demonstrou que $71,52 \%$ dos casos de litigância repousam sobre cinco pedidos: 1) rescisão contratual; 2) verbas 
trabalhistas decorrentes de contrato de trabalho; 3) danos morais; 4) danos materiais e 5) vínculo de emprego correspondem à maior parte dos litígios analisados. Esses cinco pedidos, agrupados, formam o bloco de "Risco de Passivo" ou seja, grupo em que as matérias supracitadas implicam em maior risco de litígio e condenação.

Os fundamentos para tais pedidos são os mais variados, e podem também ter diversas origens. Para uma melhor compreensão do assunto, os pedidos foram dispostos em tabela, com a disposição em lista dos fundamentos que motivaram aqueles pedidos, conforme retirado dos processos fixados no espaço amostral.

Tabela 1 - Cruzamento dos dados para análise de diagrama de Pareto

\begin{tabular}{|c|c|c|c|c|}
\hline Natureza do pedido & \begin{tabular}{|c|}
$\begin{array}{c}\mathbf{N}^{\circ} \mathrm{de} \\
\text { Ocorrências }\end{array}$ \\
\end{tabular} & Acumulado & \begin{tabular}{|c|}
$\%$ \\
Unitário \\
\end{tabular} & $\begin{array}{c}\% \\
\text { Acumulado } \\
\end{array}$ \\
\hline Rescisão de contrato & 53 & 53 & $17,5 \%$ & $17,55 \%$ \\
\hline Verbas decorrentes de contrato & 50 & 103 & $16,6 \%$ & $34,11 \%$ \\
\hline Danos morais & 42 & 145 & $13,9 \%$ & $48,01 \%$ \\
\hline Danos materiais & 36 & 181 & $11,9 \%$ & $59,93 \%$ \\
\hline Vínculo de emprego & 35 & 216 & $11,6 \%$ & $71,52 \%$ \\
\hline $\begin{array}{c}\text { Responsabilização subsidiária } \\
\text { do dono-da-obra }\end{array}$ & 27 & 243 & $8,9 \%$ & $80,46 \%$ \\
\hline $\begin{array}{c}\text { Responsabilização solidária do } \\
\text { dono-da-obra }\end{array}$ & 12 & 255 & $4,0 \%$ & $84,44 \%$ \\
\hline Lucros cessantes & 9 & 264 & $3,0 \%$ & $87,42 \%$ \\
\hline Reajuste de valores & 9 & 273 & $3,0 \%$ & $90,40 \%$ \\
\hline Vícios ocultos & 7 & 280 & $2,3 \%$ & $92,72 \%$ \\
\hline Bloco econômico & 7 & 287 & $2,3 \%$ & $95,03 \%$ \\
\hline Restituição de valores & 4 & 291 & $1,3 \%$ & $96,36 \%$ \\
\hline $\begin{array}{c}\text { Respons. subsidiária da empr. } \\
\text { Terceirizada }\end{array}$ & 3 & 294 & $1,0 \%$ & $97,35 \%$ \\
\hline $\begin{array}{c}\text { Desconsideração da } \\
\text { personalidade jurídica }\end{array}$ & 1 & 295 & $0,3 \%$ & $97,68 \%$ \\
\hline Devolução do arras & 1 & 296 & $0,3 \%$ & $98,01 \%$ \\
\hline Não incidência de ICMS & 1 & 297 & $0,3 \%$ & $98,34 \%$ \\
\hline Diferenças de reajuste & 1 & 298 & $0,3 \%$ & $98,68 \%$ \\
\hline Bloqueio de imóvel & 1 & 299 & $0,3 \%$ & $99,01 \%$ \\
\hline $\begin{array}{l}\text { Competência da JT para } \\
\text { julgamento }\end{array}$ & 1 & 300 & $0,3 \%$ & $99,34 \%$ \\
\hline Unicidade contratual & 1 & 301 & $0,3 \%$ & $99,67 \%$ \\
\hline Cobrança de honorários & 1 & 302 & $0,3 \%$ & $100,00 \%$ \\
\hline
\end{tabular}

Fonte: Os autores (2020).

Prosseguindo com a análise dos dados obtidos, a curva $\mathrm{ABC}$ (ou diagrama de Pareto) demonstrou que 71,52\% (setenta e um vírgula cinquenta e dois por cento) dos casos de litigância repousam sobre cinco pedidos: 1) rescisão contratual; 2) verbas trabalhistas decorrentes de contrato de trabalho; 3) danos morais; 4) danos materiais e 5) vínculo de emprego correspondem à maior parte dos litígios analisados. Esses cinco pedidos, agrupados, formam o bloco de "Risco de Passivo".

Ressalte-se que estas solicitações são apenas algumas das mais variadas causas de pedir possíveis. Nada impede que a tabela seja constantemente alimentada com novas informações, para que a acurácia da ferramenta melhore conforme os dados são ampliados e atualizados.

Dando prosseguimento, as motivações (ou causas de pedir) indicadas como originárias dos pedidos são dispostas no Quadro 1, desta vez, atrelada à uma contramedida específica para a situação em análise. A ferramenta orienta também a escolha de um tipo de "Risco de Passivo", o qual forneceu algumas das hipóteses de origem de conflito. Avaliada a probabilidade de ocorrência do conflito de acordo com o perfil de atuação da empresa, a ferramenta disponibilizou um conjunto de orientações sobre o procedimento de prevenção e redução dos riscos envolvidos.
Quadro 1 - Causas dos cinco principais pedidos de rescisão dos contratos

\begin{tabular}{|c|c|c|c|c|}
\hline $\begin{array}{l}\text { Rescisão de } \\
\text { contrato }\end{array}$ & $\begin{array}{c}\text { Verbas } \\
\text { decorrentes } \\
\text { de contrato }\end{array}$ & $\begin{array}{l}\text { Danos } \\
\text { morais }\end{array}$ & $\begin{array}{c}\text { Danos } \\
\text { materiais }\end{array}$ & $\begin{array}{l}\text { Vínculo de } \\
\text { emprego }\end{array}$ \\
\hline $\begin{array}{c}\text { Descumprimento } \\
\text { de cláusulas } \\
\text { contratuais }\end{array}$ & Moradia & Litigância & $\begin{array}{c}\text { Retenção de } \\
\text { valores } \\
\text { previdenciários }\end{array}$ & $\begin{array}{l}\text { Inexistência de } \\
\text { MEI }\end{array}$ \\
\hline $\begin{array}{l}\text { Cobrança de } \\
\text { multa indevida }\end{array}$ & Alimentação & $\begin{array}{c}\text { Atraso na } \\
\text { entrega }\end{array}$ & $\begin{array}{c}\text { Retenção de } \\
\text { valores } \\
\text { tributários }\end{array}$ & Subordinação \\
\hline Incapacidade civil & Transporte & $\begin{array}{l}\text { Negociação } \\
\text { prejudicada }\end{array}$ & $\begin{array}{c}\text { Custos com } \\
\text { materiais }\end{array}$ & $\begin{array}{c}\text { Ausência de } \\
\text { contrato }\end{array}$ \\
\hline $\begin{array}{c}\text { Problemas } \\
\text { financeiros da } \\
\text { empreiteira }\end{array}$ & EPI & $\begin{array}{l}\text { Má-fé das } \\
\text { partes }\end{array}$ & $\begin{array}{l}\text { Custos com } \\
\text { mão-de-obra }\end{array}$ & Contratos verbais \\
\hline $\begin{array}{l}\text { Problemas } \\
\text { financeiros do } \\
\text { dono-da-obra }\end{array}$ & $\begin{array}{l}\text { Reembolso por } \\
\text { depreciação de } \\
\text { ferramentas }\end{array}$ & $\begin{array}{l}\text { Execução } \\
\text { da obra com } \\
\text { muitas } \\
\text { falhas }\end{array}$ & $\begin{array}{l}\text { Lucros } \\
\text { cessantes por } \\
\text { atraso de } \\
\text { entrega de obra }\end{array}$ & $\begin{array}{c}\text { Responsabilidade } \\
\text { objetiva (tomada } \\
\text { dos serviços) }\end{array}$ \\
\hline $\begin{array}{c}\text { Falhas na } \\
\text { execução da obra }\end{array}$ & $\begin{array}{l}\text { Acidente de } \\
\text { trabalho }\end{array}$ & $\begin{array}{c}\text { Paralisação } \\
\text { das } \\
\text { atividades } \\
\text { sem aviso } \\
\text { prévio } \\
\end{array}$ & $\begin{array}{l}\text { Custos com } \\
\text { cobertura de } \\
\text { sinistro }\end{array}$ & $\begin{array}{c}\text { Multas por } \\
\text { auditorias do MPT }\end{array}$ \\
\hline $\begin{array}{c}\text { Falhas na } \\
\text { execução da obra }\end{array}$ & $\begin{array}{l}\text { Salário in } \\
\text { natura }\end{array}$ & $\begin{array}{c}\text { Trabalho } \\
\text { em } \\
\text { condições } \\
\text { insalubres } \\
\text { ou perigosas }\end{array}$ & $\begin{array}{l}\text { Custos com } \\
\text { erros de cálculo } \\
\text { de reajuste }\end{array}$ & Trabalho habitual \\
\hline Vícios ocultos & Horas extras & $\begin{array}{c}\text { Acidente de } \\
\text { trabalho }\end{array}$ & & $\begin{array}{c}\text { Trabalho } \\
\text { pessoalizado }\end{array}$ \\
\hline $\begin{array}{c}\text { Paralisação de } \\
\text { atividades }\end{array}$ & $\begin{array}{l}\begin{array}{c}\text { Prontidão e } \\
\text { sobreaviso }\end{array} \\
\end{array}$ & & & $\begin{array}{c}\text { Terceirização } \\
\text { ilícita }\end{array}$ \\
\hline Atraso na entrega & $\begin{array}{l}\text { Insalubridade e } \\
\text { periculosidade }\end{array}$ & & & \\
\hline $\begin{array}{c}\text { Falhas na } \\
\text { medição de } \\
\text { complexidade da } \\
\text { obra } \\
\end{array}$ & $\begin{array}{l}\text { Verbas } \\
\text { rescisórias }\end{array}$ & & & \\
\hline Sinistros & FGTS & & & \\
\hline $\begin{array}{c}\text { Utilização de } \\
\text { mão-de-obra } \\
\text { irregular }\end{array}$ & $\begin{array}{c}\text { Verbas de } \\
\text { natureza } \\
\text { salarial } \\
\end{array}$ & & & \\
\hline
\end{tabular}

Fonte: Os autores (2020).

Finalizadas as tabelas, uma combinação entre as funções de lista suspensa, PROCH e PROCV do Excel permite ao usuário a identificação rápida e automatizada do risco de passivo, sua origem e a contramedida respectiva (Figura 2).

Figura 2 - Imagem da aba "Riscos e contramedidas"

\begin{tabular}{|c|c|c|c|c|}
\hline $\begin{array}{l}\text { Rescisão de } \\
\text { contrato }\end{array}$ & \begin{tabular}{|c|} 
Verbas \\
decorrentes \\
de contrato
\end{tabular} & Danos morais & $\begin{array}{c}\text { Danos } \\
\text { materiais }\end{array}$ & $\begin{array}{l}\text { Vínculo de } \\
\text { emprego }\end{array}$ \\
\hline $\begin{array}{l}\text { Descumprimento } \\
\text { de cláusulas } \\
\text { contratuais } \\
\end{array}$ & Moradia & Litigância & $\begin{array}{c}\text { Retenção de } \\
\text { valores } \\
\text { previdenciários } \\
\end{array}$ & Inexistência de MEI \\
\hline $\begin{array}{c}\text { Cobrança de multa } \\
\text { indevida }\end{array}$ & Alimentação & Atraso na entrega & $\begin{array}{c}\text { Retenção de } \\
\text { valores tributários }\end{array}$ & Subordinação \\
\hline Incapacidade civil & Transporte & $\begin{array}{l}\text { Negociação } \\
\text { prejudicada }\end{array}$ & $\begin{array}{l}\text { Custos com } \\
\text { materiais }\end{array}$ & $\begin{array}{l}\text { Ausência de } \\
\text { contrato }\end{array}$ \\
\hline $\begin{array}{c}\text { Problemas } \\
\text { financeiros da } \\
\text { empreiteira }\end{array}$ & EPI & Má-fé das partes & $\begin{array}{c}\text { Custos com mão- } \\
\text { de-obra }\end{array}$ & Contratos verbais \\
\hline $\begin{array}{c}\text { Problemas } \\
\text { financeiros do } \\
\text { dono-da-obra }\end{array}$ & $\begin{array}{c}\text { Reembolso por } \\
\text { depreciação de } \\
\text { ferramentas }\end{array}$ & $\begin{array}{c}\text { Execução da obra } \\
\text { com muitas } \\
\text { falhas }\end{array}$ & $\begin{array}{c}\text { Lucros cessantes } \\
\text { por atraso de } \\
\text { entrega de obra }\end{array}$ & $\begin{array}{c}\text { Responsabilidade } \\
\text { objetiva (tomada dos } \\
\text { serviços) }\end{array}$ \\
\hline $\begin{array}{c}\text { Falhas na execução } \\
\text { da obra }\end{array}$ & $\begin{array}{l}\text { Acidente de } \\
\text { trabalho }\end{array}$ & \begin{tabular}{|c|} 
Paralisação \\
atividades sem \\
aviso prévio \\
\end{tabular} & \begin{tabular}{|c|}
$\begin{array}{c}\text { Custos com } \\
\text { cobertura de } \\
\text { sinistro }\end{array}$ \\
\end{tabular} & $\begin{array}{c}\text { Multas por } \\
\text { auditorias do MPT }\end{array}$ \\
\hline $\begin{array}{c}\text { Falhas na execução } \\
\text { da obra }\end{array}$ & $\begin{array}{l}\text { Salário in } \\
\text { natura }\end{array}$ & $\begin{array}{c}\text { Trabalho em } \\
\text { condições } \\
\text { insalubres ou } \\
\text { perigosas }\end{array}$ & $\begin{array}{l}\text { Custos com erros } \\
\text { de cálculo de } \\
\text { reajuste }\end{array}$ & Trabalho habitual \\
\hline Vícios ocultos & Horas extras & $\begin{array}{l}\text { Acidente de } \\
\text { trabalho }\end{array}$ & & $\begin{array}{c}\text { Trabalho } \\
\text { pessoalizado }\end{array}$ \\
\hline $\begin{array}{c}\text { Paralisação de } \\
\text { atividades }\end{array}$ & $\begin{array}{c}\text { Prontidão e } \\
\text { sobreaviso }\end{array}$ & & & $\begin{array}{c}\text { Terceirização } \\
\text { ilícita }\end{array}$ \\
\hline
\end{tabular}

Fonte: Os autores (2020). 


\section{CONCLUSÃO}

Conforme visto ao longo do desenvolvimento do presente artigo, a ferramenta proposta sugere a conciliação da gestão de contratos com a gestão de riscos. Definido o público-alvo e o objeto de estudo, quais sejam, respectivamente, empresas do setor produtivo da construção civil e contratos de empreitada, foi estruturado um modelo de ferramenta em que, com base em decisões judiciais sobre a matéria, orienta, de forma automatizada, melhorias aos processos que envolvem redução de riscos.

A ferramenta ora desenvolvida segue um procedimento simples, que pode ser ajustado conforme o melhor interesse do usuário. A base de dados utilizada pode variar de acordo com as reais necessidades da empresa. Do mesmo modo, é uma ferramenta que permite atualização e ampliação constantes, uma vez que novos dados podem ser inseridos sem prejuízo da leitura das informações ali já contidas.

Isso significa dizer que a ferramenta também pode ser ajustada para outros setores produtivos e outros tipos de contrato. No entanto, caberá ao desenvolvedor os ajustes necessários, em especial no que se refere à leitura dos riscos e indicação de contramedidas.

Outrossim, sugere-se a aplicação da ferramenta pelo setor jurídico da empresa, como medida de otimização de recursos. Isso porque a ferramenta, haja vista que constrói sua base de dados diretamente da análise dos litígios, e não só da lei pura, age diretamente no combate e prevenção dos riscos oriundos de passivo judicial, cujos impactos econômicos são, via-de-regra, bastante relevantes para a saúde econômica de uma empresa.

Assim, é possível que a utilização da ferramenta, além de otimizar o processo de avaliação do risco em gestão de contratos, incremente a blindagem legal desses mesmos contratos, vez que antecipa situações já vistas em casos análogos no judiciário. Ainda, há que se ressaltar que a ferramenta proposta é flexível e dinâmica, também comportando a possibilidade de inclusão de novas ferramentas em sua composição.

Finalmente, percebe-se que a leitura do dashboard fornece ao usuário uma série de informações acerca dos motivos que induzem a discussão de contratos de empreitada em litígio. Muitas delas, inclusive, referem-se a problemas que poderiam ser evitados desde o início, por meio de uma simples qualificação de fornecedores.

Por exemplo, no processo de contratação de subempreiteiras, é interessante avaliar se a empresa configura na lista de devedores trabalhistas ou se já sofreu autuações por trabalho irregular por parte do Ministério Público. Isso porque foi constatado que tal contratação pode incorrer em modalidade de terceirização ilícita, o que implica em responsabilização da empreiteira contratante e do dono-da-obra.

Neste sentido, é possível afirmar que o modelo aqui proposto também pode servir como parâmetro de análise, classificação e qualificação desses fornecedores, porque fornece dados relevantes acerca dos elementos gerados de risco de passivo contratual, cabendo ao intérprete desses dados a transformação deles em critérios para seleção de fornecedores.

\section{REFERÊNCIAS}

BALLOU, R. H. Logística empresarial: transporte, administração de materiais e distribuição física. São Paulo: Atlas, 2000.

CHOMA, A. A. Como gerenciar contratos com empreiteiros: manual de gestão de empreiteiros na construção civil. 2.ed. São Paulo: Pini, 2007.

DINIZ, M. H. Curso de direito civil brasileiro. V.3: Teoria das obrigações contratuais e extracontratuais. 7ed. São Paulo: Saraiva, 1992.

FRANCISCO, B. C. Fatores Relevantes Para a Gestão de Empreendimentos de Construção Civil. 110p. Dissertação (Mestrado em Engenharia Civil) - Universidade Federal Fluminense. Niterói, 1999.

GARVIN, D. A. Gerenciando a qualidade - a gestão estratégica e competitiva. Rio de Janeiro: Qualitymark, 1992.

GOMES, O. Contratos. 26.ed. Rio de Janeiro: Forense, 2008.

GONÇALVES, C. R. Direito Civil Brasileiro. 7.ed. v. 03. São Paulo: Saraiva, 2010.

GONZÁLES, M. A. S. A documentação como requisito para o incremento da qualidade: os contratos de construção por empreitada e por administração. In: II Encontro Nacional de Engenharia de Produção. Anais eletrônicos do ENEGEP 1997. Gramado, 1997. Disponível em:

http://www.abepro.org.br/biblioteca/ENEGEP1997_T3208. PDF>. Acesso em 01 abr 2020.

LIMMER, C. V. Planejamento, orçamentação e controle de projetos e obras. Rio de Janeiro: LTC. 1997.

MEIRELLES, H. L. Direito de construir. $9^{\circ}$ ed. São Paulo: Malheiros, 2005.

MIRANDA CARVALHO, E.V. Contrato de empreitada. Rio de Janeiro: Freitas Bastos, 1953.

NAKANO, Y. Globalização, competitividade e novas regras do mercado mundial. Revista de economia política. Vol. 14, n. 4. São Paulo: 1994. Disponível em: <http://www.rep.org.br/PDF/56-1.PDF>. Acesso em: 01 abr 2020.

NORONHA, Fernando. Direito das obrigações: fundamentos do direito das obrigações - introdução à responsabilidade civil. V. I. São Paulo: Saraiva, 2012.

OSHOA, C. Qual é o tamanho da amostra que eu preciso. 2013. disponível em https://www.netquest.com/blog/br/blog/br/qual-e-otamanho-de-amostra-que-preciso. Acesso em 29 set 2020.

PAVANI, D.E. Ativismo judicial em matéria de saúde considerações acerca das atribuições dos entes federativos. Revista Sodebras [on line]. v. 8, n. 89, Maio/ 2013, p.3946. ISSN 1809-3957. Disponível em: , <http://www.sodebras.com.br/edicoes/N89.pdf> Acesso em 05 abr 2020.

PINHEIRO, A. C. da F. B. Gestão de contratos na construção civil. São Paulo: Érica, 2018. 
RONDINA, H. Contrato de obra publica y privada. Santa Fe (Argentina): Universidad Nacional del Litoral, 1993.

SERRA, S. M. B. O gestor de contratos. 2010. Disponível em http://construcaomercado.pini.com.br/negociosincorporacao-construcao/105/artigo299375-1. aspx. Acesso em 02 de dezembro de 2019.

\section{COPYRIGHT}

Os autores são responsáveis pelo material apresentado neste artigo.

Submetido em: 04/09/2020

Aprovado em: 04/10/2020 


\title{
Revista SODEBRAS - Volume 15 \\ $\mathrm{N}^{\circ} 178$ - OUTUBRO/ 2020
}

\section{OTIMIZAÇÃO DE FROTA DE EMPILHADEIRA: UM ESTUDO DE CASO}

\author{
FORKLIFT FLEET OPTIMIZATION: A CASE STUDY
}

\author{
MARIANA OG GALLO ESTEVES ${ }^{1}$; NILO ANTONIO DE SOUZA SAMPAIO ${ }^{2}$; \\ JOSÉ GLÊNIO MEDEIROS DE BARROS ${ }^{2}$; ANTONIO HENRIQUES DE ARAUJO JUNIOR ${ }^{2}$ \\ 1 - DISCENTES DA UERJ-FAT; 2 - DOCENTES DA UERJ-FAT \\ marioggallo@hotmail.comnilo.samp@terra.com.br; glenio.barros@gmail.com; \\ anthenriques2001@yahoo.com.br
}

\begin{abstract}
Resumo - Esse artigo apresenta um estudo de Manufatura Enxuta realizado no processo de fabricação de pneus, numa fábrica situada em Itatiaia - RJ, com objetivo de otimizar a frota e reduzir os custos envolvendo aluguel de empilhadeira. Para guiar esse estudo foi usada a metodologia DMAIC (Definir, Medir, Analisar, Melhorar e Controlar). Os resultados encontraram uma otimização de cinco empilhadeiras, com redução nos custos associados por ano.
\end{abstract}

Palavras-chave: Manufatura Enxuta. Otimização. Metodologia DMAIC.

\begin{abstract}
This paper presents a Manufacturing study carried out in the tire production process, in a factory located in Itatiaia - RJ, in order to optimize the fleet and reduce costs using forklift rental. For guidance this study, the DMAIC methodology (Define, Measure, Analyze, Improve, and Control) was used. The results found an optimization of five forklifts, with a reduction in the associated costs per year.
\end{abstract}

Keywords: Lean Manufacturing. Optimization. DMAIC Methodology.

\section{INTRODUÇÃO}

No atual mercado globalizado, as organizações devem estar conscientes que não podem desacelerar seus empenhos na busca pela melhoria contínua nos seus processos. Assim, é preciso otimizar os fluxos envolvidos nesses. As organizações têm dispendido consideráveis esforços e recursos no sentido de promover a melhoria contínua do processo de manufatura e assim garantir uma sólida posição no seu mercado.

Dentre os diversos fatores críticos de sucesso que as empresas devem considerar, destaca-se a busca por padrões cada vez mais elevados de produtividade e qualidade. Fatores como qualidade e confiabilidade do produto, agilidade no atendimento às exigências do mercado e flexibilidade são considerados como as novas dimensões de sucesso empresarial (SLACK; CHAMBERS; JOHNSTON, 2009), (DA SILVA, et al., 2017).

O DMAIC é um ciclo de aprimoramento orientado a dados, projetado para ser aplicado a processos buscando eliminar falhas ou ineficiências. O objetivo da aplicação do DMAIC é melhorar, otimizar ou estabilizar os processos existentes. Possui cinco fases distintas, onde cada uma delas disponibiliza ao usuário uma série de ferramentas com o objetivo de alcançar o sucesso do projeto e gerar histórico em relação ao comportamento dos processos. São elas: $1^{a}$ fase:
Definir (Define) - definir os objetivos de melhoria do processo que sejam consistentes com as demandas do cliente e a estratégia da empresa; $2^{a}$ fase: Medir (Measure) - coletar os dados necessários do processo para dimensionar o tamanho do problema. São as medições base no processo atual para comparação futura; $3^{\mathrm{a}}$ fase: Analisar (Analyse) necessário o uso de software estatístico para a realização de cálculos e gráficos que permitam conhecer as nãoconformidades do processo e suas variações; $4^{\mathrm{a}}$ fase: Melhorar (Improve) - identificar e implementar as melhorias no processo já existente; $5^{\mathrm{a}}$ fase: Controlar (Control) controlar o processo, realizar a transição para produção e posteriormente, medir continuamente o processo para garantir que as variações são corrigidas antes de se transformarem em defeitos (SILVA, M.D.B, 2020).

$\mathrm{O}$ artigo é estruturado a seguir: na segunda seção apresenta os objetivos, na terceira a metodologia e na quarta os resultados e discussão. Na última seção são descritas as conclusões e os trabalhos futuros.

O diagrama de Pareto é uma representação gráfica que permite priorizar a resolução de problemas através de um princípio chamado 80-20. O conceito de que, na maioria das situações, $80 \%$ das consequências é resultado de $20 \%$ das causas foi fruto de um estudo de Vilfredo Pareto sobre distribuição de renda, onde ele descobriu que $80 \%$ da riqueza estava concentrada em cerca de $20 \%$ da população. Utilizado para organizar os problemas em categorias de acordo com a frequência, podendo ser muito útil para tratar não conformidades, identificar pontos de melhoria e definir planos de ação que devem ser priorizados. O Diagrama de Pareto apresenta um gráfico de barras que permite priorizar os problemas a serem resolvidos, por meio das frequências de cada uma das ocorrências, da maior para a menor, é possível visualizar que, na maioria das vezes, há muitos problemas menores diante de outros mais graves e significativos, que representam maiores perdas para a organização (SAMPAIO, N et al. ,2020).

\section{OBJETIVOS}

Tendo como visão da usina "Conquistar participação no mercado, sendo referência na redução do custo de fabricação", a Fábrica de Pneus adotou como estratégia para melhorar o desempenho industrial de maneira global, alcançar o melhor equilíbrio para o "triângulo de desempenho", Figura 1, assegurar o atendimento 
(fornecimento) ao cliente, otimizando a utilização dos ativos e estabelecendo competitividade, como segue:

Figura 1 - Triângulo de Desempenho

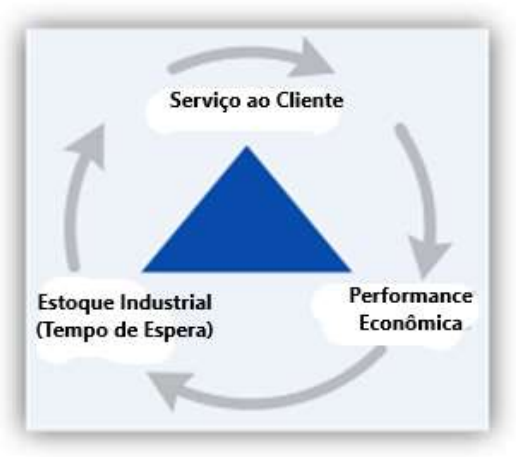

Fonte: Própria Autora.

Esse triângulo possui um dos vértices que foca o desempenho econômico. Isso se mostra coerente devido ao cenário de mercado na América do Sul, onde a Fábrica de Pneus enfrenta uma concorrência pesada em relação aos preços.

Dentro da decomposição do custo de fabricação do pneu, o custo gasto com contrato de empilhadeira tem relevância significativa, o que justifica a escolha do tema do estudo.

O objetivo do estudo é de reduzir em $15 \%$ o parque de empilhadeiras da fábrica, utilizando a ferramenta DMAIC, que atualmente é composto por 31 máquinas, alcançando um total de 27, sem que o desempenho da usina seja impactado. As quatro empilhadeiras representam um custo de $408 \mathrm{KBRL}$ no contrato anual.

Nem todas as empilhadeiras são utilizadas em tempo pleno (todas as equipes).

\section{METODOLOGIA}

A metodologia empregada neste trabalho foi o estudo de caso, com uma abordagem qualitativa. Este estudo está focado na aplicação da Metodologia Enxuta para redução dos desperdícios, fazer com que a melhoria parta da equipe. Além disso, tenha como principal resultado a satisfação do cliente e a excelência operacional.

Orientado dela visão da empresa de competitividade no mercado, é necessário introduzir abordagens de aplicações de ferramentas para a melhoria dos processos, como a metodologia DMAIC (PEREZ-WILSON, 1999; ECKES, 2011; PANDE et al., 2001; WERKEMA, 2013; CARVALHO; PALADINI, 2005). Esse método combinado com a produção enxuta, comum na literatura, onde podemos encontrar descrições da interação entre manufatura enxuta e seis sigma (STEPHEN, 2004), como também em melhoria de processos na saúde (PROUDLOVE et al., 2008). Essa metodologia tem aplicabilidade não só em grandes empresas, como também em pequenos processos e/ou negócios (KUMAR et al., 2006), entre outros.

Para tal, o projeto foi guiado pela metodologia DMAIC, a qual é exemplificada pela Figura 2.
Figura 2 - Metodologia DMAIC (refazer a figura com textos em português para manter a coerência com outras figuras)

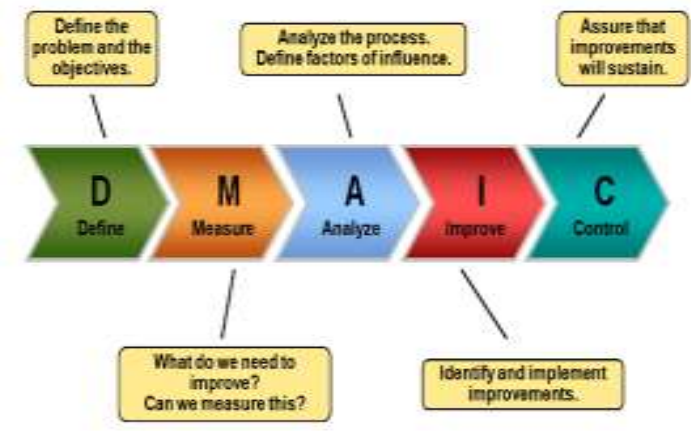

Fonte: Própria Autora.

A metodologia DMAIC se originou com o intuito de reduzir variações, focado principalmente em processos fabris. O DMAIC tem processos de resoluções de problemas que se assemelham ao PDCA (DE MAST; LOKERBOOL, 2012).

Dentro das fases do DMAIC, temos a possibilidade de usar diversas ferramentas que auxiliam na estruturação e sistematização do método, auxiliando assim na redução de taxas e variabilidade de falhas e defeitos nos processos e/ou produtos (SANTOS, 2006; CARVALHO; PALADINI, 2005). Em Matos (2003) mostra como um dos principais fatores para o sucesso do projeto, a utilização da ferramenta CTQ (Critical to Quality - Características Críticas para a Qualidade). Essa ferramenta está na etapa de caracterização do problema, onde podemos entender melhor, a seguir:

D: Na primeira etapa do projeto, denominada como Definir, espera-se entender as expectativas do cliente, qual o problema a ser resolvido e o escopo do projeto. Se aprofundar no problema para identificar quais são os pontos críticos no processo responsáveis pela geração dos defeitos, e maus resultados, como por exemplo: altos custos de mão de obra, alto custo com contratos de serviços, reclamações de clientes, baixa qualidade dos produtos, erros de processo, alto nível de recusa, dentre outros (CARVALHO; PALADINI, 2005). É nessa etapa que é realizado o Project Charter, com a validação do Sponsor, que é a documentação que permite a realização projeto. (WERKEMA, 2013). É necessário detalhar nesse contrato a razão que motivou o projeto, os recursos necessários, a equipe núcleo, limite de escopo, clientes e cronograma (LIN et al., 2013).

M: Na segunda etapa do projeto, denominada como Medir, espera-se observar, medir e identificar os problemas. É nesta etapa que deve acontecer o refinamento das informações e dados para concentrar nas causas do problema (WERKEMA, 2013). Mapeiam-se os dados históricos e/ou desenvolvendo o formato do sistema de medição para assim ser possível gerar análises e identificar as variáveis de saída (MATOS, 2003). É essencial o bom plano de coleta de dados, pois ela servirá de base para validar e quantificar o problema, orientando a priorização das decisões sobre os critérios que serão adotados (LIN et al., 2013).

A: Na terceira etapa do projeto, denominada como Analisar, espera-se encontrar a causa raiz e priorizar o plano de ação. Nesta etapa realiza-se a análise das variáveis que afetam o processo, para ser possível encontrar as causas do problema para serem aprofundados em detalhes e identificados as atividades críticas do problema (LIN et al., 2013). Também se identifica nessa etapa, os gaps entre o desempenho real e o planejado (SANTOS, 2006). 
I: Na quarta etapa do projeto, denominada como Implementar, espera-se identificar e testar as soluções. É nessa fase que se determina como será a intervenção para a redução dos níveis de defeito, ou o novo método adequado para a resolução do problema. Segundo Santos (2006), garantir a melhoria do processo pode estar associada a uma solução capaz de prevenir e/ou eliminar as ocorrências dos problemas. Também com base na etapa anterior, é feito a priorização das ideias fundamentadas nas causas identificadas (WERKEMA, 2013). Podemos utilizar algumas ferramentas nessa etapa, tais como: DOE, FMEA Brainstorming, 5W2H (SATOLO et al., 2009; WERKEMA, 2013).

C: Na quinta etapa do projeto, denominada como Controlar, busca alcançar as melhorias para que o ganho do projeto seja perene. Para que seja mantido as alterações e soluções feitas na etapa anterior, é necessário desenvolver uma maneira de controlar a mudança, para assegurar que ela será mantida, pode-se desenvolver uma carta controle, um novo método de modo operatório padrão, sistemas de auditorias e o monitoramento do desempenho (MATOS, 2003).

\section{RESULTADOS E DISCUSSÃO}

Definir: O projeto foi demandado pelo Chefe de Fabricação, sua demanda teve a seguinte voz: "Ser capaz de absorver 2 empilhadeiras do projeto de aumento de capacidade produtiva da usina, e otimizar mais 3 empilhadeiras do parque combinando postos e/ou atividades."

Com base na VOC (voz do cliente), criou-se a equipe projeto, responsável pela confecção do SIPOC (Documento de controle para Clientes) permitindo identificar os pontos de influência no processo (fornecedores, entradas, saídas e clientes) e serviu de base para a continuidade do projeto, através da cadeia de valor.

O principal resultado dessa etapa foi identificar os pontos relevantes do processo de cada setor de produção bem como suas particularidades.

Cada empilhadeira tem no campo processo um perímetro diferente, nessa etapa, a equipe conseguiu delimitar a área de atuação de cada empilhadeira.

Medir: Foi realizado um brainstorming com toda equipe da engenharia, para identificar as principais oportunidades de combinação de atividades dentro da usina, e a criação da VSM (mapeamento do fluxo de valor), Figura 3:

Figura 3 - Mapeamento do Fluxo (VSM)

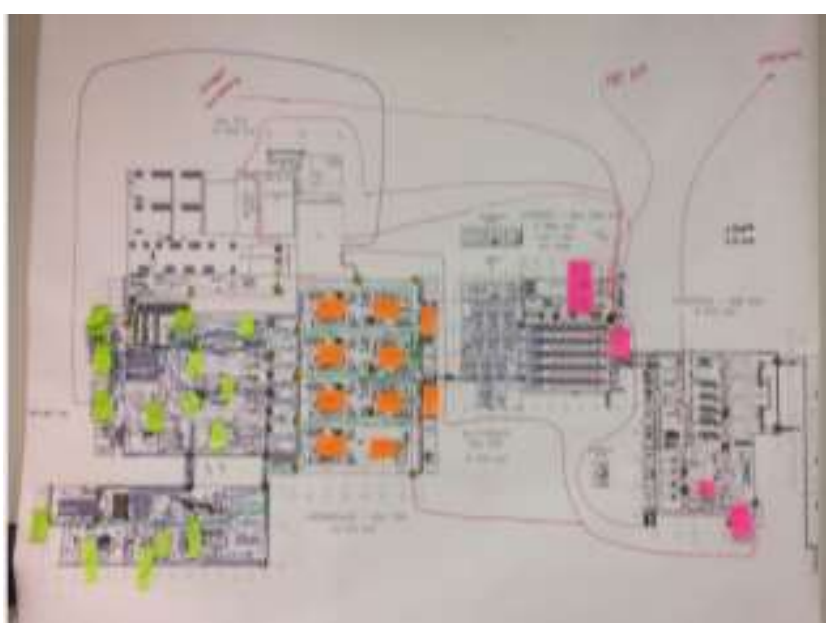

Fonte: Própria Autora.
Com o mapeamento das empilhadeiras, Figura 4, e a primeira estimativa de ocupação das empilhadeiras vista na Tabela 1, foi possível criar um comparativo por setor $\mathrm{x}$ quantidade de empilhadeiras e um quadro de priorização das empilhadeiras a serem analisadas:

Figura 4 - Divisão das empilhadeiras por setor fabril

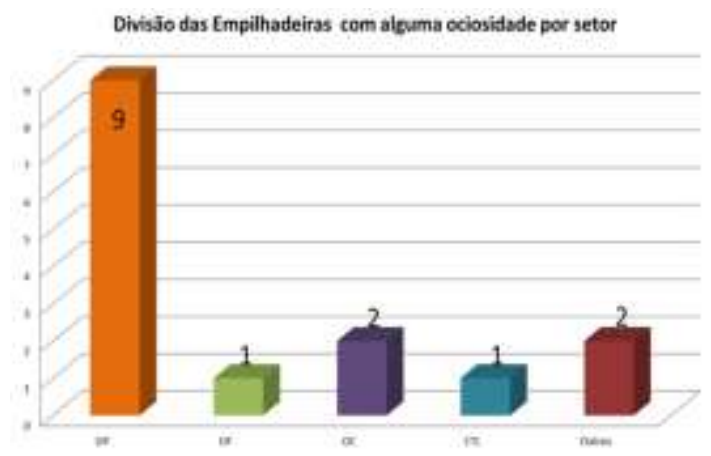

Fonte: Própria Autora.

Tabela 1 - Proposta de combinação das empilhadeiras a serem analisadas

\begin{tabular}{|c|c|}
\hline Foco Green Belt & Ferramenta \\
\hline AEM + NSE & Rlesăzado \\
\hline Reserva OF & Analsssdo \\
\hline $\begin{array}{l}\text { Fefendiagem + } \\
\text { gesep Fris }\end{array}$ & $\propto$ \\
\hline $\mathrm{N}+\mathrm{NC}$ & $\begin{array}{c}\mathrm{OC}+\text { Histórico } \\
\text { horimette }\end{array}$ \\
\hline $\begin{array}{c}\text { Ferthamento de } \\
\text { pakte }\end{array}$ & oC \\
\hline Noco + Rem & $o c$ \\
\hline$F M U+$ NS3 & $O C+$ Ansisn \\
\hline$C \pi+$ Gsrantia & $O C+$ Aniline \\
\hline
\end{tabular}

Priorizacto

Fonte: Fonte Própria.

Analisar: Inicialmente, foi feita uma análise da carga das empilhadeiras através do horímetro. Esse sistema permite medir a quantidade de horas que a máquina ficou operando em um dado espaço de tempo.

Figura 5 - Pareto das ocupações das empilhadeiras

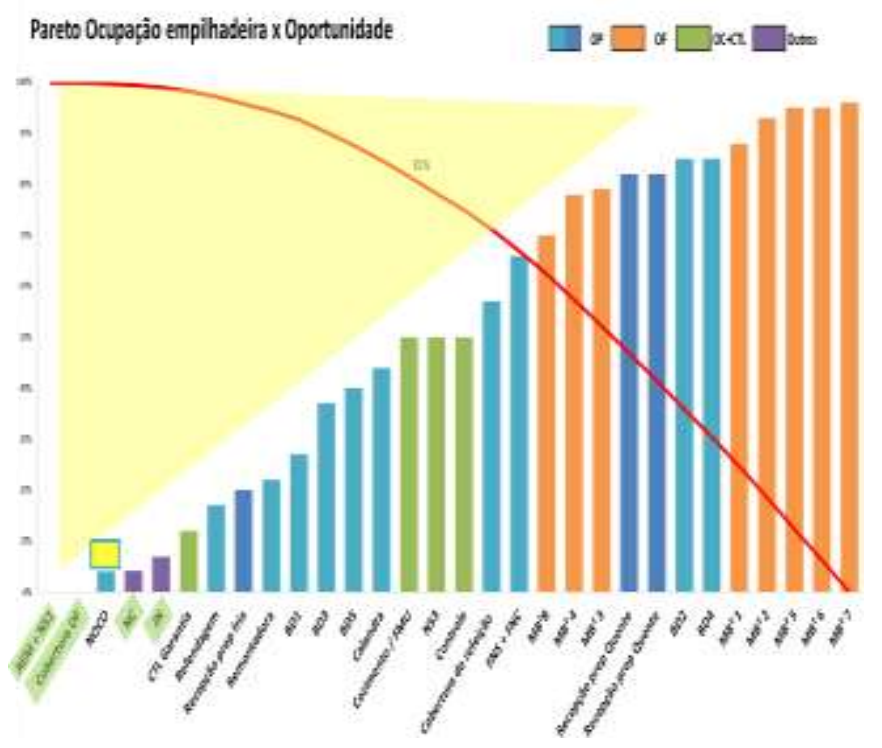

Fonte: Própria Autora. 
O Pareto ordena as empilhadeiras pela porcentagem de ociosidade no dia, e identifica através das cores sua posição no layout da fábrica, sendo uma informação relevante para as possíveis combinações de atividades, detalhes Figura 5.

Com os dados, a equipe decidiu que uma empilhadeira poderia ser retirada como quick win, uma vez que, ela não aparecia com horas relevantes no horímetro, pois sua utilização era de empilhadeira reserva, sem atividade definida. Essa empilhadeira tinha uma baixa ocupação e não ofereciam riscos ao fluxo.

Com base no Pareto, foi possível focar nas empilhadeiras que rodavam o menor tempo do dia, e priorizar a combinação de atividades.

Implementar: Com base no Pareto, foi possível a combinação das atividades da empilhadeira AEM e NS1, responsável por pesagem de sucata semanalmente e por transporte de peça semanal, respectivamente, como são atividades com os dias definidos, foi possível realocar os dias das atividades, sem que houvesse intercessão de atividades. Além delas foi

A segunda oportunidade detectada foram as empilhadeiras $\mathrm{NC}$ e $\mathrm{JN}$, que trabalhavam no perímetro favorável, foi feito uma análise de ocupação das duas empilhadeiras:

Figura 6 - Divisão da ocupação da empilhadeira ao longo dos dias

Ocupação em horas empilhadaras NC e JN

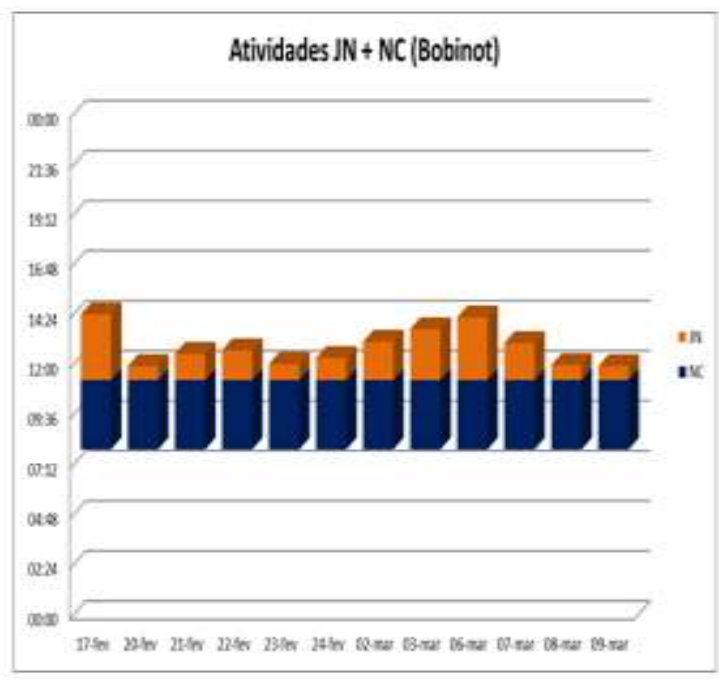

Fonte: Própria Autora

Podemos observar que as duas empilhadeiras funcionam somente em horário administrativo, e que as atividades das duas juntas são comportadas dentro do horário, resultando em uma ocupação de $21 \%$ do dia em média. Sendo assim possível de ser feito a junção das atividades.

A $4^{\mathrm{a}}$ oportunidade identificada foram as empilhadeiras Recepção prep. fria e Refendagem (favorecidas pelo layout). Foi realizado o acompanhamento semanal da utilização da empilhadeira ao longo do horário crítico (administrativo), desconsiderando a ocupação dos operadores que as operavam, visto na Tabela 2 , observou-se o cenário favorávęl para a combinação.
Tabela 2 - Tempo de utilização da empilhadeira por dia acompanhado

\begin{tabular}{|l|c|c|c|c|c|}
\hline \multicolumn{6}{|c|}{ Tempo de utilizaçăo da Empilhadeira (horas) } \\
\hline Dias & 24 -abr & 25 -abr & 26 -abr & 27 -abr & 28 -abr \\
\hline Ret, A-Ret B & 0,99 & 1,05 & 0,81 & 0,85 & 0,38 \\
\hline Recepçäo & 0,27 & 1,84 & 2,15 & 2,51 & 1,76 \\
\hline Totak & 1,26 & 2,89 & 2,96 & 3,36 & 2,14 \\
\hline
\end{tabular}

Ocupacilo en horas empilhadeiras Refendagem e Recepsìn

Controlar: Uma vez que todos os ganhos foram validados, foi feita a renegociação do contrato de empilhadeiras, devolvidas no total de quatro empilhadeiras e definido junto ao gestor dos contratos e o Controle de Gestão o novo standard de 27 empilhadeiras na fábrica.

\section{CONCLUSÃO}

Ao final do projeto, as equipes ficaram satisfeitas com as ações e podemos perceber a satisfação ao se deparar com os resultados alcançados.

Partindo da necessidade de implementação nos processos industriais de melhoria contínua, esse trabalho se baseou na utilização da metodologia DMAIC e a filosofia Lean Manufacturing focado na redução dos desperdícios e produção enxuta, para alcançar o resultado de uma redução de $15 \%$ do parque de empilhadeiras, retratando assim a melhoria buscada no processo.

É de vital importância para as organizações, projetos que reduzem os custos de fabricação, para que cada vez mais possamos ser competitivos e conquistar participação do mercado. Este trabalho serve como referência para futuros trabalhos e aplicações, talvez na área Automotiva e em processos produtivos em geral.

\section{REFERENCIAS}

CARVAlHO, M. M.; PALADINI, E. P. Gestão da Qualidade: teoria e casos. Rio de Janeiro: Elsevier, 2005.

DA SILVA, M. A. B.; DA SILVA, M. M. D.; ROCHA, G. W; ALÉCIO, R. A. Sistema de Produção Enxuta: Analisando os Métodos adotados em uma empresa Metal Mecânica, Revista Sodebras, [on line], v. 12. n.135, mar./2017, p.283287. ISSN 1809-3957. Disponível em: http://www.sodebras.com.br/edicoes/N135.pdf. Acesso em 06 jan.2017.

DE MAST, J.; LOKKERBOL, J. An analysis of the six sigma DMAIC method from the perspective of problem solving. International Journal of Production Economics. 139(2): 604-614, October 2012. DOI: 10.1016/j.ijpe.2012.05.035

ECKES, G. A revolução Seis Sigma: o método que levou a GE e outras empresas a transformar processos em lucro. Rio de Janeiro: Elsevier, 2011.

KUMAR, M.; ANTONY, J.; SINGH, R. K.; TIWARI, M. K.; Perry, D. Implementing the Lean Sigma framework in an Indian SME: a case study. Production Planning and Control. Pages 407-423. Published online: 21 Feb 2007. https://doi.org/10.1080/09537280500483350.

LIN, C.; CHEN, F. F.; WAN, H.; CHEN, Y. M.; KURIGER, G. Continuous improvement of knowledge management 
systems using Six Sigma methodology. Robotics and Computers Integrated Manufacturing, 2013.

MATOS, J. L. Implementação de um projeto de melhorias em um processo de reação química em batelada utilizando o método DMAIC. Dissertação (Mestrado). UFRGS, 2003.

PANDE, P. S.; NEUMAN, R. P.; CAVANAGH, R.R. Estratégia Seis Sigma: Como a GE, a Motorola e outras grandes empresas estão aguçando seu desempenho. Rio de Janeiro: Qualitymark, 2001.

PEREZ-WILSON, M. Seis Sigma: Compreendendo o conceito, as implicações e os desafios. Rio de Janeiro: Qualitymark, 1999

PROUDLOVE, N.; MOXHAM, C.; BOADEN, R. Lessons for lean in healthcare from using Six Sigma in the NHS. Public Money and Management. Ano 2008.

SAMPAIO, N. A. S; SILVA, M. D. B; BARROS, J. G. M; JUNIOR, A. H. A. Emprego de Ferramentas da Qualidade para reduzir o índice de avarias e os custos com seguro logístico de uma automobilística, Sodebrás, 2020 .

SANTOS, A. B. Modelo de referência para estruturar o programa de qualidade Seis Sigma: proposta e avaliação. Tese (Doutorado). UFSCAR, 2006.

SATOLO, E. G.; ANDRIETTA, J. M.; MGUEL, P. A. C.; CALARGE, F. A. Análise da utilização de técnicas e ferramentas no programa Seis Sigma a partir de um levantamento tipo survey. Produção. Ano 2009.

SLACK, N.; Chambers, S.; Johnston, R. Administração da produção. Trad. de F. de Oliveira, F. Alher e H.L. Corrêia. 3. ed. São Paulo: Atlas, 2009

SILVA, M. D. B; SAMPAIO; N. A. S; BARROS, J. G. M; ARAUJO JUNIOR, A. H. Employment of Quality Tools to Reduce the Failure Index and Safe Costs in the Logistic Process of an Automobile. Revista Sodebras [on line], v.15, .n. 170, Fev./2020, p.52-61, ISSN 1809-3957. DOI: https://doi.org/10.29367/issn.1809-3957.15.2020.

STEPHEN, P. Application of DMAIC to integrate Lean Manufacturing and Six Sigma. Thesis Master of Science. Virginia Polytechnic Institute and State University, 2004.

WERKEMA, C. Métodos PDCA e DMAIC e suas ferramentas analíticas. Rio de Janeiro: Elsevier, 2013.

\section{COPYRIGHT}

Direitos autorais: Os autores são os únicos responsáveis pelo material incluído no artigo.

Submetido em: 09/09/2020

Aprovado em: 09/10/2020 


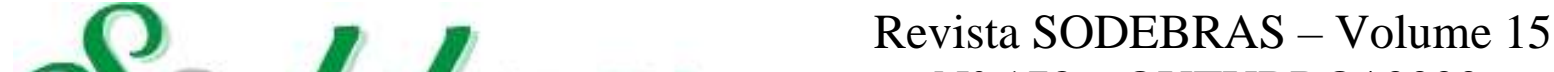 $\mathrm{N}^{\circ} 178$ - OUTUBRO/ 2020 \\ REDUÇÃO DE PERDAS ATRAVÉS DA DIGITALIZAÇÃO DE PROCESSOS NO CONTEXTO DA INDÚSTRIA 4.0
}

\section{WASTE REDUCTION THROUGH DIGITALIZATION OF PROCESSES IN THE CONTEXT OF INDUSTRY 4.0}

\author{
MARCOS RONALDO ALBERTIN ${ }^{1}$; JUSICLEITON SANTOS PEREIRA²; \\ HERÁCLITO LOPES JAGUARIBE PONTES ${ }^{3}$ \\ $1 ; 2 ; 3$ - UNIVERSIDADE FEDERAL DO CEARÁ \\ albertin@ot.ufc.br; jscltn@gmail.com; hjaguaribe@ufc.br
}

\begin{abstract}
Resumo - A indústria 4.0 iniciou uma série de avanços na cadeia produtiva contribuindo para a redução de desperdícios nas organizações, unido espaços físicos a digitais. Frente a isso, o presente estudo apresenta os benefícios obtidos com a redução do tempo operacional por meio da digitalização de um processo em uma usina termelétrica no estado do Ceará. Foram coletados os tempos de execução da atividade com o auxílio de um cronômetro e os dados armazenados em uma planilha eletrônica, antes e após a implementação da melhoria, uso da extensão Google Forms, utilizado para coletar as informações sobre ordens de serviços. Aplicado isso, foi possivel obter ganhos com uma redução de $81,89 \%$ de tempo por execução, como também melhorias nas demais etapas da atividade, como deslocamento, redução de erros e produtividade.
\end{abstract}

Palavras-chave: Indústria 4.0. Digitalização. Produtividade.

Abstract - Industry 4.0 started a series of advances in the production chain contributing to the reduction of waste in organizations, combining physical and digital spaces. In view of this, the present study brings the gains obtained with the reduction of the operational time through the digitization of a process in a thermoelectric plant in the state of Ceará. The execution times of the activity were collected with the aid of a stopwatch and the data stored in an electronic spreadsheet, before and after the implementation of the improvement, use of the Google Forms extension, used to collect information about service orders. Applied this, it was possible to obtain gains with a reduction of $81.89 \%$ of time per execution, as well as improvements in the other stages of the activity, such as displacement, reduction of errors and productivity.

Keywords: Industry 4.0. Digitization. Productivity.

\section{INTRODUÇÃO}

Em 2011, por meio da iniciativa do Industrie 4.0, grupo formado por empresas, academias e o governo alemão, foi lançada a $4^{\mathrm{a}}$ Revolução Industrial, também conhecida como Advanced Manufacturing e Fábricas Digitais, com o intuito de fortalecer a competividade da indústria alemã (HERMANN, 2016).

Com o objetivo de criar valor inteligente, a Industria 4.0 une o ambiente físico ao virtual, integralizando os processos físicos e computacionais, também conhecidos como Sistemas Físicos Cibernéticos. As organizações que aderem a esses conceitos, dar-se o nome de Smart Factories ou Fábricas Inteligentes (LURK, 2019).

A comunicação entre os processos físicos e os computacionais corrobora para a otimização das atividades, uma vez que essa integração é capaz de reduzir o tempo de execução de uma atividade, redução da necessidade de mão de obra, movimentação desnecessária, dentre outros fatores. Tal melhoria contribui de forma direta com a redução de custos dentro da organização (SCHWAB, 2016).

Enquanto de um lado está o conceito de união dos processos físicos e computacionais, do outro, nos deparamos com os desafios da indústria, dentre eles, a eliminação de desperdícios nos seus processos, que por diversas vezes pode ser mínimo, mas quando somado a outros, pode compor uma parcela significativa na organização (ALBERTIN e PONTES, 2016).

A filosofia Lean do Sistema Toyota de Produção pode ser utilizada como método para a eliminação de desperdícios, uma vez que ela possui uma abordagem sobre fazer bem as coisas e melhorar continuamente, visando a redução e/ou eliminação dos desperdícios dentro dos processos (LEAN SUMMIT, 1999 e PICCHI, 2017).

Assim, a digitalização dos processos de controle proporciona reduções significativas como o tempo necessário para executar uma atividade, movimentação, espera, super processamento, bem como a redução de desperdícios de recursos (ELIENÉSIO et. al, 2018)

Frente a esse contexto, este estudo objetiva descrever a aplicação da digitalização dos processos de controle e os benefícios obtidos por meio da implementação dessa prática dentro de uma atividade realizada no setor de Operações de uma usina termelétrica, no Complexo do Pecém, visando a inovação e a tecnologia como meio de otimizar os processos.

O presente artigo é composto por mais 4 sessões, além desta. Na sessão 2 é feita uma revisão da literatura afim de fundamentar os conceitos utilizados para o desenvolvimento do estudo. A sessão 3 descreve a metodologia utilizada no estudo e suas etapas. A sessão 4 é composta pelos resultados obtidos com a aplicação do novo método como solução para o problema identificado. Na sessão 5 temos a conclusão do estudo destacando a importância da aplicação dos conceitos abordados ao longo do estudo. 


\section{FUNDAMENTAÇÃO TEÓRICA}

\section{1 - Indústria 4.0}

A Indústria 4.0 é um modelo baseado nos princípios de otimização da capacidade operacional, virtualização de informações, trabalho descentralizado, orientação a serviços e modularidade (TOTVS, 2020).

Segundo Schwab (2016), a quarta revolução industrial torna-se diferente das anteriores devido a sua principal característica que é as descobertas tecnológicas. Ainda segundo Schwab (2016), a Indústria 4.0 se inclina à substituição da mão de obra humana pela automatizada, dando ênfase nas atividades rotineiras e ainda que essa revolução intensificará um ponto já conhecido, a customização dos produtos e serviços.

\section{2 - O Sistema Toyota de Produção (STP) e a Indústria 4.0}

Segundo Albertin e Pontes (2016), após o fim da $2^{\mathrm{a}}$ Guerra Mundial, por meio dos idealizadores Sakichi Toyoda, seu filho Kiichiro Toyoda (fundador da Toyota Motor Company), Taiichi Ohno e Shingeo Shingo, teve início o Sistema Toyota de Produção (STP). Esse modelo de sistema produtivo trouxe contribuições com princípios, técnicas e ferramentas que auxiliam na melhoria do desempenho dos processos com o objetivo de minimizar custos por meio da eliminação de perdas e elevação da qualidade dos produtos e da satisfação dos clientes.

Ainda segundo Ustundag e Cevickcan (2018), podemos observar a integração das ferramentas do STP e das tecnologias da Indústria 4.0 através de: Células de Manufatura, dispositivos de Poka Yoke, Manutenção Preventiva Total (TPM), Produção com ritmo cadenciado, Kanban, redução de estoque, desenvolvimento de fornecedores, Jidoka e Mapeamento do Fluxo de Valor (MFV).

\section{3 - Digitalização de Processos}

Um dos pontos que a I 4.0 enfatiza é a digitalização de toda a cadeia de valor. A Fábrica Digital tem como um dos seus pilares, a informação em seu formato digital, realizando assim, a integração entre produtos, máquinas e processos.

Segundo a FEIMEC (2019), através do uso de tecnologias como Internet das Coisas (IoT), Big Data e Inteligência Artificial, a cadeia produtiva, em sua totalidade, contemplando desde a produção à entrega ao cliente final, estando ela conectada virtualmente, pode promover uma maior agilidade, produtividade e customização aos produtos.

\section{4 - Otimização de Processos}

De acordo com Leite (2016), o significado de otimização do processo está atrelado a compreender, planejar, mensurar e monitorar as atividades em uma organização, sendo essas automatizadas ou não, afim de obter resultados que estejam em concordância com os objetivos da organização.

Para Leite (2016), a otimização de processos adere as melhores práticas acerca de métodos de trabalho e isso se dá por meio de um documento indicando o método com a atividade deve ser executada, bem como a organização das atividades, isto é, o sequenciamento, uma vez que esse conhecimento torna-se importante pois ajuda a organização a entender seus processos e com isso possam tomar decisões de melhorias para eles.

\section{5 - Sete Desperdícios}

A Toyota listou sete possíveis tipos de desperdícios ou perdas que podem ocorrer em um processo e estes podem ser aplicados em inúmeros tipos de operações diferentes, seja serviço ou manufatura. A contínua redução das 7 perdas é a base da filosofia enxuta.Elas são classificados como (LEAN SUMMIT, 1999; ROTHER, M. \& SHOOK, J, 1998):

\subsection{1 - Superprodução}

A perda por superprodução está ligada ao fato de produzir além da necessidade para o processo seguinte, sendo considerado pela STP, a maior fonte de desperdício dentro de um processo. Cada etapa do processo deve produzir exatamente o que é exigido pelo processo seguinte, de modo que a cadeia de valor atenda à demanda real. A produção em quantidade ou ritmo maior do que o necessário acarreta a utilização desnecessária de recursos, gerando estoques, deslocamentos etc., assim, absorvendo a capacidade que deveria ser utilizada para fazer o que o cliente espera.

\subsection{2 - Tempos de Espera}

Eficiência do homem e eficiência do equipamento são medidas comuns e são utilizadas para avaliar os tempos de espera de máquinas e mão-de-obra, respectivamente. Para o sistema lean o ideal é que todos os processos sigam um fluxo contínuo afim de que entreguem de forma rápida e sem interrupção o produto ao cliente. O desperdício por tempo de espera ocorre quando alguma etapa do processo não está conseguindo atender ao fluxo do processo, ou seja, não está suprindo a necessidade do cliente seguinte resultando na redução da eficiência da próxima etapa.

\subsection{3 - Transporte}

Caracteriza-se pela movimentação de materiais dentro do processo que não agregam valor ao cliente.

\subsection{4-Processo}

São tidas como perdas por processamento ou operações que não agregam valor ao cliente. Estas operações devem ser eliminadas, quando possível.

\subsection{5-Estoque}

Produtos ou serviços são feitos para serem consumidos. É assim que a empresa atende os clientes e tem sua remuneração. Se o que é produzido não é consumido - seja pelo consumidor final, seja pelo processo seguinte numa cadeia produtiva - temos estoques, um dos principais indicadores de um sistema com problemas. O custo financeiro de capital imobilizado e não vendido é o desperdício mais evidente. O estoque esconde vários outros problemas, por exemplo, ao retardar a detecção de defeitos, gerando muitas vezes retrabalhos em grandes lotes (PICCHI, 2017).

\subsection{6 - Movimentação}

De forma similar, movimentos de pessoas sem necessidade também são desperdícios que consomem tempo que não está sendo utilizado para produzir e para criar valor. O ideal é que todo o movimento de um trabalhador seja usado para produzir e para criar valor. Como exemplos da perda por movimentação citam-se a procura de ferramentas dentro de 
uma fábrica e a movimentação de um operador de uma máquina a outra distante (PICCHI, 2017).

\subsection{7-Defeitos}

O ideal, num processo produtivo, é produzir certo "da primeira vez". Desta maneira, não será preciso produzir de novo. O sétimo desperdício identificado por Ohno é um dos que mais ocorrem nas organizações tradicionais: gastar tempo, gente e recursos para refazer, corrigir ou retrabalhar não conformidades. Isso envolve uma série de desperdícios típicos de processos produtivos cheios de falhas: necessidades de inspeções, manejos de refugos etc. Os exemplos são muitos e diversificados. Vão depender do tipo de empresa, do produto, do serviço, mas os desperdícios mais comuns são esses (PICCHI, 2017; SHINGO, Shigeo; SCHAAN, Eduardo, 1996 ).

\section{METODOLOGIA}

O presente estudo foi realizado em uma usina termelétrica situada no Complexo do Pecém, na atividade de lançamento das informações das ordens de serviço executadas no setor de Operações, onde a mesma demandava um tempo elevado para a sua execução.

Esse estudo fez uma associação dos problemas identificados (perdas no processo) com os sete desperdícios listados por Shigeo Shingo (1996), sendo possível a implantação de melhorias com o objetivo de mitiga-los ou eliminá-los.

A atividade utilizada com objeto de estudo se dá em dois momentos: o primeiro é lançamento das informações acerca da realização das ordens de serviços pelos operadores e o segundo é o tratamento desses dados e em seguida o apontamento dessas informações no SAP (ERP utilizado na organização) sendo essa etapa o foco do estudo. Foi possível também a identificação de ganhos nas etapas anteriores a esta.

\section{1 - Cenário anterior à implementação}

Neste cenário, temos o seguinte contexto: o responsável pela execução das ordens de serviço (Operador) era informado por e-mail acerca das ordens que seriam executadas na semana. Com essa informação, ele se dirigia ao local de execução para a realização do serviço, executava a ordem e em seguida, retornava à sala da administração (deslocamento) para lançar as informações em uma planilha eletrônica (Microsof Excel) utilizada como meio para guardar as informações que seriam utilizadas posteriormente. Por diversas vezes, ocorria que, após realizar o serviço, o operador não retornava à sala para apontar as informações, pois surgiam demandas da área que são prioridades sobre esse apontamento. Para o lançamento das informações, se fazia necessário o uso do computador da Sala de Liberação de Permissão de Trabalho, onde, na maioria das vezes o mesmo encontrava-se ocupado por outro colaborador.

Nessa situação, é possível identificarmos outro problema (demora no apontamento das informações na planilha) e com isso, acontecia por diversas vezes o esquecimento e as informações tornavam-se obsoletas. Essas informações são coletadas ao longo da semana (segundafeira à domingo).

Após a coleta das informações, era realizado o tratamento das informações. Esse tratamento consistia em: agrupar as informações das 5 planilhas, copiar as informações de cada uma e transpô-las para uma outra planilha. Em seguida, formatar os dados de acordo com o padrão aceito pelo software de gestão SAP. Nessa etapa era possível identificar outros problemas: a planilha continha muitas informações e se tornava lenta para formatar os dados de acordo com o padrão aceito pelo SAP; o arquivo por diversas vezes corrompia; era necessário copiar as informações para outro modelo de planilha que servia como espelho da transação do SAP (transação - IW44). Ao todo, essa atividade demandava em média três horas para sua realização.

\section{2 - Cenário pós-implementação da digitalização}

No cenário pós-implementação, temos o seguinte contexto: com o objetivo de otimizar essa atividade em sua totalidade foi elaborado um link através da extensão Google Forms (extensão do Google).

Através desse link, o operador tem acesso às informações das ordens a serem realizadas, uma vez que o mesmo contém a relação de todas as ordens a serem executadas na semana.

O formulário é composto pelos campos: relação das ordens, matrícula do executante, data de execução, turno (dia e noite), equipe (A, B, C e D), hora de início, hora de término e observação. Esse formulário eletrônico eliminou a necessidade de impressão (para consultar as ordens planejadas) e o uso de um computador para acesso a planilha eletrônica.

Esse formulário eletrônico é disponibilizado no primeiro dia da semana (segunda-feira - dia determinado pela organização) através de um aplicativo mobile de conversa, com isso, todos tem acesso às informações por meio de smartphone com acesso à internet.

O formulário é simples de ser preenchido e o tempo despendido para isso é em média de 15 a 20s. Outro ponto de destaque é a eliminação do deslocamento do operador até à sala para realizar o apontamento, uma vez que o mesmo pode realizar o apontamento das informações no local onde a ordem é executada.

\section{3 - Coleta de dados}

Diante dos cenários citados, foram coletados os dados (tempo de execução para a última etapa "Lançamento das informações no SAP”).

Foram feitas dez medições ao longo de dez semanas antes da implementação da melhoria e mais dez semanas após a implementação da melhoria. Os tempos foram medidos com o uso de um cronômetro e as informações armazenadas em uma planilha eletrônica (Microsoft Excel).

No cenário anterior à implementação, os tempos foram medidos a partir da etapa de formatação dos dados na planilha que eram alimentados pelos operadores e encerrada após o último lançamento da ordem de serviço no SAP.

Para o cenário pós-implementação (cenário atual) os tempos foram coletados a partir do acesso ao formulário eletrônico no Google Forms e encerrado após o último lançamento da ordem de serviço no SAP.

Após a coleta, foram calculados os tempos médios antes e após a implementação, bem como a redução de tempo sofrida com o novo método implantado.

O primeiro cálculo foi realizado com objetivo de encontrar o tempo médio de execução antes e após a implantação. Pode-se observar a equação utilizada abaixo: 
Tempo Médio $=\frac{\sum \text { Tempos de Execução }}{\text { Quantidade de Amostras }}$

O segundo cálculo foi realizado com o objetivo de encontrar a redução que foi obtida com a melhoria. Pode-se observar a equação utilizada abaixo:

Redução $=\left(\frac{\text { Tempo Médio }(\text { depois })}{\text { Tempo Médio (antes) }}\right) \times 100$

\section{RESULTADOS}

O objeto deste estudo foi a atividade de apontamento de ordens de serviço, com foco na etapa de "Lançamento das informações no SAP", com o intuito de identificar ganhos alcançado com o novo método de realização da coleta das informações acerca das ordens de serviço.

A seguir, temos uma tabela com as amostras dos tempos de realização dessa atividade nos dois cenários.

Tabela 1 - Tempos de execução das atividades

\begin{tabular}{cccc}
\hline Amostras & $\begin{array}{c}\text { Antes da } \\
\text { Melhoria }\end{array}$ & $\begin{array}{c}\text { Depois da } \\
\text { Melhoria }\end{array}$ & Melhoria \\
\hline 1 & $02: 55: 00$ & $00: 33: 00$ & $81,14 \%$ \\
\hline 2 & $03: 24: 00$ & $00: 24: 00$ & $88,24 \%$ \\
\hline 3 & $03: 10: 00$ & $00: 32: 00$ & $83,16 \%$ \\
\hline 4 & $02: 49: 00$ & $00: 35: 00$ & $79,29 \%$ \\
\hline 5 & $02: 45: 00$ & $00: 33: 00$ & $80,00 \%$ \\
\hline 6 & $03: 05: 00$ & $00: 40: 00$ & $78,38 \%$ \\
\hline 7 & $02: 50: 00$ & $00: 37: 00$ & $78,24 \%$ \\
\hline 8 & $03: 15: 00$ & $00: 29: 00$ & $85,13 \%$ \\
\hline 9 & $03: 07: 00$ & $00: 34: 00$ & $81,82 \%$ \\
\hline 10 & $02: 57: 00$ & $00: 32: 00$ & $81,92 \%$ \\
\hline $\begin{array}{c}\text { Tempo } \\
\text { Médio }\end{array}$ & $\mathbf{0 3 : 0 1 : 4 2}$ & $\mathbf{0 0 : 3 2 : 5 4}$ & $\mathbf{8 1 , 8 9 \%}$ \\
\hline \multicolumn{4}{c}{ Fonte: Elaborada pelos autores. } \\
\hline
\end{tabular}

De acordo com os dados acima, é possível observarmos que o tempo médio de execução da atividade no cenário anterior era de aproximadamente 03 horas e que após a implementação do novo método, esse tempo sofreu uma redução significativa para uma média de 33 minutos. Essa redução equivale a um ganho de $81,89 \%$ no tempo de execução dessa atividade. Ela gera impactos positivos no desempenho da área de Manutenção (área responsável pelo processamento das informações de execução das ordens de serviço), pois era necessário aguardar aproximadamente 03 horas pelas informações no sistema, hoje, essa informação leva cerca de 30 minutos para estar acessível no SAP.

$\mathrm{Na}$ tabela a seguir, podemos observar o impacto que essa melhoria trouxe para o tempo de realização da atividade. O tempo despendido antes da melhoria correspondia a cerca de $10.09 \%$ (equivalente a aproximadamente 12 horas) da carga horária mensal do responsável por essa etapa. Com o uso do novo método, esse tempo passou para cerca de $1,83 \%$ (equivalente a 2 horas) de sua carga horária mensal.
Tabela 2 - Tempos de execução das atividades

\begin{tabular}{cc}
\hline Carga Horária Mensal & $120: 00: 00$ \\
\hline $\begin{array}{c}\text { Tempo de Execução Mensal (antes da } \\
\text { melhoria) }\end{array}$ & $12: 06: 28$ \\
\hline $\begin{array}{c}\text { Tempo de Execução Mensal (depois da } \\
\text { melhoria) }\end{array}$ & $02: 11: 36$ \\
\hline \% Tempo de Execução (antes da melhoria) & $10,09 \%$ \\
\hline \% Tempo de Execução (depois da melhoria) & $1,83 \%$ \\
\hline
\end{tabular}

Além dos resultados supracitados, foram evidenciados outros benefícios, como:

- O deslocamento do local de execução da ordem de serviço à sala da administração foi eliminado, pois o operador consegue apontar as informações no smartphone no próprio local onde a ordem foi executada (redução de movimentação);

- Não há mais necessidade de transferir as informações de uma planilha para outra antes de lança-las no SAP, uma vez que o link gera uma única planilha com todas as informações e no padrão aceito pelo SAP (redução de processamento).

Estes resultados confirmam as contribuições das tecnologias da I 4.0 para redução de desperdícios e melhorias dos processos (SANTANA, 2019), e sua importância para o desenvolvimento da indústria brasileira (CNI, 2019). Neste sentido, a engenharia de produção tem um grande desafio e oportunidade no contexto da digitalização e redução de perdas (BARRETO et al., 2019).

\section{CONCLUSÃO}

Este estudo de caso realizado em uma usina termelétrica, possibilitou a identificação e redução de perdas ligadas ao processo de lançamento de ordens de serviço, com também ganhos significativos resultantes do processo de digitalização da atividade que estava sendo realizada. A digitalização do processo de controle por meio do Google Forms mostrou-se capaz de relacionar as práticas implementadas na I 4.0 com as práticas do Sistema Toyota de Produção. A inclusão da tecnologia de digitalização proporcionou a redução de $81,89 \%$ no tempo de realização da atividade, bem com a redução para $1,83 \%$ do tempo total mensal, impactando na diminuição de perdas de processo, tempo de espera, movimentação e não conformidades. Com isso, conclui-se que a adesão da digitalização dos processos de controle tem potencial de melhoria no desempenho da organização, como também se mostra compatível com a redução das perdas do STP. Os resultados obtidos não podem ser generalizados e são limitados aos processos manuais que foram digitalizados.

\section{REFERÊNCIAS}

ALBERTIN, M. R., PONTES, J. L. H. Gestão de processos e técnicas de produção enxuta. Edição 1. Ano Edição 2016. Páginas 159. Editora InterSaberes. Curitiba. Paraná. ISBN 978-85-443-0354-2.

BARRETO, Bernardo Perota; PONTES, Joseane; TREINTA, Fernanda Tavares. A educação 4.0 aplicada à engenharia de produção e as principais temáticas de pesquisa: uma análise de conteúdo a partir da revisão de literatura. Enegep 2019, Santos, SP. 
CNI. Desafios da indústria 4.0 no Brasil. 2016. Disponível em:<https://bucket-gw-cnistatic-cms-si.s3.amazonaws.com/ media/filer_public/d6/cb/d6cbfbba-4d7e-43a0-9784-863650 61a366/desafios_para_industria_40_no_brasil.pdf> Acesso em: 20 abr. 2019.

ELIENÉSIO, Maria Luiza Bufalari; ALBERTIN, Marcos Ronaldo; JAGUARIBE, Heráclito Pontes. Panorama da Indústria 4.0 no Brasil: Principais Tecnologias Utilizadas e os Desafios para sua Implementação. Revista Sodebras [on line]. v. 13, n.148, Abr/2018, p. 147-152. ISSN 1809-3957. Disponível em: <http://www.sodebras.com.br/edicoes/ N148.pdf>. Acesso em 02 set. 2020.

LEITE. Como a otimização de processos pode melhorar a rotina da empresa. 2016. Disponível em: $<$ https://www.artsoftsistemas.com.br/blog/como-aotimizacao-de-processospode-melhorar-a-rotina-daempresa/> Acesso em: 21 abr. 2019.

LEAN SUMMIT. Anais de Conferência sobre Lean Production. Lean Summit. Atlanta, GA, USA (1999).

LURK. Indústria 4.0: tecnologias para otimizar processos. 2019.Disponível em: <https://www.produttivo. com.br/blog/ tecnologia/2019/01/23/industria-4-0-tecnologiasparaotimizar-processos.html> Acesso em: 20 abr. 2019.

PICCHI, Flávio. Entenda os "7 desperdícios" que uma empresa pode ter. 2017. Disponível em:<https://www.lean.org.br/colunas/529/entenda-os$\%$ E2\% 80\%9C7-desperdicios\%E2\%80\%9D-que-umaempresa-pode-ter.aspx> Acesso em 11 mai. 2020.

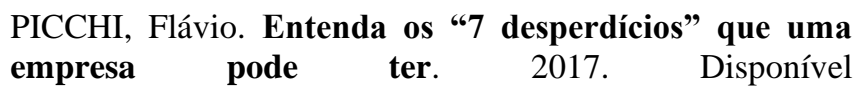
em:<https://www.lean.org.br/colunas/529/entenda-os$\%$ E2\%80\%9C7-desperdicios\%E2\%80\%9D-que-umaempresa-pode-ter.aspx > Acesso em 09 set. 2020.

ROTHER, M. \& SHOOK, J. Learning to See - Value Stream Mapping to Add Value and Eliminate Muda. The Lean Enterprise Institute, MA, USA.1998.

SANTANA, Rodrigo Roberto de; LIMA, Lucas Gomes; OLIVEIRA, Emanuel Teixeira de; NUNES, João Alberto de Souza. Contribuições da indústria 4.0 para otimização de processo: um estudo e caso em uma empresa do ramo alimentício. ENEGEP 2019, Santos, SP.

SHINGO, Shigeo; SCHAAN, Eduardo. O sistema Toyota de produção: do ponto de vista da engenharia de produção. Porto Alegre: Bookman, 1996.

SCHWAB, Klaus. The Fourth Industrial Revolution. Genebra: World Economic Forum, 2016.

TOTVS. A voz da indústria. São Paulo, 17 mar. 2018. Disponível em: < https://avozdaindustria.com.br/indstria-40totvs/entenda-o-que-industria-40-e-quais-so-seusimpactos/>. Acesso em: 14 mai. 2020.

USTUNDAG, A., CEVIKCAN, E. Industry 4.0: Managing The Digital Transformation. Springer Series in Advanced Manufacturing. ISBN 978-3-319-57870-5 (eBook) https://doi.org/10.1007/978-3-319-57870-5. SPRINGER 2018.

\section{COPYRIGHT}

Direitos autorais: Os autores são os únicos responsáveis pelo material incluído no artigo.

Submetido em: 10/09/2020

Aprovado em: 10/10/2020 


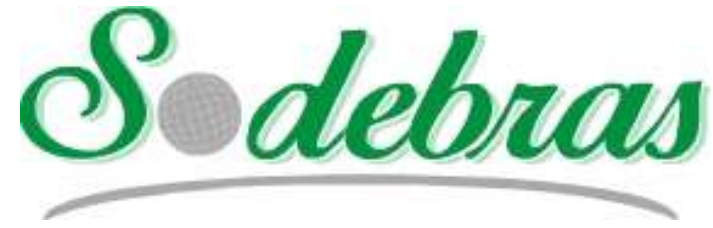

\title{
AVALIAÇÃO DE INDICADORES EMPRESARIAIS ATRAVÉS DA ANÁLISE FATORIAL EXPLORATÓRIA E TEORIA DE RESPOSTA AO ITEM
}

\section{EVALUATION OF BUSINESS INDICATORS USING EXPLORATORY FACTOR ANAL YSIS AND ITEM RESPONSE THEORY}

\author{
MARCOS RONALDO ALBERTIN ${ }^{1}$; MARCOS CHARLES PINHEIRO BALTAZAR ${ }^{2}$; \\ HERÁCLITO LOPES JAGUARIBE PONTES ${ }^{3}$ \\ 1 - UNIVERSIDADE FEDERAL DO CEARÁ; 2 - INSTITUTO FEDERAL DE ALAGOAS; \\ 3 - UNIVERSIDADE FEDERAL DO CEARÁ \\ albertin@ot.ufc.br; marcos.charles@ifal.edu.br; hjaguaribe@ufc.br
}

\begin{abstract}
Resumo - Indicadores são bem explorados para medir o desempenho empresarial, mas há atributos que não podem ser facilmente mensuradas. Este trabalho explorou o comportamento de indicadores empresariais utilizando Análise Fatorial Exploratória e Teoria de Resposta ao Item. A amostra contou com 203 empresas listadas na Bolsa de Valores de São Paulo, no ano de 2016. Identificou-se agrupamentos de indicadores baseado em fatores e seus parâmetros de discriminação foram estimados. Concluiu-se que alguns indicadores bem conhecidos não expressam o comportamento geral das organizações, que o parâmetro de discriminação do item é uma importante medida para selecionar indicadores que expressam adequadamente o desempenho da rentabilidade, endividamento, liquidez e caixa, atividades, custo $e$ valor agregado, e crescimento de uma organização.
\end{abstract}

Palavras-chave: Discriminação. Teoria de Resposta ao Item. Indicador de Desempenho Financeiro.

\begin{abstract}
Indicators are well explored to measure business performance, but there are attributes that cannot be easily measured. This work explored the behavior of business indicators using Exploratory Factor Analysis and Item Response Theory. The sample included 203 companies classified on the São Paulo Stock Exchange in 2016. A group of indicators was identified based on factors and the parameter of discrimination of the indicators was estimated. It was concluded that some welldisseminated indicators fail to express the general behavior of the associations well, that the item's discrimination parameter is an important measure to select indicators that express the result of the performance of profitability, indebtedness, liquidity and cash, activities, cost and added value, and growth of an organization.
\end{abstract}

Keywords: Discrimination. Item Response Theory. Financial Performance Indicator

\section{INTRODUÇÃO}

As organizações continuamente procuram mensurar o seu desempenho, utilizando métricas quantitativas. As métricas podem ser representadas através de indicadores que quantificam o resultado (desempenho) de uma atividade e que identificam as lacunas (ALBERTIN, KOHL e ELIAS, 2015).

O uso de métricas é bem explorado no ambiente de negócios para medir o desempenho empresarial, mas alguns atributos não podem ser mensurados diretamente, visto que é um conceito e não uma dimensão física (BAKER, 2001). Entretanto este atributo, chamado de traço latente, pode ser observado nas respostas de um questionário (WILSON, 2004).

Há vários modelos estatísticos utilizados para mensurar o traço latente. Dentre estes estão os que fazem parte da Teoria de Resposta ao Item (TRI).

A TRI aliada a outras técnicas estatísticas, como Análise Fatorial Exploratória foram aplicadas nos últimos anos para, por exemplo, mensurar a interação entre sistemas de informação e usuários (RUSCH et al., 2017), rastreabilidade de produtos (MATZEMBACHER et al., 2018) e para mensurar a associação entre o nível financeiro e bem estar de trabalhadores independentes (PATEL e WOLFE, 2019).

Uma vantagem da utilização da TRI é a possibilidade de explorar parâmetros que não são vistos na teoria clássica dos testes. Dentes estes parâmetros estão a discriminação e dificuldade dos itens, e a maturidade do respondente.

O objetivo deste trabalho é explorar o comportamento de indicadores empresariais utilizando técnicas de Análise Fatorial Exploratória e de Teoria de Resposta ao Item. Enquanto objetivos específicos tem-se:

- Identificar os agrupamentos gerados pela Análise Fatorial Exploratória;

- Mensurar o parâmetro de discriminação de cada indicador dentro do grupo ao qual pertence;

- Discutir a aplicação da técnica para a escolha de indicadores empresariais.

\section{TEORIA DE RESPOSTA AO ITEM E ANÁLISE FATORIAL EXPLORATÓRIA}

Dentre os vários modelos estatísticos da TRI há aqueles onde há mais de dois itens envolvendo um único grupo e com apenas uma habilidade medida. Dentre estes destacam-se o Modelo de Resposta Nominal (BOCK, 1997) e o Modelo de Resposta Gradual (SAMEJIMA, 1969). Este último, diferente do primeiro, assume que as categorias são ordenadas entre si. Um caso particular do Modelo Resposta Gradual de Samejima é o Modelo de Escala Gradual também utilizado para respostas ordenadas (ANDRICH, 1978).O Modelo de Escala Gradual considera que as 
respostas do item são categorizadas, ordenadas e igualmente espaçadas entre si. Neste caso, o modelo apresenta a seguinte fórmula (SAMEJIMA, 1969):

$$
P_{i, k}\left(\theta_{j}\right)=\frac{1}{1+e^{-D a_{i}\left(\theta_{j}-b_{i}+d_{k}\right)}}-\frac{1}{1+e^{-D a_{i}\left(\theta_{j}-b_{i}+d_{k+1}\right)}}
$$

Sendo: $\mathrm{i}=1,2,3, \ldots, p$ (número de itens); $\mathrm{j}=1,2,3$, $\ldots, n$ (tamanho da amostra); $\mathrm{k}_{\mathrm{i}}=0,1,2, \ldots, \mathrm{m}_{\mathrm{i}}$ representando as $m_{i}+1$ categorias de respostas do i-ésimo item; $a_{i}$ é o parâmetro de discriminação do item $\mathrm{i} ; b_{i k i}$ é o parâmetro que representa a dificuldade de estar na ki-ésima categoria do item i, medido na mesma escala da maturidade; $P_{i, k}^{+}$é a probabilidade do indivíduo $\mathrm{j}$ escolher uma particular categoria do item $i$.

A existência de uma ordenação entre os níveis de dificuldade das categorias de determinado item é necessária, ou seja, $b_{i, 1} \leq b_{i, 2} \leq \ldots \leq b_{i, m i}$. A probabilidade do indivíduo $\mathrm{j}$ receber um escore $\mathrm{k}$ no item i é dada por:

$$
P_{i, k}\left(\theta_{j}\right)=P_{i, k}^{+}\left(\theta_{j}\right)-P_{i, k+1}^{+}\left(\theta_{j}\right)
$$

Samejima (1969), define também que:

$$
\begin{aligned}
& P_{i, 0}\left(\theta_{j}\right)=1 \\
& P_{i, m_{i}+1}^{+}\left(\theta_{j}\right)=0 \\
& P_{i, 0}\left(\theta_{j}\right)=P_{i, 0}^{+}\left(\theta_{j}\right)-P_{i, 1}^{+}\left(\theta_{j}\right)=1-P_{i, 1}^{+}\left(\theta_{j}\right) \\
& P_{i, m}\left(\theta_{j}\right)=P_{i, m}^{+}\left(\theta_{j}\right)-P_{i, m_{1}+1}^{+}\left(\theta_{j}\right)=P_{i, m}^{+}\left(\theta_{j}\right)
\end{aligned}
$$

Neste modelo, além do parâmetro de discriminação ou inclinação $\left(a_{i}\right)$, em um item com $\left(m_{i}+1\right)$ categorias, é necessário estimar $\mathrm{m}_{i}$ valores de dificuldade.

Uma das primeiras pesquisas que aplicou a TRI na área de gestão visou analisar um construto construído para mensurar o nível de aplicação de práticas da Gestão pela Qualidade Total (GQT). Inicialmente composto por itens politômicos, os itens foram ressignificados para dicotômicos indicando se aplica ou não determinada prática da GQT. Os autores concluíram que a TRI é uma ferramenta útil para análise de práticas de GQT e de maturidade organizacional (ALEXANDRE et al., 2002).

Outro trabalho na área de gestão com a aplicação da TRI foi desenvolvido para avaliar a diferença da performance e o gerenciamento estratégico entre organizações de serviços sem fins lucrativos e com fins lucrativos (REEVES e FORD, 2004). Neste estudo foi aplicado a TRI, especificamente o modelo de Rasch (BAKER, 2001; RASCH, 1960) para estimar a capacidade estratégica destas organizações. Os autores obtiveram um bom desempenho do modelo ao utilizar a TRI, com ajuste do modelo próximo do ideal.

Albertin et al. (2016) compararam o desempenho de 177 empresas brasileiras, associadas a 18 cadeias produtivas, baseado-se em 46 itens relativos às práticas de excelência em gestão (ALBERTIN et al., 2016). Aplicou-se o modelo de Samejima (SAMEJIMA, 1969) no itens em escala de Likert. A aplicação da técnica se mostrou adequada para identificar o setor benchmark e a identificação das maiores dificuldades na aplicação das práticas logísticas nas empresas pesquisadas.

Pacheco, Andrade e Bornia (2015) propuseram um método que combina a TRI com as etapas do processo de benchmarking com a finalidade de medir a competitividade de produtos por meio de características latentes. Aplicaram este novo método em 1581 cursos e concluíram que com a aplicação da TRI é possível construir escalas para identificar a importância dos itens - no caso as boas práticas - e a dificuldade de inserção desta prática em seus produtos.

Outra técnica estatística que pode ser utilizada em associação com a TRI é a Análise Fatorial Esploratória. Esta técnica estatística que tem o propósito de definir estruturas não observáveis diretamente entre as variáveis analisadas (HAIR et al., 2014). A análise fatorial é classificada como técnica multivariada na qual é possível trabalhar com diversas variáveis, ultrapassando, portanto, a limitação das técnicas univariadas.

Um resultado primário da análise fatorial é definir um conjunto de variáveis que estão altamente relacionadas entre si formando os fatores (HAIR et al., 2014). A determinação da quantidade de fatores está ligada à quantidade de variação contabilizada por um fator. A esta quantidade de variação dá-se o nome de autovalor (originalmente eigenvalues).

\section{PROCEDIMENTOS}

Para alcançar os resultados pretendidos, foram seguidos os seguintes passos: (i) Identificação dos indicadores econômico-financeiro mais disseminados; (ii) Análise da dificuldade de obtenção de dados para elaboração dos indicadores; (iii) Seleção dos indicadores por disseminação e abrangência de empresas; (iv) Análise exploratória dos indicadores. Este passos foram utilizados por Baltazar, Albertin e Pontes (2021, no prelo).

No passo 1 foram identificados os indicadores econômico-financeiro mais disseminados por (a) revistas com publicações econômico-financeiras, (b) sistema de benchmarking europeu Benchmarkingindex $®$, (c) prêmios de qualidade nacionais e (d) organizações de apoio empresarial no Brasil.

No passo 2 analisou-se a dificuldade de obtenção de dados para elaboração dos indicadores. Coletou-se os dados empresariais nos sites das empresas com ações vendidas na Bolsa de Valores de São Paulo e seus relatórios de administração. Esta atividade foi apropriada para identificar a possibilidade de obtenção dos indicadores mais disseminados (encontrados na etapa anterior) ou obtenção dos dados para composição dos indicadores.

No passo 3 foram selecionados os indicadores por disseminação e abrangência de empresas. Incluiu-se neste passo a uniformização do nome do indicador visto que se encontrou nomes similares para o mesmo indicador e a possibilidade de comparação entre mais de uma fonte dos indicadores, ou utilizado pelo Benchmarkingindex®.

A amostra aplicada para esta pesquisa contou com 203 empresas listadas na Bolsa de Valores de São Paulo, no ano de 2016. O quantitativo de empresas por setor de atuação estão assim distribuídos: Transporte e Logística (46), Energia Elétrica (35), Construção Civil (15), Máquinas e Equipamentos (14), Comércio (13), Metalurgia e Siderurgia (12), Têxtil e Vestuário (11), Saneamento (9), Alimentos (8), Comunicação e Informática (6), Petroquímico e Borracha (4), Serviços Médicos (4), Telecomunicações (4), 
Farmacêutico e Higiene (4), Papel e celulose (4), Brinquedos e Lazer (3), Agricultura (2), Educação (2), Extração Mineral (2), Petróleo e Gás (2), Gráfica (1), Hospedagem (1), Bebidas e Fumo (1).

No passo 4 realizou-se a análise exploratória dos indicadores. Para isto, os indicadores foram: (i) transformados em quartis, de maneira que o quarto quartil represente os $25 \%$ melhores desempenho do indicador, enquanto o primeiro quartil represente $25 \%$ dos piores desempenho daquele indicador; (ii) submetidos a testes para identificar a adequabilidade da aplicação da análise fatorial, o qual deve apresentar valores superiores a 0,5 , no geral e individualmente (HAIR et al., 2014, p. 91); (iii) identificação a unidimensionalidade dos indicadores ou a quantidade de fatores. A unidimensionalidade é necessária para realizar a análise com a técnica TRI (McLEOD, SWYGERT, \& THISSEN, 2001). Para determinar o número de fatores foi utilizado o pacote $p s y c h$; (iv) mensuração dos itens mais discriminantes de cada fator encontrado. Para isto, utilizou-se o pacote MIRT (CHALMERS, 2012) para aplicar o modelo de escala gradual (SAMEJIMA, 1969).

\section{RESULTADOS}

\section{1 - Indicadores bem disseminados e adequação da amostragem}

Após a sequência de passos 1, 2 e 3, informado nos procedimentos, chegou-se a um total de 31 indicadores, explorados pelas revistas, órgãos de apoio empresarial e prêmios de qualidade: Exame, Valor Econômico, IstoÉ Dinheiro, Prêmio Nacional da Inovação, Prêmio Brasil MPE, Serviço Brasileiro de Apoio às Micro e Pequenas Empresas (SEBRAE), Federação das Indústrias do Estado do Ceará (FIEC) e Organização das Cooperativas Brasileiras do Estado do Ceará (OCB/CE). Os indicadores podem ser visualizados no Quadro 1. Estes indicadores foram classificados como bem disseminados e com boa abrangência para comparação entre várias organizações e, portanto, foram utilizados para a realização da análise exploratória (passo 4).

No Quadro 1, encontra-se também a medida de adequação da amostragem, do inglês Measure of Sample Adequacy (MSA), de cada indicador selecionado. Esta medida é utilizada para identificar a adequabilidade da aplicação da análise fatorial (HAIR et al., 2014). O valor de MSA dos 31 indicadores foi de 0,81 .

Observa-se valores individuais de MSA, em sua maioria, com valores acima de 0,8, o que indicam boa adequação para aplicação de técnicas de análise fatorial (HAIR et al., 2014).

Os seguintes indicadores apresentaram MSA igual ou inferior a 0,75 :

- Aumentos de Custo de Pessoal (CCPESS);

- Custos de Recursos Humanos / faturamento (ECURHFA);

- Valor agregado / faturamento (\%) (ECUVAFA);

- Rentabilidade do Ativo Líquido (ERONA);

- Prazo Médio de Recebimentos (FAPMRE);

- Valor Ponderado de Grandeza (FGVPG);

- Liquidez Geral (Exame) (FLGER);

- Ativo líquido (caixa) / faturamento (FRALFAT);
Embora não haja um valor limite mínimo para adequação, estes indicadores apresentarão comportamentos de inadequação nas etapas seguintes.

Quadro 1 - Indicadores Selecionados de Acordo com Critério de Disseminação e Facilidade de Obtenção

\begin{tabular}{c|c|c}
\hline Código & MSA & Descrição do Indicador \\
\hline CCPESS & 0,68 & Aumento do custo de pessoal (\%) \\
\hline CEBIT & 0,78 & $\begin{array}{c}\text { Aumento do lucro antes do } \\
\text { imposto e taxas (\%) }\end{array}$ \\
\hline CEBITDA & 0,81 & $\begin{array}{c}\text { Crescimento (ou variação) do } \\
\text { EBITDA }\end{array}$ \\
\hline CLUCRO & 0,80 & Variação de lucro (\%) \\
\hline CVENDAS & 0,79 & Crescimento das Vendas (\%) \\
\hline ECEBIT & 0,80 & $\begin{array}{c}\text { Cobertura de juros (EBIT sobre } \\
\text { juros) }\end{array}$ \\
\hline ECEBITDA & 0,81 & $\begin{array}{c}\text { Cobertura de juros (EBITDA } \\
\text { sobre juros) }\end{array}$ \\
\hline
\end{tabular}

\begin{tabular}{l|l|l}
\hline ECURHFA & 0,52 & Custos de Recursos Humanos /
\end{tabular}

\begin{tabular}{c|c|c} 
& & faturamento (\%) \\
\hline ECUVAFA & 0,74 & Valor agregado / faturamento (\%) \\
\hline EMEBITDA & 0,84 & Margem EBITDA (\%) \\
\hline EREBIT & 0,86 & $\begin{array}{c}\text { Rentabilidade das Vendas (lucro } \\
\text { antes dos impostos e taxas) }\end{array}$ \\
\hline EROA & 0,83 & $\begin{array}{c}\text { Rentabilidade do Ativo (\%) (do } \\
\text { inglês ROA) }\end{array}$
\end{tabular}

\begin{tabular}{c|c|c}
\hline EROCE & 0,84 & $\begin{array}{c}\text { Rentabilidade do Capital } \\
\text { Investido (\%) (do inglês ROCE) }\end{array}$ \\
\hline EROE & 0,84 & $\begin{array}{c}\text { Rentabilidade do Patrimônio } \\
\text { Líquido (\%) (do inglês ROE) }\end{array}$ \\
\hline ERONA & 0,70 & $\begin{array}{c}\text { Rentabilidade do Ativo Líquido } \\
(\%)(\text { do inglês RONA) }\end{array}$
\end{tabular}

\begin{tabular}{c|c|c}
\hline EROTA & 0,87 & $\begin{array}{c}\text { Rentabilidade do Ativo Total (\%) } \\
\text { (do inglês ROTA) }\end{array}$ \\
\hline ERVEN & 0,84 & $\begin{array}{c}\text { Rentabilidade das Vendas (lucro } \\
\text { líquido) }\end{array}$
\end{tabular}

\begin{tabular}{c|cc}
\hline FAPMPA & 0,82 & Prazo Médio de Pagamento (dias) \\
\hline FAPMRE & 0,75 & $\begin{array}{c}\text { Prazo Médio de Recebimentos } \\
\text { (dias, *) }\end{array}$ \\
\hline FEBITDA & 0,77 & EBITDA \\
\hline FEGER & 0,81 & Endividamento geral (\%) \\
\hline FEGRAU & 0,86 & Grau de Endividamento \\
\hline FELPRA & 0,77 & $\begin{array}{c}\text { Endividamento de longo prazo } \\
(\%)\end{array}$ \\
\hline FGVPG & 0,74 & Valor Ponderado de Grandeza \\
\hline FLCOR & 0,82 & Liquidez Corrente \\
\hline FLGER & 0,74 & Liquidez Geral (Exame) \\
\hline FLIME & 0,78 & $\begin{array}{c}\text { Índice de liquidez imediata (teste } \\
\text { ácido) (\%) }\end{array}$ \\
\hline FRALFAT & 0,75 & $\begin{array}{c}\text { Ativo líquido (caixa) / } \\
\text { faturamento (\%) }\end{array}$ \\
\hline FRCCLI & 0,83 & Capital circulante líquido \\
\hline FRCGIR & 0,85 & Capital de giro \\
\hline FRGCTR & 0,82 & $\begin{array}{c}\text { Giro de capital de trabalho } \\
\text { (working capital turnover) }\end{array}$ \\
\hline
\end{tabular}


4.2 - Análise Fatorial Exploratória e agrupamentos dos indicadores

Continuando a análise dos indicadores, foi utilizada a técnica estatística Análise Fatorial Exploratória. Utilizou-se como ferramenta o pacote psych (REVELLE, 2018), interpretado na linguagem R (THE R FOUNDATION, 2018), para calcular a quantidade de fatores e agrupar os indicadores de acordo com as cargas fatoriais.

Assim, identificou-se 5 fatores que apresentaram autovalores superiores a 1. Aplicou-se um filtro para exibir apenas os valores de carga fatorial superior a 0,3. Os resultados podem ser visualizados na Tabela 1.

Tabela 1 - Cargas Fatoriais Superior a 0.3 para 5 Fatores

\begin{tabular}{|c|c|c|c|c|c|}
\hline Indicador & $\begin{array}{c}\text { Fator } \\
1 \\
\end{array}$ & $\begin{array}{c}\text { Fator } \\
2 \\
\end{array}$ & $\begin{array}{c}\text { Fator } \\
\mathbf{3} \\
\end{array}$ & $\begin{array}{c}\text { Fator } \\
4 \\
\end{array}$ & $\begin{array}{c}\text { Fator } \\
5 \\
\end{array}$ \\
\hline ERVEN & $\mathbf{0 , 8 0}$ & & & & \\
\hline EREBIT & 0,71 & & & & \\
\hline EROCE & 0,66 & 0,34 & & & \\
\hline EROTA & 0,74 & & & & \\
\hline EMEBITDA & $\mathbf{0 , 5 3}$ & & & 0,41 & \\
\hline EROE & 0,72 & & & & \\
\hline ECEBIT & 0,76 & & & & \\
\hline ECEBITDA & $\mathbf{0 , 8 3}$ & & & & \\
\hline FEBITDA & 0,35 & $\mathbf{0 , 7 0}$ & & & \\
\hline EROA & & 0,34 & & & \\
\hline FEGRAU & & 0,76 & & & \\
\hline FGVPG & & $\mathbf{0 , 7 3}$ & & & \\
\hline FEGER & & 0,69 & & & \\
\hline FELPRA & & 0,54 & & & \\
\hline FRCGIR & & 0,44 & 0,33 & & \\
\hline FLGER & & 0,57 & & 0,32 & \\
\hline FRCCLI & & & 0,95 & & \\
\hline FLCOR & & & $\mathbf{0 , 9 3}$ & & \\
\hline FLIME & & & $\mathbf{0 , 8 4}$ & & \\
\hline FRGCTR & & & 0,77 & & \\
\hline FRALFAT & & & 0,34 & & \\
\hline ECURHFA & & & & 0,67 & \\
\hline ECUVAFA & & & & 0,39 & \\
\hline FAPMPA & & & 0,30 & 0,62 & \\
\hline FAPMRE & & & & 0,66 & \\
\hline CEBITDA & & & & & 0,79 \\
\hline CLUCRO & & & & & 0,75 \\
\hline CEBIT & & & & & $\mathbf{0 , 8 7}$ \\
\hline CVENDAS & & & & & 0,48 \\
\hline \multicolumn{6}{|l|}{ CCPESS } \\
\hline ERONA & & & & & \\
\hline
\end{tabular}

É possível visualizar que os agrupamentos - ou fatores - seguiram uma lógica conceitual para a maioria dos indicadores. Estes fatores podem ser nomeados em Rentabilidade (Fator 1), Atividades, Custo e Valor Agregado (Fator 2), Endividamento (Fator 3), Liquidez e Caixa (Fator 4) e Crescimento (Fator 5).
Alguns indicadores não apresentaram carga fatorial superior a $0,3 \mathrm{em}$ nenhuma dos fatores. Foram estes:

- Aumento do Custo de Pessoal (CCPESS); e

- Rentabilidade do Ativo Líquido (\%) (ERONA).

Nota-se também que alguns indicadores apresentaram carga fatorial superior a $0,3 \mathrm{em}$ mais de um fator, informados a seguir:

- Rentabilidade do Capital Investido (\%) (EROCE): Rentabilidade e Endividamento;

- Margem EBITDA (EMEBITDA): Rentabilidade, e Liquidez e Caixa;

- EBITDA (FEBITDA): Rentabilidade e Endividamento;

- Capital de Giro (FRCGIR): Atividades, Custo e Valor Agregado, e Endividamento;

- Liquidez Geral (Exame) (FLGER): Atividade, Custo e valor, e Liquidez e Caixa;

- Prazo Médio de Pagamento (dias) (FAPMPA): Endividamento, e Liquidez e Caixa.

Estes indicadores foram agrupados onde apresentavam maior carga fatorial.

Constata-se que os indicadores que apresentaram o MSA inferior ou igual a 0,7 não obtiveram carga fatorial suficiente para participar de nenhum fator. Isto sugere que a métrica MSA foi útil para prever falhas nos agrupamentos destes indicadores.

Entretanto, a métrica MSA não conseguiu prever com exatidão que indicadores poderiam ter carga fatorial acima de 0,3 em mais de um fator. Isto pois 4 dos 6 indicadores nesta situação, tinha valores MSA superiores a 0,82 .

\section{3 - Análise de discriminação dos indicadores}

Após o agrupamento por carga fatorial, foi calculado o nível de discriminação de cada indicador, no seu respectivo grupo. Utilizou-se a Teoria de Resposta ao Item, mais especificamente o Modelo de Escala Gradual de Samejima. O resultado é apresentado no Quadro 2.

Os valores de discriminação geralmente apresentam valores entre -3 a 3 , embora seja uma escala arbitrária. Valores altos e positivos de discriminação significam que uma organização que apresenta um bom desempenho neste indicador se destaca por um bom desempenho da empresa em outros indicadores do mesmo grupo. Assim, observa-se que uma organização que apresentar alta Rentabilidade das Vendas (ERVEN) estará fortemente associada a um bom desempenho geral em outros indicadores de rentabilidade.

Embora a discriminação da Margem EBITDA (MEBITDA) ainda seja forte $(1,8)$, em comparação com Rentabilidade das Vendas (ERVEN), este é preferível àquele. Então, é possível criar uma lista de predileção de indicadores de rentabilidade, onde: ERVEN > EROE > ECEBITDA > EREBIT $>$ ECEBIT $>$ EROTA $>$ EROCE > EMEBITDA.

Seguindo o mesmo raciocínio, no agrupamento Atividades, Custo e Valor Agregado, um bom desempenho em Prazo Médio de Pagamento (dias) (FAPMPA) não significa exatamente que a organização tenha um bom desempenho em outros indicadores, ou seja, não está associada com um bom desempenho geral neste grupo.

Assim, partindo do Quadro 2, é possível selecionar indicadores que melhor representem o desempenho geral de uma organização, levando em consideração o valor de 
discrminiação deste indicador em relação ao grupo ao qual pertence. De forma mais detalhada, é possível usar o parâmetro para selecionar indicadores que tem uma formulação similar, mas que tenha um nível maior de discriminação. Um exemplo prático é a preferência pela utilização da Cobertura de juros (EBITDA sobre juros) (ECEBITDA), que apresenta discriminação 3,0 no lugar de Margem EBITDA (\%) (MEBITDA) que apresenta discriminação 1,8 ou no lugar de EBITDA (FEBITDA) que apresenta discriminação $-2,8$.

Outro comportamento identificado é a presença de valores discrepantes. Observa-se isto nos indicadores:

- Aumento do lucro antes do imposto e taxas (\%) (CEBIT): 11,1

- Liquidez Corrente (FLICOR): 9,8;

- Rentabilidade das Vendas (lucro líquido): 5,3.

Estes valores naturalmente representariam que estes indicadores pertencem a outros fatores, entretanto esta hipótese foi descartada com o cálculo da carga fatorial. Cabe, assim, investigar o motivo deste comportamento.

Quadro 2 - Relação de Indicadores por grupo e por Ordem Decrescente de Discriminação

\begin{tabular}{|c|c|c|c|}
\hline Grupo & Código & Indicador & $\begin{array}{l}\text { Discrimi } \\
\text { nação }\end{array}$ \\
\hline \multirow{8}{*}{ 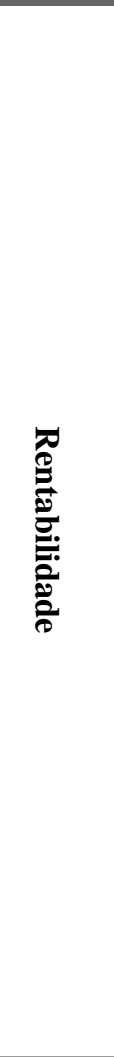 } & ERVEN & $\begin{array}{l}\text { Rentabilidade das } \\
\text { Vendas (lucro } \\
\text { líquido) }\end{array}$ & 5,3 \\
\hline & EROE & $\begin{array}{l}\text { Rentabilidade do } \\
\text { Patrimônio } \\
\text { Líquido (\%) (do } \\
\text { inglês ROE) }\end{array}$ & 3,8 \\
\hline & ECEBITDA & $\begin{array}{l}\text { Cobertura de } \\
\text { juros (EBITDA } \\
\text { sobre juros) }\end{array}$ & 3,0 \\
\hline & EREBIT & $\begin{array}{l}\text { Rentabilidade das } \\
\text { Vendas (lucro } \\
\text { antes dos } \\
\text { impostos e taxas) }\end{array}$ & 3,0 \\
\hline & ECEBIT & $\begin{array}{l}\text { Cobertura de } \\
\text { juros (EBIT sobre } \\
\text { juros) }\end{array}$ & 2,9 \\
\hline & EROTA & $\begin{array}{l}\text { Rentabilidade do } \\
\text { Ativo Total (\%) } \\
\text { (do inglês ROTA) }\end{array}$ & 2,7 \\
\hline & EROCE & $\begin{array}{l}\text { Rentabilidade do } \\
\text { Capital Investido } \\
\text { (\%) (do inglês } \\
\text { ROCE) }\end{array}$ & 2,4 \\
\hline & EMEBITDA & $\begin{array}{l}\text { Margem EBITDA } \\
(\%)\end{array}$ & 1,8 \\
\hline \multirow{6}{*}{ 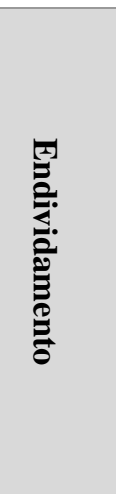 } & FEGER & $\begin{array}{l}\text { Endividamento } \\
\text { geral }(\%)\end{array}$ & 2,9 \\
\hline & FEGRAU & $\begin{array}{l}\text { Grau de } \\
\text { Endividamento }\end{array}$ & 2,6 \\
\hline & FRCGIR & Capital de giro & 1,6 \\
\hline & FELPRA & $\begin{array}{l}\text { Endividamento de } \\
\text { longo prazo }(\%)\end{array}$ & 1,1 \\
\hline & FLGER & $\begin{array}{l}\text { Liquidez Geral } \\
\text { (Exame) }\end{array}$ & 0,9 \\
\hline & EROA & $\begin{array}{l}\text { Rentabilidade do } \\
\text { Ativo (\%) (do } \\
\text { inglês ROA) }\end{array}$ & $-0,7$ \\
\hline
\end{tabular}

\begin{tabular}{|c|c|c|c|}
\hline Grupo & Código & Indicador & $\begin{array}{c}\text { Discrimi } \\
\text { nação }\end{array}$ \\
\hline & FEBITDA & EBITDA & $-2,8$ \\
\hline & FGVPG & $\begin{array}{l}\text { Valor Ponderado } \\
\text { de Grandeza }\end{array}$ & $-3,0$ \\
\hline \multirow{5}{*}{ 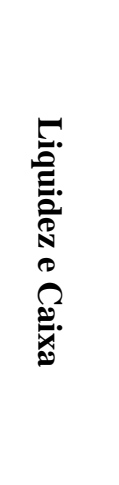 } & FLCOR & Liquidez Corrente & 9,8 \\
\hline & FLIME & $\begin{array}{l}\text { Índice de liquidez } \\
\text { imediata (teste } \\
\text { ácido) }(\%)\end{array}$ & 4,7 \\
\hline & FRCCLI & $\begin{array}{l}\text { Capital circulante } \\
\text { líquido }\end{array}$ & 4,5 \\
\hline & FRGCTR & $\begin{array}{l}\text { Giro de capital de } \\
\text { trabalho (working } \\
\text { capital turnover) }\end{array}$ & 1,8 \\
\hline & FRALFAT & $\begin{array}{l}\text { Ativo líquido } \\
\text { (caixa) / } \\
\text { faturamento }(\%)\end{array}$ & 0,6 \\
\hline \multirow{4}{*}{ 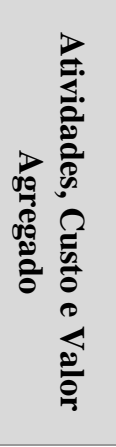 } & FAPMRE & $\begin{array}{l}\text { Prazo Médio de } \\
\text { Recebimentos } \\
\left(\text { dias, }{ }^{*}\right)\end{array}$ & 2,9 \\
\hline & ECURHFA & $\begin{array}{l}\text { Custos de } \\
\text { Recursos } \\
\text { Humanos / } \\
\text { faturamento (\%) }\end{array}$ & 1,7 \\
\hline & ECUVAFA & $\begin{array}{l}\text { Valor agregado / } \\
\text { faturamento }(\%)\end{array}$ & $-1,6$ \\
\hline & FAPMPA & $\begin{array}{l}\text { Prazo Médio de } \\
\text { Pagamento (dias) }\end{array}$ & $-1,8$ \\
\hline \multirow{4}{*}{ 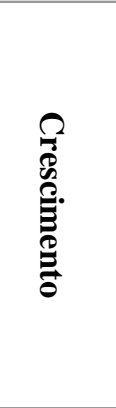 } & CEBIT & $\begin{array}{l}\text { Aumento do lucro } \\
\text { antes do imposto } \\
\text { e taxas }(\%)\end{array}$ & 11,1 \\
\hline & CLUCRO & $\begin{array}{l}\text { Variação de lucro } \\
(\%)\end{array}$ & 3,0 \\
\hline & CEBITDA & $\begin{array}{l}\text { Crescimento (ou } \\
\text { variação) do } \\
\text { EBITDA }\end{array}$ & 3,0 \\
\hline & CVENDAS & $\begin{array}{l}\text { Crescimento das } \\
\text { Vendas (\%) }\end{array}$ & 1,2 \\
\hline
\end{tabular}

Fonte: Elaborado pelos autores, 2020.

\section{CONCLUSÃO}

As técnicas Análise Fatorial Exploratória e Teoria de Resposta ao Item foram aplicadas no grupo de indicadores empresariais bem disseminados e de fácil acesso. Com isto, foi possível identificar o comportamento destes indicadores.

Conclui-se que alguns indicadores empresariais bem disseminados não conseguem expressar muito bem o comportamento geral das organizações. Assim, estes indicadores podem ser substituídos por outros que apresentam maiores nível de discriminação.

Identificou-se também que indicadores similares na sua formulação podem divergir no nível de discriminação dos indicadores. Pelas análises realizadas por este projeto, pode-se sugerir que há um nível de predileção quanto a indicadores que utilizam o EBITDA em sua formulação como Cobertura de juros (EBITDA sobre juros) > Margem EBITDA (\%) > EBITDA, ou que utilizam lucro Rentabilidade das Vendas (lucro líquido) > Rentabilidade das Vendas (lucro antes dos impostos e taxas).

Quanto a utilização da medida de adequação da amostra, conclui-se que é uma métrica importante para detecção de problemas nos agrupamentos de indicadores. 
Em contrapartida, ele não consegue prever indicadores com carga fatorial elevada em mais de um fator.

Concluiu-se também que o parâmetro de discriminação do item é uma importante medida para selecionar indicadores que expressam adequadamente o desempenho da rentabilidade, endividamento, liquidez e caixa, atividades, custo e valor agregado, e crescimento de uma organização.

Como sugestões de trabalhos estão: identificar o motivo do comportamento divergente dos indicadores Aumento do Custo de Pessoal (\%) e Rentabilidade do Ativo Líquido (\%) (do inglês RONA) que não se enquadraram em nenhum dos fatores identificados e replicar este estudo para analisar se os indicadores apresentam o mesmo comportamento quanto aos agrupamentos e valores de discriminação.

O presente estudo apresenta limitações quanto ao período aplicado e às empresas participantes, visto que foram selecionadas apenas as empresas listadas na Bolsa de Valores de São Paulo do ano de 2016. Outra limitação se refere à análise apenas do parâmetro de discriminação do item.

\section{REFERÊNCIAS}

ALBERTIN, M. R. et al. Benchmarking de práticas de excelência através da teoria da resposta ao item. Revista de Administração, Contabilidade e Economia da Fundace, v. 7, n. 2, 19 maio 2016.

ALBERTIN, M. R.; KOHL, H.; ELIAS, S. J. B. Manual do Benchmarking. Fortaleza: Imprensa Universitária, 2015.

ALEXANDRE, J. W. C. et al. Uma proposta de análise de um construto para medição dos fatores críticos da gestão pela qualidade por intermédio da Teoria da Resposta ao Item. Gestão \& Produção, v.9, n.2, p.129-141, ago. 2002.

ANDRICH, D. A rating formulation for ordered response categories. Psychometrika, v. 43, n. 7, p. 561-573, 1978.

BAKER, F. B. The Basics of Item Response Theory. Second Edition. Second Edi ed. [s.l.] ERIC Clearinghouse on Assessmente and Evaluation, 2001.

BALTAZAR, M. C. P.; ALBERTIN, M. R.; PONTES, H. L. J. Aplicação da Teoria de Resposta ao Item (TRI) na identificação de indicadores quantitativos discriminantes para a prática de benchmarking empresarial. EXACTA (ONLINE), v. 19, n. 4, 2021.

BOCK, R. . A brief history of item theory response. Educational Measurement: Issues and Practice, v. 16, n. 4, p. 21-23, 1997.

HAIR, J. F. et al. Multivariate Data Analysis: Pearson New International Edition. 7. ed. [s.1.] Atlas, 2014.

MATZEMBACHER, D. E. et al. An integration of traceability elements and their impact in consumer's trust. Food Control, v. 92, n. May, p. 420-429, 2018.

PACHECO, J.; ANDRADE, D. DE; BORNIA, A. Benchmarking by Item Response Theory (BIRTH): A benchmarking method using IRT to build competitiveness scales for Brazilian technology higher education. Benchmarking: An International Journal, v. 22, n. 5, p. 945-962, 2015.
PATEL, P. C.; WOLFE, M. T. Money might not make you happy, but can happiness make you money? The value of leveraging subjective well-being to enhance financial wellbeing in self-employment. Journal of Business Venturing Insights, v. 12, n. June, p. e00134, 2019.

RASCH, G. Probabilistic Models for Some Intelligence and Attainment Tests. Copenhagem: The Danish Institute of Educational Research, 1960.

REEVES, T. C.; FORD, E. W. Strategic Management and Performance Differences. Health Care Management Review, v. 29, n. 4, p. 298-308, out. 2004.

REVELLE, W. psych: Procedures for Psychological, Psychometric, and Personality ResearchEvanstonNorthwestern University, , 2018. Disponível em: 〈https://cran.r-project.org/package=psych>

RUSCH, T. et al. Breaking free from the limitations of classical test theory: Developing and measuring information systems scales using item response theory. Information and Management, v. 54, n. 2, p. 189-203, 2017.

SAMEJIMA, F. Estimation of latent ability using a response pattern of graded scores. Psychometrika, v. 1, n. 17, p. 1 $100,1969$.

THE R FOUNDATION. The R Project for Statistical Computing. Disponível em: <http://www.r-project.org/>. Acesso em: 15 dez. 2019.

WILSON, M. Constructing measures: An item response modeling approach. [s.1.] Routledge, 2004.

\section{COPYRIGHT}

Direitos autorais: Os autores são os únicos responsáveis pelo material incluído no artigo.

Submetido em: 10/09/2020

Aprovado em: 26/09/2020 